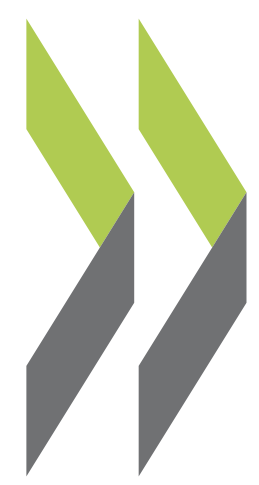

OECD Economics Department Working Papers No. 132

\author{
High and Persistent \\ Unemployment:
}

Assessment of the Problem

\title{
Jørgen Elmeskov
}

\author{
and Its Causes
}




\title{
ECONOMICS DEPARTMENT
}

WORKING PAPERS

No. 132

\section{HIGH AND PERSISTENT UNEMPLOYMENT: ASSESSMENT OF THE PROBLEM AND ITS CAUSES}

\author{
by \\ Jørgen Elmeskov \\ Resource Allocation Division
}

\section{OECD \\ OCDE}

ORGANISATION FOR ECONOMIC CO-OPERATION AND DEVELOPMENT 
OCDE/GD(93)138

\title{
ECONOMICS DEPARTMENT
}

WORKING PAPERS

NO. 132

\section{HIGH AND PERSISTENT UNEMPLOYMENT: ASSESSMENT OF THE PROBLEM AND ITS CAUSES}

\author{
BY \\ JøRGEN ELMESKOV \\ RESOURCE ALLOCATION DIVISION
}

ORGANISATION FOR ECONOMIC CO-OPERATION AND DEVELOPMENT Paris 1993

007975

COMPLETE DOCUMENT AVAILABLE ON OLIS IN ITS ORIGINAL FORMAT 


\section{HIGH AND PERSISTENT UNEMPLOYMENT: ASSESSMENT OF THE PROBLEM AND ITS CAUSES}

Unemployment has emerged as one of the most pressing economic concerns in the majority of OECD countries. However, experiences differ across countries as regards the level, volatility and composition of unemployment. Nevertheless, a common feature in many countries is that given levels of wage acceleration, capacity utilisation and vacancy rates are now associated with much higher levels of unemployment than used to be the case two decades ago. Countries seem to differ in the extent to which rising trend unemployment reflects a rise in equilibrium unemployment ("the natural rate") or slow adjustment towards an equilibrium level which is lower than trend unemployment. A number of factors can be pointed to as affecting either equilibrium unemployment or the speed of adjustment in labour markets. Such factors comprise both labour market institutions and policies as well as features that are outside the realm of structural policies. A review of the literature as well as the examination of empirical data on a cross-country basis suggest that a number of these factors are unlikely to account for high and persistent unemployment while others have affected countries' unemployment experience to different degrees.

Le chômage est apparu comme l'une des préoccupations les plus pressantes dans la majorité des pays de l'OCDE. Cependant, les expériences different d'un pays a l'autre, en fonction du niveau, de la volatilité et de la composition du chômage. Néanmoins, il se dégage un point commun à bon nombre de pays : des niveaux donnés d'accélération des salaires, d'utilisation des capacités de production et de taux de vacances d'emploi, sont maintenant associés à des niveaux de chômage supérieurs à ceux généralement enregistrés, il y a deux décennies. Des différences semblent apparaître entre les pays dans la mesure où un chômage tendanciel croissant peut reflèter une augmentation du chômage à l'équilibre ("le taux naturel") ou un ralentissement de l'ajustement vers un niveau d'équilibre plus faible que le chômage tendanciel. On peut mettre en évidence un ensemble de facteurs qui affectent soit le chômage à l'équilibre soit la vitesse d'ajustement sur le marché du travail. Cet ensemble comporte a la fois des facteurs liés aux institutions et aux politiques sur le marché du travail, et des caractéristiques trouvées en dehors du domaine des politiques structurelles. Un examen de la littérature et l'analyse de données empiriques inter-pays suggèrent que, pour justifier l'ampleur persistante du chômage certains de ces facteurs sont improbables tandis que d'autres influencent à des degrés divers le chômage dans certains pays. 


\section{Contents}

The Structure of the Paper $\ldots \ldots \ldots \ldots \ldots \ldots \ldots \ldots \ldots \ldots \ldots \ldots \ldots \ldots \ldots \ldots$

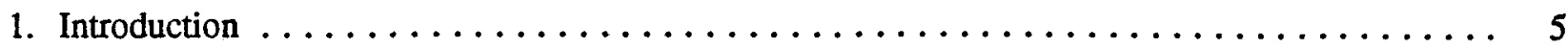

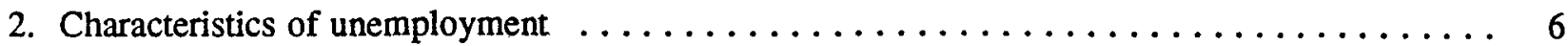

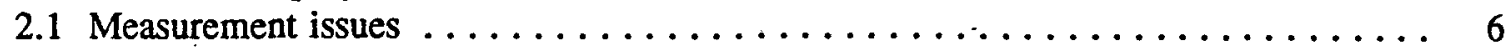

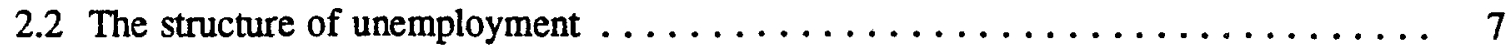

2.3 The dynamics of unemployment (cycle versus trend) $\ldots \ldots \ldots \ldots \ldots \ldots \ldots$. 9

3. Causes of the trend rise in unemployment $\ldots \ldots \ldots \ldots \ldots \ldots \ldots \ldots \ldots \ldots \ldots \ldots \ldots \ldots$

3.1 A conceptual framework . . . . . . . . . . . . . . . . . . . . . 11

3.2 Higher "equilibrium" unemployment or slow labour-market adjustment . . . . . 12

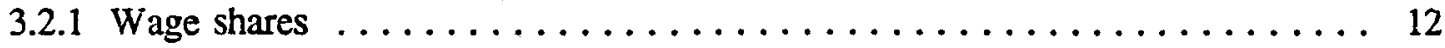

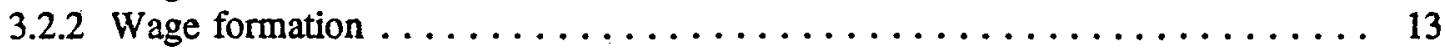

3.3 Possible causes of unemployment outside the area of structural policy . . . . . . 14

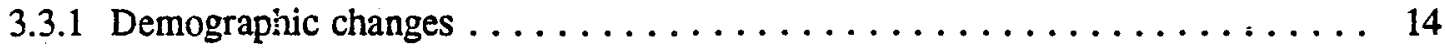

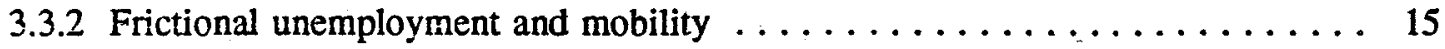

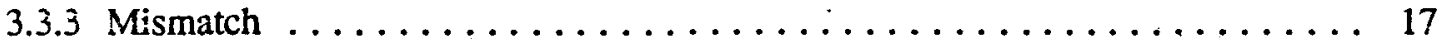

3.3.4 Trade and product market competition $\ldots \ldots \ldots \ldots \ldots \ldots \ldots \ldots \ldots \ldots \ldots$

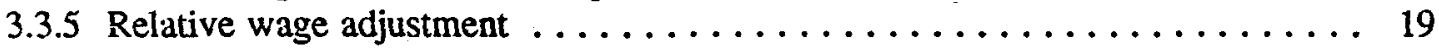

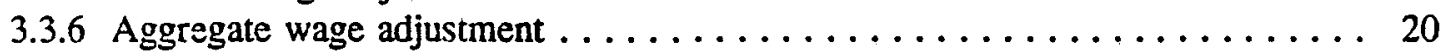

3.3.6.1 Sociai attitudes, union militancy and public-sector wage setting . . . . 20

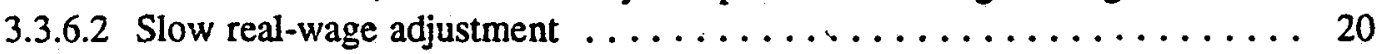

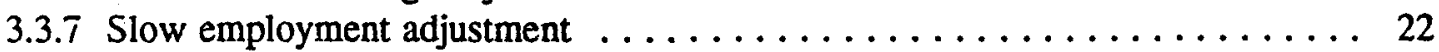

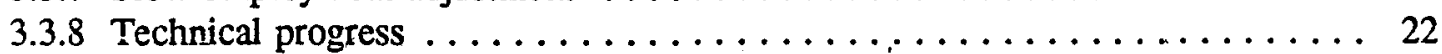

3.3 .9 Budget deficits and high real interest rates $\ldots \ldots \ldots \ldots \ldots \ldots \ldots \ldots$

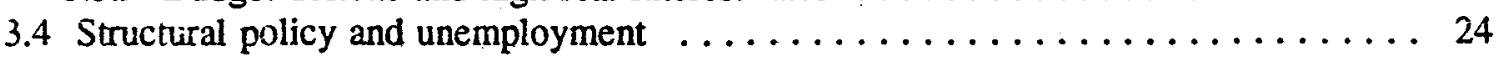

3.4.1 Unemployment benefit systems and other social transfers $\ldots \ldots \ldots \ldots \ldots 24$

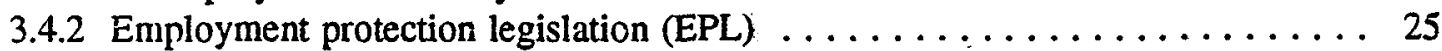

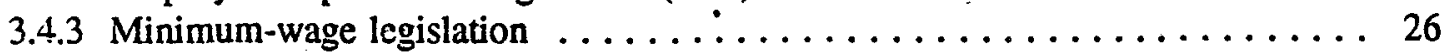

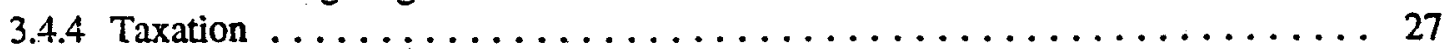

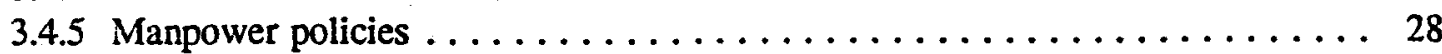

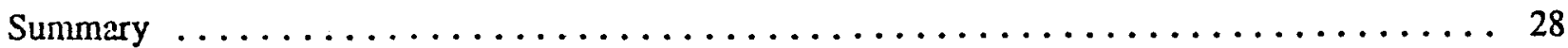

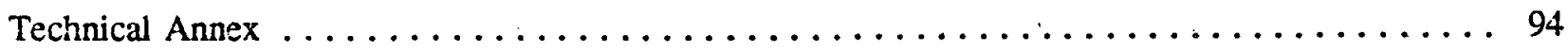

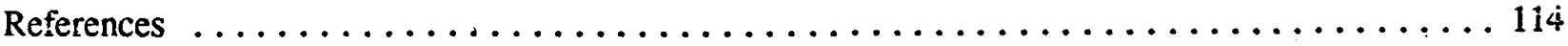




\section{Figures}

1. Unemployment and participation rates

2. Indicators of the trend OECD unemployment rate

3. Actual and trend unemployment

4. Cyclicality and trend rise of unemployment

5. Wage shares in the business sector

6. Real wage and marginal product of labour

7. Impact of demography on the unemployment rate

8. Unemployment rates for certain cohorts relative to total unemployment rate

9. Indicators of sectoral and regional employment change and turbulence

10. Seasonal variations of unemployment rates

11. Short-run real wage rigidity and unemployment increase

12. Real wage rigidity and centralisation of wage bargaining

13. Generosity of unemployment benefit systems and the unemployment rate

14. Average levels of severance payments and of notice periods 1956-84

15. Trends in unemployment rates and annual working hours across countries

16. Relative minimum wage and the relation between youth and prime-age unemployment rates

Tables

1. Unemployment rates

2. Age and gender structure of unemployment

3. Unemployment rates by, level of educational attainment

4. Regional unemployment rates

5. Summary measures of regional unemployment dispersion

6. Inflow to and average duration of unemployment

7. The cyclicality of unemployment

8. Time-series properties of unemployment

9. Testing for the influence of employment on wage formation

10. Impact of job change on unemployment

11. Decomposition of employment growth

12. Indicators of wage dispersion

13. Number of beneficiaries of selected early retirement pensions, 1980-1990

14. Effective tax rates

15. Labour market policies

\section{Technical Annex Tables}

A1. Cohort effects using lagged cohort unemployment

A2. Cobort effects using lagged aggregate unemployment

A3. Impact of friction on unemployment

A4. Causality between public and private sector wages

A5. Granger causality between public and private sector wages

A6. Employment adjustment

Figures

A1. Okun curves and alternative measures of capacity utilisation

A2. Actual and trend unemployment 


\title{
HIGH AND PERSISTENT UNEMPLOYMENT: ASSESSMENT OF THE PROBLEM AND ITS CAUSES
}

\author{
Jørgen Elmeskov ${ }^{1}$
}

The Structure of the Paper

Developments in the labour markets of OECD Member countries over the past two to three decades and their causes are reviewed in this paper. Following the introduction, analysis begins with a summary of measurement issues, affecting the comparability of unemployment rates between countries and over time, and the extent to which increases in measured unemployment represent a decline in the "true" rate of utilisation of human resources. Various aspects of the structure of unemployment are then discussed. In the subsequent discussion of the evolution of unemployment over time, a distinction is made between cyclical and trend, or non-cyclical, components of observed unemployment. The trend rate of unemployment has increased in most countries and the question is asked as to whether this represents an increase in the "normal" or "equilibrium" rate of unemployment. This hypothesis is tested against the view that, following an increase, unemployment returns only slowly to its equilibrium rate, implying persistent disequilibrium in labour markets. The paper then reviews a large number of possible causes for the trend increase in unemployment. In doing so, a distinction is made between policy and non-policy influences, and their effects on both equilibrium unemployment and labour-market adjustment speeds.

\section{Introduction}

Total OECD unemployment increased markedly between the mid-1960s and the early 1980 s, rising from a rate of 2.5. per cent in 1966 to a peak of 8.6 per cent in 1983 (Figure 1). Most of the overall increase occurred in the aftermath of the two oil price shocks in 1974 and 1979. Unemployment then declined somewhat through the late 1980s, but since 1991 it has been rising again. The average number of persons unemployed is projected to reach almost 36 million ( 8.7 per cent of the total OECD labour force) by the end of 1993. Many more people - a reasonable estimate, given the average length of unemployment spells, may be twice as many -- are unemployed for some period in the course of a year.

Rising unemployment coincided with an increasing trend in the OECD labour force during the 1970s and 1980s. However, differences across countries are pronounced, both in terms of unemployment and labour-force participation. As a general rule, participation rates rose less, or even fell, when and where unemployment rose. The differences in trends and levels of unemployment and participation rates across countries are clearly visible in Figure 1.

In some countries, including the United States, Japan, Austria and, until recently, Iceland, Norway, Sweden and Switzerland, unemployment was either stable or rose very little (Table 1). In these countries, with the exception of the United States, the level of unemployment was also low. In countries where unemployment rose strongly, increases of more than 5 percentage points between the first half of the $1960 \mathrm{~s}$ and second half of the 1980s were recorded in Germany, France, Italy, United Kingdom, Australia, Belgium, Denmark, Ireland, Netherlands, Portugal, Spain and Turkey. In half of the OECD countries, 
unemployment exceeded 10 per cent of the labour force in 1992, with much higher rates recorded in Spain and Ireland.

The growing imbalance in the OECD labour market since 1970 has not been a pure cyclical phenomenon: various proxy measures of the trend rate of unemployment show that the rise in unemployment cannot be explained satisfactorily just by a lack of effective demand: the rate of unemployment needed to stabilise wage inflation (the so-called NAWRU) appears to have risen significantly compared with the 1960s (Figure 2, panel A). Similarly, it seems that the rate of unemployment associated with a given vacancy rate has increased, suggesting that vacant jobs are filled less easily than previously (Figure 2, panel B). Finally, physical production capacity (the capital stock) appears to have developed in a way so that a normal rate of capacity utilisation is now reached with employment much below the available supply of labour (Figure 2, panel C). Translating the developments depicted in panels A, B and $C$ of Figure 2 into alternative trend measures of unemployment, panel $D$ shows that all three proxy measures rose steeply between the early 1970 s and mid-1980s, when they started to decline again ${ }^{2}$.

\section{Characteristics of unemployment}

\subsection{Measurement issues}

Unemployment is a key economic-policy target because of its association with governments' objectives of using labour resources efficiently and reducing social problems and poverty. Moreover, in many countries unemployment involves large direct and indirect budgetary costs. Before setting out to study the development and causes of unemployment, it is worth contemplating whether current unemployment statistics provide a good measure of the various dimensions of the problem. Previous work suggests the following main conclusions ${ }^{3}$ :

-- The working-age population can be partitioned into three principal labour-market states: employed, unemployed or non-participating in the labour force. Different statistical sources give different classifications. For example, administrative files define unemployment in terms of the conditions that make persons eligible for income transfers, while household surveys use job search and availability for work as criteria for unemployment. As a result, measured unemployment rates differ by source.

-- Persons in similar situations may be classified differently in different countries, depending on labour-market institutions, e.g. persons losing their jobs may in some countries choose to be registered as unemployed if that makes them eligible for income transfers, whereas in others they may leave the labour force. Differences may also exist over time in individual countries.

-- Unemployment is an indirect, incomplete and sometimes misleading indicator of social problems and poverty, both within and across countries. Social problems and poverty exist outside the ranks of the unemployed, and not all unemployed necessarily endure economic hardship. To give two examples: what in one country may show up as employed persons working at low wages may in others, because a truncated wage structure prevents lowproductivity workers from having a job, show up as unemployed persons receiving transfer income. And in countries where unemployment compensation is high, a spell of unemployment need not entail economic deprivation.

-- Unemployment is also an imperfect measure of under-utilisation of labour resources. In some countries, aggregate employment figures may be inflated due to so-called "labour hoarding", resulting either because of voluntary private-sector optimising behaviour (e.g. anticipating 
future changes in labour suppiy or demand or expecting efficiency gains from providing job security) or because it is imposed by labour-market regulation. In cases where the labour force responds strongly to cyclical changes in employment, unemployment may change only little when employment -- and thus the utilisation of labour resources -- changes a lot:

-. Countries with high unemployment usually have low participation rates, suggesting that the cross-country pattern of unemployment may give some indication of how countries are ranked with respect to utilisation rates of labour resources; but it does not give a full picture of cross-country differences in this respect. Over time, the number of discouraged workers tends to develop in parallel with unemployment, showing broadly the same cyclical behaviour.

-. As a measure of wage pressure, in most countries unemployment performs better than alternative measures of labour market slack that take into account the cyclical responsiveness of the labour force, though there is evidence that not all categories of unemployed exert the same damping effect on wages ${ }^{4}$.

The imperfections of unemployment as an indicator of the various conditions it purports to measure, as well as the ambiguities of measurement, should be kept in mind when assessing the evidence on unemployment presented below.

\subsection{The structure of unemployment}

Unemployment affects disproportionately young people and, in some countries, women (Table 2). Unemployment rates for young people are typically between two and three times those of adults, with Germany being a notable exception to this "rule", probably reflecting the role of the so-called "dual" system of vocational education and training in the transition of young persons from the school system into the labour market. In most countries, older persons have lower unemployment rates than prime-aged persons ${ }^{5}$. Female unemployment rates are significantly higher than male rates in most continental EC countries, but not elsewhere in the OECD area. There seems to be an inverse relation between group-specific unemployment and participation rates: youth participation is generally lower than adult participation and countries with relatively high female unemployment tend to have relatively low female labour-force participation. However, for older persons the relation is direct, countries with relatively low unemployment among older persons also having relatively low participation rates 5 .

As regards developments over time, age and gender differences in unemployment rates appear to have narrowed over the $1980 \mathrm{~s}$ in most countries. In the case of youth and female unemplcyment, this relative improvement contrasts with some deterioration in the 1970s. Lower relative youth unemployment reflected, inter alia, diminishing size of the young cohorts, a tendency to leave the education system later, and a stepped-up effort in labour-market measures targeted at young persons. Supply changes were also important for older persons, with participation rates falling sharply for older men due, not least, to the increased availability of various labour-market programmes such as early retirement, which were introduced in response to rising overall unemployment. The narrowing of female and male unemployment rates, on the other hand, took place in spite of a pronounced rise in the female participation rate. Relatively high female employment growth appeared to reflect particularly strong growth of employment in sectors of the economies where traditionally female employment dominates rather than an increased "market share" of females within individual sectors. Nevertheless, some of the countries where female unemployment remained considerably higher than male unemployment at the end of the decade, such as Italy, the Netherlands and Spain, had comparatively low female participation rates. 
Unemployment also differs across educational categories and regions. However, in these areas it is more difficult to make inter-country comparisons of the composition of unemployment as well as to characterise developments over time than in the case of age and gender differences ${ }^{7}$. It is clear, nevertheless, that in most countries unemployment falls especially heavily on persons with a weak educational background (Table 3). It is less clear whether this imbalance is stronger now than in the past: while employment has tended to grow more for persons with better education, the share of better-educated people in the labour force has also increased ${ }^{8}$. For seven countries with comparable time-series data on unemployment by educational attainment, an OECD study found that the increase in unemployment between the early 1970 s and late 1980 s had generally been more pronounced for the least educated workers (OECD, 1989). For some countries, evidence broadly comparable to that contained in Table 3 is available also for 1984. It suggests that changes in overall unempioyment rates, whether positive or negative, have been reflected in larger absolute changes in unemployment rates for groups with weak educational background, and smaller absolute chariges for groups with strong background".

With regard to the regional dimensions of the unemployment problem, available data indicate that absolute differences in regionai unemployment rates have risen in all countries, ieaching very high levels in Canada, Italy and Spain. This can be seen by comparing regions of highest and lowest unemployment rates (Table 4). The standard deviation of unemployment rates across all regiuns has also increased, except in Austria, Norway and Sweden (Table 5, second panel). Nevertheless, measures of the regional dispersion of unemployment, noimalised to take into account the overall unemployment increase, do nct show a clear picture. If the overall increase is large, it swamps the increase in dispersion (Table 5, first panel), so that the normalised dispersion measure declines over time.

In many countries, regicial anemployineiat patterns are highly peristent over tinie, with the United States and, to some extent, Germany, France and Australia as counter-examples, i.e. countries where some change has iaken place (OECD, 1989) ${ }^{10}$. Persistence in the regional concentration of unempioyment occurs rlespite offsetting parterns in participation rates as well as migration flows, reflecting a high degree of persistence in regional eñplo;ment developments as weil ${ }^{14}$. Internal migration flows seem to oe more of a cushioning device in the United States than in Eurcpean countries. This rentects higher mooility in general while it is more difficult to pin down relative sensitivities of the regional wage stricture to regional unemployment aifferences (OECD, 1990; Elarchard and $\mathrm{Katz}, 1992)$.

In the case of Italy, a country of extreme differences in regional unenployment, virtually ail growth in thempioyment over the two latest decades occurred in the South, and the unempicyment rate in the South does not appear to afiect wages in estimated Philiips clirve type wage equations (Bodo and Sestito, 1991). Policies to reduce regional wage differentials, plus transfers and the growth of public employment have sustained ciemand and stifled supply in the South, resuiüng in a permanent southern trade de îcit, high so:thern unemployment (nulling up the national average), rediced migration to the North, and a shift from agriculture to services, with no in:rease in industrial employment in tie South (cf. also OECD, 1990a). For Spain, Bentolila and Dolado (1991) also find declining inter-regional mobility in the context of declining wage differentials and rising overail unemployment and descite increased disyersion of absolute unempioyment rates.

Countries differ strongly in the average duration of unemployment speils. The average unemiloyment rate can be decomposed arithretically into the average duration cf completed unemployment spells and the rate of inflow into unemployment. The difference across countries between these two factors is striking (Table 6). In a number of Europear countries, average durations of unemployment are very high, and unemployment therefore heavily concentrated, implying a high incidence of long-term unemployment. In North America, Japan, Australia, Austria and the Nordic countries, on the other hand, average durations remained comparatively low at the end of the $1980 \mathrm{~s}^{12}$. As regards inflow rates, these are particularly high in North America. The country rankings on these two criteria appear to be relatively stable over time. In most of the countries covered by Table 6 , rising average duration was the dominant explanation, in an accounting sense, for rising unemployment through the 1980 s. 
To streamline the analysis in the following sections, if would be convenient to assemble countries into groups with similar unemployment histories and inaracteristics. This, however, turns out to be relatively difficult, even abstracting from the lack of iniormation for a number of countries. As regards aggregate unempioyment, a few countries with consistently low unemployment such as Japan, Austria, Iceland, Norway, Sweden and Switzerland may be identified, but recent experience makes it difficuit to judge whether they all still belong in that group. In all these countries the available structural indicators, i.e. distribution of unemployment across gender, age and region and the average duration, point to few structural problems. The United States also belongs to the group with few apparent structural imbalances and no major increase in unemployment over time, but the general level of unemployment has tended to be higher. In the remaining countries, aggregate unemployment has risen to a relatively high level since 1970, though by 1992 the level clearly remained below the OECD average in Germany and Portugal. The extent of structural imbalances varies, however, across this large group of countries with, in particular, Italy, Belgium and Spain having serious imbalances in many of the dimensions examined. As is evident from the above, country experience is relatively heterogeneous; where homogeneous groupings of countries can be made, they often differ from groupings based on other relevant features such as institutional set-ups, macro policy regimes, country size etc.

\subsection{The dynamics of unemployment (cycle versus trend)}

Actual unemployment can conceptually be decomposed into a cyclical and a trend component. Against that background, the purpose of this section is threefold:

1. To construct and compare alternative trend measures of unemployment;

2. To relate the cyclical component of unemployment to the cyclical behaviour of output, employment and the labour force, as well as to real wage rigidity;

3. To explore the relation of the cyclical component of unemployment to the trend increase in unemployment.

The insights gained from the analysis are: i) that conceptually very different proxy measures of the unemployment trend lead to very similar results for virtually all countries; and ii) that the countries where unemployment is very cyclical have experienced the largest increase in trend unemployment (with two important exceptions, France and the United States), raising some doubts about the dichotomy between trend and cycle.

Three measures of trend unemployment are considered: the non-accelerating wage rate of unemployment (NAWRU), the unemployment rate associated with a normal vacancy rate (based on the Beverigge curve), and the full-capacity utilisation rate of unemployment (based on the Okun curve). The material is presented for virtually all OECD countries in Figure 3. Based on time-series of observations relating to the three different curves for each country (Figure 3, panels $A$ to $C$ ), corresponding structural unemployment trends can be constructed (Figure 3, panel D) ${ }^{13}$.

If the late 1980s are compared with the 1960s, it seems that currently wages start to accelerate when unemployment falls to a level that is much higher than was previously the case (Figure 3, panel A). The relationship between short-term changes in wage inflation and unemployment may temporarily be influenced by other factors such as changing import price inflation, taxation or domestic profit margins, but these cannot account for the ratcheting upwards of the NAWRU ${ }^{14}$. In some countries, notably the United States, United Kingdom, Belgium, the Netherlands, Portugal and perhaps Canada, there is some evidence that the NAWRU declined through the 1980s.

Vacancy rates and unemployment rates (the U-V or "Beveridge" curve) are compared in panel B of Figure 3. In all countries, with the possible exception of Sweden, the Beveridge curve appears to have shifted out- or upwards. This is suggestive of increased difficulties in matching supply and demand in the 
labour market and, accordingly, of rising trend rather than cyclical unemployment. It should, however, be noted that data on vacancies often are relatively "soft" ${ }^{15}$. In the United States, the United Kingdom, Belgium and Portugal, the previous outward shift of the Beveridge curve seems to have been partly reversed during the 1980s.

Unemployment rates are compared with a measure of capacity utilisation in panel $\mathrm{C}$ of Figure $3^{16}$. It appears that the unemployment rate associated with normal capacity utilisation has ratcheted up in most countries, indicating that the capital stock is no longer geared to employing the full labour force. Again the data suggest there may have been some improvement over the 1980 s in the United States, the United Kingdom, Portugal and perhaps Canada, Belgium and Denmark.

The broad impression from the last panel of Figure 3 is that unemployment rates associated with stable wage inflation, average vacancy rates or normal capacity utilisation have developed quite uniformly in line with the trend of actual unemployment.

Each alternative estimate of the trend unemployment rate gives rise to a cyclical component, defined simply as the difference between the actual and trend unemployment rates. The magnitudes of cyclical variations are quite similar for the different trend measures in different countries, and the crosscountry rankings of these magnitudes coirespond to those for more simple summary measures ${ }^{17}$, like the indicator of variability in the unemployment rate given in the last column of Table 7. This variability is large in North Ametica, United Kingdem, Finland, Ireland and Spain and smail in Japan, France, Austria, Switzeriand and some Nordic countries.

The extent of cyclical fluctuations in the rate of unemployment is the net result of a number of difterent factors opcrating simuitaneously. Some countries, such as Japan, Finiand, Greece, Iceland, New Zealand and Pottugal have had more volatile production than others, such as France, Austria, Eelgium, Norw'ay and Sweden (Table 7, first column). Output fluctuations do not, however, lead to corresponding cyclical fiuctuations in employment in all countries. Employment shows relatively strang cc-variation with o!tput in North Arrerica, Inited Kingdom, Australia, Spain and Sivitzerland while in countries like Japen and taly there is ouly weak pro-syclical movenent in employment (Table 7, second column). Among the factors affecting the employment response to changes in output are the importance of employment protection legisiation, the flexibility of working hours, the extent of firm-specific skills and the modaiities of unemployment benefit systers $s^{1 \dot{3}}$. Based on estimates for, in most cases, either marufacturing or inciustry, it appears that working hours are particularly pro-cyclical in Spain, Belgium, Siveden and Finland (Table 7 , third columen ${ }^{19}$.

To the entent the labour force responds strongly to changes in employment, unemployment will show less cyclical variation. There is evidence that labour forces and employment vary almost in unison in Janan, Austria, Greece, Icsiand, Poriugal and Swiccerland (Table 7, fourth column) ${ }^{20}{ }^{21}$. Responsiveness or the labour force to changing employment may reflect a direct effect related e.g. io workers withdrawing from or joining the labour force, including -- in the case of some countries -migration, but it may also reflect a response to changes in real wages ${ }^{22}$. Indeed, flexible real wages may reduce cyclical fluctuations in unemployment via three channels: output variability is reduced (at least in highly open economies) and both iabour productivity and lanour supply may become more pro-syclical ${ }^{23}$.

The cyclicality of unemployment seems to be systematically related to the unemployment trend: countries with highly cyciical unemployment rates generally have experienced a more pronounced increase in trend unemployment. The figures in Tables 1 and 7 reveal that the five countries with least variability of changes in unemployment were among the six countries with the lowest unemployment rates in the pericd 1985-89, and they were among the six countries with lowest increases in unemployment rates between 1950-64 and 1985-91 (Figure 4). The two countries with the largest fluctuations in the unemployment rate, Spain and Ireland, were also the countries that had both the highest level and biggest trend increase of unemployment. Nevertheless, unemployment is relatively cyclical in United States but 
trend unemployment has hardly risen there, while the opposite is observed in France ${ }^{24},{ }^{25}$. One possible rationalisation of the finding in Figure 4 is that, in countries where unemployment is highly cyclical, a series of negative disturbances could have led to rises in unemployment being superimposed on previous increases, leading to a ratcheting up of the unemployment level.

Univariate time-series analysis of unemployment rates tends to support the notion that unemployment shocks persist, with relatively weak tendencies for unemployment to revert to its starting point. The relatively small number of observations, particularly for the small OECD countries, for which annual data are used, seriously weakens the power of unit-root tests, but even for the countries where trend unemployment has been relatively stable, the standard test, with simple stationarity as the alternative, does not lead to a rejection of the unit-root hypothesis (Table 8). If the alternative includes a drift, a unit root is rejected at the 10 per cent level for the United States and Sweden and at the 5 per cent level for Iceland. Testing against both a drift and a trend, a unit root is rejected at least at the 10 per cent level for the United States, the United Kingdom, Canada, Australia, Finland, Iceland, Spain, Sweden and Switzerland. In the remaining countries, the existence of a unit root cannot be rejected, giving some further backing to the notion that either unemployment does not, or at least does only slowly, return to some equilibrium level, or that equilibrium level has been changing over time (in a way caught neither by the drift nor a time trend). In an attempt to quantify the tendency for unemployment to persist, simple first-order ARMA models have been estimated for unemployment rates in most OECD countries over the period 1969-91 ${ }^{26}$ (Table 8, last two columns). Interpreting the AR(1) coefficient as an indicator of persistence suggests that shocks to unemployment do, indeed, have a persistent effect in many countries; only the United States and Sweden are clear exceptions, with an AR(1) coefficient significantly less than one ${ }^{27}$.

\section{Causes of the trend rise in unemployment}

The preceding sections have demonstrated that trend unemployment has risen in many, primarily European, countries. Little has, however, been said about the character of this rise and the causes behind it. That is the subject of the current section. It first sets out the conceptual framework for the subsequent discussion, then reviews the evidence for interpreting rising trend unemployment as predominantly either an equilibrium phenomenon or a phenomenon of slow adjustment, and subsequently reviews the evidence regarding a number of common explanations for the trend rise in unemployment. In doing so, a distinction will be made between explanations unrelated to structural policy and those that rely on structural policy settings to explain rising trend unemployment.

\subsection{A conceptual framework}

In line with most theoretical and empirical work, this paper accepts the notion that there exists an "equilibrium" rate of unemployment (alternatively labelled the "normal" or "natural" rate), towards which economies gravitate in the absence of shocks, including policy changes ${ }^{28}$. The adjustment towards equilibrium takes time, however, and as discussed further below the adjustment process may be complicated. For that reason, this paper distinguishes between three concepts of unemployment: actual unemployment, which is what is actually observed; trend unemployment, which can be derived as in Section 2.3 and may be influenced by the particularities of the adjustment process; and equilibrium unemployment, defined as above.

Equilibrium unemployment is the difference between normal or equilibrium employment and labour supply ${ }^{29}$. Equilibrium employment and the real wage are determined jointly by the intersection of two schedules. One, the wage-setting schedule, relates real wages positively to employment, reflecting the moderating effect of unemployment on real wages. The other, representing firms' behaviour in respect of 
labour demand and price setting, typically relates the real wage negatively to the level of employment ${ }^{30}$. The latter schedule is likely to shift in response to, inter alia, changes in labour efficiency, the extent of monopoly power, and cost components other than wages. The wage-setting schedule may shift in response to, inter alia, government policies in respect of income support and a change in the level of unemployment that does not represent a "true" imbalance between labour supply and demand, such as frictional unemployment. In addition, all the factors that affect firms' price and labour-demand behaviour are likely to shift the wage-setting schedule, because expected firm behaviour is taken into account in wage bargaining. Sections 3.3 and 3.4 review a number of factors which may shift the two schedules, and labour supply, in order to identify potential causes for an increase in equilibrium unemployment over recent decades.

Unemployment may gravitate only slowly towards equilibrium once a shock has led to a gap between actual and equilibrium unemployment. Section 2.3 presented evidence that unemployment is persistent, and the next section presents some evidence in favour of interpreting this finding as a result of slow adjustment, at least for a number of OECD countries. The reasons for slow adjustment relate to both wage setting and labour demand. In the long run, wage setting is likely to be relatively sensitive to unemployment, but not all of the wage adjustment takes place instantaneously. This implies that a downward shift in labour demand, caused e.g. by a negative disturbance to productivity, initially leads to a larger decrease of employment than will eventually be the case when real wages have fully adjusted. Adjustment is further slowed by labour demand reacting slowly. In the short-run, when the capital stock is given and factor substitutability is low, labour demand is relatively inelastic. Therefore, as the real wage adjusts downwards following a negative disturbance, the immediate effects on labour demand are smaller than the long-run effects. The upshot is that following a negative disturbance to the economy, unemployment could remain above the long-run equilibrium level for quite a while. Moreover, the notion cannot be rejected that if actual unemployment is above equilibrium for a sustained period, this could lead to a rise in equilibrium unemployment. If the economy is hit by a consecutive series of negative disturbances, persistence effects could cumulate. Indeed, OECD economies have been hit by a succession of negative shocks over the two last decades, including higher energy prices, the fall in the growth of total factor productivity and the determined restrictive demand policies pursued in many OECD countries in the wake of the second sharp increase in oil prices in order to bring inflation and budget deficits under control. Sections 3.3 and 3.4 also review the effects of various factors on speeds of adjustment in the labour market.

Looking for explanations of slowly adjusting (or "sticky") unemployment rather than rising equilibrium unemployment puts structural policies and institutions in a new light. While the cause for rising equilibrium unemployment should ultimately be sought in some permanent change of policy or institutions, "stickiness" of unemployment requires no change in policy to generate high unemployment. Some institutions and policy settings may be more conducive than others to ensuring rapid adjustment of real wages and employment in response to outside disturbances even though both sets of institutions and policies may perform perfectly well in their absence.

\subsection{Higher "equilibrium" unemployment or slow labour-market adjustment}

\subsubsection{Wage shares}

Wage shares in the large majority of Member countries have declined steadily over the 1980 s (Figure 5). In a number of European countries (Germany, France, Denmark, Ireland, the Netherlands and Spain), wage shares fluctuated within a relatively narrow range over the 1960 s and 1970 s but since the beginning of the $1980 \mathrm{~s}$, a systematic erosion of the wage share appears to have set $\mathrm{in}^{31}$. By definition, this phenomenon corresponds to average real-wage growth below aggregate labour-productivity growth. This may correspond to an adjustment of real wages, induced by unemployment above its equilibrium level, with the corresponding employment adjustment occurring with a lag. In other countries, though, there is 
high and/or rising trend unemployment, such as, for example, Canada, the United Kingdom, Australia and probably Italy, but no clear signs of a systematic fall in wage shares.

A weakness of the argument based on wage shares is that it is unclear how the functional income distribution should be expected to shift in response to real-wage moderation (though the relative stability through the 1960s and 1970s is suggestive of some self-correcting forces acting on income distribution). With explicit assumptions concerning the underlying aggregate production technology of the economy, more specific predictions may be made. In Figure 6, the marginal product of labour has been plotted for each country under two assumptions concerning the elasticity of substitution between capital and labour in the aggregate production function. The two assumptions have been chosen so that existing estimates of most countries' aggregate technology are contained within the span. The two production functions have been calibrated so that the marginal products of labour on average equalled the real product wage over the period until $1980^{32}$.

The results are suggestive of a negative gap opening up in a number of countries through the 1980 s between real labour costs and the marginal product of labour. Using France as an example, the data presented in Figure 6 suggest close correspondence between labour costs and marginal product of labour in the CES case until around $1980^{33}$. Since then, the marginal product has continued its upward trend, whereas real labour costs began growing at a much lower speed, resulting in a widening (negative) gap between the indices of costs and marginal product of labour. Belgium seems to represent the same situation, whereas for Germany, Australia Denmark, Ireland, the Netherlands and Spain, past real wage developments seem to be more in line with marginal products derived from $\mathrm{CD}$ aggregate technology but, otherwise, the story of a widening gap remains the same $e^{34}$. In contrast, real wages and marginal productivity have apparently not got out of alignment in countries like the United States, the United Kingdom, Austria, Greece, Norway and Sweden.

Evidently, many factors other than real wage developments may affect income distribution and marginal products of labour. The technology of economies may have shifted, firms may invest abroad rather than domestically despite real wage adjustment, higher real interest rates and shorter service lives of capital equipment may have driven up the cost of capital, the degree of monopoly may have changed, etc. The main difficulty with a number of these explanations is, however, that they would be expected to hold in all or most countries, whereas the large shift in income distribution and the gap opening between real wages and (constructed) marginal products of labour are observed only in some.

\subsubsection{Wage formation}

Evidence from very simple empirical wage equations, though subject to the usual caveats concerning this type of analysis, also suggests that actual unemployment may have risen more than its equilibrium level. If the upward trend of the unemployment rate were totally an equilibrium phenomenon, real wages should be responsive only to deviations of unemployment from the trend. Tests of the influence of unemployment on wages are presented in Table 9. Two basic specifications have been estimated: the first is a standard Phillips curve with no priors (such as, for example, homogeneity) imposed (equation 1), while in the second both static (it is specified as a real wage equation) and dynamic homogeneity are imposed (equation 2$)^{35}$. In both equations the level of the unemployment rate, as well as its deviation from trend, enter together as explanatory variables ${ }^{36}$. Alternatively, both equations have been estimated with the unemployment level term in logarithmic form ${ }^{37}$. The estimation results do not support the hypothesis that the trend of unemployment represents equilibrium unemployment. Indeed, the deviation of unemployment from trend is significant with the right sign only for Austria, Denmark and France and, in the latter two cases, the level of the unemployment rate remains correctly signed and significant at the 5 per cent level ${ }^{38}$.

The estimated wage equations also lead to the rejection of the extreme alternative hypothesis, that there are no forces tending to correct unemployment following a shock to the economy. In this case, the 
case of full hysteresis, real wages should respond neither to levels of unemployment, nor to their deviation from trend, but, at most, to changes in unemployment. This has been tested using the same two basic specifications as above, but including the first difference of the unemployment rate instead of its deviation from trend (equations 3 and 4 in Table 9). The estimations indicate that while changes in unemployment have some independent influence on wages, levels of unemployment continue to matter. With the exception of Spain and Sweden, in all cases where the change in the unemployment rate is significant, the level term still has the right sign and in many cases it is significant. The only countries for which the level term remains insignificant, even at the 10 per cent level, across all the various specifications in Table 9 are the United Kingdom, Austria, the Netherlands, New Zealand, Sweden and Turkey ${ }^{39}$.

The simultaneous presence of effects from both levels and changes in unemployment on wages implies a "speed limit" on reductions in unemployment if wage acceleration is to be avoided ${ }^{40}$. If this speed limit is exceeded, it will show up as unemployment being below the short-run NAWRU indicator, presented in Section 2. If speed limits to the reduction of unemployment are relevant, the concept of a NAWRU in level form is insufficient to indicate the degree of inflationary pressures.

Other evidence also supports the notion that unemployment can persist for long periods above its equilibrium level. As discussed above, trend unemployment appears to have risen more in countries where unemployment is highly cyclical. In the absence of stickiness, such a relationship is more difficult to rationalise. While its significance should not be overestimated, the time-series evidence presented in Part 2 also suggests rather weak self-correcting mechanisms, though this could reflect that the specifications of stationarity did not correspond to the actual development of equilibrium unemployment.

\subsection{Possible causes of unemployment outside the area of structural policy}

The current section focuses on factors that are not directly related to labour-market policy. These fall into two main groups: those that are mostly related to the composition of labour supply and demand and comprise demographic changes, frictional unemployment and mobility, mismatch, trade and product competition and relative wage adjustment; and those that are mostly related to aggregate supply of and demand for labour, including aggregate wage adjustment, employment adjustment, technical progress and the influence of budget deficits via high real interest rates.

\subsubsection{Demographic changes}

As discussed above, unemployment rates differ across age and gender sub-groups of the labour force. To the extent such differences reflect inherent characteristics of different demographic groups, such as more frequent job shifts among young workers, changes in the demographic composition of the labour force can affect equilibrium unemployment ${ }^{42}$. The potential impact of such effects is illustrated in Figure 7 by showing how the aggregate unemployment rate would have developed if either a) unemployment rates in individual age and gender groups had remained unchanged at their 1970 levels, but taking into account the changing composition of the labour force, or $b$ ) the composition of the labour force had stayed unchanged since $1970^{42}$, but taking into account actual developments in age and gender specific unemployment rates. The main conclusion emanating from the calculations is that demographic changes, at the given level of aggregation, have mattered very little and, if anything, have tended to slightly reduce unemployment, with groups characterised by relatively high unemployment rates in 1970 having shrunk in relative size since then.

The above calculations treat the influence of demographic change as arising from age-specific features of the labour force. However, different population cohorts may have different characteristics which accompany them through parts or the whole of their labour-market career. Such characteristics may reflect both "exogenous" features, such as level of education and skill, social attitudes, size, etc. but also such things as how successful the first entry to the labour market was. There is evidence based on panel data 
that an unsuccessful entry to the labour market can put persons at a permanent disadvantage in terms of both wage and employment prospects compared with otherwise identical persons who made a successful entry (Bjørn, 1991).

The examples presented in Figure 8 are suggestive of the existence of such cohort effects, with some cohorts seemingly having a consistently better or worse unemployment record relative to the national average than other cohorts. A priori, it is impossible to tell whether these effects relate to so-called "scarring" from a bad start of the labour-market career, or whether it represents an "exogenous" feature of the cohort ${ }^{43}$. Also, in interpreting the evidence presented in Figure 8, it should be noted that these cohort effects are relatively modest and that they do not necessarily result in a similar effect on the aggregate unemployment rate, with other age and gender groups potentially substituting for a cohort with negative attributes.

Apart from the direct effects of demographic change on the equilibrium rate of unemployment, a number of indirect, difficult to quantify, effects may also be at play. For example, rising female participation rates, and the associated increase in the number of two-earner households, together with the rising average age of labour-force participants may reduce both regional and occupational mobility, potentially raising equilibrium unemployment through an increase in labour-market friction and slowing down adjustment to shocks (see below). Predictable demographic change may also lead to anticipatory hiring or labour hoarding by firms, as may have been the case in Japan in recent years. While associated low youth unemployment may reduce scarring effects, the net effect on trend unemployment may not be very significant.

\subsubsection{Frictional unemployment and mobility}

Frictional unemployment is defined as transitional unemployment related to individuals changing jobs, either within or across sectors or regions. The extent of frictional unemployment depends on both the number of job changes and the average duration of intervening periods of unemployment. The latter is affected by a whole range of factors, many of them policy determined, to be discussed below. Here, the focus is first on the frequency of job changes, and subsequently on non-policy determinants of the average duration of transitory unemployment. While there is evidence for only a few countries on developments in the total number of job changes over time, some data on sectoral and regional employment changes exist for a number of countries. Unfortunately, such evidence is highly cyclical, making it difficult to directly infer anything about underlying trends in job shifts and the impact of such trends on frictional unemployment ${ }^{44}$.

Evidence on sectoral and regional shifts in employment is presented in Figure 9, based on data which have been cyclically adjusted and subsequently smoothed ${ }^{45}$. Taking sectoral shifts in Germany as an example, the variation of sectoral employment growth rates (sectoral turbulence) remained relatively constant until the mid-1970s, then declined until the early 1980s and subsequently stayed constant. Employment losses in sectors with declining employment (sectoral shake-out), on the other hand, increased through the 1960s, but started falling already in the early 1970 s and only flattened out in second half of the 1980s. Across countries, the two indicators for sectoral shifts do not always show the same trend but where they do, the indication is that sector shifts have become less important -- the short series for Finland being the main exception ${ }^{46}$. Unlike the sectoral indicators, the regional employment indicators suggest some increase in regional employment shifts since OPECl for a number of countries, including Japan, Italy, Norway and Sweden. In the remaining countries, the indicators do not give a clear message.

The cyclically adjusted indicators, if not smoothed, do seem to have some influence on the development of unemployment (Table 10). Thus, non-cyclical employment losses in the sectoral or regional dimensions seem to be associated with rising unemployment, indicating that the hypothesised effects may be present. But, even if this is the case, the trends presented in Figure 9 suggests that the intensity of 
sectoral and regional unemployment shifts cannot account for a rise in frictional unemployment compared with the $1960 \mathrm{~s}^{47},{ }^{48}$.

To the extent there has been a rise in frictional unemployment, it should consequently be caused not so much by increased frequency of job changes as by increased duration of transitory unemployment spells. Durations will be affected, inter alia, by how "close" to the originating sector or region job openings arise. Here the situation has evidently changed since the 1960 s, when many countries still experienced massive movements from the primary to the secondary sectors of the economy, whereas in the 1980 s, the tertiary sector has been expanding while the secondary sector has contracted $d^{49}$. It is not clear a priori what this implies with respect to transitory unemployment duration ${ }^{50}$.

An important determinant of the degree of frictional unemployment associated with sectoral and regional job changes is the mobility of the workers and/or jobs involved. Lower mobility -- sectoral, occupational and regional -- would raise average duration of unemployment spells associated with normal sectoral and regional job changes and, therefore, increase equilibrium unemployment. Unfortunately, little comparable information exists across OECD countries on levels and developments of sectoral and occupational mobility and their determinants.

Available evidence suggests that geographic mobility within national borders varies significantly across countries, with much higher mobility in the United States, Japan, Norway and Sweden than in continental Europe (OECD, 1990). Regional mobility of workers seems to have declined in the countries with rising unemployment whereas mobility apparently has held up quite well in the United States and Sweden. Causality, however, undoubtedly runs both ways: lower mobility may increase unemployment and, in the reverse direction, as overall unemployment goes up, difficulties in finding jobs increase, reducing migration incentives. Moreover, it is difficult to analyse trends in regional mobility without consistent information on regional wage differentials ${ }^{51}$. Two factors can, however, be pointed to as potentially affecting regional migration. The first is the increased prevalence of two-earner households, possibly having a downward impact on mobility in countries where female participation rates have risen the most. In some countries, such as Sweden, improvements to the public employment services to enhance information flows directed at two-earner households may partly have offset this effect, but also in the United States female labour-force participation has risen rapidly without being associated with a notable fall in migration, casting some doubt on the influence of two-earner households on migration. The second factor is housing policy. Rent restrictions have impeded mobility in a number of countries, but may have become less important over time. The increasing importance of home-ownership as opposed to rented accommodation, which to some extent is the result of tax and regulatory discrimination, may, in conjunction with policy-induced transaction costs, imply increased costs associated with geographical mobility ${ }^{52}$. In addition, movements in relative property prices, and relative rents where they are free to move, across regions usually run counter to the desired migration of workers, regions experiencing a relative decline also experiencing a relative decline in property prices.

Frictional unemployment may be related not only to more permanent reallocation of employment but also to seasonal employment patterns. Sectors with highly seasonal employment patterns will at given times of the year release workers who either have to find jobs elsewhere or remain temporarily unemployed, perhaps returning to the seasonal sector when employment there is rising again. Insofar as a regular seasonal pattern prevails, unemployment related either to seasonal job shifts or having a "waiting" character may not exert much downward pressure on wages, and thereby could raise equilibrium unemployment. For OECD countries for which such data are available, unemployment appears to be particularly seasonal in Germany, Canada, Austria and Denmark (Figure 10). In most countries, the degree of seasonality appears to have either remained relatively constant or has even fallen -- the main exception being Austria. Thus, seasonal fluctuations are unlikely to have contributed to a rise in equilibrium unemployment. 


\subsubsection{Mismatch}

Loosely speaking, mismatch is a persistent imbalance between supply of and demand for labour across skill groups, regions, etc ${ }^{53}$. In contrast to frictional unemployment, it is a long-term phenomenon and reflects differences in the characteristics of the unemployed and jobs offered by employers at going wage rates. Therefore, increased mismatch, if it has taken place, must also reflect a failure of relative wages to adjust and/or inadequate skill acquisition or mobility.

Has mismatch increased and, if so, has it increased more than could be expected on the basis of the general rise in unemployment? As discussed above, Beveridge curves have tended to shift outward in most OECD countries. However, this does not necessarily reflect increased mismatch -- it could also reflect, e.g. increased "choosiness" of employers, reduced search intensity in all individual sub-labour markets or stigmatisation effects of unemployment. Attempts to break down the shift of the Beveridge curve into movements along or shifts in sectoral or regional Beveridge curves have generally not produced evidence that strongly support the notion of an increase in mismatch (Schioppa, 1991a). The weakness of these results should, of course, be seen against the background of poor data quality -- particularly as regards data on vacancies.

Measurements focusing directly on the distribution of unemployment rates across regions, skills, etc., have generally also come up with rather negative findings. A problem often encountered in these studies is the choice of an appropriate indicator of unemployment dispersion. Broadly speaking, two main groups of indicators may be distinguished: those relying on dispersion of absolute unemployment rates and those relying on dispersions of unemployment rates relative to a national average. This distinction is evidently important in countries where the average unemployment rate has been increasing. While the indicators based on absolute unemployment rates are more supportive of increased mismatch, the indicators based on relative unemployment rates generally lead to opposite conclusions. In a review of the merits of the various measures, Abraham (1991) concludes that none is ideal, but that indicators based on relative unemployment rates are probably superior to those based on absolute unemployment rates $^{54}$. A review of a number of studies of regional and skill mismatch suggested that indicators of the latter are generally more flimsy, but that in both cases, the evidence for increased mismatch was limited (Italy presenting, however, a clear case for increased regional mismatch since the 1960s) (Abraham, 1991), a finding which in the case of regional mismatch was supported by Table 5, presented above.

\subsubsection{Trade and product market competition}

Has increased competition from non-OECD countries in world markets resulted in OECD unemployment? It is worth noting that, first, in most OECD countries, the growth of import penetration has slowed since the low-unemployment 1960s; second, countries have experienced no significant downward trends in their net exports, indicating that production for exports has expanded where domestic production has been replaced by imports. At a slightly more detailed level, a mechanical decomposition of employment growth in seven OECD countries is presented in Table 11, based on comparable input-output tables. At the level of the aggregate economy, the following results are obtained: job losses due to increased import penetration were apparently made up for by increased production for export, in all seven countries implying non-negative employment contributions from net exports ${ }^{55}$; job "destruction" through increased import penetration was small compared with the number of jobs which, in an accounting sense, were lost through higher productivity. The two continental European countries contained in the table had lower employment growth than the other countries, arithmetically reflecting relatively slow growth of domestic demand -- not particularly high job losses due to increasing imports.

Small effects at the aggregate level do not, however, preclude that effects associated with structural adjustment may be triggered by simultaneous increase in both imports and exports. Indeed, classical trade theory suggests that trade should lead to such adjustment. This is precisely the mechanism through which the gains from trade are reaped: production shifts to sectors where the economy has an 
international comparative advantage. Increased trade might therefore be expected to be associated with a changing production structure, entailing changes in demand across e.g. skill categories of labour. This is of course especially so if trade expands between countries with very different factor endowments. Special concern has been voiced concerning the impact of imports on manufacturing and in particular traditional manufacturing industries. The data presented in Table 11 confirm that manufacturing employment has developed more negatively than overall employment, but it is also clear from the table that the difference is not primarily related to the contribution coming from trade. The same holds true for "low-technology" manufacturing, which might have been thought particularly exposed to competition from abroad, though there is a slight negative employment contribution from trade for this sector in most countries ${ }^{56}$. In both cases, the dominant contributions to the difference in employment performance compared with the overall economy come from either faster productivity growth or relatively weak domestic demand growth for manufacturing products (though both of these might be indirectly affected by increased trade).

Evidence concerning the impact of trade on skill demands also comes from the recent literature which seeks to explain relative wages across skill categories in the United States. Bound and Johnson (1992) considered the impact from changed trade patterns on the development of relative wages but concluded that it was minor compared with the effect of biases in technical progress across categories of workers. Likewise, Katz and Murphy (1992) concluded that the change in relative demand for various skill categories mainly reflected intra-industry rather than inter-industry changes, even at a detailed level of disaggregation, suggesting that technology factors were more important than trade. A similar conclusion was reached for a number of countries in OECD (1993a). The study by Murphy and Welch (1992) suggests some impact from increased import penetration on increased wage dispersion, but ignores the industrial dimension of wage distribution ${ }^{57}$. Borjas, Freeman and Katz (1991) argue that balanced trade of the sort that predominated in the 1970s and early 1980s had only modest effects on the market for skills, but that the trend increase in the U.S. trade deficit in the mid-1980s led to a marked impact on relative skill demands. In conclusion, the evidence that increased trade in itself has seriously affected the wage distribution is, at best, mixed. This also implies that even if relative wages are inflexible, as appears to be the case in Europe, which has experienced many of the same structural shifts in trade as the United States, trade seems an unlikely prime candidate for explaining increased unemployment.

Competition from imports has, however, also labour-market repercussions that serve to lower both equilibrium unemployment and persistence of unemployment shocks. Increased competition in output markets -- be it of domestic or external origin -- may in itself affect wage bargaining so as to reduce unemployment by weakening the market power of local firms. There is evidence that firms faced with downward-sloping demand curves share monopoly rents with their employees through the wage bargain ${ }^{58}$. As a result, the going wage rate is driven above the level associated with full employment. Moreover, such firms may react less to changes in the external labour market, implying that unemployment shocks and persistence problems could be worsened (Nickell et al., 1992).

Verreydt and Waelbroeck (1982) have provided a case study of the political economy of protection in the EC, singling out the interest groups where lobbying for protection is strongest -- textiles, steel and shipbuilding. They subscribe to the view that changes in employment due to import competition are minor relative to those caused by technical progress, capital accumulation and changes in patterns of demand. More recently, Wood (1991) has re-examined the issue of changes in labour demand in the "North", resulting from increased trade with a "South", which has a comparative advantage in the production of goods that are intensive in low-skilled labour. He comes to the stunning conclusion that the negative impact of trade upon unskilled labour demand in the "North" might be twenty times the conventional estimates, but some of the key assumptions underlying his estimates have been challenged ${ }^{59}$. 


\subsubsection{Relative wage adjustment}

There is a common presumption that at least part of what shows up in Europe as an unemployment problem shows up in the United States as a problem of the "working poor". This difference is taken to reflect the flexibility of relative wages in the United States as opposed to the relatively more rigid, and compressed, wage structures in Europe ${ }^{60}$.

Unfortunately, comparable data on relative wage structures are not readily available to test this hypothesis except as regards the sectoral structure of wages -- which is not necessarily the most relevant dimension of the wage structure in this context. The data presented in Table 12 suggest that in the mid-1980s industrial wage dispersion was particularly pronounced in Japan but also relatively large in North America, United Kingdom, Austria, New Zealand and Switzerland. It was relatively small in most EC countries, particularly in Italy, and in some Nordic countries ${ }^{61}$. The large majority of EC countries had witnessed some compression in the preceding decade, whereas trends outside this area were more uneven, with Japan recording a pronounced increase in dispersion. Correcting aggregate results for changes in the gender pay difference and using fixed employment weights for calculating the dispersion indicator, most countries, with France, Italy, Belgium and Denmark as the exceptions, experienced rising sectoral wage dispersion (Rowthorn, 1992) ${ }^{62}$. The (admittedly rather weak) data in Table 12 also suggest that while wage differentials according to levels of education diminished during the 1970 s, they either stabilised or increased in the $1980 \mathrm{~s}$ in most of the countries covered ${ }^{63}$. These opposing trends of the return to investment in education reflect interactions of supply and demand developments: while the demand for better-educated labour followed an upward trend, relative supply rose more rapidly than demand in the 1970s, but more slowly in the 1980s (Groshen and Drozdowski, 1992; Davis, 1992; Katz and Murphy, 1992; Edin and Holmlund, 1992; Katz et al., 1993). In sum, the review of the limited evidence available suggests that the degree of wage dispersion is very different across countries, but that developments over time in relative wages have been rather parallel across countries, implying a reversal during the $1980 \mathrm{~s}$ of the previous trend towards compression, though probably with most English-speaking countries experiencing a more pronounced widening of wage dispersion than continental European countries. These conclusions broadly conform with the results presented in OECD (1993a).

A number of studies have provided evidence that relative wages affect relative employment prospects. Such effects have often been found to be relatively strong: typically, a certain percentage change in the relative wage is reflected in a larger percentage change in the corresponding employment proportion $^{64}$. The effect on relative and absolute unemployment rates depends not only on employment responses to changing relative wages but also on the impact on participation rates. Estimates of wage elasticities of labour supply vary across different sources but are often found to be positive, though moderate, suggesting that the impact of relative wage changes on group-specific unemployment rates will be stronger than the impact on group-specific employment (Smith, 1991) ${ }^{65}$. However, the availability of jobs is likely to have some independent effect on labour supply, pulling in the opposite direction. In sum, relative wage changes are likely to have sizeable impacts on the distribution of unemployment.

The distribution of unemployment is likely to influence overall wage levels and therefore overall equilibrium unemployment, as discussed in the context of demographic change ${ }^{66}$. Italy is a clear example of unemployment rates being very unbalanced in both the age, gender and regional, though not educational, dimension, and a very compressed wage distribution. Wage convergence between eastern and western Germany is also leading to higher unemployment in the former. It is also noticeable that some of the highunemployment European countries have particularly high relative female unemployment rates. Nevertheless, the evidence presented in Section 2.1 does not show a general tendency for countries with high unemployment to have unemployment imbalances that are worse than could be expected given aggregate unemployment ${ }^{67}$. As regards changes over time, few countries can be identified where the degree of regional and age-specific mismatch has unquestionably increased. Again, Italy is the main exception ${ }^{68}$. A relative rise in female unemployment is clearly discernible in high-unemployment countries like Italy and Spain, where, as elsewhere, some narrowing of the gap between male and female wages has taken place. 
Among the potential causes for inadequate adjustment of relative wages, the most obvious candidate is perhaps statutory minimum wages, which are discussed further below ${ }^{69}$. Another policy-induced disturbance is the impact of the structure of unemployment-benefits replacement rates, where in some countries low statutory maximum benefits interact with high statutory replacement rates to create a highly skewed distribution of effective replacement rates, leading to a more compressed wage structure ${ }^{70}$. Conceivably, public-sector wages and wage relativities may also affect conditions in the private sector (see Section 3.3.6.1). The institutions of wage bargaining may also be more or less conducive to flexible relative wages or compression of the wage structure. Rowthorn (1992) finds evidence that a higher degree of centralisation of wage bargaining implies a tendency towards a more compressed wage structure.

\subsubsection{Aggregate wage adjustment}

\subsubsection{Social attitudes, union militancy and public-sector wage setting}

In countries where unemployment has been high for a long time, a shift in social attitudes may have taken place, no longer implying any social stigmatisation of persons experiencing long periods of unemployment as a result of very slow adjustment of their reservation wage. Differences across countries and over time in such general attitudes can, in principle, significantly affect both equilibrium unemployment and the speed of adjustment following a shock, but given their nature it is very difficult to measure them.

One factor more readily observable and measurable is the militancy of unions and the resistance of employers to grant wage increases. Indicators of union militancy, such as the frequency of strikes, suggest that in many countries strike activity rose in the 1970 s compared with previous decades. In the 1980s, strike activity has receded but whether this reflects a fall in underlying militancy or just reflects a "cyclical" effect due to high unemployment is difficult to say. Due to limited data comparability, cross-country differences in strike activity should be considered only a weak and indirect indicator of the climate on countries' labour markets. Nevertheless, the size of observed differences is striking, with roughly ten times as large a proportion of Italian workers engaged in strikes during a year than in the United Kingdom, Denmark and Ireland where again ten times more workers were involved in strikes during the 1980s than in the United States, Japan, Austria and the Netherlands - - with a further factor of ten down to the Swiss level. While this pattern may seem suggestive in the light of the cross-country pattern of unemployment rates, it should be noted that the pattern of strike activity across countries showed very large differences also in the full-employment $1960 \mathrm{~s}^{71}$.

A third factor which may affect attitudes on the private labour market is the available alternatives open to wage eamers in the form of public-sector wages. Thus, to the extent public-sector wages rise faster than private sector wages, this may increase wage pressures also in the private sector, entailing a rise in the unemployment rate associated with stable inflation. Conversely, public-sector wage restraint may be seen both directly as reducing the attractiveness of the alternative to private-sector employment and, in a wider framework, as a sign of the determination of the authorities not to accommodate high wage increases, which should also damp wage pressures. Empirical evidence based on average wages in the private and public sectors over the last two or three decades suggest that in virtually all countries, private-sector wages have given the lead and public-sector wages have tended to follow (see Technical Annex) ${ }^{72}$.

\subsubsection{Slow real-wage adjustment}

In many OECD countries subjected to higher prices of energy imports in the wake of the two rounds of oil-price increases, wage earners responded by trying to seek compensation for the terms-of-trade loss in higher wages, in some countries helped by automatic wage-indexation mechanisms. This led to dismissal of labour and reductions in output. Increased unemployment subsequently put downward pressure on real wages. Unemployment rose most, and remained high for longer, in countries where the resistance by labour to accept the terms-of-trade loss was the strongest and where wages responded little and slowly to higher unemployment. This is illustrated in Figure 11, which plots a measure of short-run real-wage 
rigidity against the rise in unemployment since $1973^{73}$. In the case of the OECD-wide slowdown in productivity growth, similar mechanisms were at play, though the process was more gradual and the timing is somewhat uncertain given the difficulties of measuring trend total factor productivity. Against this background, it is of interest to ask what institutional and policy frameworks a) directly lead to the absorption of negative terms-of-trade and productivity disturbances in real consumption wages, so as to reduce the initial effect on employment and b) imply a quick and large effect from rising unemployment on real wages, so as to return real wages quickly to a level consistent with full employment, a precondition for avoiding stickiness of unemployment above its equilibrium level.

The institutional set-up of wage bargaining will affect both of the above mechanisms. At one extreme, in perfect competition agents will adjust real wages so as to ensure continuous full employment. At another extreme, a monopoly union concerned with employment rather than real-wage levels might adjust the level of real wages in line with the outcome of perfect competition. While the role of the institutional arrangements in the wage bargaining process has been noted for some time, the emphasis of analysis $^{74}$ and the interpretation of results has shifted considerably over time ${ }^{75}$. Most of the empirical evidence has focused on the persistence of unemployment which, as mentioned above, may not just reflect slow real wage adjustment but also slow employment adjustment and in practice is difficult to distinguish from rises in equilibrium unemployment. Here it may suffice to say that a number of authors have tended to find some evidence of a hump-shaped relationship between indicators of the "market power" of institutions and the flexibility of real wages, as indicated in Figure 12 (an overview is presented in Calmfors, 1993).

As unemployment rises in response to a shock, there is initially some response of wages as persons get laid off, but when unemployment stabilises, those remaining employed (the insiders) may seek to obtain a level of real wages consistent with maintaining employment rather than let the real wage adjust to re-absorb the unemployed. For this to occur, the unemployed outsiders must either have insufficient incentives for, or be otherwise prevented from, pricing themselves back into jobs. Among the mechanisms which could cause such a situation is the use by employers of unemployment, or long-term unemployment, as a screening device when hiring new employees. Insider mechanisms could be particularly strong where there is a strong statutory seniority system, implying that a large part of the work force is virtually not subject to any risk of job loss. Job security legislation, which is discussed further below, may be seen as establishing a statutory seniority system, thereby preventing outsiders from providing efficient competition for jobs. While, in principle, the outsiders could make up for such factors by accepting a (at least initially) lower wage, such an adjustment may be ruled out due to the existence of minimum wages, strict pay scales or harassment by work colleagues (established insiders).

As regards empirical evidence, the estimates of wage equations reported in Table 9 could, for a number of countries, be interpreted as supporting the conjecture that the speed of real-wage adjustment falls after an initial disturbance to unemployment. The equations suggest that if unemployment shifts to a higher level, wages will initially respond to both the change in unemployment and its higher level but subsequently only the effect from the higher level will subsist. If the incidence of long-term unemployment is taken as an indication of the dis-enfranchisement of outsiders, results reported in Heylen (1991) suggest that employment protection legislation may have the discussed effects. Both Holmlund and Zetterberg (1991) and Nickell et al. (1991), on the other hand, find little evidence of insider effects when studying, respectively intra-sectoral and intra-firm wage developments ${ }^{76}$. Flanagan (1988) comes to similar conclusions by examining the influence of firm-specific labour utilisation as compared to unemployment in explaining wage developments. These results seem to be quite symptomatic and have led some to conclude that wages depend much more on developments in the outside labour market than on firm-specific or industry-specific factors related to insider power (Layard et al., 1991).

Other factors also affect the speed of real-wage adjustment. Long duration and generous levels of unemployment benefits are likely to entail slow adjustment of reservation wages. Indexation schemes also applicable to price disturbances which make the whole economy poorer, such as adverse terms-of-trade 
shocks, played a role in the slow adjustment of real wages in some countries following the first round of oil price increases. Such schemes have, however, generally been abolished. Finally, it may be worth noting that while experiences with more permanent incomes policies have been, at best, mixed, attempts to speed up wage adjustment in the face of disturbances through nation-wide, co-ordinated agreements appear in some cases to have been successful in shortening the adjustment period (thus reducing adjustment costs), as may have been the case in a number of Nordic countries in recent years.

\subsubsection{Slow employment adjustment}

The discussion in Section 3.2 suggests, that in many European countries where unemployment levels have been high since the late 1970s, there has been an adjustment of real product wages (relative to labour productivity) in the 1980s. The decline in the labour share indicates that either employment has not yet fully responded to this adjustment or there has been a shift in the full-employment relationship between real wages and productivity. While the latter cannot, a priori, be excluded it should be noted that such change does not appear to be visible in other OECD countries, such as United States, Japan, Austria, Finland and Switzerland, that at least until recently have maintained relatively stable unemployment.

Empirical evidence suggests that speeds of employment adjustment differ considerably across countries. Mostly, such evidence has concerned the response of employment to variations in output, where the indication is that employment responds relatively rapidly in North America and Denmark, while the response is relatively slow in Japan, Italy and Sweden ${ }^{77}$. The evidence concerning adjustment speeds to changes in real wages is generally less robust. Alogoskoufis and Manning (1988) present evidence to suggest that short-term responses to changing real wages are particularly strong in the United States and Switzerland and particularly weak in France, Italy, Belgium, the Netherlands and Norway.

The causes for differing speeds of adjustment across countries are numerous and include inherent features of the economies such as the structure of production across sectors. Structural policy also matters with employment protection legislation reducing speeds of adjustment in both upward and downward direction (see below). Speeds of adjustment may also vary over time, dependent on the degree of uncertainty with regard to the future facing firms. Flanagan (1988) presents evidence suggesting that uncertainty with respect to output increased in some countries in the 1980 s.

The possibility of asymmetric adjustment speeds cannot be excluded. It is noticeable, that neither the rise in the share of labour nor the gaps between real wages and marginal products appear as large during the 1970s as they do (in the opposite direction) during the 1980s in some European countries. Thus, adjusting productivity upwards to an elevated level of real wages by closing low-efficiency capacity and firing low-productivity workers may be a process that is more readily implemented than expanding capacity and hiring new workers. Based on disequilibrium models for a number of European countries, Drèze and Bean (1990) present indicators of the importance of capacity constraints on output growth until 1986. For most countries, output was predominantly constrained by aggregate demand rather than capacity or available labour supply. There was some indication, though, that capacity constraints became more important in the mid-1980s in Germany, Denmark and the Netherlands. This undoubtedly was the case also in other countries during the second half of the decade as indicated by rising business investment. High real interest rates, caused inter alia by rising public-sector indebtedness, may however have held back expansion of capacity.

\subsubsection{Technical progress}

Technical progress biased towards labour saving has sometimes been invoked as a cause of rising trend unemployment. At a first glance this may seem surprising, since technical progress, as proxied by the Solow residual ${ }^{78}$ has slowed in most countries either just prior to or simultaneously with the trend increase in unemployment. Indeed, at the aggregate level most arguments would seem to run in the opposite direction: a slowdown in technical progress may be a cause of higher unemployment. A 
slowdown in technical progress requires slower real wage growth to maintain full employment. However, real wage aspirations may only adjust slowly to an (unexpected) reduction in the speed of technical progress, leading to temporarily higher unemployment to offset inflation pressure resulting from excessive (relative to actual productivity advances) real wage aspirations. While this is clearly a temporary effect, equilibrium unemployment may also be raised as a result of slower technical progress as wage restraint is reduced $^{79}$.

At the aggregate level, the main opposite argument, i.e. for a slowdown in technical progress leading to less unemployment, is related to the impact of the speed of growth on frictional unemployment. As mentioned above, there are some indications that unemployment may increase in conditions of rapid sectoral change, the intensity of which normally varies with the growth rate ${ }^{80}$.

Evidence based on experience from the United States indicates that technical progress has had an important influence on relative wages over recent decades. Indeed, several authors have identified a shift in labour demand towards better educated workers, though there is some disagreement as to whether this is a more permanent trend or mainly a feature of the 1980s (Groshen and Drozdowski, 1992; Juhn et al., 1991; Katz and Murphy, 1992; Murphy and Welch, 1992; Katz et al., 1993). As noted above, Bound and Johnson (1992) and Katz and Murphy (1992) conclude that technical progress biased for and against different categories of labour is the most important reason for increased wage dispersion across skill/education categories. If the same developments occur elsewhere, but with inflexible relative wages, this could have amplified the bias of unemployment towards the less skilled, possibly leading to higher overall unemployment. However, given the general slowdown in technical progress, this could explain higher unemployment only if the extent of bias in technical progress has risen, relative wage rigidities have increased, or the speed of reduction in the proportion of less-skilled workers has fallen.

\subsubsection{Budget deficits and high real interest rates}

Across OECD countries, real interest rates have been higher in the 1980s than in previous decades driven, inter alia, by government budget deficits (Tease et al., 1991). Higher interest rates increase firms' cost of capital. To the extent this is not fully recognised in wage bargaining, unemployment will have to be higher to equilibrate firms' and employees' real-wage and mark-up demands ${ }^{81}$. This effect may, however, be only temporary to the extent wage earners' real-wage aspirations just need time to adjust to higher real interest rates ${ }^{82}$.

It has been argued that the high cross-country correlation of unemployment trends suggest that developments of an international character, such as the rise in real oil prices and real interest rates, have played an important role (Phelps, 1992). However, as discussed above, country experiences with respect to unemployment do show important differences. Perhaps reflecting this, empirical work on the impact of real interest rates on unemployment is relatively scarce. Manning (1992) estimates real-wage Phillips-curves derived from a wage-bargaining model for 19 OECD countries including real interest rates as a proxy for discount rates. Generally, real interest rates do not have a significant effect on real wage growth, with the United States, Japan, Australia, Denmark and Netherlands as the only countries with a significant and correctly signed effect. The size of the effect varies, with a 1 percentage point increase in the real interest rate raising the unemployment rate by 0.05 percentage points in Japan, 0.3 in Australia, 0.4 in Denmark, 0.7 in the United States and 1.2 in the Netherlands. Darby et al. (1992) estimate a vintage production function for the United Kingdom and embed it in a wage bargaining framework. They obtain the result that the rise in real interest rates between the 1970s and 1980s could have doubled the NAIRU. Finally, Phelps (1992) in a pooled cross-section time-series regression including 17 OECD countries finds that an increase of 1 percentage point in the real interest rate has a steady-state impact on the unemployment rate of $0.1-0.4$ percentage points depending on the country. Taking into account the role of public-sector debt in the determination of real interest rates in his model, the author finds that most of the increase in OECD unemployment between OPEC 1 and the end of the 1980s can be accounted for by rising public-sector debt. 


\subsection{Structural policy and unemployment}

Government policies vis-à-vis the labour market may aiso be responsibie for rising unemployment. Laws and regulations guide behaviour on the labour market and private agents' incentives are affected by the spending and financing patterns of the public sector. In principle, all structural policies are likely to affect behaviour on the labour market. However, this paper focuses on some relatively well-identified areas of structural policy that have a direct bearing on labour-market outcomes and the extent to which such structural policies have contributed to rising unemployment during the period under consideration.

Two problems are common to the identification of the effects on unemployment stemming from structural policy. First, government intervention contains a large number of detailed rules and regulations that differ across countries and cannot be treated in a summary way. The fact that such details cannot be dealt with comprehensively here does not indicate that they are not considered important. Second, structural policies may give rise to different behaviour at different times and in different countries. In particular, where policy gives rise to problems of moral hazard, such as is obviously the case, for example, in connection with unemployment benefits, unintended use or direct misuse of programmes may occur only gradually over time, partly because learning about the programmes is slow and partly because customs may change slowly in response to altered incentives or more general developments.

\subsubsection{Unemployment benefit systems and other social transfers}

Income support during periods of unemployment would, like any other non-work related income or transfer, be expected to weaken the effort to search for work and the willingness to accept job offers. This effect should unambiguously tend to raise equilibrium unemployment. In addition, the knowledge of having a generous benefit system to fall back on may strengthen the resolve and bargaining power of wage earners when negotiating over wages. Offsetting the resulting wage pressure may require a higher rate of unemployment. Moreover, the financing of benefits may affect the sectoral composition of employment, the extent of temporary lay-off and seasonal unemployment, and potentially overall unemployment. In the absence of experience rating, firms that have very volatile employment and frequent lay-offs are implicitly receiving a subsidy from other firms with more stable employment since without unemployment benefits they would have to pay higher wages to attract workers ${ }^{83}$. Other effects are more ambiguous or may even work to reduce the impact of the above effects on the equilibrium unemployment rate. Thus, unemployment benefits may be seen as a subsidy to job search which may lead to better job matches, reducing the number of repeat spells of unemployment and increasing future productivity ${ }^{84}$. Also, benefits, where financed fully or in part via the government budget, may be seen as a subsidy to labour-force participation, increasing the mean and reducing the variance of expected income, and thus raising participation rates.

Different- elements of benefit systems -- income support level, duration of income support, tightness of administration etc. -- are likely to have different impacts on the various incentives mentioned above. It is no simple task to summarise what policy changes have taken place and to quantify how they have affected unemployment developments. A general impression is that, in many dimensions, the generosity of unemployment-benefits systems increased during the 1960s and early 1970s, when improvements came cheap because unemployment was low, which made it easy to check misuse. Later, political pressures led to some further increases in generosity in response to rising unemployment, e.g. extending maximum duration of benefits when this limit began to "bite". During the decade of the 1980s, some governments have tried to move in the opposite direction; paring back costly benefit schemes thought to give the wrong incentives. These trends are recognisable in some, but far from all, countries in Figure 13. Partly this may be because the generosity ratios reported in the Figure are poor indicators of system generosity, e.g. because in some countries administrative costs of the system enter into the expenditure figure, or because of compositional effects within the group of unemployed, with benefit levels differing between different categories of unemployed ${ }^{85}$. Based on a snapshot across countries for 1988 , 
an OECD study looking in much greater detail at the various components of benefit systems found evidence that in countries where replacement ratios decline little over long spells of unemployment, the incidence of long-term unemployment appears to be relatively high (OECD, 1991).

In principle, impacts of unemployment insurance and related social transfers on individual behaviour can best be studied using panel data sets. Available studies, which are predominantly North American, have generally confirmed most of the mechanisms discussed above, but have yielded mixed results concerning the magnitude of the effects that various aspects of benefit systems have on the propensity of individuals to become employed or unemployed, or to leave the labour force ${ }^{86}$. Estimations based on panel data from continental European countries have generally had difficulties in finding significant effects ${ }^{87}$. For overviews of such results, see Atkinson and Micklewright (1991); Björklund and Holmlund (1986); and Pedersen and Westergård-Nielsen (1993).

Empirical evidence using aggregate cross-country data has generally come up with much larger effects $^{88}$. To some extent, this may reflect co-variation between income-support systems and a host of other country-specific factors, with income-support variables picking up also the impact of such other unmeasured factors ${ }^{89}$, as well as the above-mentioned reverse causation of unemployment leading to pressure for increased generosity of benefit systems. Partly, however, the difference between the panel data and aggregate cross-country results is likely to be real and to be related, inter alia, to the impact of unemployment benefits on wage bargaining. The strengthening of wage earners' bargaining position as a result of generous unemployment benefits is likely to be captured in the cross-country analysis, but this effect cannot be easily isolated with panel data ${ }^{90}$. Moreover, as noted above, unemployment benefits may slow down adjustment of reservation wages and thereby act to promote the stickiness of unemployment above equilibrium levels in the wake of a negative disturbance. Such influences are also more likely to be captured in cross-country estimations based on aggregate data. For some of the countries where the generosity of the unemployment compensation system has changed, there is evidence that this has affected wage formation, though the evidence is not specifically based on tests of speeds of adjustment as opposed to effects on the equilibrium level of wages. All in all, therefore, increased generosity of unemployment benefit systems as well as their effects on slowing down speeds of adjustment may, at least in some countries, have given a non-negligible contribution to higher unemployment.

Social transfers other than unemployment benefits also have important labour-market repercussions. This holds in particular for schemes directed at older age groups, but in some countries invalidity schemes also seriously affect labour markets. In virtually all countries, withdrawal from the labour force has tended to occur at lower ages than it previously did". To a large extent this reflects an important number of policy initiatives aimed at reducing labour-force participation among older persons (Table 13). In many cases, such policy initiatives were explicitly aimed at reducing unemployment. Whether they had this effect over anything but the very short run is dubious. It would seem that equilibrium unemployment has been reduced only to the extent that workers retiring earlier had less weight in wage bargaining than other workers, implying that the main effect may have been to reduce employment. While little information exists on the effects of these policies, they seem unlikely to have mattered much for unemployment.

\subsubsection{Employment protection legislation (EPL) and working time}

Many, predominantly European, countries impose restrictions on firms' freedom to hire and fire workers. While there is virtual theoretical unanimity that these restrictions importantly affect the dynamic hehaviour of firms' employment decisions, an agreement that is borne out also by empirical evidence ${ }^{92}$, there is much less agreement on the impact they have on equilibrium unemployment ${ }^{93}$. While employment protection legislation (EPL) -- if it is binding -- may .represent an increase in labour costs, this could in principle be neutralised if wage earners were willing to accept, and minimum wages did not prevent, a corresponding wage cut $^{94}$. The main impact of EPL may be indirect. Thus, EPL is likely to stifle labourmarket turnover, implying that unemployment is generally of relatively long duration, and the unemployed 
therefore relatively less effective in putting downward pressure on wages, which may lead to an increase in their number. EPL is also likely to increase the concentration of unemployment among workers with low (firm-specific) skills, since it is the costs of these workers that is likely to be increased most by EPL, while in the case of more specialised labour firms may anyway be very reluctant to fire. The existence of EPL may also exacerbate the effect of other changes on equilibrium unemployment. Thus, it seems likely that if the general sense of risk, e.g. related to output, among firms increases, they may respond by reducing employment for any given real wage. Conversely, implicit contracts between firms and employees to make use of the unemployment benefit system during periods of slack demand may be discouraged by EPL and the increase in transaction costs it generates.

The stringency of EPL varies considerably across countries, with countries such as Italy, Belgium and France generally considered as having some of the tightest regimes and United Kingdom and Denmark having the most liberal EPL regimes in Europe, while there is essentially no general EPL at all in the United States ${ }^{95}$. Over time, many countries tightened EPL through the 1960s, often with the consent of the social partners who in conditions of full employment saw little harm in this (Figure 14). Some countries (e.g. France) even responded to rising unemployment after OPEC1 by further tightening of EPL. Through the 1980s, reforms have been undertaken in a number of countries, but it seems fair to say that these have not really reformed EPL as such, but rather made it easier to circumvent existing regulation by allowing short-term contracts etc. which are not covered by EPL ${ }^{96}$. In countries such as France and Spain, a major part of employment growth in the late 1980s took the form of temporary contracts.

There is almost no empirical evidence on the impact of EPL on equilibrium unemployment. Most of the empirical evidence has been concerned with its impact on the adjustment of unemployment following a disturbance, and has tended to confirm that it slows down adjustment speeds by directly affecting employment decisions and, potentially, also by retarding real wage adjustment due to increased influence of insiders. The effects of EPL on raising the incidence of long-term unemployment has received some support in cross-country analysis, suggesting also a likely influence on equilibrium unemployment ${ }^{97}$.

Another direct government regulation of labour markets is the statutory ceilings imposed on working time. Reductions of working hours have been legislated, ostensibly with the aim of sharing "the available amount of work" more broadly and thereby reduce unemployment. Such attempts are not likely to have had any success. To the extent they have been effective, i.e. that employed persons have reduced their working time and unemployed persons have been employed, wage pressures are likely to have risen, forcing unemployment back up. Looking at actual annual working hours, Figure 15 suggests that rises in unemployment and cuts in working time are positively correlated across countries. This is indicative of some influence from unemployment on attempts to reduce working time but does not confirm any effect in the other direction.

\subsubsection{Minimum-wage legislation}

Both the actual and desired effect of imposing a minimum wage is to truncate the distribution of wages at some level. As a result, it is no longer profitable for firms to employ workers with a productivity level (perceived to be) lower than that corresponding to the minimum wage, and these workers will consequently be unemployed. In addition, the imposition or increase of a minimum wage may pose the risk of "knock on" effects above it, leading to some upward drift in the general wage level, tending to raise unemployment further. Partly mitigating these effects, minimum wages may reduce or even eliminate the detrimental employment effects resulting from monopsonistic behaviour of employers. In principle, this could bring about an increase in both wages and employment, though such an outcome seems unlikely. Nevertheless, effects of this character may partly explain why the imposition or increase of a minimum wage typically leads both to a reduction in employment among the lowest skilled, but also an increase in wage rates combined with continued employment for some persons. Minimum wages may also interact with other structural policies. For instance, to the extent that enhanced EPL raises the costs of employing low-skilled labour, minimum wages may prevent an offsetting adjustment of their relative wage ${ }^{98}$. 
Similarly, increased trade with countries endowed with abundant low-skilled labour may lower the wage for such labour. However, to the extent there is downward pressure on wages of low-skilled, and no skill acquisition, minimum wages will result in unemployment. Minimum wages are also likely to slow down adjustment of real wages following a disturbance, because they prevent unemployed workers without firmspecific human capital from providing effective competition for jobs.

Many OECD countries have minimum wages. However, they exist in different forms: either legally-imposed uniform wage rates, or bargained rates, or some form in between. Across countries, Netherlands and Denmark have minimum wages that are relatively high in comparison with average wages, whereas levels in e.g. Spain and the United States are much lower. Over time, minimum wages have tended to decline relative to average wages during the 1980s, with France as the major exception, while previous trends differed across countries (Figure 16). The coverage of minimum wages has broadly mirrored their relative level, with France being the only country where a larger part of the employed were covered by the minimum wage in 1990 than in 1980.

Much of the empirical evidence concerning the impact of minimum wages has been related to its impact on youth employment rather than its impact on aggregate unemployment. Without being hard evidence, the data in Figure 16 are suggestive of a link with youth unemployment, with young workers likely to be particularly affected by minimum wages 99 . More elaborate studies have, however, generally come out with rather modest minimum-wage effects on youth employment. The existence of a relationship between relative minimum wages and aggregate wages has received some support in the case of France and Netherlands (van den Heuvel, 1992). The shake-out effects of a large increase in the minimum wage have been documented for Denmark (Albæk and Madsen, 1989). So far, however, most empirical evidence points to rather modest effects on total equilibrium unemployment

\subsubsection{Taxation}

Rising taxation on labour use has sometimes been süggested as a cause for rising unemployment. Over the short run, it seems indeed obvious that a rise in tax rates may raise labour costs, diminish employment and raise unemployment. However, the long-run effects of a tax increase are more doubtful. Within a bargaining model of labour markets, long-run effects on unemployment may be expected to be small, provided the tax hike preserves the relation between the real consumption wage and real after-tax unemployment benefits, because workers' gain by being employed remains unchanged in this case. A further argument for assuming real consumption wages to take a large part of the long-run adjustment to a tax increase is that workers may regard higher taxes as the financing side of the provision of government services to which they attach some value or, as in the case of some social security contributions, taxes may even have the character of (forced) saving. Labour supply, and consequently employment, may however be negatively affected by higher taxes to the extent that substitution effects dominate income effects in the decision to supply labour. Different frameworks, nevertheless, give different predictions, implying that the long-run effects of taxation on unemployment is an essentially empirical question. This question is made more complicated by the existence of different tax instruments, not necessarily having the same impact ${ }^{100}$.

Tax pressures have been rising significantly in all countries over the past $21 / 2$ decades -- also in countries that did not witness any marked increase in unemployment rates (Table 14). Most of the rise in tax pressure, however, occurred before 1979. The rise was concentrated on personal income taxes and employers' payroll taxes, while indirect taxes remained relatively stable ${ }^{101}$.

The more or less constantly rising tax pressure would imply that unemployment could have been higher during the whole of the last three decades just because of the short-run effects of increased taxation on unemployment -- even if there were no long-run effects on unemployment. This would, however, hardly explain rising unemployment since the mid-1970s, in particular as the rate of increase of tax pressure has tended to fall over time. On the basis of empirical evidence, it also seems difficult to explain rising unemployment by short-run effects of a changed composition of the tax revenue -- thus, taxes on employers 
which may have the most severe short-term inpacts did not rise very much on average during the 1980 s. Across economies it seems to be the case that long-run effects of higher tax rates on unemployment have been more pronounced in big and relative closed economies bit such effects have tended to dwindle over time, a process potentially related to increased openness and globalisation (Kostoris, 1991). On the basis of the available evidence, it thus seems unlikely that changing tax rates can account for much of the ise in equilibrium unemployment ${ }^{102}$. This does not preclude, however, that high marginal tax rates in conjunction with income-dependent social transfers and public services may act to slow down the speed of adjustment of reservation wages following a negative disturbance to the economy.

\subsubsection{Manpower policies}

So-called active labour-market policies comprise a host of individual policies related to training, counselling, employment services and job offers. Some of these are probably more relevant in determining how unemployment responds when an economy is hit by a negative disturbance rather than in determining equilibrium unemployment. These two aspects cannot, however, be seen in complete isolation: If unemployment is allowed to persist for long following a negative disturbance, some of the unemployed may drift into long-term unemployment, lose contact with the labour market and exert no disciplining effect on wage bargaining. To the extent this occurs, it would boost equilibrium unemployment. In terms of direct effects on equilibrium unemployment, the quality of counselling, information dissemination etc. may affect frictional unemployment. Moreover, the extent of supervision of the unemployed may have an impact on the seriousness of moral hazard in connection with unemployment benefits ${ }^{103}$.

Governments' efforts in the field of active labour-market policies have generally not matched their stated intentions. For the OECD as a whole, budgetary outlays on active labour-market policies remained unchanged as a share of GDP between 1985 and 1991, the short period covered by data, at a level slightly below $1 / 2$ per cent (Table 15 ). Not having risen by much is, however, far from having fallen which would have been the development needed to give a contribution to higher equilibrium unemployment. Nevertheless, the intensity of active labour-market policies may have fallen over recent decades: per unemployed person the resources involved in active labour-market policies are likely to have fallen, given the increase in unemployment. Different stances with respect to active labour-market policies may have contributed to different unemployment developments across countries. However, evidence from crosscountry analysis, which seems to confirm such a potential role, appears to be in conflict both with evidence based on micro-observations, which has had difficulties in documenting such effects at the individual level ${ }^{104}$, and with evidence suggesting that active labour-market policies could add to wage pressures ${ }^{105}$.

\section{Summary}

Although reducing unemployment on a sustainable basis is a key objective of economic and social policy, the definition of unemployment is ambiguous and its empirical measurement far from precise: pro-cyclical variations in the labour force, the extent of which is influenced by country-specific institutional arrangements (including prevailing labour-market legislation), reduce the reliability of the measured unemployment rate as an indicator of intensity of labour utilisation over the business cycle. Apart from cyclical variations, there is evidence that persistently high unemployment depresses participation rates, which implies that observed inter-country differences in unemployment rates tend to understate the differences in "true" labour-market slack.

Concerning the structure of unemployment, its concentration among young people is a notable feature in many countries. Another significant feature is that unemployment falls disproportionately on persons with little training and skills. Together, these characteristics (partly) reflect the failure of the educational system to manage a proper transition from school to working life, which will affect a person's 
(un)employment record through the rest of his/her professional career. Finally, in the countries where unemployment has increased most, the share of long-term unemployment (more than six consecutive months) now exceeds half the total, in some instances substantially so.

A noteworthy finding of the paper is that in virtually all member countries various alternative measures of trend unemployment, associated with the notion of non-accelerating wage-inflation, normal utilisation of physical capacity, and normal vacancy rates respectively, give very similar results. While these alternative trend measures of unemployment follow the moving average of actual unemployment in each country fairly closely, trend unemployment differs considerably between member countries. The trend increase in the unemployment rate in many OECD countries under way since 1973 poses a major challenge to economic policy makers in these countries. To respond appropriately to this problem, it is necessary to first identify the causes for the observed increase.

In the large majority of Member countries, substantial rises in unemployment occurred in the wake of the sharp oil-price increases of 1973/74 and 1979/80, which were superimposed on a significant slowdown in the growth of total factor productivity, starting around 1970. There were, however, important differences across countries in the size of these bursts of unemployment: countries with highly cyclical unemployment rates have typically experienced the largest increases in trend unemployment. Among the factors curtailing the cyclical variation of unemployment is the willingness and ability to respond quickly to adverse terms of trade and productivity disturbances by reduced real income claims, which in turn is importantly influenced by the interaction of social partners in the labour market and by labour-market policies.

Among the countries where unemployment at first did increase strongly, it declined in some during subsequent cyclical recoveries, while it remained stubbornly high in others. Two factors may account for the persistence of high unemployment in some countries: the first is slow labour-market adjustment, partly of real wages in response to unemployment, and partly of employment in response to changing real wages; differences in existing institutions and structural policy frameworks accounted for a large part of the differences in these adjustment speeds across countries. The second is a rise in the "equilibrium" rate of unemployment. It is difficult to quantify the effects of changing institutional set-ups and structural policy settings on equilibrium unemployment, and it is also difficult to partition high and/or rising unemployment into a component which is caused by slow adjustment following disturbances and a component which reflects increased equilibrium unemployment.

Evidence from the development of wage shares in several countries supports the idea that the trend increase in unemployment to an important extent represents slow employment adjustment, superimposed on any increase in equilibrium unemployment that may have taken place: by 1990 wage shares had fallen to historical lows in Germany, France, Denmark, Ireland, the Netherlands and Spain, all countries where trend unemployment has gone up in the past. And in most countries econometric estimates of wage equations suggest that the level of unemployment is a more significant determinant of wage increases than its deviation from trend, indicating that trend unemployment has risen by more than equilibrium unemployment and is thus a poor approximation of the latter. However, disinflation is not necessarily assured just because unemployment is above its equilibrium value: when unemployment -- though above equilibrium -- is falling rapidly, inflation could rise. This "speed limit" effect is given some support by econometric work which suggests that wage growth is affected by changes in the rate of unemployment, as well as by its level.

Looking systematically at possible individual causes for a trend increase in unemployment, it would appear that changes in the age-gender composition of the labour force, speed of change in the structure of output and the intensification of international trade and competition have not been important contributors to the observed large increases in trend unemployment, and sometimes may even have tended to reduce unemployment. Similar arguments apply with respect to changes in the attitudes of the social partners and the speed of technical progress. Changes in general social attitudes are hard to quantify and 
therefore it is difficult to identify their contribution to rising unemployment. While high real interest rates caused, inter alia, by continuous budget deficits may potentially have contributed, little evidence is available on such effects. In a few countries rising trend unemployment has been accompanied by a drastic increase in the regional concentration of unemployment, reflecting the lack of regional wage flexibility and low geographic labour mobility. Additional work is needed to assess further the importance of some of these factors and their role in the future evolution of unemployment.

As to the role of structural, especially labour-market, policies in explaining rising trend unemployment, there has indeed been a significant increase in the generosity in various relevant policy areas in many countries, but in most cases it preceded the rapid increase in trend unemployment which started in the seventies. And, from about 1980 onwards, changes have tended to go predominantly in the opposite direction. Nevertheless, it is likely that the adaptation of attitudes to changed labour-market legisiation occurs only very slowly, in which case those earlier extensions of unemployment compensation, minimum wages and employment protection legislation may indeed have led both to some increase in equilibrium unemployment and slowed down labour-market adjustment. The review of the evidence on changes in taxation (both rates and structure) suggests that these are unlikely to account for the massive increase in -- and persistence of -- unemployment, while active labour-market policies, including tight enforcement of job search requirements, seem to have played a significant role in keeping unemployment down in some countries.

In the case of slow labour-market adjustment, structural labour-market policies may account for the trend increase in unemployment even where policy settings did not change: once unemployment has gone up in response to a detrimental demand or supply disturbance, various institutional arrangements, including employment protection legislation, generous unemployment benefits, and -- more generally -- all institutional arrangements reinforcing the distinction between "insiders" (employed persons) and "outsiders" (the -- especially long term -- unemployed) may delay necessary labour-market adjustments. In addition, the speed of adjustment may not be symmetric: while employment reductions in response to negative disturbances may be quite swift, their reversal may take considerable time if insider-outsider mechanisms are important. 
1. Thanks are due, in particular, to Peter Sturm for many comments and suggestions. More generally, this paper is to a considerable extent the result of a joint effort by a team comprising also Andrew Burns, Benedicte Larre, Maitland MacFarlan, Howard Oxley and Mark Walsh. Thanks also go to Sveinbjörn Blöndal, Steve Englander, Mike Feiner, Constantino Lluch, Karl Pichelmann and Jeff Shafer as well as to a number of other OECD colleagues both in- and outside the Economics Department. Isabelle Wanner provided efficient statistical assistance helped by Catherine Chapuis-Grabiner and secretarial assistance was provided by Lyn Louichaoui. The responsibility for all value judgements and remaining errors, of course, rests with the author.

2. The derivation of the trend measures is explained in the Technical Annex.

3. Cf. Elmeskov and Pichelmann (1993).

4. For the case of long-term unemployed, see OECD (1993a).

5. Group-specific unemployment rates may be a misleading indicator of group-related unemployment risks. To give an example, below-average unemployment rates for older persons could, in some countries, be the result of combining a predominantly male older labour force with a low male unemployment risk and a relatively high unemployment risk for older persons.

6. Both unemployment and participation rates for older persons are, on the definitions used in Table 2, affected by statutory retirement ages. This is particularly so for women, who in many countries have lower statutory retirement ages than men. Participation rates by age and sex are not shown in Table 2. For information on these, see OECD (1992).

7. A major problem in identifying differences across countries is lack of comparability of educational or regional classifications. In addition, analysis of these differences can be conducted at different levels of disaggregation, often yielding contradictory results: The synthetisation of many regional or educational unemployment rates into a single summary measure of dispersion also opens up a host of different measurements, often yielding different conclusions concerning both crosscountry differences and trends over time. A main problem in assessing such measures is that the overall unemployment rate differs across countries and has been rising in most, and that $a$ priori, it is difficult to say how one would expect such a difference or increase to be distributed across categories of labour, e.g. should groups-specific unemployment rates rise in proportion to or by the same amount as the national average? Basically, this is the main difference between various summary measures. (This issue is discussed further in Section 3.3.3 below; , see also OECD, 1989).

8. See e.g. OECD (1989).

9. Based on occupational categories, two measures of unemployment dispersion presented in OECD (1992) give conflicting indications on the trends in unemployment imbalance for many countries except Austria and Germany (increasing imbalances), Canada (little change) and Belgium and Finland (smaller imbalances). 
10. These comments and the figures in Tables 4 and 5 refer to Germany before re-unification. The regional dispersion of unemployment rates has greatly increased in post-unification Gerinany, reflecting problems of structural adjustment in the former territory of the GDR.

11. This point is illustrated for the United States by Blanchard and Katz (1992).

12. The average duration has been calculated from unemployment and outflow rates, under steadystate assumptions, implying that the figures may deviate from actually observed average durations. Also, some unemployed experience multiple spells of unemployment which are likely to be counted as individual spells of unemployment. Thus, in some, notably Nordic, countries active labour-market policies may serve to interrupt spells of unemployment, giving a downward bias to average duration and an upward bias to the inflow rate. Similar effects may occur in countries, such as the United States, where short-term movements between unemployment and non-participation, as well as temporary lay-offs, are frequent (Blanchard and Diamond, 1990; Clark and Summers, 1979).

13. The derivation of the trends in Panel D of Figure 3 from the observations in Panels A-C is explained in the Technical Annex.

14. It is worth noting that the focus is on short-run stability of wage inflation. To the extent the latter is affected by both levels and changes of unemployment, short- and long-run NAWRUs will differ (see Section 3.2 below).

15. The proportion of vacancies registered with public employment services is often relatively low and changing over time, with statistics for some countries (United States and Canada) based on the physical size of newspaper advertisements on job vacancies. The latter is the cause for using indices of vacancy rates rather than the vacancy rate itself in Figure 3. Problems of data quality may explain why the trend unemployment rate derived from the Beveridge relationship deviates so much from the other trend unemployment rates in some countries (see the Technical Annex).

16. Because of problems of data availability and comparability the graph is based not on direct figures for capacity utilisation but rather on deviations between actual and smoothed production. To the extent actual production deviates consistently from full-capacity production, this measure may give a wrong impression of capacity utilisation. Nevertheless, based on evidence from the countries that publish a direct measure of capacity utilisation, the trend deviation of output used in the graph provides a good proxy measure of capacity utilisation (see the Technical Annex).

17. Comparing the ranking of countries based on the standard deviation of annual unemployment rate changes with the ranking based on the root-mean-square-deviation of unemployment rates from a Hodrick-Prescott filtered trend (smoothing factor of 50) results in a Spearman rank-correlation coefficient of 0.964. (Since the unemployment rate is trended in most countries, the standard deviation in Table 7 is calculated on the change in the unemployment rate.)

18. Especially important may be the incentives concerning temporary lay-offs, which seem to be prominent in the United States, Canada, Austria and Denmark, short-time working, where special provisions exist in Germany ("Kurzarbeitergeld", cf. Leonard and Schettkat, 1991) and Italy ("Casa Integrazione Guadagni"), and partial unemployment benefit systems as in France and Denmark.

19. With the exception of Finland, these are countries with relatively tight employment protection legislation (EPL), suggesting that such legislation may prompt firms to pursue adjustment of labour input more by variation in hours worked than in the number of persons employed. As noted, however, Spain, a country with tight EPL, also appears to have a high co-variation between 
output and employment. Indeed, the two sets of adjustment seem to add up to an implausible degree of cyclicality of total hours worked for Spain.

20. Austria, thus, is a case where low variability of unemployment is explained by stable output, low responsiveness of employment to variations in output and a highly flexible labour force. Spain may be the best example of the opposite situation where moderately volatile output is combined with a strong employment response and a relatively inflexible labour force. For a graphical presentation of the deviation from trend in employment and the labour force in OECD countries, see Elmeskov and Pichelmann (1993).

21. In this case, as well as in the case of the output-employment relationship, the direction of causality is not given a priori. Formal causality tests do not yield uniform results across countries, but the pro-cyclical movement of real wages suggests that the dominant causal link runs from employment to the labour force. Within the framework of real business cycle theory, productivity shocks could, however, trigger both pro-cyclical real wages and a causal link running from labour force to employment. The direction of causality is discussed more thoroughly in Elmeskov and Pichelmann (1993).

22. The first effect corresponds to a shift of the labour supply schedule, whereas the latter represents a movement along a given supply curve.

23. Estimated across the sixteen countries where all indicators are available in Table 7, the following equation in most cases gave the signs predicted in the text though not always at high levels of significance:

variability of unemployment rate $=0.85+0.28 *$ variability of output

$(0.23)(0.20)$

$+0.05 *$ employment responsiveness $-0.84 *$ labour force responsiveness.

$(0.27)$

Standard errors are given in parentheses below estimated coefficients. Using indicators calculated over a more recent period, Elmeskov and Pichelmann (1993) obtain more significant coefficients and also find a separate role for an indicator of real wage flexibility.

24. The cyclicality of the unemployment rate in the United States may to some extent reflect the widespread use of temporary lay-offs, in many cases as part of an implicit contract between firms and employees to take advantage of the unemployment-insurance system.

25. There is a significant negative relationship between the cyclical responsiveness of the labour force to changes in employment, one of the determinants of unemployment variability, and the trend rise in unemployment. As there is nothing which suggests that trend growth of the labour force has been lower in countries that have a highly cyclical labour force, this cannot be interpreted as unemployment being hidden in countries with a highly responsive labour force. On the contrary, countries with high unemployment rates usually also have relatively low participation rates (Elmeskov and Pichelmann, 1993).

26. This follows an approach applied earlier by Barro (1988); the appropriateness of this test procedure may be questioned, with the unit-root results discussed above showing that unemployment rates behave like an integrated process in many countries. However, authors using longer time series than used here, including Barro (1988) and Bean (1992) have found conflicting evidence on whether unemployment rates are integrated, and over the very long run the unemployment rate is evidently bounded by 0 and 1 . The length of the moving-average process has been determined by adding lags until they were no longer significant at the 5 per cent level. It might be argued that the MA part of the process should be taken into account in the indicator of persistence, but here it was chosen to replicate the procedure used by Barro (1988). 
27. Finland, Iceland, Portugal and Switzerland are the only other countries where the AR(1) coefficient deviates by more than one standard deviation from unity. However, the "model" is very poorly determined for France, Italy and Ireland.

28. When the concept of a "natural rate" of unemployment was originally introduced, this rate was thought of as constant. Rising unemployment in the 1970s and through the 1980s, and the experience that declining unemployment led to re-acceleration of wages even though the level of unemployment was still above previous troughs, have cast doubt on the stability of the natural rate.

29. The type of framework used to describe the development of unemployment is set out formally in Bean (1992a), Layard et al. (1991) and Lindbeck (1992), and described more informally in Blanchard and Summers (1988).

30. If mark-ups are independent of activity, the labour demand/price-setting schedule may, in the long run when the capital stock is flexible, entail a fixed level of the real wage, at which any employment level may be consistent with firm behaviour.

31. An element of uncertainty is introduced into calculations of the functional income distribution by the imputation of labour income for the self-employed. Normally, average compensation is used as the imputed labour income of self-employed. If alternatively an imputation is made, so that the labour incomes of self-employed gradually rise from a very low level towards the same level as wage earners, the conclusion remains broadly unchanged, i.e. a sharp trend break in income distribution around 1980 remains. An imputation of this kind, though not necessarily of the arbitrary magnitude chosen in Figure 5, may seem a reasonable assumption for countries where self-employment has changed from consisting predominantly of agricultural smallholders to mainly comprising highly-paid professionals.

-32. In the Cobb-Douglas (CD) case this is simply done by using the average wage share as the output elasticity of labour. In the constant elasticity of substitution (CES) case, the average of the yearly calibrated distribution parameter for labour has been used, and labour efficiency has been calculated based on the production function residual from a $C D$ function, transformed into labour efficiency using the labour share and smoothed using a Hodrick-Prescott filter. While the residual from a CD function may not be strictly consistent with the marginal product calculated from a CES function, experimentation has shown that differences in labour efficiency from variations in the assumed elasticity of substitution are small.

33. Since this was the period used for calibration of production-function parameters it is, as such, not surprising. What is of interest is the relative development of the curves -- not their level. Other authors using a different base period have found big positive wage gaps in the 1970s (e.g. Bruno and Sachs, 1985).

34. If Figure 6 had been constructed on the basis of the same considerations as the alternative imputation of labour income to the self-employed in Figure 5, the messages of Figure 6 would have stayed essentially unchanged.

35. That is, the second specification implies that the relationship between unemployment and real wages is affected neither by a one-time inflationary impulse nor by a permanent shift in inflation.

36. Evidently many different trends can be constructed, giving the exercise a certain arbitrary character, but as discussed in Part 2 of the paper, various trend concepts tend to give relatively uniform results. Here, trend unemployment was estimated using a quadratic time trend including also the log of time. Egebo and Englander (1992) found broadly uniform results from 
experimenting with a number of different trend terms in wage equations for a number of ERM member countries.

37. Estimates have also been performed with an estimate of trend growth of labour efficiency added to the specification. Since this variable was often either insignificant or came out with unreasonable coefficients, these results are not reported.

38. While the deviation from trend is generally insignificant it, nevertheless, in most cases comes in with the right sign.

39. Andersen (1992) found significant hysteresis effects for these countries, except Turkey for which he presents no estimates, and in the cases of the United Kingdom, Sweden and Austria, he finds only relatively weak effects of unemployment levels on wage formation.

40. The signs and significance of effects from unemployment changes on wages suggest a reason why, if unemployment was above long-run equilibrium in a number of countries in the late 1980s, inflation nevertheless began to increase. With unemployment rates in some countries falling rapidly, the effects from unemployment changes more than offset the downward pressure coming from the level of unemployment.

41. The mechanisms at work are not simple. To give an example: a reduction in the group size of young workers with frequent job changes and associated spells of transitory unemployment may, ceteris paribus, reduce unemployment. However, if reduced youth unemployment leads to higher wage pressure, equilibrium unemployment will not have been reduced correspondingly. It may still be reduced, though, if wages for individual demographic groups are convex functions of group-specific unemployment rates. Generally, in this case, a fall in unemployment among a high-unemployment group will lead to an increase in wages that can be offset by a numerically smaller increase in unemployment for other (low-unemployment) groups. Even assuming non-age specific wage rates, if the size of a sub-group with above-average unemployment and below-average weight in wage determination is being reduced, the overall equilibrium unemployment rate should fall; cf. also Weithers and Sullivan (1991).

42. For most countries, 5-year age groups were used but for some countries and age ranges only 10-year groups were available. The analysis has also been performed with 1980 as the base year, yielding essentially identical results.

43. Scarring refers to permanent effects on a person's chances of getting a job and on his or her wage resulting from a period of unemployment. It may occur, e.g. if employers use previous experience of unemployment as a screening device when hiring new recruits. Regression results linking cohort-specific unemployment rates to either overall or gender-specific unemployment rates at the time of labour-market entry, may suggest that such effects are present for some countries, though the results are generally weaker than when the cohort-specific unemployment rate at the time of entry is used as a regressor (see the Technical Annex). Among the exogenous features of the cohort, the impact of size was discussed in OECD (1986), where it was found that large cohorts were disadvantaged with a combination of both higher unemployment and lower earnings. The persistence of these effects could, in principle, be caused by scarring.

44. Failure to correct his measure of structural change for cyclical influences was one of the main criticisms of the work presented in Lilien (1982), which initiated a number of attempts to quantify the effects of sectoral shifts on overall unemployment rates. Papers which corrected the Lilien approach for cyclical variation have generally ended up with smaller or no effects on aggregate unemployment levels (Abraham and Katz, 1986; Charette and Kaufmann, 1987). The cyclical nature of job losses and job creation has been documented for the U.S. manufacturing sector in 
Davis and Haltiwanger (1990) who found that job creation was a relatively steady process whereas the cyclical variability of unemployment mainly reflected variations in job destruction.

45. The indicators of sectoral change were constructed using the OECD International Sectoral Database (ISDB), whereas the indicators of regional change were based on material collected for OECD (1988) and OECD (1989). The two indicators used in both the sectoral and regional dimension are, respectively, the relative change in total employment accounted for by the sectors/regions with declining employment (shake-out) and the (weighted) standard deviation of sector/region-specific employment growth rates (turbulence). Due to data constraints, the sectoral and regional classifications differ across countries. For further explanation, including the procedure of cyclical adjustment, see the Technical Annex.

46. Averages over decades, presented in Jackman et al. (1991), tend to give the same impression over an even longer time period. Based on shorter series and a more aggregate but common sectoral classification across countries, the evidence on cross-country differences in levels of sectoral turbulence points to relatively high and maintained turbulence in Australia and Canada, much lower levels in most EC countries and significant falls in the Nordic countries.

47. The cyclical adjustment not being trivial in this case, the result could, of course, also reflect errors related to the procedure of cyclical adjustment. It should also be noted that the results using the turbulence indicators are much less suggestive of a link to actual unemployment rates (see the Technical Annex).

48. The effects found are generally quite large, to the point of being implausible if the steady-state implications are calculated which, however, should be seen against the background of the very simple specification.

49. Podgursky (1992) presents evidence for the United States that during the 1980s there was a strong downward trend in rates of job displacement in the manufacturing sector while the trends differed across service sectors, but with an overall much smaller fall in the rate of displacement.

50. Glyn and Rowthorn (1988) present cross-country evidence suggesting that unemployment is more affected by changes in industrial employment than by changing employment elsewhere in the economies.

51. There is evidence from Italy, that previous regional wage differences have been significantly reduced, with wages in Southern Italy following wages in Northern Italy without regard for local labour market conditions (Kostoris, 1992). This may be one explanation for falling mobility. Other evidence points to the rise in national unemployment, also affecting the North, as the main cause (Attanasio and Schioppa, 1991). In the context of German reunification, one objective for relatively rapid alignment of eastern with western wages was to reduce migration pressures.

52. Taxes and charges in connection with fixed property transactions may to some extent be seen as taxes on mobility. In countries such as Italy, France and Belgium, transaction taxes and compulsory charges can amount to around 10 per cent or more of the property value. Lack of competition and regulatory barriers concerning real estate agents in some countries allow them to charge very high fees.

53. A discussion of how to define mismatch is contained in Schioppa (1991a).

54. OECD (1989) also presents evidence supporting the notion that relative unemployment rates should be given a higher weight than differences between absolute unemployment rates. In the context of wage setting this may be more obvious. If Phillips curves in individual sub-markets are non-linear, and assuming an initial uneven distribution of unemployment rates, then the same 
absolute unemployment rate increase across all categories would lead to changing relative wages, indicating a change in relative scarcity of different kinds of labour. As a special example, with a log-linear Phillips curve, the same proportionate unemployment rate increase would leave relative wages unchanged. Assuming individual Phillips curves to be linear would, however, reverse this argument. Also, looking at mismatch from a perspective of labour demand may support the use of absolute unemployment rates, the argument being that when employment changes by $x$ per cent, "neutrality" would imply that individual groups should experience the same change and therefore that disaggregate unemployment rates should all change by approximately $x$ percentage points.

55. The limitations of the mechanical decomposition should be kept in mind. For example, the conclusion concerning the contribution of net exports to employment growth may reflect behavioural reactions, including policy changes, in response to rising import penetration or weak export performance. Such reactions could show up as a smaller domestic demand contribution to employment growth.

56. For the definition of low-tech, see OECD (1992b).

57. Revenga (1992), in a study of the impact from the real appreciation of the U.S. dollar in the first half of the 1980s, finds an effect from import competition on industrial wage dispersion. Her study, though ignoring skill differences, also suggests a reason why most demand-related development of wage dispersion seems to arise from the intra-industry distribution. The effects of increased import competition fall predominantly on the industrial employment structure rather than the industrial wage structure, which the author interprets as a sign of high inter-industry labour mobility. A possible interpretation of this evidence would be that trade may cause as much dislocation as technical progress but that this dislocation is more easily dealt with through inter-industry employment shifts, while technical progress requires inter-skill shifts, which are more difficult to implement. This seems, however, to conflict with evidence quoted in Abowd and Freeman (1990) that workers dislocated by trade appear to have greater difficulty finding work than workers displaced for other reasons.

58. Abowd and Lemieux (1991) presents evidence for Canada that increased import competition reduces the quasi-rent component of wages. Moreover, it seems that wages respond more than employment to changes in either export or import prices -- a result which seems to contrast with the one for the United States in Revenga (1992). Also using Canadian data, Christofides and Oswald (1991) find evidence of rent sharing, but do not discriminate between various hypotheses explaining such rent sharing. Using a bargaining framework, Nickell et al. (1992) present evidence based on a sample of British manufacturing companies that relative firm-specific wages are rising with the firm's product market power, independently of the degree of unionisation in the firm.

59. Wood assumes inter alia that much of the North-South trade in manufacturing is in "noncompeting" goods (a misnomer, characterising goods where imports from the South have completely replaced production in the North), and that income levels are not affected by trade.

60. The following quotation may serve as an illustration: "This structural shift has left a residue of poorly educated, unskilled male labour whose market value has fallen sharply: These are the groups which have been hit hardest by unemployment. Countries have been affected in different ways, and their policy responses have differed. In the US, where wages are very flexible, the real wages of the lowest-paid 10 per cent of workers have fallen by 30 per cent since 1970 , while the wages of college graduates have grown." ... "Continental Europe has taken a different route. The relative rigidity of wages, and high unemployment benefits, have prevented unskilled real wages 
from falling. But employers have been unwilling to hire the unskilled at those wages. Unskilled men subsist on state benefit." Edward Balls, Financial Times, 15 May 1992.

61. Different sources give slightly different results as regards both levels and changes over time, but the overall tinrust of the results seems to be the same, see e.g. Freeman (1988). It is worth noting that wage dispersion cannot be seen in isolation from the dispersion of labour productivity.

62. In almost all countries, narrowing gender pay differences, be it as a result of a relative upgrading of female labour quality, legislated wage equalisation, or reduced discrimination, tended to reduce wage dispersion. It is noticeable that increased equality of wages across gender has occurred in a period when the female labour supply was expanding strongly in many countries. The countries covered in Table 12 are split in two almost equally large groups as to whether the relative unemployment rate for women compared to men rose or declined over the last two decades.

63. There is also some evidence that the return to work experience (in the form of higher wages) has risen through the 1980s, particularly among weakly qualified labour (Davis, 1992; Bound and Johnson, 1992). Finally, it appears that the widening of wage differentials during the 1980 s to a large extent occurred within, in contrast to across, educationalexperience/gender groups (Davis, 1992; Edin and Holmlund, 1992; Grubb and Wilson, 1992).

64. For the United States, Bound and Johnson (1992) estimate a common elasticity of substitution of 1.75 across a number of categories of labour. Katz and Murphy (1992) find an estimate of 1.41 between college and high school educated labour. For Denmark, Risager (1992) estimates an elasticity of substitution between skilled and unskilled labour of between 1.3 and 1.8 depending on the estimation method and taking into account that raw material prices may affect the choice between different types of labour even at unchanged relative wages. Similar, or in one case higher, elasticities are found in estimates for individual production sectors.

65. For the United States, Juhn et al. (1991) find results suggesting that wage elasticities of labour supply are particularly high at the bottom end of the wage-scale.

66. Even if group-specific unemployment rates do not indicate any imbalance, lack of intra-group relative wage flexibility could still lead to higher overall unemployment. This would be the case if reduced inter-person and inter-job wage differentials led to less self-selection by applicants to vacancies, increasing the screening costs of firms (Flanagan, 1988). It is also the case if more standardised wage rates decrease the possibilities of the unemployed to price themselves back into employment, thereby enhancing the insider-outsider distinction. However, as noted above, intragroup wage dispersion has seemingly been on the increase over the 1980 s.

67. In the case of youth unemployment, this may reflect special labour market measures aimed at allèviating it.

68. Kostoris (1992) specifically relates this to the pattern of relative wage setting.

69. In the case of France, the effect of the statutory minimum wage on relative youth wages has been investigated by Bazen and Martin (1991). Davis (1992) notes that the bottom half of the French wage distribution is much more compressed than in other countries: Comparing compression in the upper and lower halves of the wage distribution across countries in 1986, the author finds that the ratio of the relative differences between the median wage and, respectively, the ninth and the first decile of the wage distribution varied from 0.63 in Canada, 0.72 in the United States, 1.12 in the United Kingdom, 1.13 in Australia to 1.67 in France. A comparable figure from Sweden is about 1.4 (derived from diagram in Edin and Holmlund, 1992).

70. This has been discussed in OECD (1990b) and OECD (1993). 
71. Figures are quoted from Layard et al. (1991), Table 6, p. 98. The authors also estimate a cross-country time-series equation for unemployment, where the main explanation for OECD-wide increasing unemployment is a dummy purportedly capturing increased militancy from 1970 onward.

72. Causality tests reject the restriction that private-sector wages have no influence on public-sector wages for the United States, Japan, Italy, the United Kingdom, Denmark, Finland, Norway, Portugal, Spain and Switzerland and only reject the restriction that public-sector wages have no influence on private-sector wages in the case of Australia (see the Technical Annex). Results are unclear in the case of Sweden. However, Holmlund and Ohlsson (1992) in a recent study on Swedish data find clear evidence of influence from private-sector wages to public-sector wages but also find some signs of causality running from central-government wages to private-sector wages.

73. The measure of real-wage rigidity is defined as the rise in the unemployment rate which is necessary to offset the impact on wages of a rise in consumer prices by 1 percentage point (OECD, 1989a).

74. Whereas the initial focus was on the degree of corporatism, recently, more stress has been put on the degree of centralisation of wage bargaining and the degree of co-ordination, especially on the employer side. All of the related indicators are necessarily "soft" (i.e. difficult to quantify) which has led some authors to propose using indicators that are empirically observable (Freeman, 1988). The "softness" of the indicators has also led to disagreement as to the proper ranking of countries.

75. The literature is unclear as to the nature of the relationship between the various features of wage bargaining systems and the speed and extent of wage adjustment. Some argue that it is monotonic, e.g. more centralisation of wage bargaining is always associated with enhanced real wage flexibility. The dominant tendency seems, however, to be different, arguing that wage bargaining systems which are either very corporatist/centralised/co-ordinated or at the opposite end of the spectrum do best in terms of flexibility of aggregate real wages, while bargaining systems that are in-between with some market power for the participants but no incentive for internalising the unemployment effects of bargaining do worst. In part, this disagreement may reflect disagreement on the proper ranking of countries with respect to these criteria. Thus, Calmfors and Driffill (1988) illustrate the prevailing disarray by showing five different rankings based on just the centralisation aspect. Calmfors (1993) argues that the relative merits of the different systems may depend on the overall inflation rate, with very centralised systems requiring a certain level of inflation to perform well. That study contains a more detailed presentation of all the issues involved as well as a number of references to empirical work.

76. In both cases, insider effects are gauged by the influence coming from lagged employment on wages.

77. Some evidence confirming this picture is presented in the Technical Annex. See also OECD (1989a).

78. The Solow residual refers to the residual part of economic growth after the contributions from increased input of production factors, usually capital and labour, have been taken into account. It corresponds to the concept of (change in) total factor productivity.

79. The transmission mechanism could work as follows: current employment raises the probability of being employed in the future, but with slower productivity and real-wage growth the value of this link is reduced. As a result, there may be less restraint on wage demands and, consequently, higher equilibrium unemployment. Estimating Phillips-curve wage equations for 19 OECD countries, Manning (1992) finds that the slowdown in productivity, requiring a decline in 
equilibrium real-wage growth, can explain a significant part of the rise in unemployment between the periods 1957-65 and 1977-85. It should be noted, though, that to the extent the real interest rate is reduced in step with technical progress, the effect on discounted future income is neutralised. Thus, a slowdown in steady-state growth would not have the above effect (Manning, 1992).

80. Aghion and Howitt (1991) present a model where both the effects of technical progress on friction and on incentives to achieve rapid matching are present and show that the effect of technical progress on unemployment may change sign, becoming negative when growth is above a certain threshold.

81. To some extent this depends on production technology, with a Cobb-Douglas function always associated with unchanged equilibrium factor-income shares, independently of the size of capital costs. Temporary effects may, however, be present if a putty-clay vintage production function with CD-technology for the new vintage is combined with a wage bargaining framework (Darby et al., 1992).

82. Higher real interest rates may also lead to permanently increased wage pressure and, therefore, a rise in equilibrium unemployment. This may result because the return from current employment is implicitly being reduced by higher real interest rates. Thus, current empioyment usually increases the probability of future employment, but higher interest rates reduce the present value of this link. However, if real interest rates rise because steady-state growth has increased, then the income from future work will increase in line with the interest rate, neutralising the impact on wage pressure, the obverse to the argument made in footnote 79 . It has also been argued that higher real interest rates reduce the present value for firms of having a large stock of customers or a stock of operational employees, reducing firms' labour demand at given real wages (Phelps, 1992).

83. It has been argued that such use of the benefit system may raise equilibrium unemployment also indirectly through the heavy workload which the many short spells create for the public agencies involved, thereby effectively claiming resources which could have been used in active measures targeted at more difficult "cases".

84. To the extent persons in receipt of benefits are constrained by the administration of the benefit system to search more intensely for jobs, this could speed up adjustment.

85. In some countries, changing tax status of unemployment benefits may also have affected the recorded generosity indicator. Moreover, to the extent behaviour is changed by changes in parameters of the benefit system, Figure 13 may give misleading results. For instance, if an extension of maximum duration of benefits leads to increased average duration of unemployment, the measure reported in Figure 13 changes only to the extent that persons previously cut off from benefits but still unemployed become eligible for benefits, whereas effects on duration within the maximum limit will affect both nominator and denominator in equal proportions.

86. Elasticities of unemployment duration with respect to replacement rates have typically been well below 1 for estimates based on data from the United States and the United Kingdom. Studies based on data from the United States and Canada have indicated that an increase in maximum duration of one week could increase average duration by 0.1 to 0.3 weeks with most results clustered around the lower end of the range.

87. It has been suggested that at least as regards the effect of the benefit level, a reason for the contrast between U.S. and European results may be that the impact of changing the replacement rate falls over the duration of the unemployment spell (Atkinson and Micklewright, 1991). 
Studies for both the United States and Denmark have found positive effects of the replacement rate on the likelihood of becoming unemployed.

88. An example is the cross-country estimation of unemployment rates in Layard et al. (1991), which indicate that increasing the maximum duration by one year could increase the average unemployment rate by 0.9 percentage points and raising the replacement ratio by 10 percentage points could increase the unemployment rate by 1.7 percentage points. While these results may not seem out of line with the North American results from panel data, they are out of line with the lack of results from European estimations on panel data.

89. Heylen (1991) demonstrates the existence of such co-variation and proposes some explanations for this observation.

90. - A particular problem may arise when replacement rates or other aspects of generosity differ considerably across the wage distribution. This may be the case when a high statutory replacement rate is combined with a low maximum amount. Such a system could seriously affect the wage structure.

91. In the case of women, this tendency has been offset by increasing cohort-specific participation rates so as to generate rising or only slightly falling age-specific participation rates for persons close to retirement age.

92. This includes the evidence presented in Table 7, where e.g. Italy, which has very stringent EPL, comes out with low employment responsiveness while the United States, which has little general legislation, comes out with high employment responsiveness. The impact of EPL on cyclical employment variations is not likely to be symmetric. Thus, during a cyclical downturn the number of voluntary quits is likely to fall, implying that firing restrictions become a more binding constraint than in a cyclical upturn. Adjustment speeds are, therefore, likely to be lower when unemployment is high (Blanchard and Summers, 1988).

93. An overview of the literature is presented in Buechtemann et al. (1991).

94. The argument has been made that, on the other hand, EPL by standardising employment contracts may lead to lower transaction costs related to contracting (Williamson, 1992). In addition, EPL may positively affect work effort, incentives for knowledge sharing and investment in training.

95. Appearances may, however, deceive in this area. Examples are the Italian system of support for temporary lay-offs, and the use of civil law suits to claim damages for unwarranted dismissal in the United States. More recently, in 1988, some general rules have been introduced in the United States concerning notice periods for major lay-offs and plant closings.

96. The effects of this approach are uncertain. Thus, it has been argued in the case of Spain that insiders to wage bargaining, who exert a dominant influence on wages; : have seen their job security increased as a result of the use of temporary contracts because persons on such contracts now act as a buffer in times of weak demand. As a result, the wage pressures from the group of insiders may have increased (Bentolila and Dolado, 1992).

97. See e.g. Heylen (1991).

98. Minimum wages may also prevent one way to soften the impact of EPL, which is to agree on a wage contract which contains a low-wage probation or training period (or more generally, strong seniority effects), so that the employee in the beginning of his/her tenure is awarded less than his/her marginal product. The prevention of such contracts may also increase outsider ineffectiveness, slowing down adjustment following shocks. 
99. The sharp fall in relative youth unemployment in France in the second half of the 1980s, despite a broadly unchanged relative minimum wage, can be ascribed to several factors including inter alia the increased number of young workers exempted from the minimum wage and an increasing number of labour-market measures aimed at this group.

100. Income taxes often have progressive elements, indirect taxes as e.g. VAT are levied not only on labour use but on the value added, while social security contributions are levied on both employers and employees and often contain fixed elements (e.g. per worker or per hour contributions as opposed to wage-related contributions) which may entail different implicit contribution rates across heterogeneous labour-market groups.

101. Tax reforms over the 1980 s generally reduced marginal tax rates while preserving a broadly unchanged tax pressure. Conceivably, this could lead to lower unemployment, but the effects are not likely to be major.

102. Two elaborate international studies have recently reached this conclusion (Andersen, 1992 and Kostoris, 1991).

103. The role and effects of active labour market policies are discussed in OECD (1993a).

104. Results reported in Heylen (1991) suggest that countries with high spending on active labour market policies tend to have a lower incidence of long-term unemployment. This may be interpreted as such policies "empowering" the outsiders so as to better compete for jobs, but it could also just reflect that in countries with many active labour-market measures, unemployment spells tend to be broken up.

105. See Edin and Holmlund (1992a) for an overview of such results. The authors themselves, however, reach the opposite conclusion. 
Table 1. Unemployment rates

$\begin{array}{cccc}\text { Average } & \text { Average } & 1992 & \text { Memorandum: } \\ 1960-64 & 1985-89 & & \text { Change } 1960-64 \text { to } \\ & & & 1985-89 \\ & \text { Per cent } & & \text { Percentage points }\end{array}$
(1)
(2)
(3)
(2)-(1)

\begin{tabular}{|c|c|c|c|c|}
\hline \multirow[b]{2}{*}{ United States } & \\
\hline & 5.7 & 6.2 & 7.4 & 0.5 \\
\hline Japan & 1.4 & 2.6 & 2.2 & 1.3 \\
\hline Germany & 0.4 & 6.3 & 4.7 & 5.9 \\
\hline France & 1.4 & 10.1 & 10.3 & 8.8 \\
\hline Italy & 4.8 & 11.6 & 11.2 & 6.8 \\
\hline United Kingdom & 1.7 & 9.6 & 10.1 & 7.9 \\
\hline Canada & 6.0 & 8.2 & 11.2 & 2.3 \\
\hline Australia & 2.1 & 7.5 & 11.0 & 5.4 \\
\hline Austria & 2.0 & 3.4 & 4.0 & 1.5 \\
\hline Belgium & 2.2 & 11.0 & 9.8 & 8.8 \\
\hline Denmark & 1.5 & 8.5 & 10.9 & 7.1 \\
\hline Finland & 1.4 & 4.7 & 12.4 & 3.3 \\
\hline Greece & 5.3 & 7.5 & 9.4 & 2.2 \\
\hline Iceland & 0.1 & 0.9 & 2.3 & 0.7 \\
\hline Ireland & 5.1 & 16.9 & 17.0 & 11.9 \\
\hline Netherlands & 0.4 & 8.7 & 5.6 & 8.4 \\
\hline New Zèaland & 0.1 & 4.9 & 10.9 & 4.8 \\
\hline Norway & 1.7 & 3.0 & 6.2 & 1.2 \\
\hline Portugal & 1.8 & 7.1 & 4.7 & 5.3 \\
\hline Spain & 2.3 & 20.0 & 17.9 & 17.7 \\
\hline Sweden & 1.3 & 1.9 & 5.2 & 0.6 \\
\hline Switzerland & 0.0 & 0.6 & 2.8 & 0.6 \\
\hline Turkey & 5.0 & 10.3 & 11.8 & 5.3 \\
\hline
\end{tabular}

Source: OECD Analytical Database. 


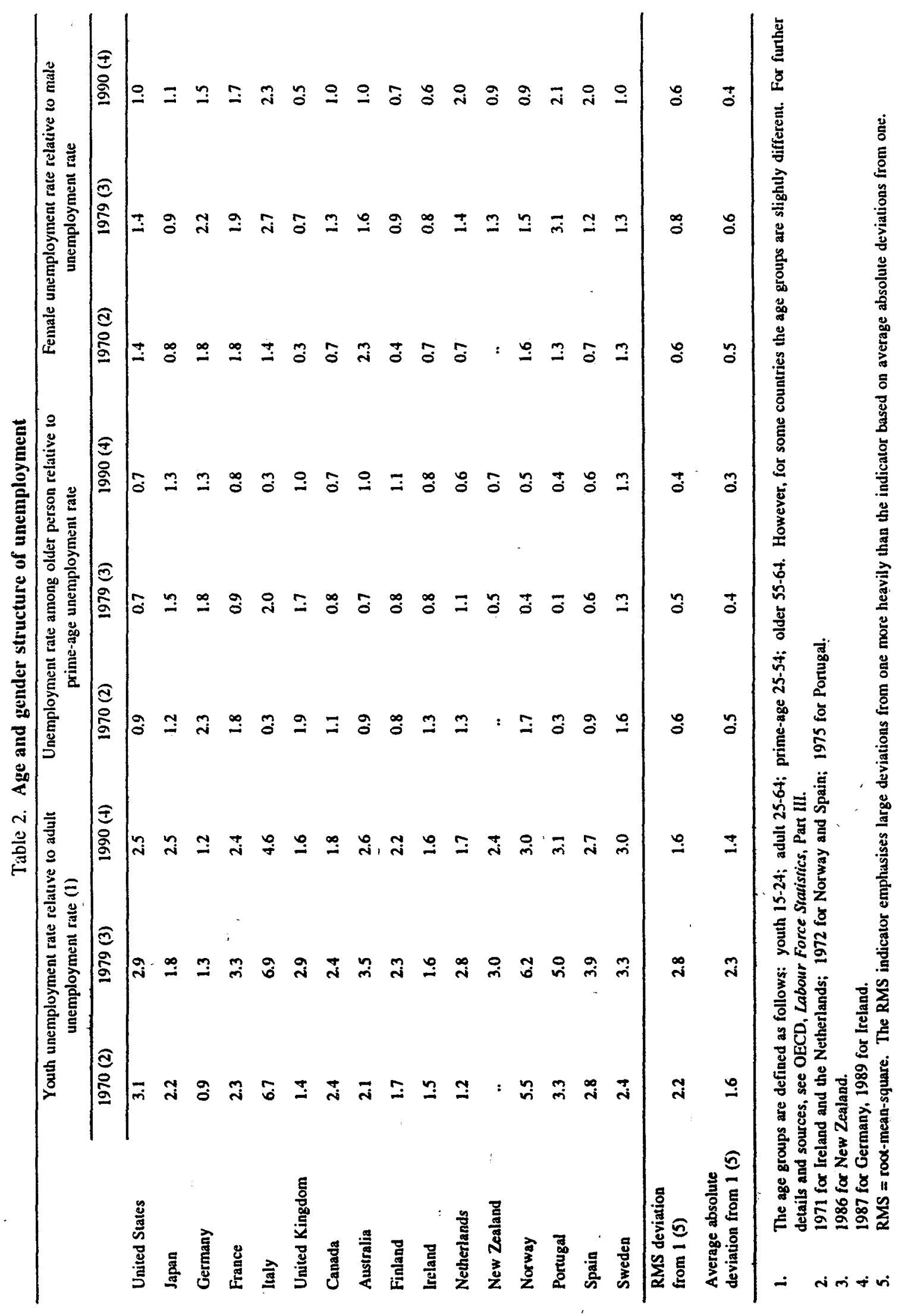




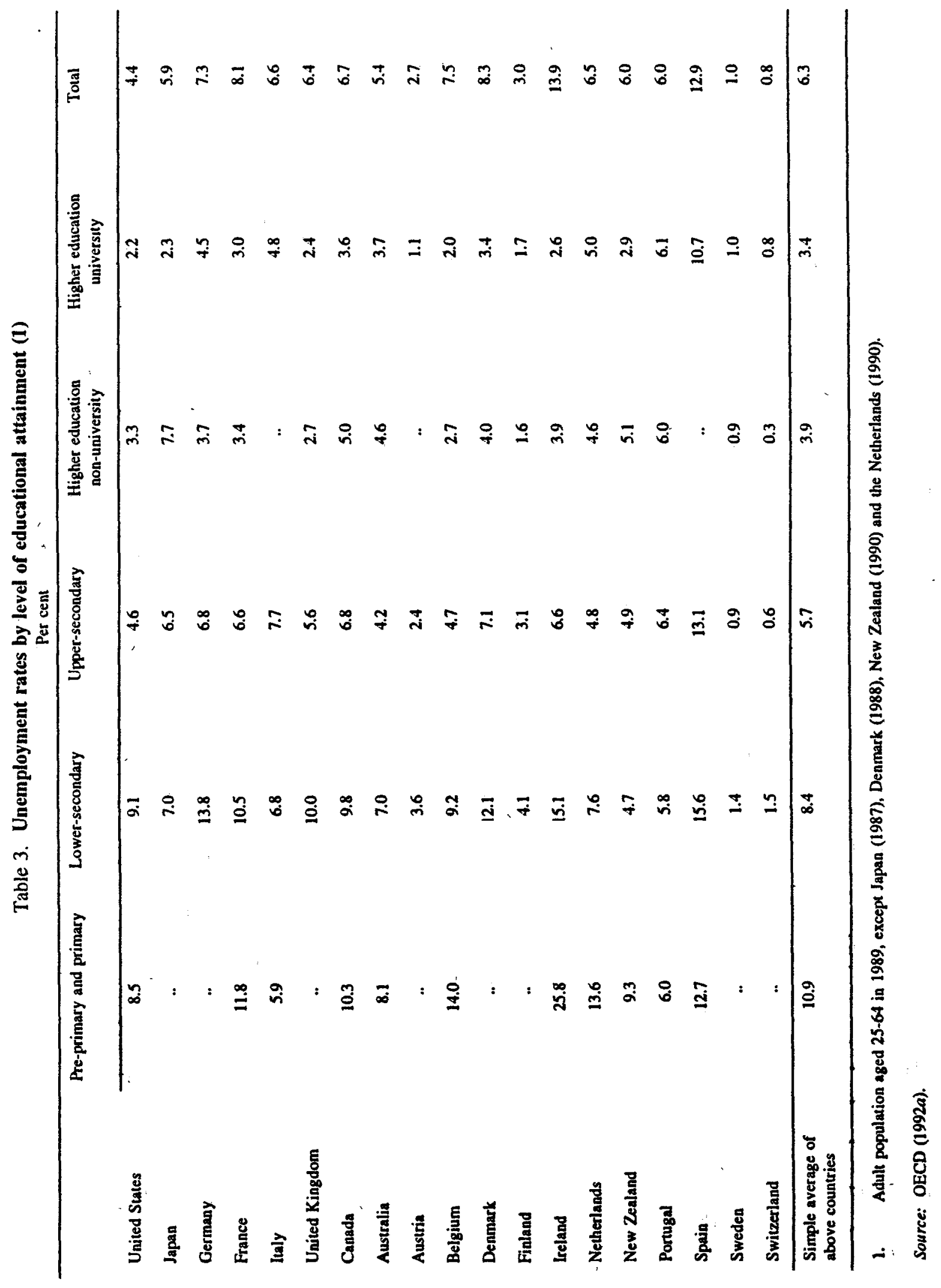




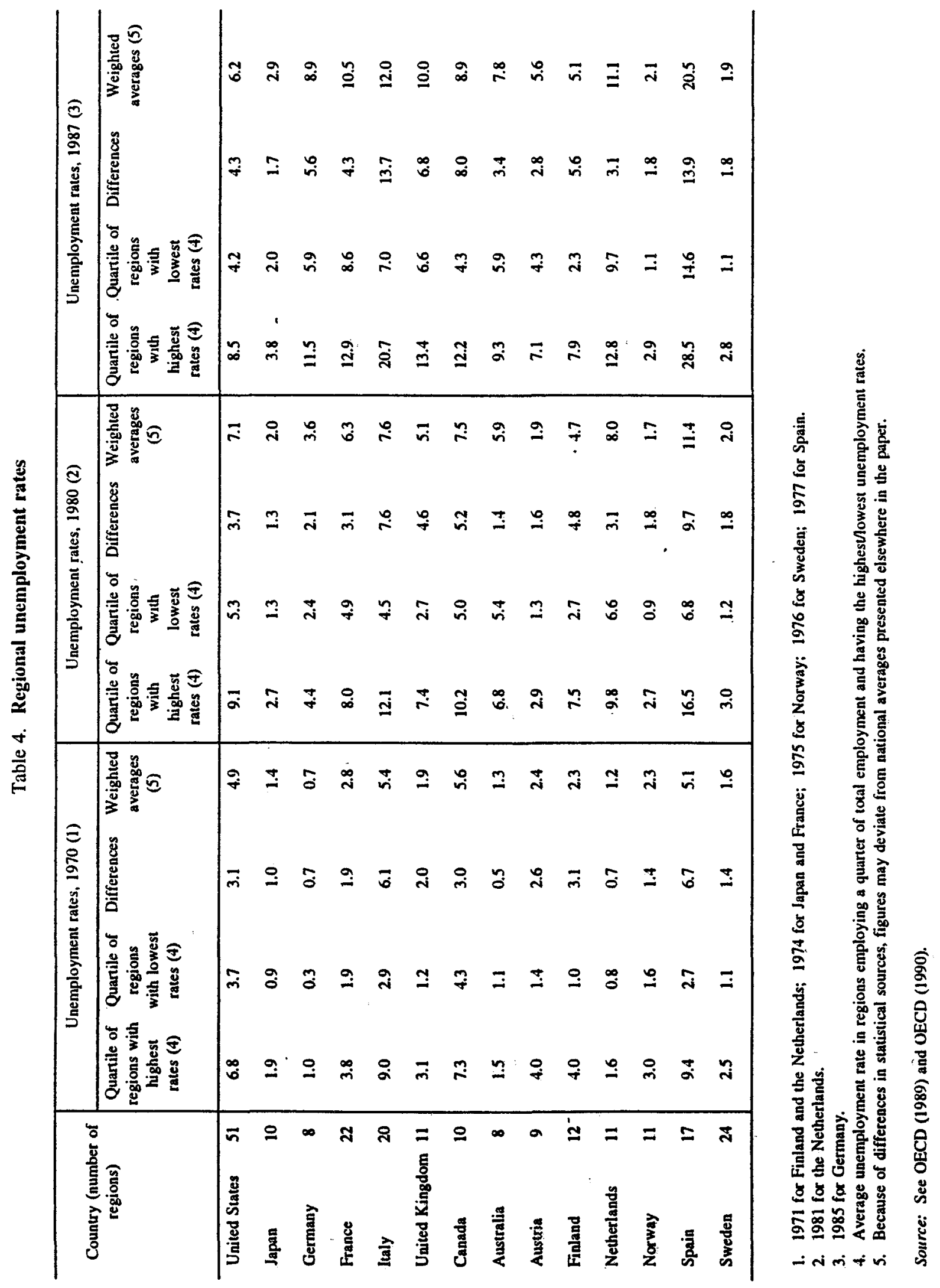


Table 5. Summary measures of regional unemployment dispersion

\begin{tabular}{lc|ccc|ccc}
\hline \multirow{2}{*}{$\begin{array}{c}\text { Country (number of } \\
\text { regions) }\end{array}$} & \multicolumn{2}{c|}{$\begin{array}{c}\text { Coefficient of variation (1) of } \\
\text { regional unemployment rates }\end{array}$} & \multicolumn{3}{|c}{$\begin{array}{c}\text { Standard deviation (1) of } \\
\text { regional unemployment rates }\end{array}$} \\
\cline { 3 - 8 } & & $1970(2)$ & $1980(3)$ & $1987(4)$ & $1970(2)$ & $1980(3)$ & $1987(4)$ \\
\hline United States & 51 & 0.26 & 0.22 & 0.28 & 1.27 & 1.59 & 1.73 \\
Japan & 10 & 0.28 & 0.26 & 0.23 & 0.38 & 0.53 & 0.67 \\
Germany & 8 & 0.39 & 0.24 & 0.26 & 0.26 & 0.86 & 2.33 \\
France & 22 & 0.27 & 0.19 & 0.17 & 0.75 & 1.21 & 1.75 \\
Italy & 20 & 0.46 & 0.43 & 0.47 & 2.49 & 3.21 & 5.60 \\
United Kingdom & 11 & 0.42 & 0.34 & 0.27 & 0.82 & 1.73 & 2.70 \\
Canada & 10 & 0.24 & 0.29 & 0.30 & 1.35 & 2.16 & 2.70 \\
\multirow{2}{*}{ Australia } & 8 & 0.25 & 0.12 & 0.17 & 0.36 & 0.71 & 1.33 \\
Austria & 9 & 0.52 & 0.46 & 0.21 & 1.27 & 0.85 & 1.19 \\
Finland & 12 & 0.55 & 0.44 & 0.43 & 1.23 & 2.05 & 2.21 \\
Netherlands & 11 & 0.25 & 0.16 & 0.12 & 0.29 & 1.29 & 1.37 \\
Norway & 11 & 0.24 & 0.42 & 0.35 & 0.54 & 0.74 & 0.72 \\
Spain & 17 & 0.55 & 0.34 & 0.27 & 2.81 & 3.87 & 5.48 \\
Sweden & 24 & 0.41 & 0.40 & 0.38 & 0.66 & 0.79 & 0.73 \\
\hline Average & & 0.36 & 0.31 & 0.28 & 1.03 & 1.54 & 2.18 \\
\hline & & & & & & & \\
\hline
\end{tabular}

1. Weighted by regional labour force.

2. 1971 for Finland and the Netherlands; 1974 for Japan and France; 1975 for Norway; 1976 for Sweden; 1977 for Spain.

3. 1981 for the Netherlands.

4. 1985 for Germany.

Source: See OECD (1989) and OECD (1990). 


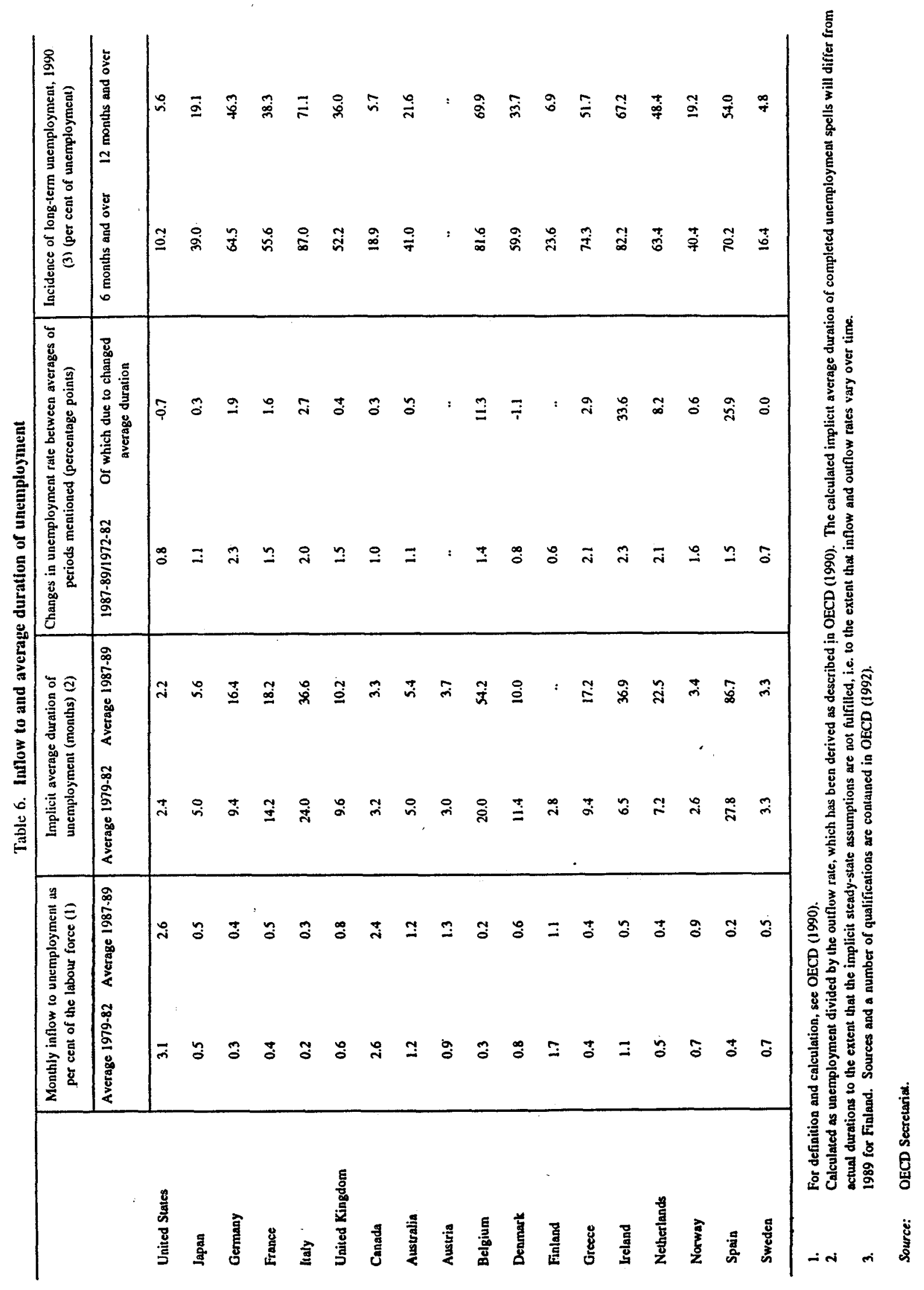




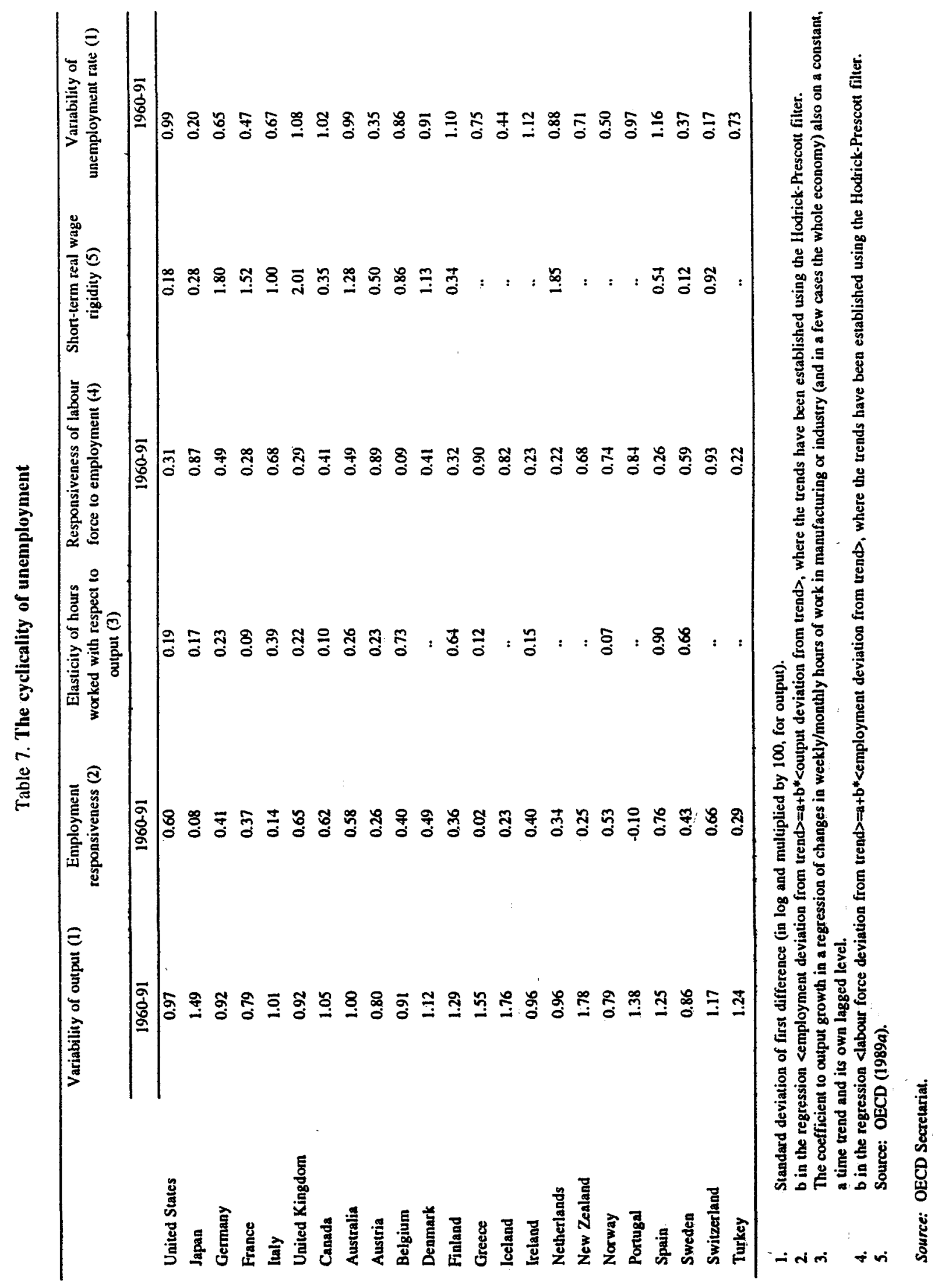


Table 8. Time-series properties of unemployment

\begin{tabular}{|c|c|c|c|c|c|}
\hline & \multicolumn{3}{|c|}{$\begin{array}{l}\text { Probability of unit root (1) against hypothesis of } \\
\text { stationarity with: }\end{array}$} & \multicolumn{2}{|c|}{$\begin{array}{l}\text { Persistence (2) } \\
\text { (standard deviation) }\end{array}$} \\
\hline & Constancy & Drift & Drift and trend & & \\
\hline United States & 0.59 & 0.08 & 0.09 & 0.35 & $(0.20)$ \\
\hline Japan & 0.87 & 0.80 & 0.69 & 0.91 & $(0.12)$ \\
\hline Germany & 0.54 & 0.55 & 0.11 & 0.95 & $(0.09)$ \\
\hline France & 0.99 & 0.95 & 0.51 & 1.04 & $(1.92)$ \\
\hline Italy & 0.98 & 0.91 & 0.30 & 1.03 & $(2.05)$ \\
\hline United Kingdom & 0.84 & 0.72 & 0.02 & 0.95 & $(0.10)$ \\
\hline Canada & 0.77 & 0.55 & 0.08 & 0.85 & $(0.19)$ \\
\hline Australia & 0.98 & 0.95 & 0.09 & 0.93 & $(0.12)$ \\
\hline Austria & 0.94 & 0.87 & 0.75 & 0.92 & $(0.12)$ \\
\hline Belgium & 0.62 & 0.56 & 0.54 & & \\
\hline Denmark & 0.99 & 0.91 & 0.37 & 0.97 & $(0.11)$ \\
\hline Finland & 0.98 & 0.89 & 0.01 & 0.45 & $(0.42)$ \\
\hline Greece & 0.79 & 0.63 & 0.62 & 0.96 & $(0.10)$ \\
\hline Iceland & 0.16 & 0.03 & 0.04 & 0.79 & $(0.17)$ \\
\hline Ireland & 0.97 & 0.91 & 0.33 & 1.03 & $(1.96)$ \\
\hline Netherlands & 0.74 & 0.74 & 0.15 & 0.96 & $(0.08)$ \\
\hline New Zealand & 1.00 & 1.00 & 1.00 & & \\
\hline Norway & 0.99 & 1.00 & $\quad 0.53$ & 0.94 & $(0.25)$ \\
\hline Portugal & $0.39^{\circ}$ & 0.23 & 0.36 & 0.67 & $(0.27)$ \\
\hline Spain & 0.89 & 0.86 & 0.01 & 0.96 & $\cdot(0.09)$ \\
\hline Sweden & 0.90 & 0.09 & 0.02 & 0.40 & $(0.25)$ \\
\hline Switzerland & 0.98 & 0.98 & 0.07 & 0.80 & $(0.20)$ \\
\hline Turkey & 0.97 & 0.68 & 0.20 & 0.91 & $(0.34)$ \\
\hline
\end{tabular}

1. Based on augmented Dickey-Fuller test. For the major seven countries, half-yearly data covering the period 1961S1 to 1991\$2 were used, while yearly data covering the same period were used for the small countries. The hypotheses being tested concern the noise process, $Z$, of the unemployment series, $U$, which also contains a deterministic trend, D. i.e. $U$ $=D+Z$. Three different specifications of the deterministic trend are considered, $D=c$ (first column), $D=c_{1}+$ $c_{2} \cdot$ TIME (second column), and $D=c_{1}+c_{2} \cdot T_{M E E}+c_{3} \cdot$ TIME $^{2}$ (third column) In all cases, the noise component is assumed to be an $A R(1)$ process and the test concerns the parameter a in $Z=a \cdot Z(-1)+e$, where $e$ is white noise. The null hypothesis of a unit root is represented by $a=1$ while stationarity implies that $a<1$. The table reports probabilities of accepting the null hypothesis. For additional information see Campbell and Perron (1991).

2. Coefficient on the AR(1) term in an estimated ARMA(1,x) process, where the length of the MA-process varies from country to country, depending on how many lags were significant at the 5 per cent level (in most cases the MA-process was of the first order). Yearly data were used for all countries. The estimation period was 1969-91. 
Table 9. Testing for the influence of employment on wage formation

(I) $\quad D \log W R=c+L^{*} A(M) * D \log W R+B(L)^{*} D \log P C P+C(L) * D \log P C D P B+d^{*} f(U N R)+g^{*}$ (UNR-UTREND)

(2) $\quad D \log (W R / P C P)=c+L^{*} A(M)^{*} D \operatorname{Dlog}(W R P C P)+B(M)^{*} D D \operatorname{Dog} P C P+C(L)^{*} D \operatorname{Dog}(P G D P B P C P)+d^{*} f(U N R)+g^{*}($ UNR-UTREND)

(3) $\quad D \log W R=c+L^{*} A(M)^{*} D \operatorname{Dlog} W R+B(L)^{*} D \operatorname{Dog} P C P+C(L) * D \log P G D P B+d^{*} f(U N R)+c^{*} D U N R$

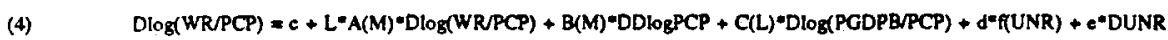

\begin{tabular}{|c|c|c|c|c|c|c|c|c|c|c|c|c|c|c|c|c|}
\hline \multirow{3}{*}{$\begin{array}{l}\text { Equation } \\
\text { Ass for ff ) } \\
\text { cocfticients }\end{array}$} & \multicolumn{2}{|c|}{ (1) } & \multicolumn{2}{|c|}{ (2) } & \multicolumn{2}{|c|}{ (3) } & \multicolumn{2}{|c|}{ (4) } & \multicolumn{2}{|c|}{ (1) } & \multicolumn{2}{|c|}{ (2) } & \multicolumn{2}{|c|}{ (3) } & \multicolumn{2}{|c|}{ (4) } \\
\hline & \multicolumn{2}{|c|}{ Level } & \multicolumn{2}{|c|}{ Leveil } & \multicolumn{2}{|c|}{ Leve! } & \multicolumn{2}{|c|}{ Level } & \multicolumn{2}{|c|}{ Logs $/ 100$} & \multicolumn{2}{|c|}{ Logg/100 } & \multicolumn{2}{|c|}{$\log s / 100$} & \multicolumn{2}{|c|}{$\log x 1100$} \\
\hline & d & $\mathbf{B}$ & d & 8 & d & e & d & e & d & s & d & B & d & e & $d$ & e \\
\hline \multicolumn{17}{|c|}{ Panel A. Using half-yearly dats } \\
\hline Uniled Stales & -011 & 012 & $-024=*$ & $024^{*}$ & .005 & .031 ** & $-010^{*}$ & $-040^{-4}$ & .069 & 012 & $-134=$ & $022=$ & .038 & $-032=$ & $.066^{*}$ & $.041=$ \\
\hline Japan & $-2.65 * *$ & 094 & $.199 * *$ & 085 & $-2.37=$ & 056 & $-1.68=4$ & -103 & $.554^{* *}$ & 061 & $-443 * *$ & 068 & $-527 * \bullet$ & 039 & $-404 *$ & -112 \\
\hline Germany & $-042^{-*}$ & .002 & $-037 * \cdots$ & 015 & $-041=$ & $-116^{40}$ & $-038=\ldots$ & $-143=*$ & $.069=$ & .024 & $-067 *$ & .009 & $-066=$ & $-125 * *$ & $.060^{* *}$ & $-126==$ \\
\hline France & $-025 * *$ & -010 & $.018 \cdots$ & $.020=$ & $.026^{* *}$ & .060 & $-0.23=*$ & $-079=$ & $.120^{* 0}$ & -017 & $-110=0$ & $.021 *$ & $-133=*$ & $.064=$ & $-129 *$ & $.070^{* \cdots}$ \\
\hline Italy & $.042=$ & .040 & $-038=0$ & 034 & $.044=$ & .082 & $-037^{\infty-\infty}$ & .103 & $-353 * *$ & -036 & $-343=$ & 033 & $-360^{-1}$ & .076 & $-3.37==$ & .098 \\
\hline $\begin{array}{l}\text { United } \\
\text { Kingdom }\end{array}$ & 000 & -004 & .004 & 013 & -001 & .014 & .001 & $-051^{\circ}$ & .004 & .003 & -027 & 012 & .007 & .014 & $-0: 14$ & $.050^{\circ}$ \\
\hline Canada & .005 & .015 & .008 & .017 & .011 & .004 & -013 & .028 & .028 & .017 & -047 & .019 & .065 & -005 & .085 & -029 \\
\hline \multicolumn{17}{|c|}{ Panel B. Using yearly dent } \\
\hline United Swles & -007 & .019 & $-032^{*}$ & -005 & .020 & $.033^{*}$ & $-030^{=*}$ & $.042^{*+\infty}$ & .063 & -018 & $-184^{*}$ & .009 & -134 & $-035=$ & $-188=$ & $.0+4=$ \\
\hline Japan & $.270=0$ & 104 & $-199 *$ & 109 & $-2.25 * *$, & .061 & -147 & -241 & $-563=0$ & 059 & $-463^{10=}$ & 087 & $.512=$ & .073 & $-390^{=*}$ & .2 .37 \\
\hline Germany & $.083^{* *}$ & 013 & $.084 * *$ & 036 & $-076^{* *}$ & .0 .75 & $-0.73^{-*}$ & $.096=$ & $-158=$ & -037 & $.163^{=-*}$ & .022 & $-148^{* *}$ & $.095=$ & $-147==$ & $.088^{*}$ \\
\hline France & $-068 *$ & .017 & .05100 & .045 & $-071^{*=}$ & -0.36 & $-061=$ & -077 & $-352=0$ & .042 & $-311=0$ & $-056^{\circ}$ & $.377=0$ & .049 & $-349=*$ & -076 \\
\hline Itaty & $-079=$ & -006 & $.070^{* * *}$ & 060 & .08500 & .080 & $-079=0$ & $-10 t$ & $-665 * *$ & .006 & $-636^{m-}$ & 051 & $.714^{* *}$ & -082 & $-715 *$ & -106 \\
\hline $\begin{array}{l}\text { United } \\
\text { Kingdom }\end{array}$ & -001 & 004 & -007 & 044 & .000 & 006 & 001 & -0.47 & .008 & 004 & .0 .47 & 042 & .005 & 007 & .016 & .046 \\
\hline Canada & .015 & -000 & .026 & 003 & .014 & 015 & .025 & -025 & -109 & .003 & -187 & .002 & -105 & 014 & -187 & .026 \\
\hline Australia & .041 & .120 & .041 & .120 & $-085^{\circ}$ & 0.80 & $-081=$ & 080 & -1.76 & -136 & -186 & -135 & .362 & 063 & $-368=$ & 062 \\
\hline Austria & .024 & -155 & -0.15 & $-166^{\circ}$ & .022 & $-2.21=$ & .029 & -2.1000 & -1.91 & .108 & -103 & $-151 *$ & -141 & -180 & -107 & $-201=0$ \\
\hline Belgium & $-117^{* 0}$ & 008 & $-10 I^{*}$ & .014 & $+1.15 * *$ & -051 & $-109 * *$ & .084 & $.539= \pm$ & -073 & $-497^{* * *}$ & .079 & $-657^{=0}$ & .0 .56 & $.633^{* *}$ & .080 \\
\hline Deumark & $.026=$ & $.067=$ & $.028=*$ & $.064 * 0$ & .04600 & 039 & $-038=\ldots$ & 0.16 & $-096=$ & $.075^{* *}$ & $-108=$ & $.070=$ & $.159^{\circ=}$ & 024 & $-144=$ & 013 \\
\hline Netherlands & .070 & -007 & .011 & .063 & -0.54 & .074 & -0.41 & .097 & -2.64 & -045 & -086 & -059 & .253 & .075 & -1.93 & .097 \\
\hline New Zealand & .007 & .092 & -005 & .070 & -005 & .0 .24 & -002 & .037 & -047 & .088 & -063 & -072 & -052 & 005 & .065 & 012 \\
\hline Norway & -0.62 & 070 & .041 & 0.47 & -028 & -099 & -0.12 & -129 & -172 & 064 & -152 & $0 \leq 53$ & -0.92 & -094 & .071 & -119 \\
\hline Pontugal & -147 & .035 & $-122 * *$ & .0 .54 & $-176^{* 0}$ & -0.25 & $-1400=$ & -0.11 & .720 & .021 & $.587 \times 0$ & .045 & $-787^{* 0}$ & -023 & $.655 * 0$ & .007 \\
\hline Spain & $-045=0$ & $056^{\circ *}$ & $-0.44=0$ & $058=$ & .020 & 033 & -013 & -018 & $0.92^{*}$ & .030 & 047 & -007 & $096=$ & $-155=$ & $095=$ & $-146^{\circ}=$ \\
\hline Sweden & 157 & -400 & -178 & 004 & .063 & $-368^{\circ=}$ & -0.66 & $-4.46^{m *}$ & 088 & -290 & .349 & 0.08 & -145 & $-363=0$ & .143 & $-443^{* *}$ \\
\hline Switzer land & $.421^{\ldots \bullet}$ & 3.56 & $-421==$ & 356 & $-387^{* *}$ & 14 & $-356 *$ & 079 & $.081^{* \ldots}$ & 060 & $-0.73=0$ & 092 & $.083=$ & 061 & $-071=$ & .068 \\
\hline Turkey & 033 & .195 & 034 & .196 & .113 & -257 & -068 & -1.43 & 1205 & -343 & 7.98 & -277 & -902 & -2.33 & 473 & -129 \\
\hline
\end{tabular}

Note: The variables are as follows: WR: wage rate per employec in the business sector, PCP: private consumption defrator, PGDPB: value-added deflator in the business sector, UNR:

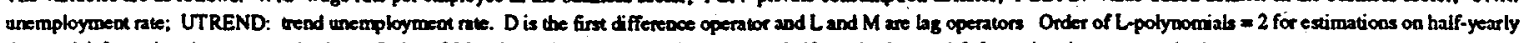
data and 1 for extimations on yearty dera; Order of M-polynomials = 1 for extimations on balf-yearty dala and 0 for estimations on yearty data.

Asterisks represed significanse: $\cdots=5$ per cent; $"=10$ per cent 
Table 10. Impact of job change on unemployment (1)

\begin{tabular}{|c|c|c|c|c|c|c|c|}
\hline \multirow{2}{*}{ Country } & \multirow{2}{*}{ Constant } & \multicolumn{2}{|c|}{$\begin{array}{l}\text { Coefficient on cyclically-adjusted } \\
\text { employment shake-out }\end{array}$} & \multirow{2}{*}{$\begin{array}{l}\text { Coefficient of lagged } \\
\text { unemployment }\end{array}$} & \multirow{2}{*}{ DW } & \multirow{2}{*}{$\mathrm{R}^{2}$} & \multirow{2}{*}{$\begin{array}{l}\text { Estimation } \\
\text { period }\end{array}$} \\
\hline & & Actual & $\begin{array}{l}\text { One-period } \\
\text { lagged }\end{array}$ & & & & \\
\hline \multicolumn{8}{|c|}{ Panel A. Impact of sectoral employment shake-out } \\
\hline United States & 0.39 & $1.24^{* * *}$ & $0.39 * * *$ & .0 .066 & 1.74 & 0.48 & $1962-88$ \\
\hline Japan & 0.44 & 0.08 & -0.16 & -0.169 & 1.71 & 0.21 & $1972-88$ \\
\hline Germany & 1.12 & $0.49 * * *$ & $0.34 * *$ & -0.212 & (2) & 0.53 & $1963-88$ \\
\hline France & 0.38 & $1.09^{*}$ & 0.84 & 0.007 & 1.99 & 0.36 & $1973-88$ \\
\hline Italy & 0.21 & 0.10 & 0.04 & 0.023 & 1.95 & 0.02 & 1972.88 \\
\hline United Kingdom & 0.89 & $0.57^{* * *}$ & 0.13 & -0.127 & (2) & 0.38 & $1965-88$ \\
\hline Canada & 3.40 & $0.74^{*}$ & -0.13 & -0.373 & (2) & 0.54 & $1972-87$ \\
\hline Australia & 0.61 & 1.25 & 0.14 & .0 .053 & 2.48 & 0.39 & $1972-88$ \\
\hline Belgium & 0.73 & $0.96^{* * *}$ & $0.70^{* * *}$ & -0.030 & 1.95 & 0.83 & $1973-88$ \\
\hline Denmark & 0.83 & $1.10^{* * *}$ & -0.20 & .0 .052 & (2) & 0.66 & $1969-88$ \\
\hline Finland & 2.76 & -0.78 & 0.18 & -0.578 & (2) & 0.36 & $1979-89$ \\
\hline Netherlands & 0.39 & $1.35 * * *$ & 0.21 & 0.024 & 1.50 & 0.84 & $1973-88$ \\
\hline Sweden & 0.86 & 0.28 & 0.14 & $-0.442^{*}$ & (2) & 0.32 & $1972-88$ \\
\hline Norway & 0.15 & $0.75^{* * *}$ & $-0.42^{*}$ & -0.067 & 1.52 & 0.44 & $1965-87$ \\
\hline \multicolumn{8}{|c|}{ Panel B. Impact of regional employment shake-out } \\
\hline United States & 0.74 & $0.78^{* *}$ & 0.15 & -0.122 & 1.69 & 0.27 & $1962-87$ \\
\hline Japan & 0.46 & 0.33 & 0.75 & -0.163 & 2.55 & 0.29 & $1976-87$ \\
\hline Germany & 0.11 & $0.55^{* * *}$ & 0.09 & 0.068 & (2) & 0.44 & $1963-85$ \\
\hline France & 0.48 & $1.25 * *$ & 0.63 & 0.010 & 2.64 & 0.55 & $1976-87$ \\
\hline Italy & -0.32 & 0.14 & 0.05 & 0.090 & 2.01 & 0.09 & $1963-87$ \\
\hline United Kingdom & 1.02 & $0.51^{* *}$ & 0.13 & -0.153 & (2) & 0.27 & $1967-89$ \\
\hline Canada & 2.78 & 0.62 & 0.12 & -0.324 & (2) & 0.37 & $1969-87$ \\
\hline Australia & 0.74 & $1.28^{* *}$ & -0.15 & .0 .091 & 2.21 & 0.33 & $1968-87$ \\
\hline Austria & 0.31 & 0.51 & 0.05 & -0.061 & 1.95 & 0.26 & $1973-87$ \\
\hline Finland & 4.20 & -0.15 & 0.52 & -0.809 & 2.42 & 0.81 & $1979-87$ \\
\hline Norway & 1.29 & $1.02^{*}$ & -0.23 & .0 .496 & (2) & 0.52 & 1977.88 \\
\hline Spain & 8.63 & 0.27 & -0.14 & -0.409 & (2) & 0.67 & 1979-88 \\
\hline Sweden & 0.13 & 0.75 & -0.10 & -0.186 & (2) & 0.39 & $1978-87$ \\
\hline
\end{tabular}

1. Based on estimates of the following equation: DUR $=a+b^{*} E S+c^{*} E S(-1)+d^{*} U R(-1)$; where DUR is change in unemployment rate, $E S$ is cyclically-adjusted employment shake-out (see Figure 10 ) and UR is the unemployment rate. The asterisk indicates significance levels: *** = significant at the 1 per cent level.

** $=$ significant at the 5 per cent level.

* = significant at the 10 per cent level.

2. Has been estimated using the Cochrane-Orcutt method to deal with first-order autocorrelation.

Source: OECD Secretariat. 
Table 11. Decomposition of employment growth

\begin{tabular}{|c|c|c|c|c|c|c|c|}
\hline \multirow[b]{3}{*}{ Total private sector } & \multirow[b]{2}{*}{ Period } & \multicolumn{3}{|c|}{ Contribution to change in output growth } & \multirow[b]{2}{*}{$\begin{array}{l}\text { Output } \\
\text { growth (1) }\end{array}$} & \multirow[b]{2}{*}{$\begin{array}{c}\text { Productivity (2) } \\
\text { effect }\end{array}$} & \multirow[b]{2}{*}{$\begin{array}{l}\text { Employment } \\
\text { growth }\end{array}$} \\
\hline & & $\begin{array}{l}\text { Domestic } \\
\text { demand }\end{array}$ & Export & Import & & & \\
\hline & & & & & & & \\
\hline United States & $1972-85$ & 2.68 & 0.34 & -0.29 & 2.84 & -0.86 & 1.99 \\
\hline Japan & $1970-85$ & 3.92 & 0.87 & -0.12 & 4.48 & -3.68 & 0.80 \\
\hline Germany & $1978-86$ & 1.12 & 0.90 & -0.45 & 1.62 & -1.42 & 0.19 \\
\hline France & 1977.85 & 1.54 & 0.64 & -0.37 & 1.93 & -2.12 & 0.02 \\
\hline United Kingdom & $1968-84$ & 2.15 & 0.69 & -0.63 & 2.47 & -2.44 & 0.02 \\
\hline Canada & $1974-86$ & 2.07 & 1.11 & -0.18 & 3.00 & -1.91 & 1.08 \\
\hline Australia & $1974-86$ & 3.04 & 0.45 & -0.31 & 2.84 & -1.31 & 1.52 \\
\hline \multicolumn{8}{|l|}{ Manufacturing } \\
\hline United States & $1972-85$ & 2.97 & 0.80 & -0.97 & 2.47 & -2.32 & 0.15 \\
\hline Japan & $1970-85$ & 3.60 & 2.40 & -0.05 & 6.15 & -5.96 & 0.18 \\
\hline Germany & $1978-86$ & 0.57 & 1.77 & -1.07 & 0.94 & -1.88 & -0.93 \\
\hline France & $1977-85$ & 0.68 & 1.22 & -1.17 & 0.66 & -2.80 & -2.14 \\
\hline United Kingdom & $1968-84$ & 1.01 & 1.03 & -1.72 & 0.24 & -2.48 & -2.24 \\
\hline Canada & $1981-86$ & 0.69 & 2.55 & -0.95 & 2.19 & -2.80 & -0.61 \\
\hline Australia & $1974-86$ & 2.36 & 0.55 & -1.08 & 1.39 & -2.96 & -1.56 \\
\hline Low-tech manufacturing & & & ; & & & & \\
\hline United States & $1972-85$ & 1.90 & 0.32 & -0.79 & 0.63 & -1.29 & -0.66 \\
\hline Japan & $1970-85$ & 2.20 & 0.57 & -0.20 & 2.24 & -2.85 & -0.61 \\
\hline Germany & $1978-86$ & 0.28 & 1.03 & -1.09 & -0.69 & -1.51 & -2.18 \\
\hline France & $1977-85$ & 0.55 & 0.80 & -1.11 & 0.04 & -2.41 & -2.45 \\
\hline United Kingdom & $1968-84$ & 0.72 & 0.35 & -1.11 & -0.46 & -2.08 & -2.53 \\
\hline Canada & $1981-86$ & 0.74 & 1.40 & -0.65 & 1.18 & -2.09 & -0.91 \\
\hline Australia & $1974-86$ & 2.40 & 0.48 & -0.55 & 1.73 & -3.14 & -1.41 \\
\hline
\end{tabular}

1. The previous three columns do not add up to total output growth because of changes in input-output coefficients.

2. Mechanical effect of productivity increase on employment growth, output growth held unchanged.

Source: $\quad$ OECD (1992b). 


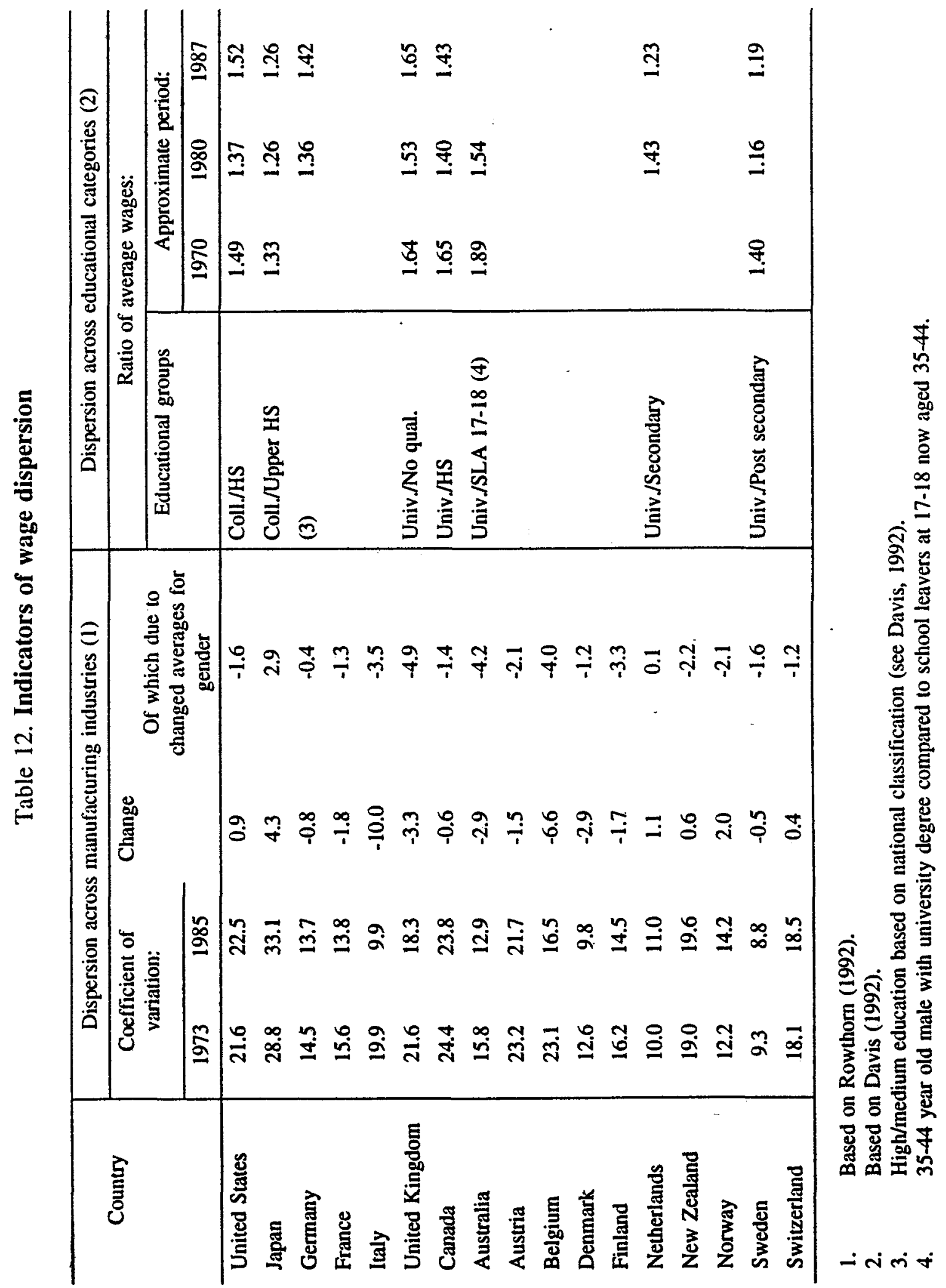




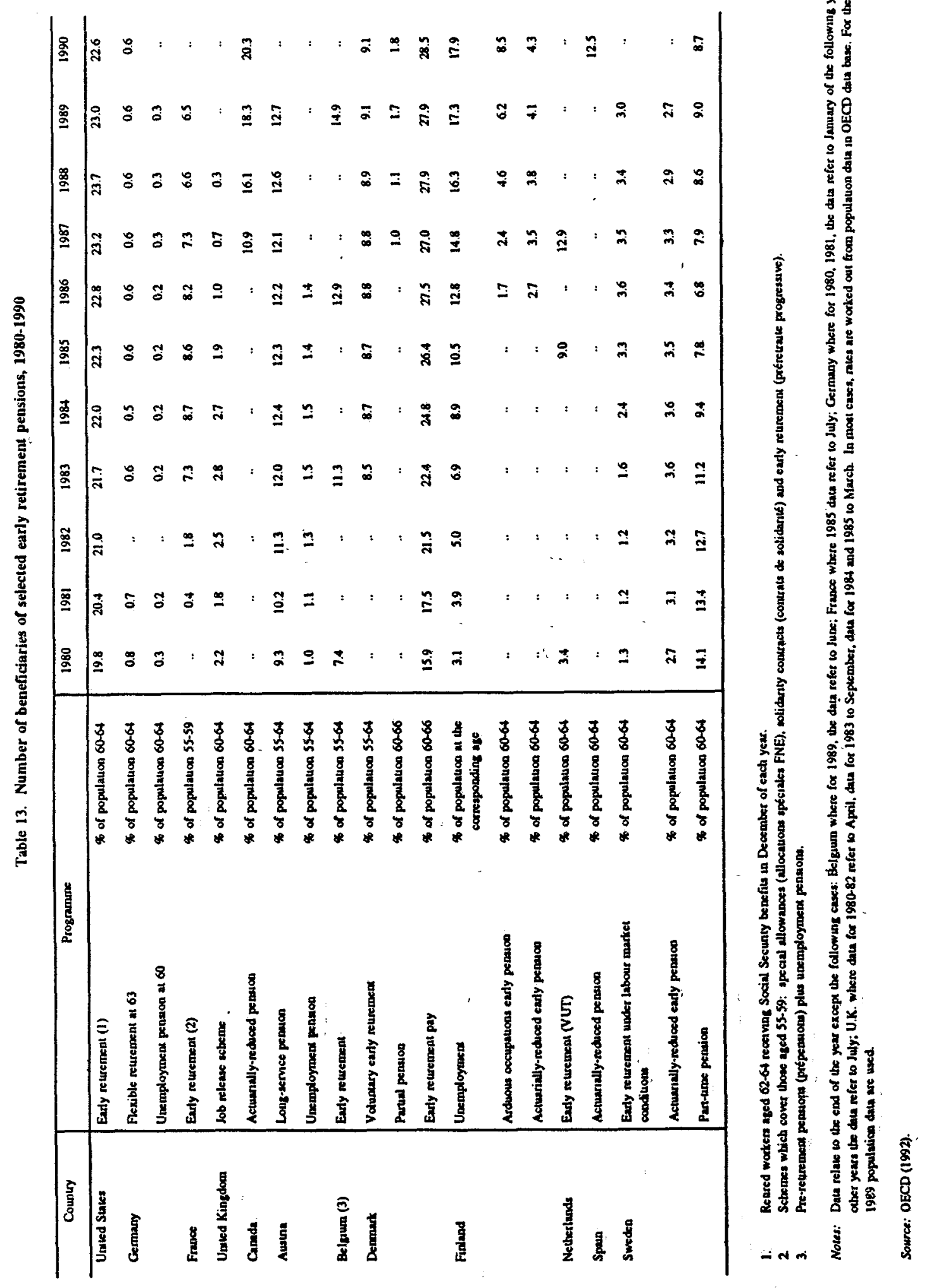




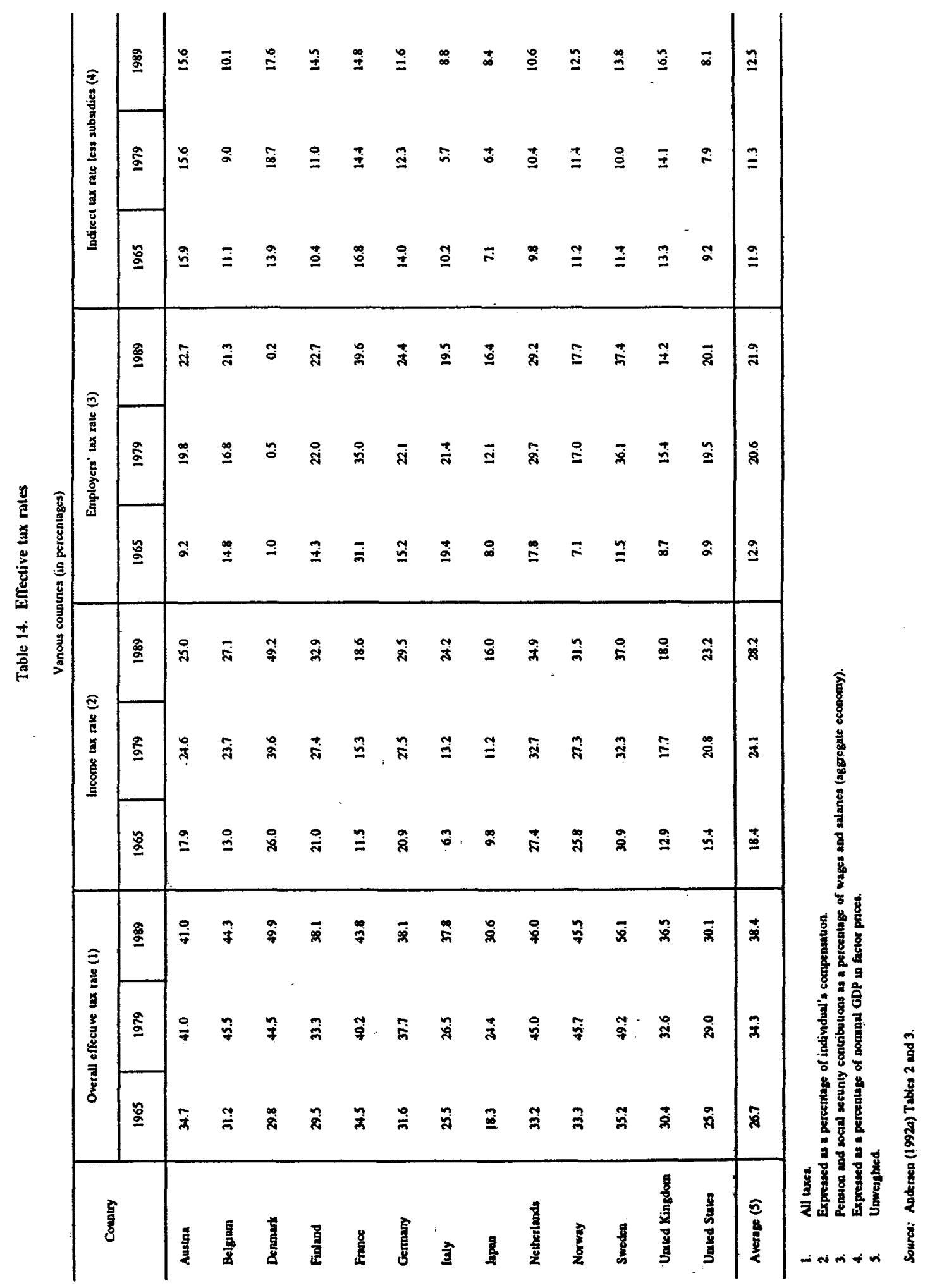


Table 15. Labour market policies

\begin{tabular}{|c|c|c|c|}
\hline & $\begin{array}{l}\text { Public expenditures on labour } \\
\text { market policies as a share of GDP } \\
\text { (1) }\end{array}$ & $\begin{array}{l}\text { Share of expenditure on "active" } \\
\text { measures in total expenditures (1) }\end{array}$ & $\begin{array}{c}\text { 6-year change in active } \\
\text { expenditure as a share of GDP } \\
\text { (2) }\end{array}$ \\
\hline United States & 0.84 & 29.8 & -0.03 \\
\hline Japan & 0.44 & 29.5 & -0.03 \\
\hline Germany & 2.73 & 44.3 & 0.40 \\
\hline France & 2.68 & 29.9 & 0.13 \\
\hline Italy & 1.52 & 52.6 & 0.35 \\
\hline United Kingdom & 1.91 & 29.3 & -0.18 \\
\hline Canada & 2.87 & 21.6 & -0.01 \\
\hline Australia & 1.39 & 19.4 & -0.15 \\
\hline Austria & 1.44 & 24.3 & 0.07 \\
\hline Belgium & 3.78 & 28.3 & -0.16 \\
\hline Denmark & 6.12 & 22.7 & 0.30 \\
\hline Finland & 3.44 & 38.1 & 0.40 \\
\hline Greece & 1.22 & 40.2 & 0.28 \\
\hline Ireland & 4.31 & 34.3 & -0.10 \\
\hline Netherlands & 3.28 & 32.6 & -0.02 \\
\hline New Zealand & 2.73 & -30.4 & -0.01 \\
\hline Norway. & 2.26 & 45.1 & 0.36 \\
\hline Portugal & 0.80 & 62.5 & 0.09 \\
\hline Spain & 3.53 & 21.5 & 0.42 \\
\hline Sweden & 3.75 & 55.2 & -0.04 \\
\hline Switzerland & 0.61 & 39.3 & 0.04 \\
\hline Turkey & 0.16 & 100.0 & 0.01 \\
\hline Er & 2.54 & 37.3 & 0.20 \\
\hline Total OECD & 1.49 & 32.8 & 0.05 \\
\hline
\end{tabular}

1. For the latest year available, 1991, except 1988 for Italy, 1989 for Turkey and 1990 for France. Belgium and the Netherlands. Data for the United States, Japan. the United Kingdom, Canada, Australia. New Zealand and Sweden are on a fiscal-year basis.

2. The changes are between the latest year available and 1985 except 1986 for Denmark. Portugal and Turkey; and fiscal years $1991-92$ and 1985-86 for the United States, the United Kingdom, Canada and Sweden; 1990-91 and 1987-88 for Japan; 1990-91 and 1985-86 for Australia and New Zealand.

Source:

OECD, Employment Outlook, July 1992. 
Figure 1. Unemployment and participation rates

Unemployment rate, left scale

Participation rate, right scale (1)

OECD

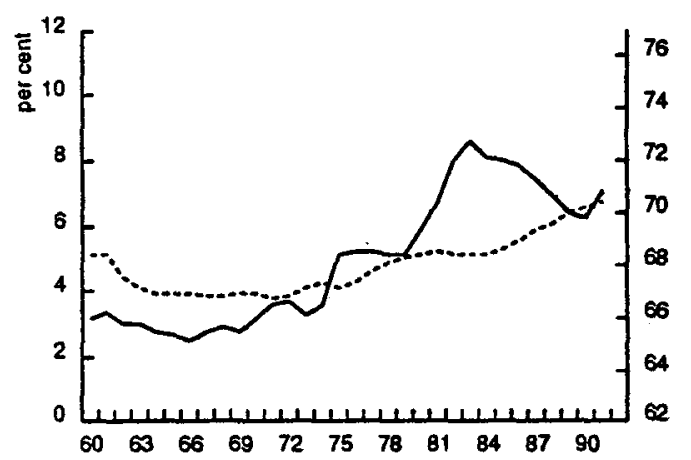

Japan

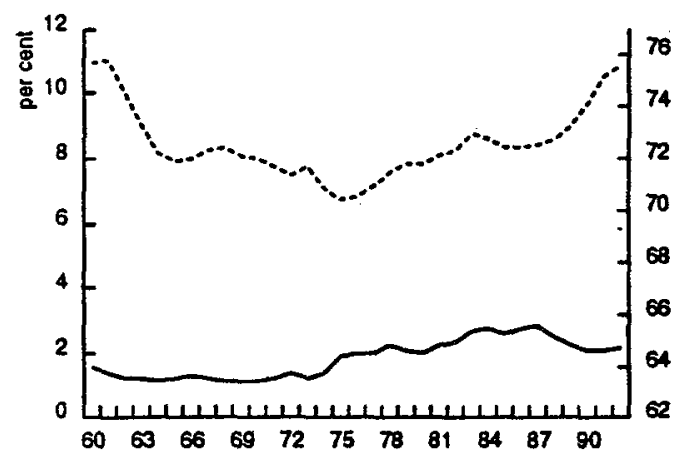

EFTA

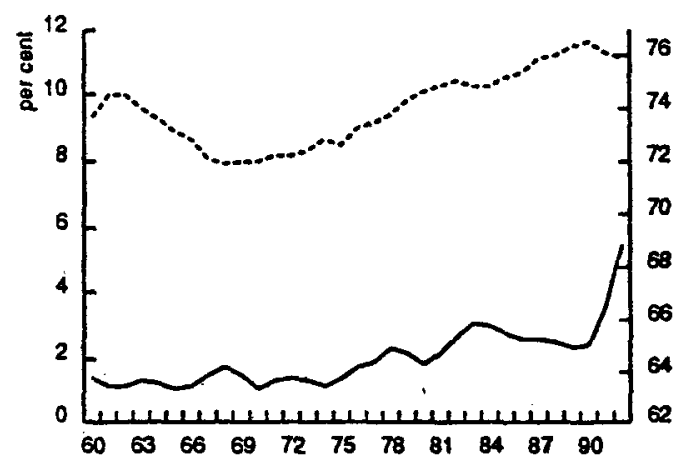

1. Labour force as a shave of the population aged $15-64$ yeare
United States

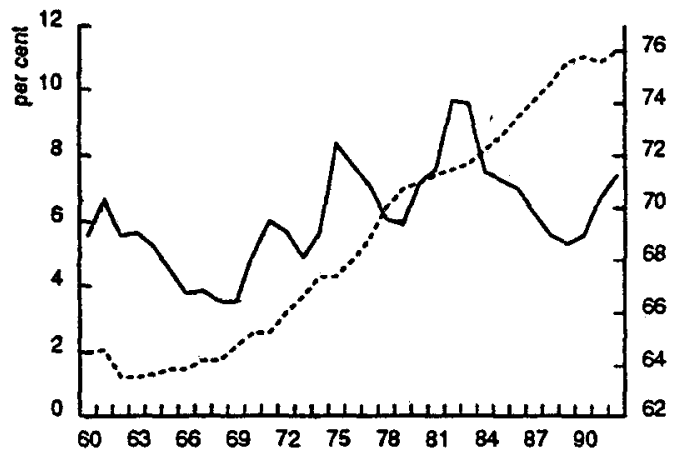

EC

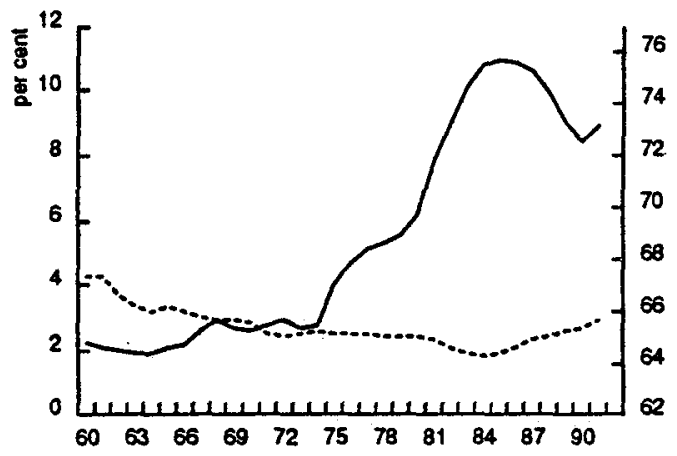

Canada, Australia

and New Zealand

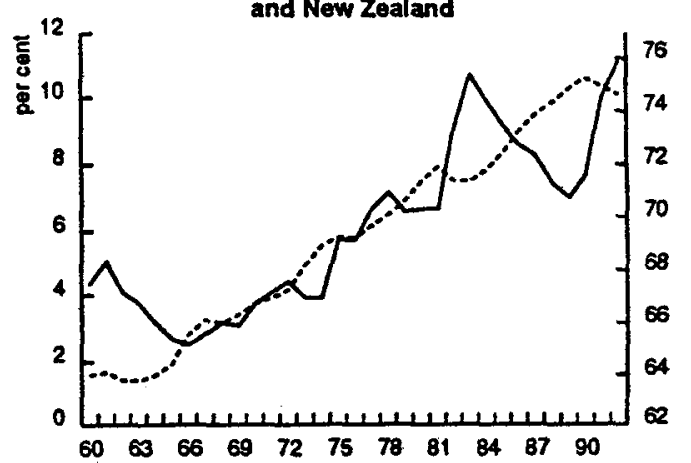


Figure 2. Indicators of the trend OECD unemployment rate (1)

A. NAWRU-Indicator (2)

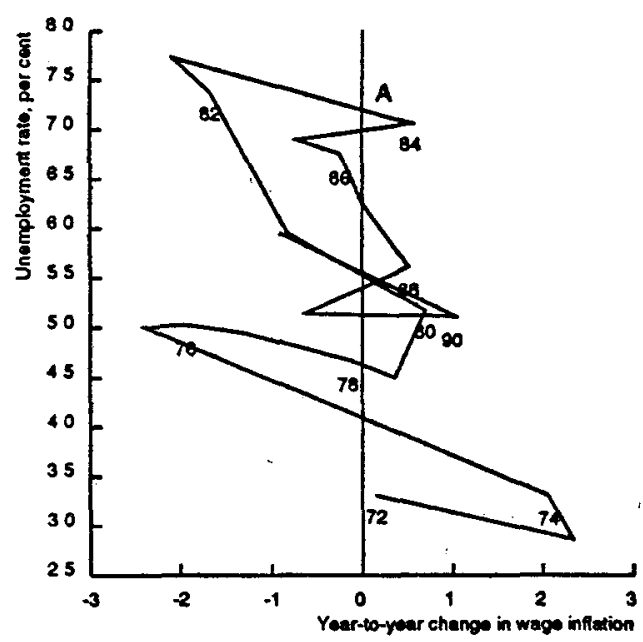

C. Okun curve

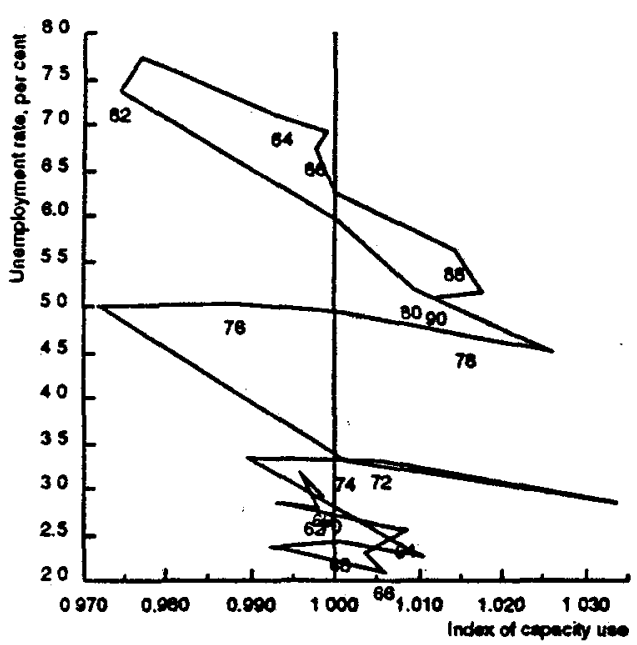

B. Beveridge curve (3)

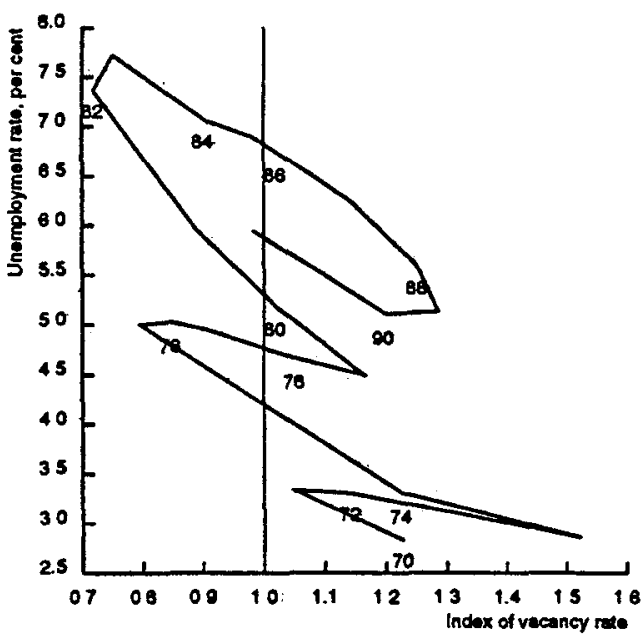

D. Unemployment and trends (4)

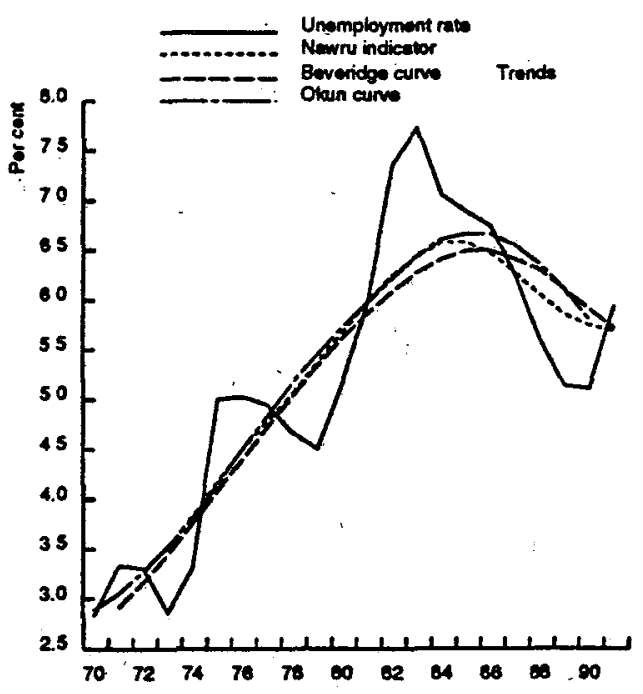

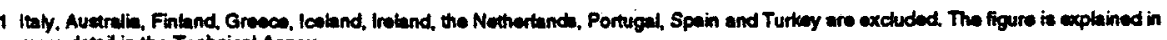
more detail in the Technical Annex.

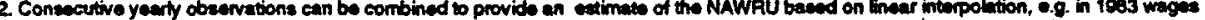

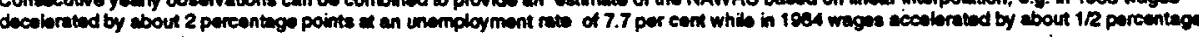
point at an unemploymont rute of 7.t, suggeating a NAWRUS of bout 7.2 per cont es indicated by point A.

The index of vecancy rate is calculated by woighting wogether, with bour force woightw, individual country indicas baend on the

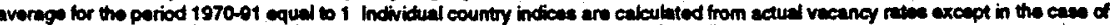

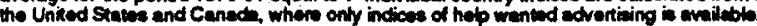

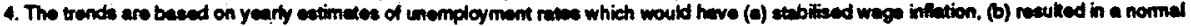

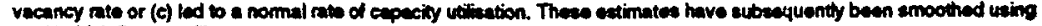

the Hodicki-P macott filker. 

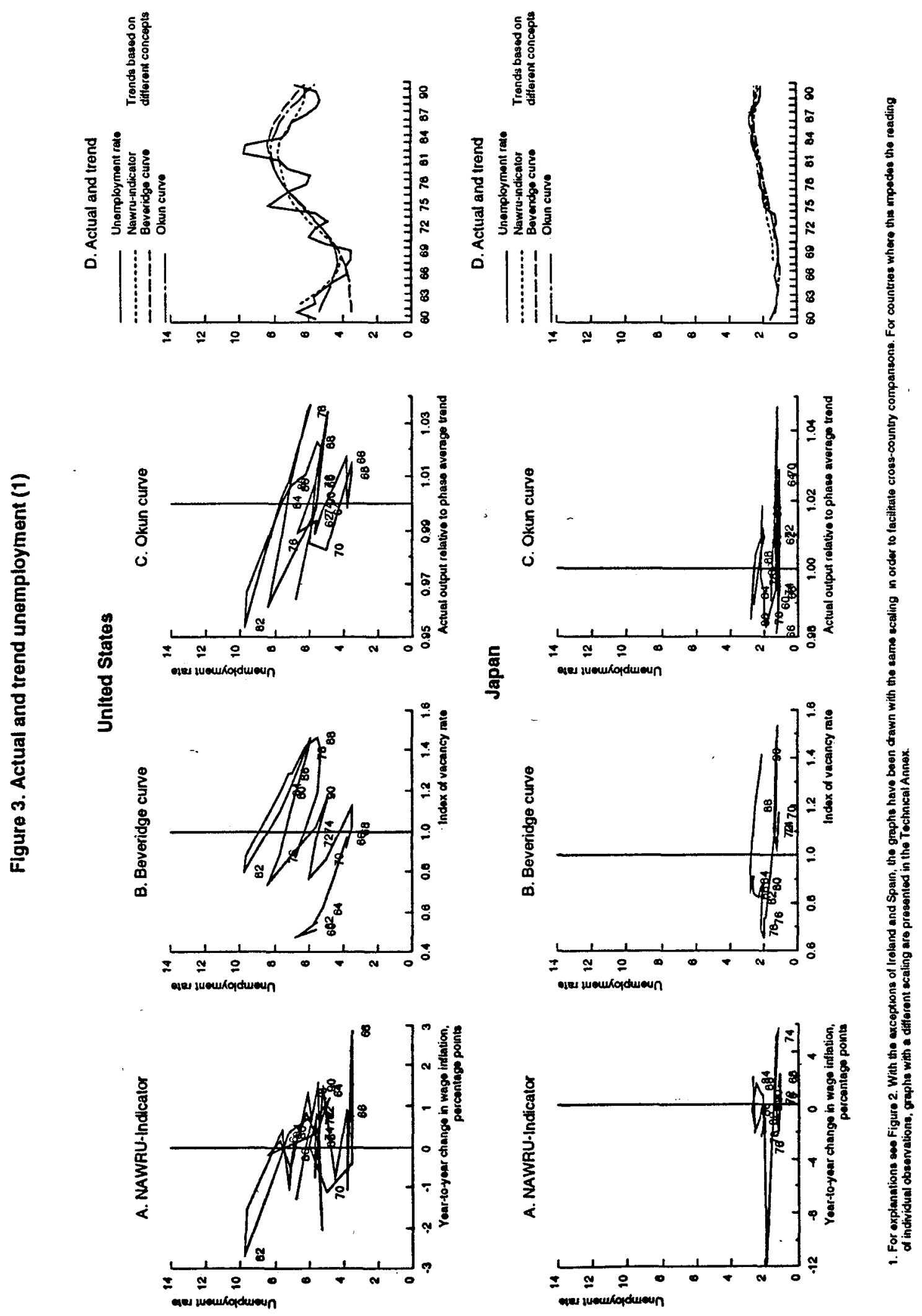


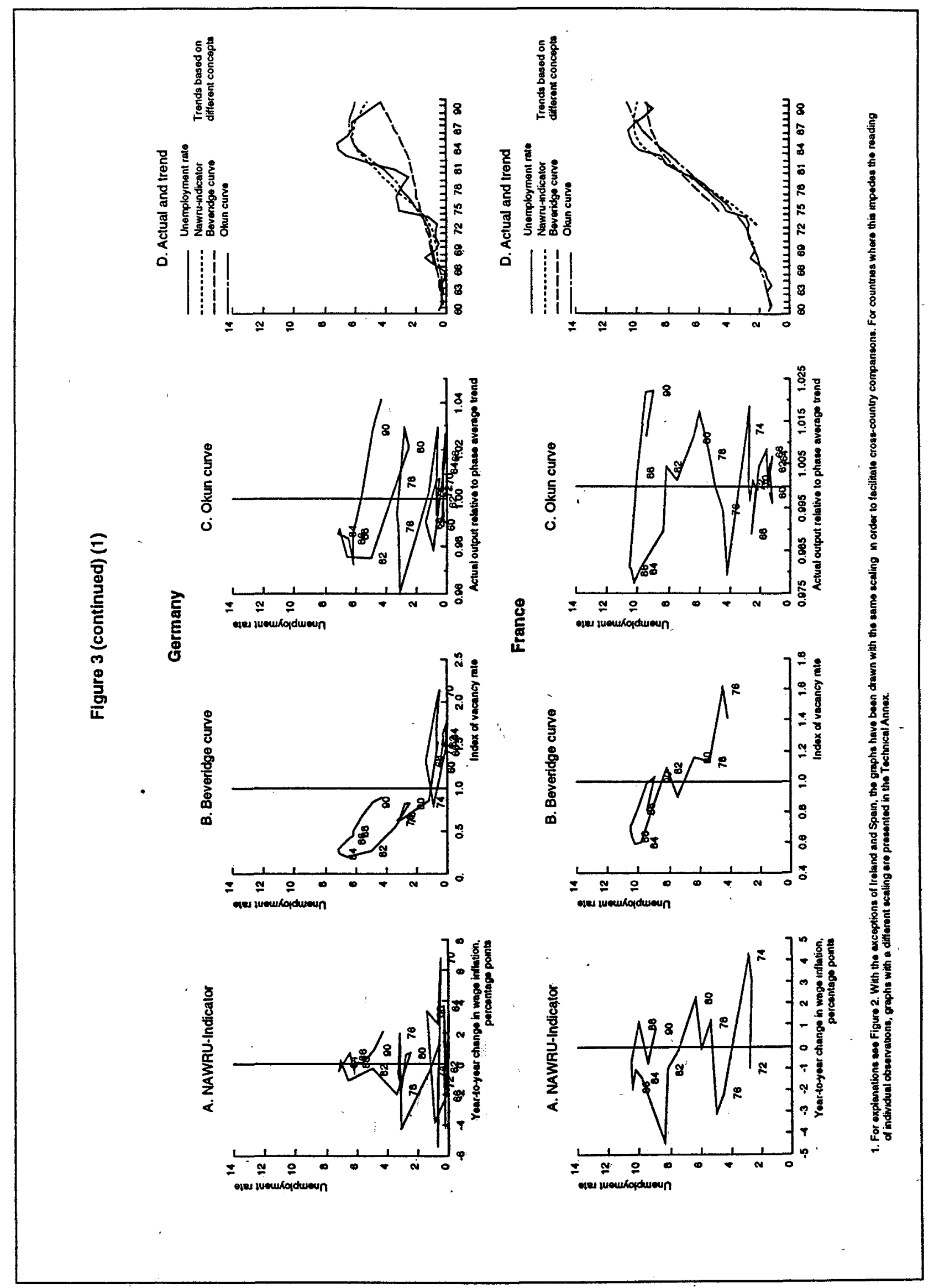




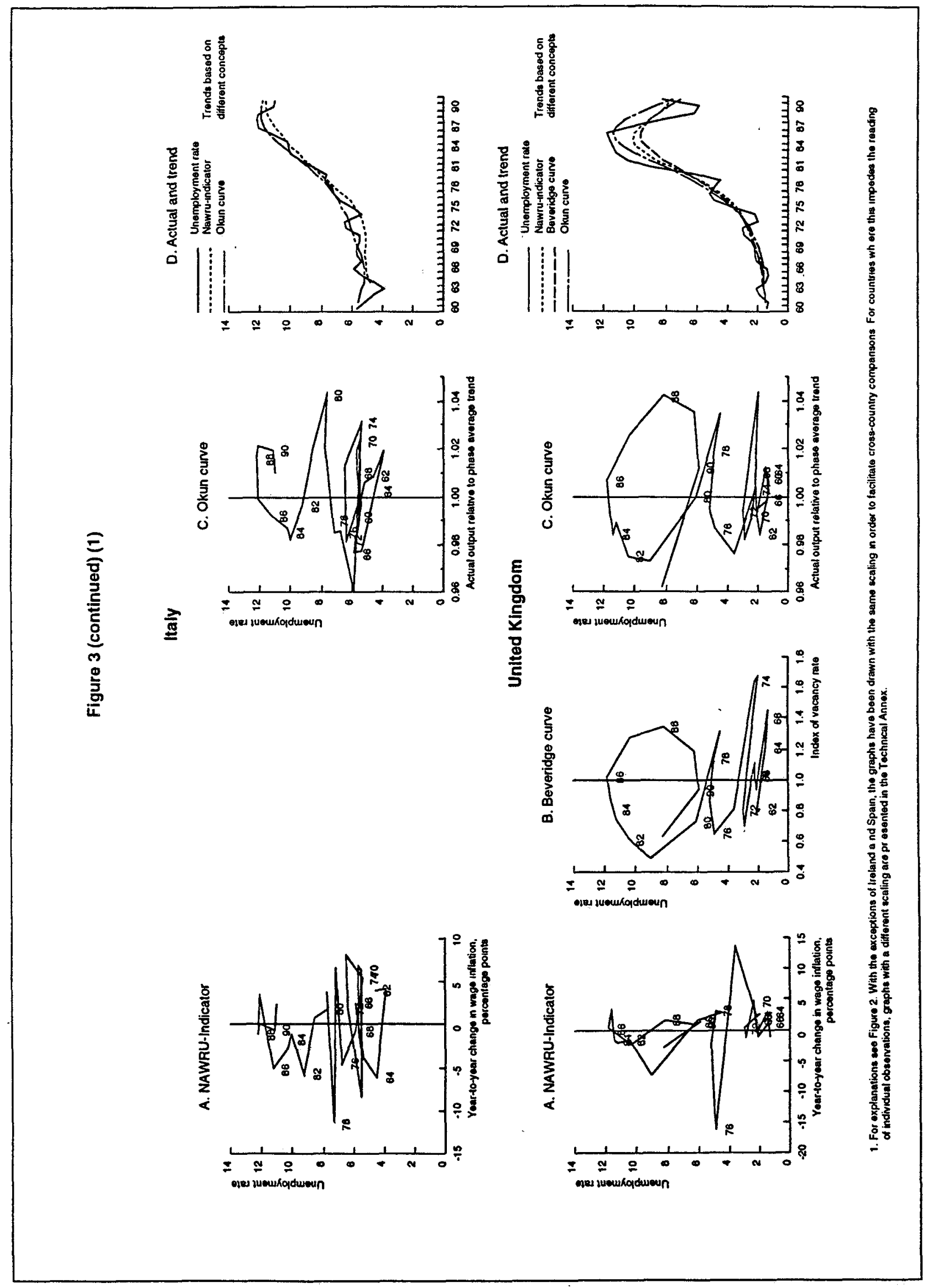




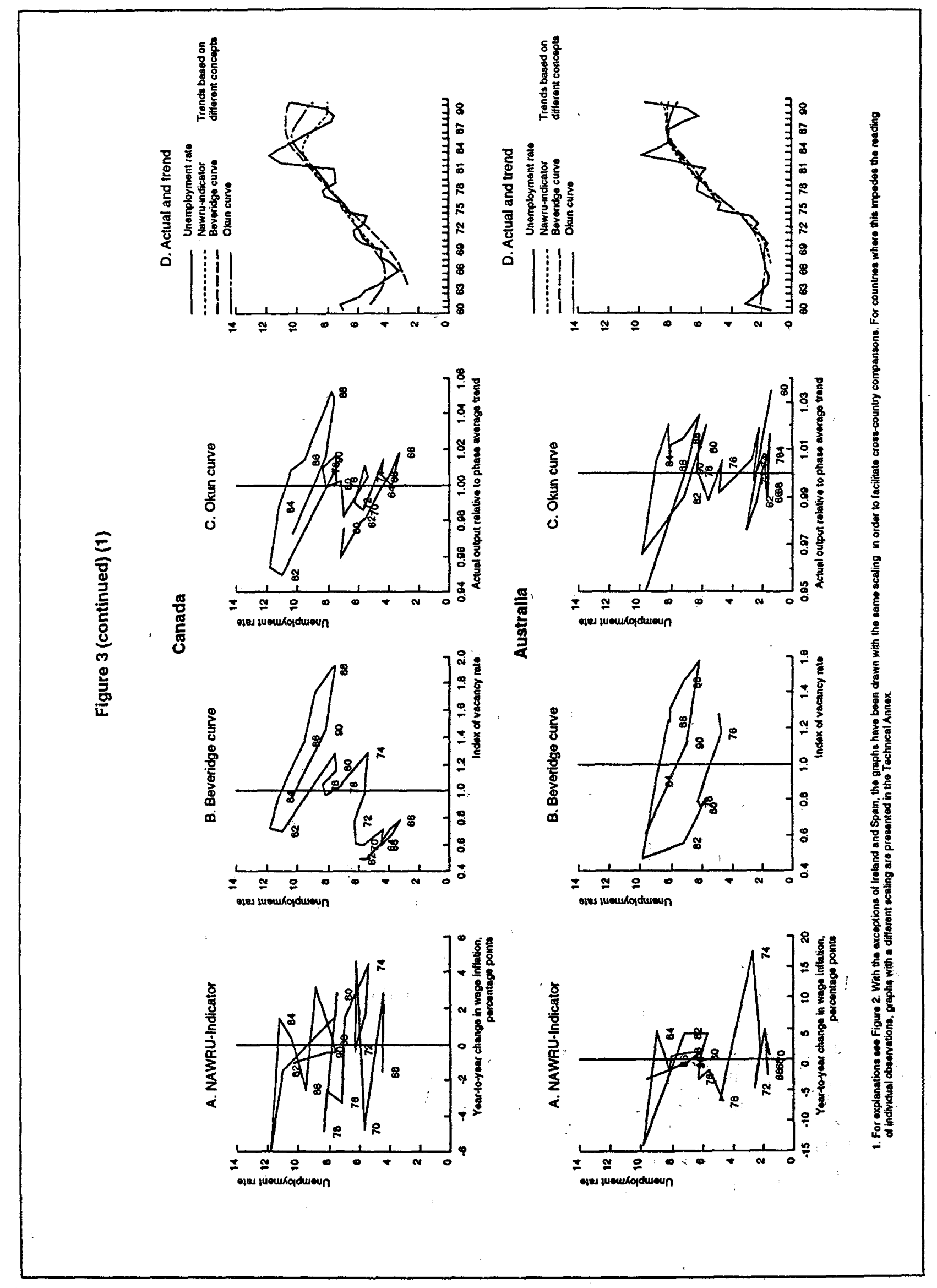




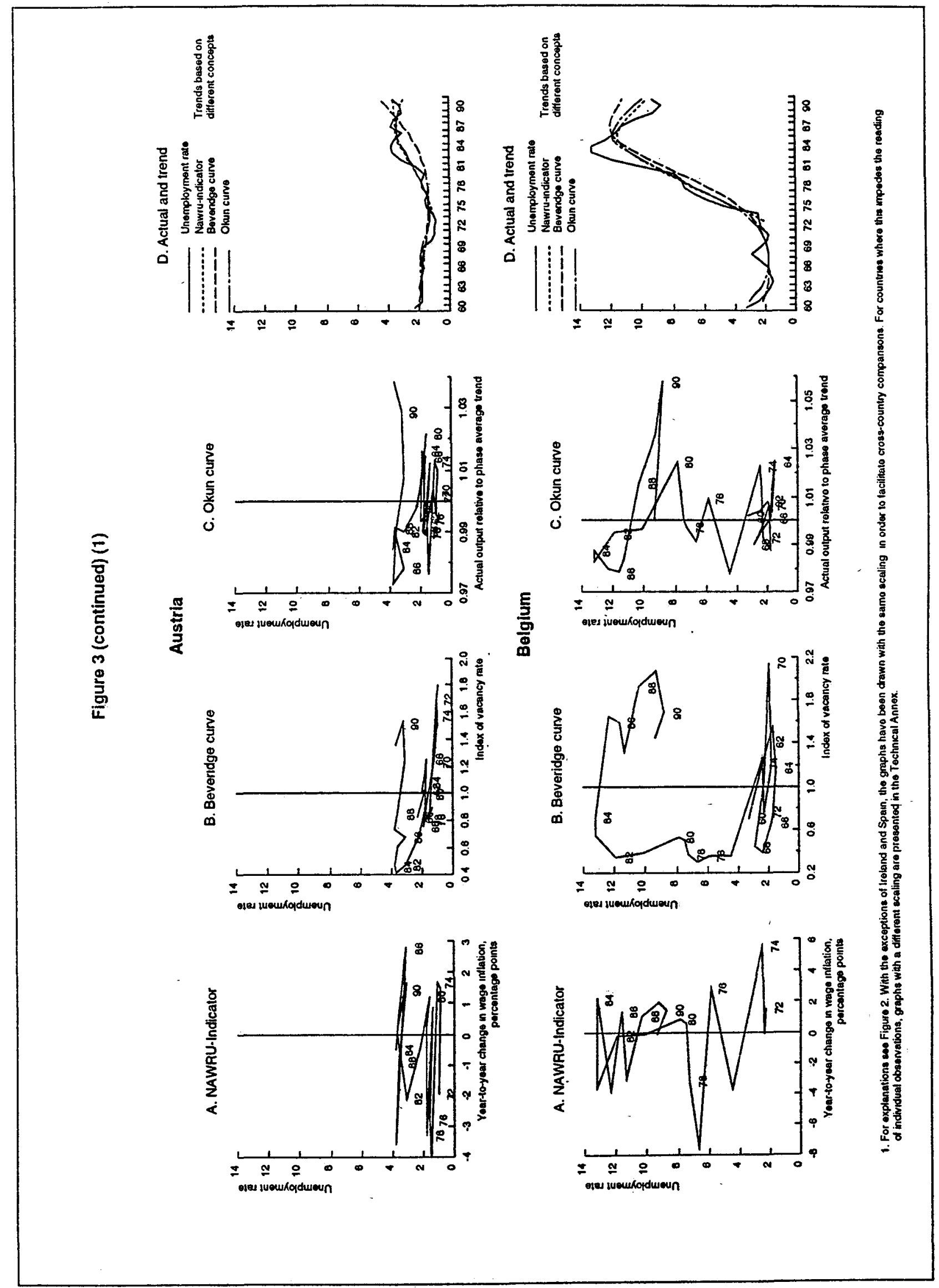




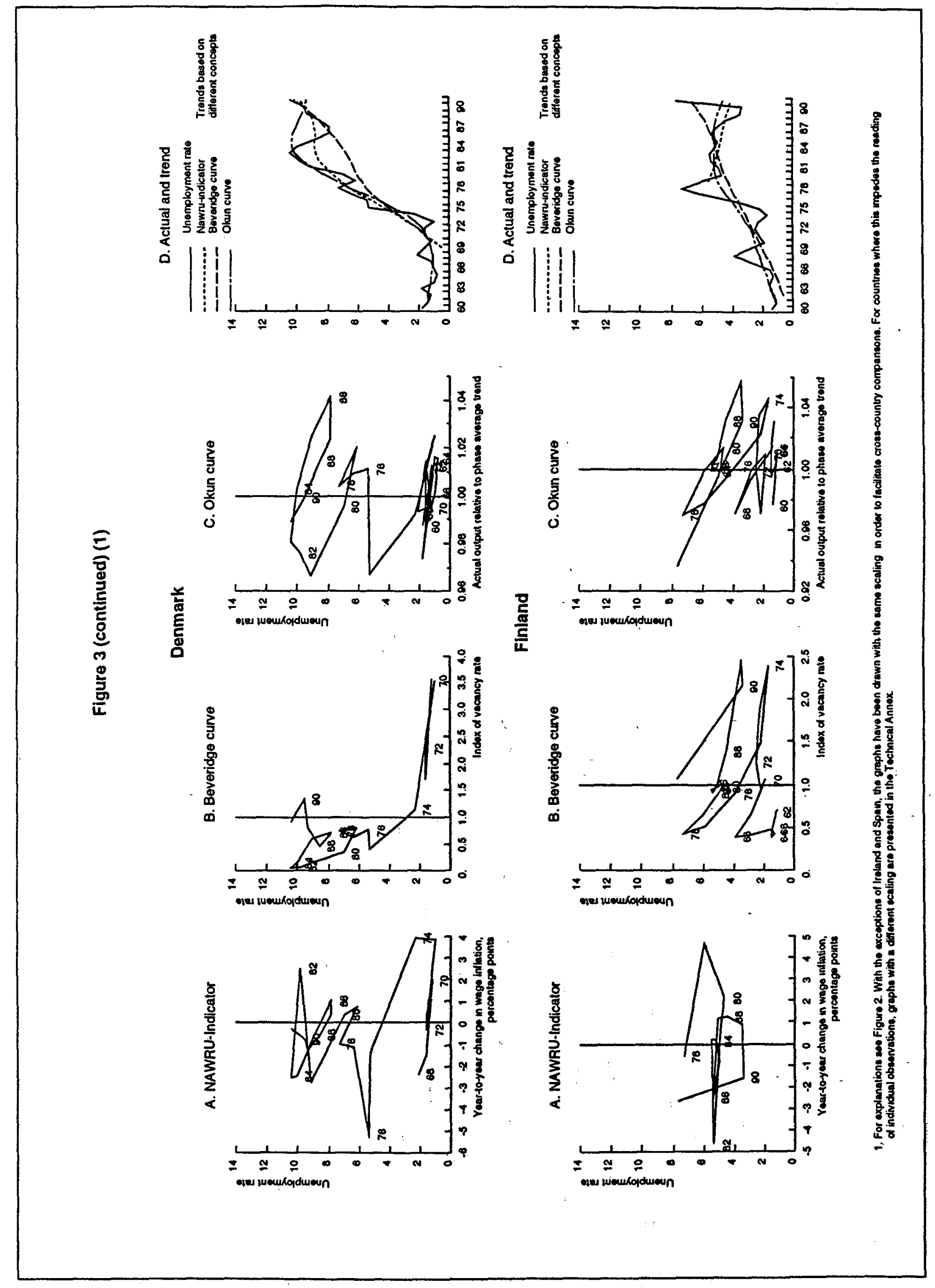




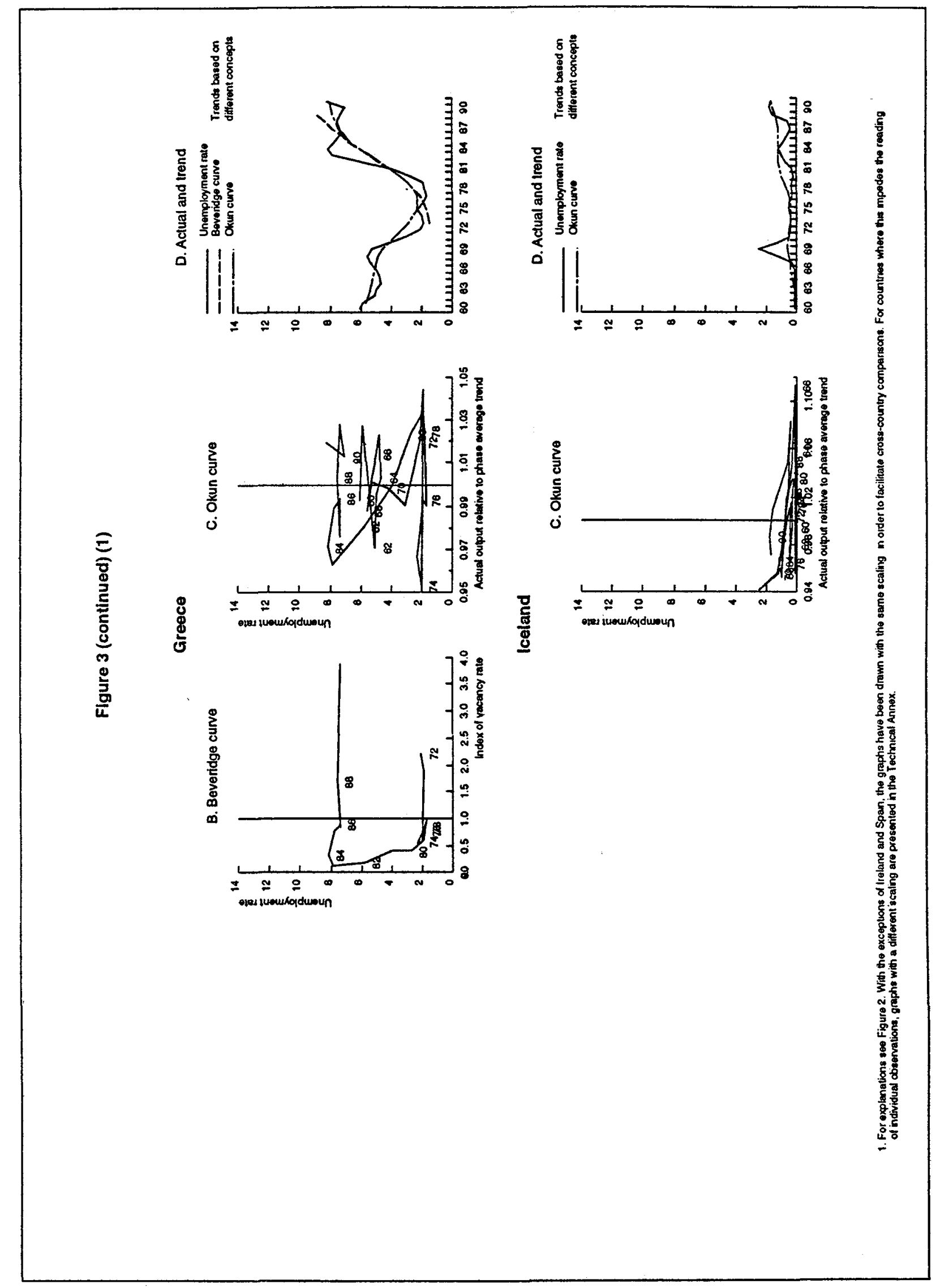




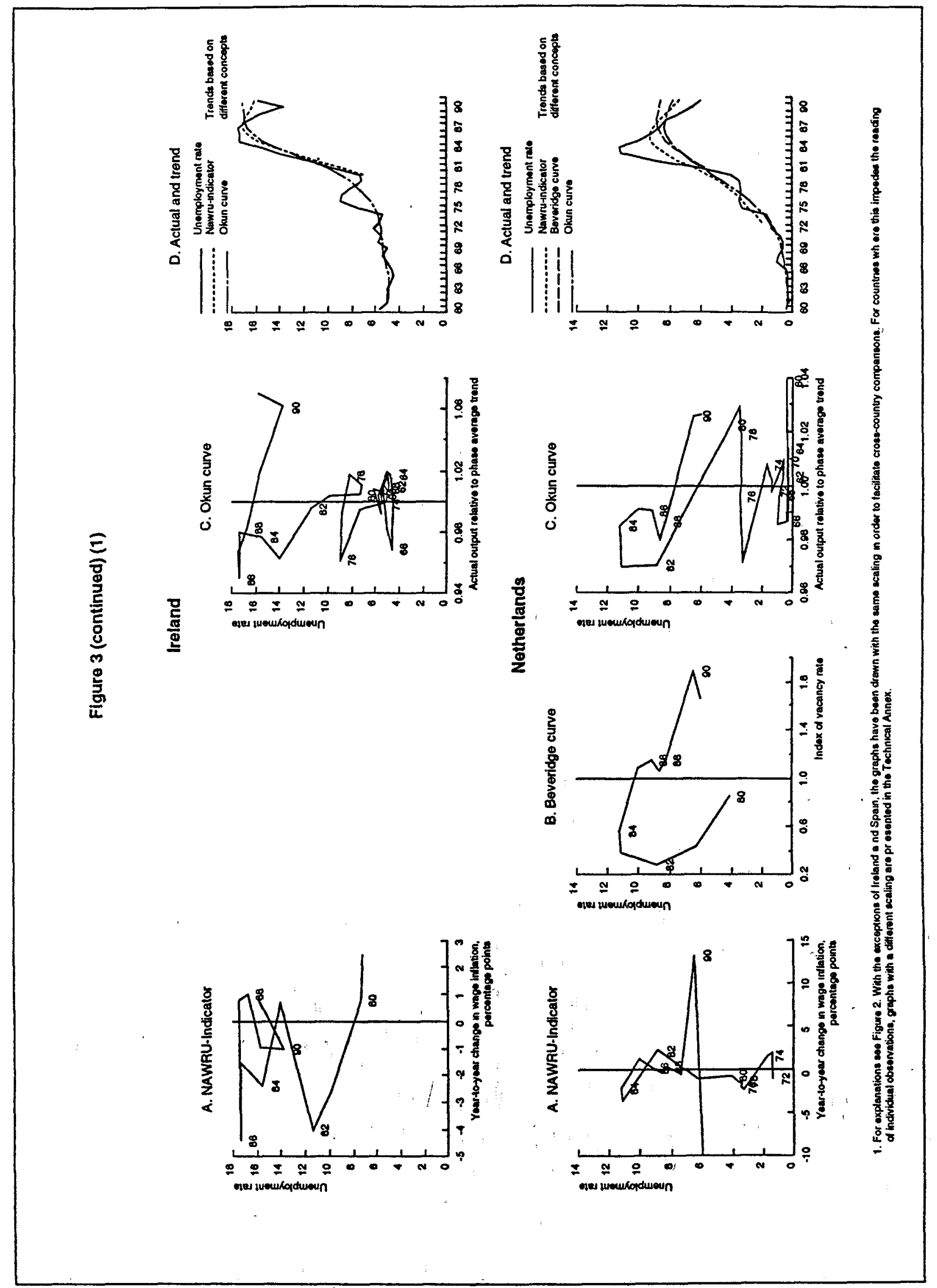




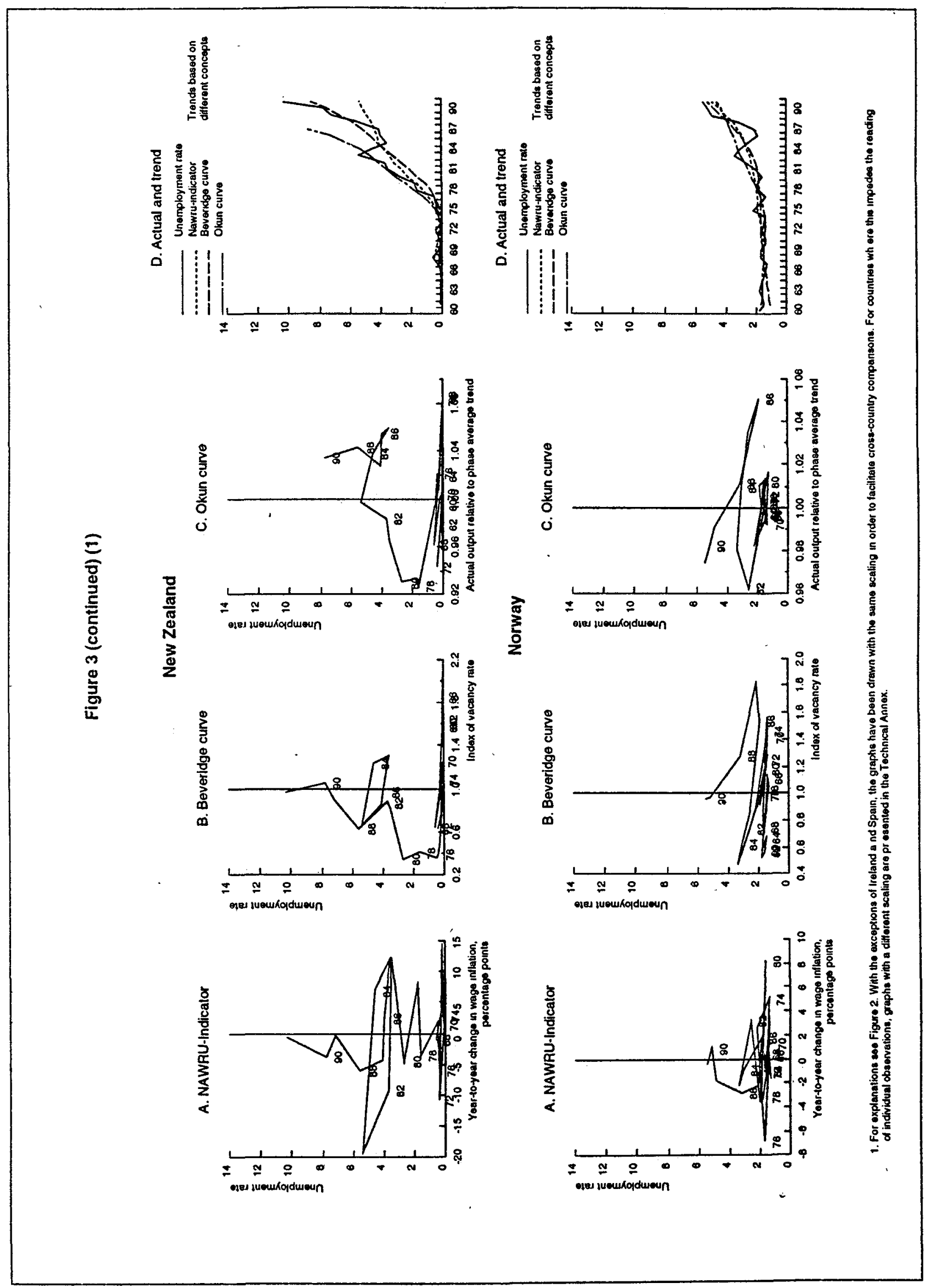




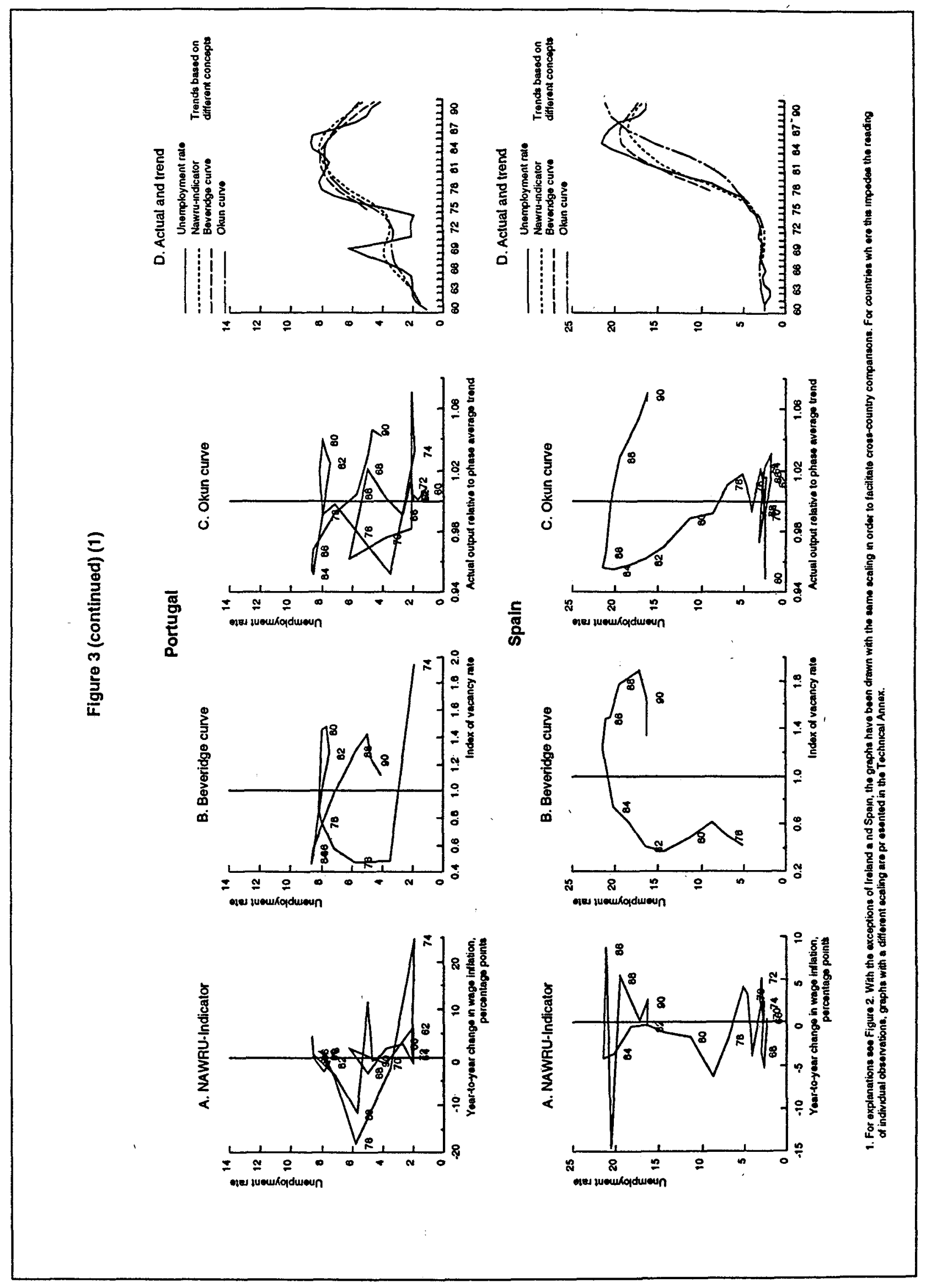




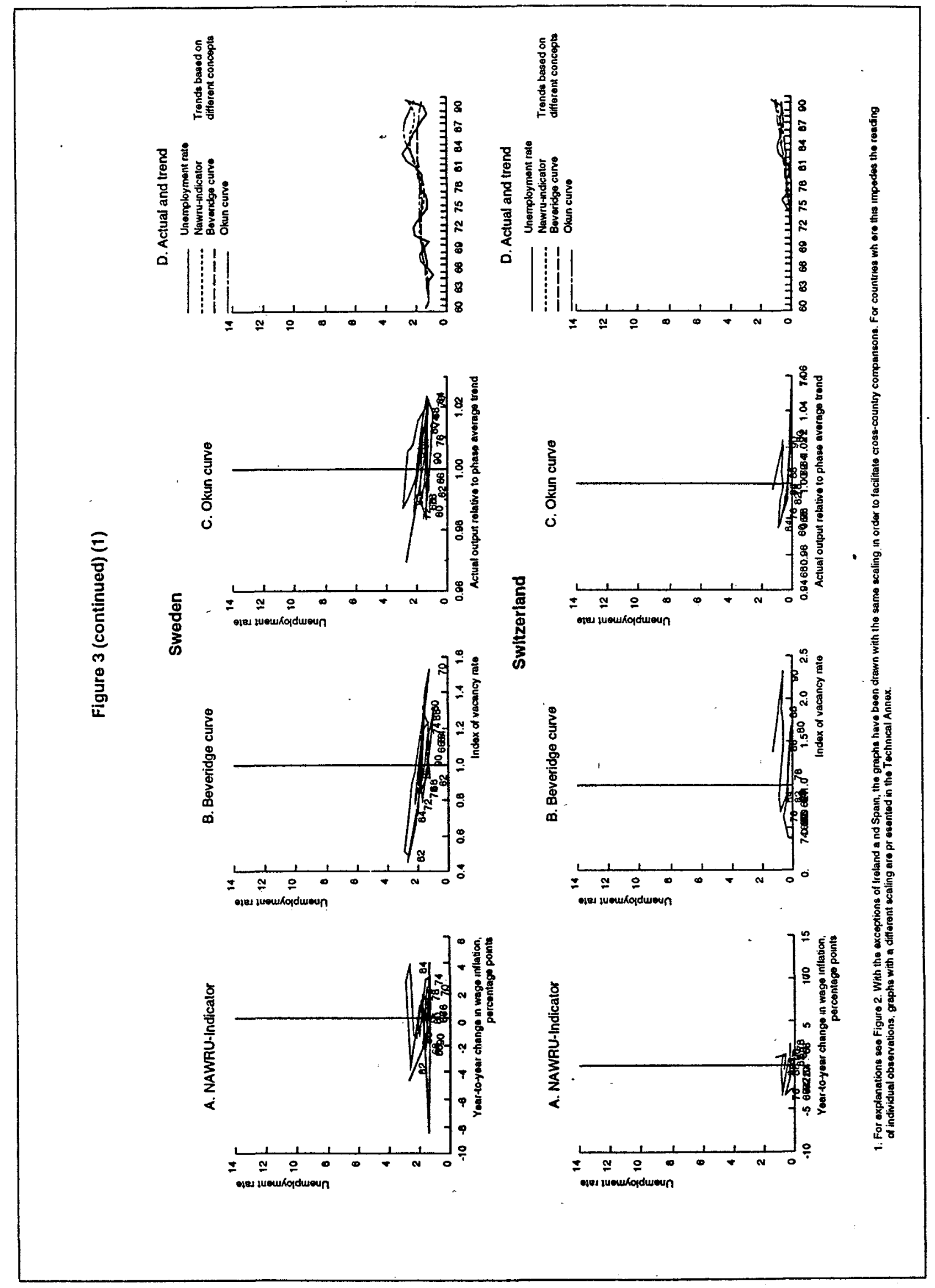




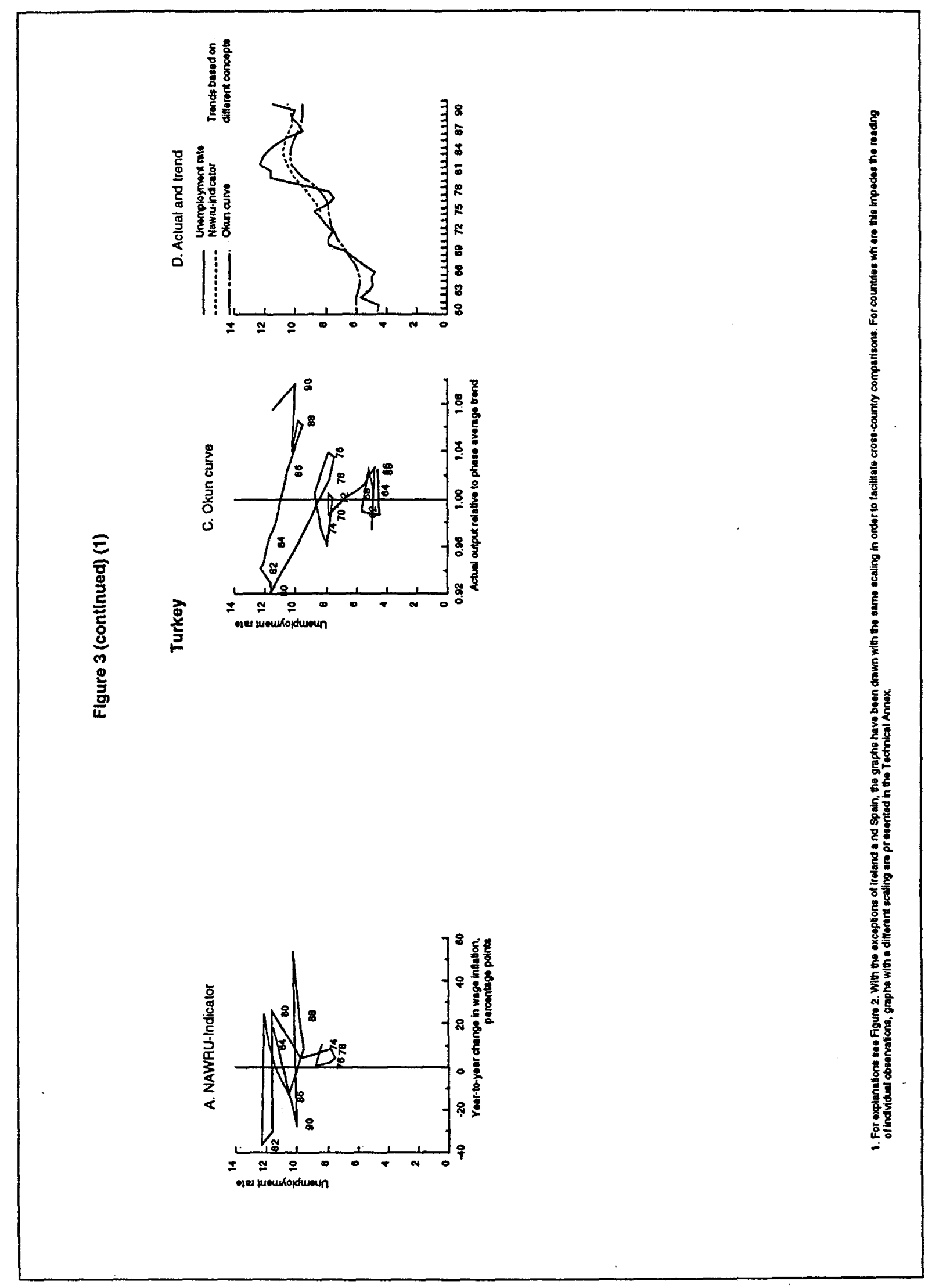


Figure 4. Cycllcallty and trend rise of unemployment (percentage points)

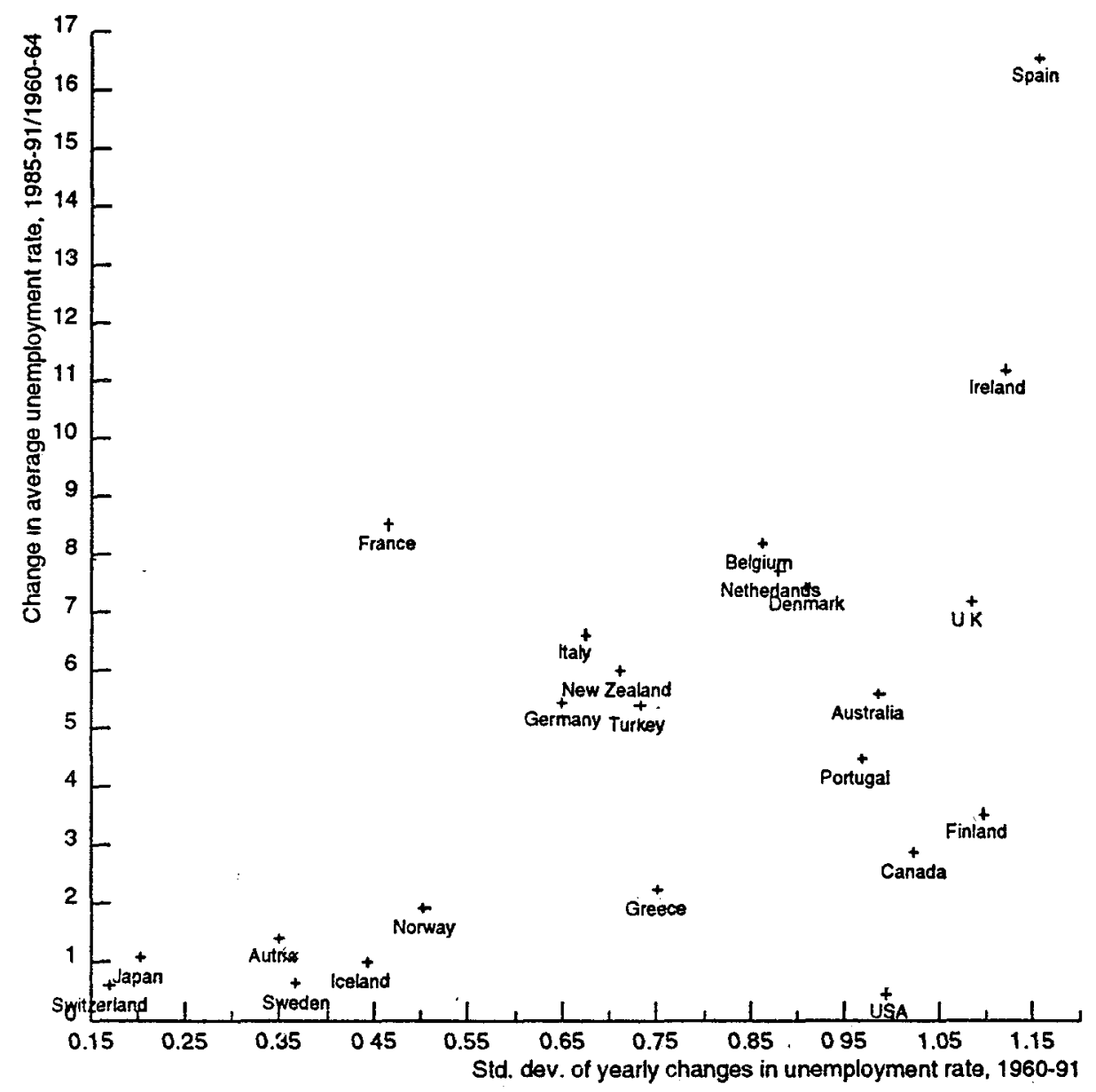


Figure 5. Wage shares in the business sector
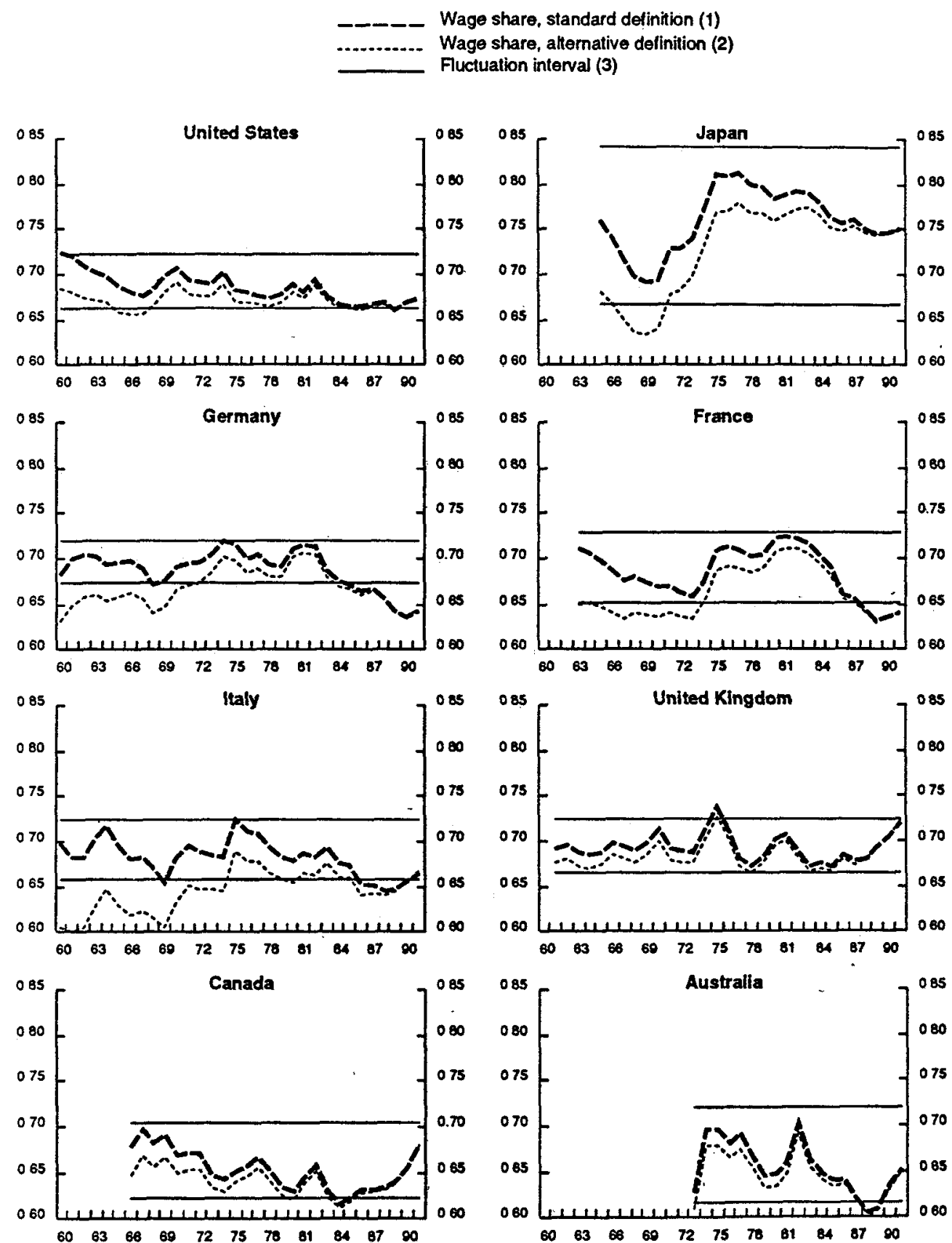

1 Calculated by imputing a wage compenzation to selt-employed equal to average componzation for wages camere. Cin 1900 to by uting a wage com

3 Horizontal lines show fluctuation interval over the period up to and inctuding 1980 They have been calculated

as the mean wage share, baed on the fine method, +1 - two times its standard deviation. 
Figure 5 (continued)
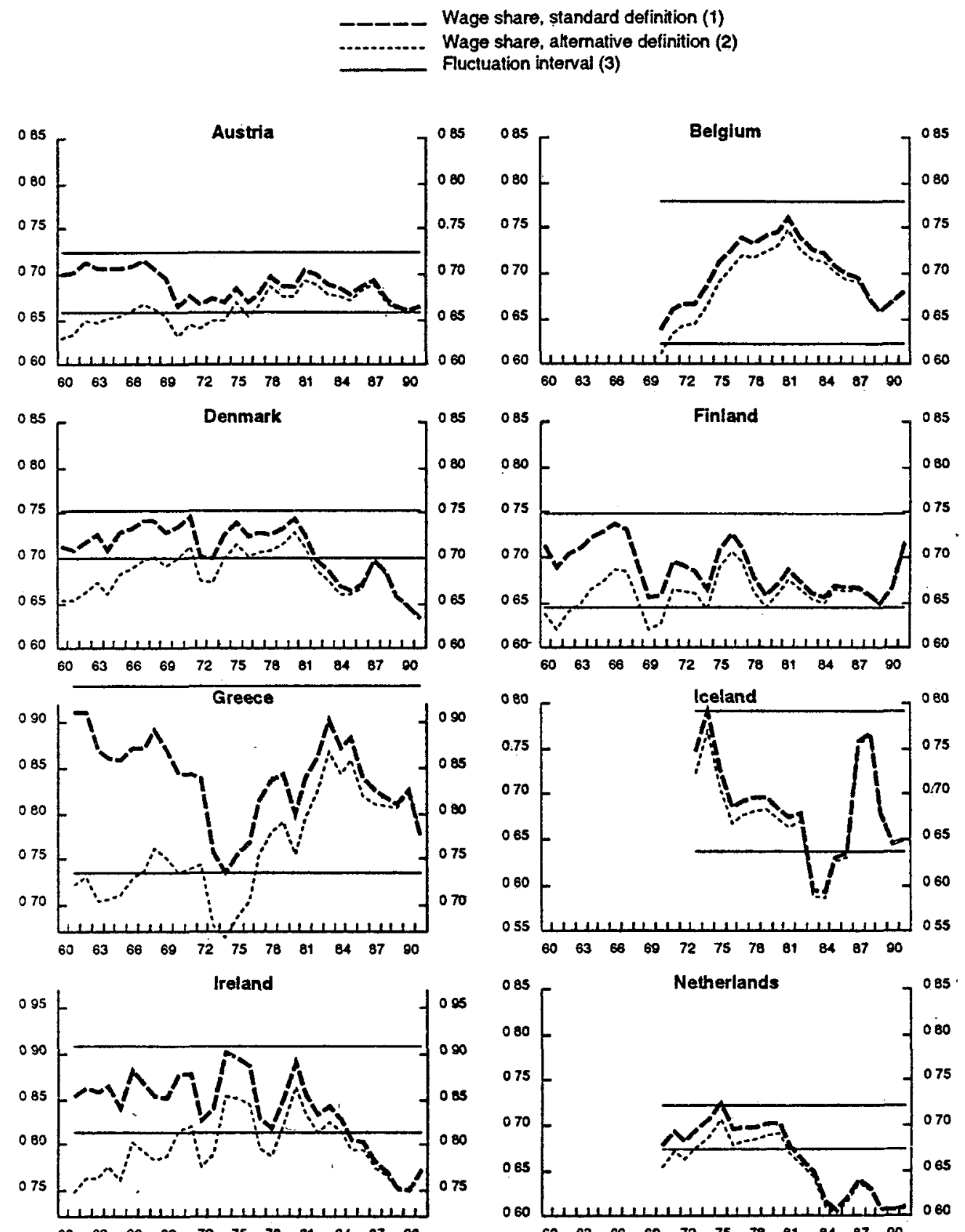

Calculated by imputing a wege compensation to self-employed equal to awerage compenzation for wage eamera 2 Calculated by imputing a wage compensation to selfi-mployed rising from 70 per cent of average compensation in 1960 to 100 per cont in 1990

3 Horizontal lines show fluctuation interval over the period up to and including 1980 They have been calculated as the mean wage share, based on the first method, +1 - wo times its standerd doviation. 
Figure 5 (continued)

_____- Wage share, standard definition (1)

............ Wage share, altemative definition (2)

Fluctuation interval (3)
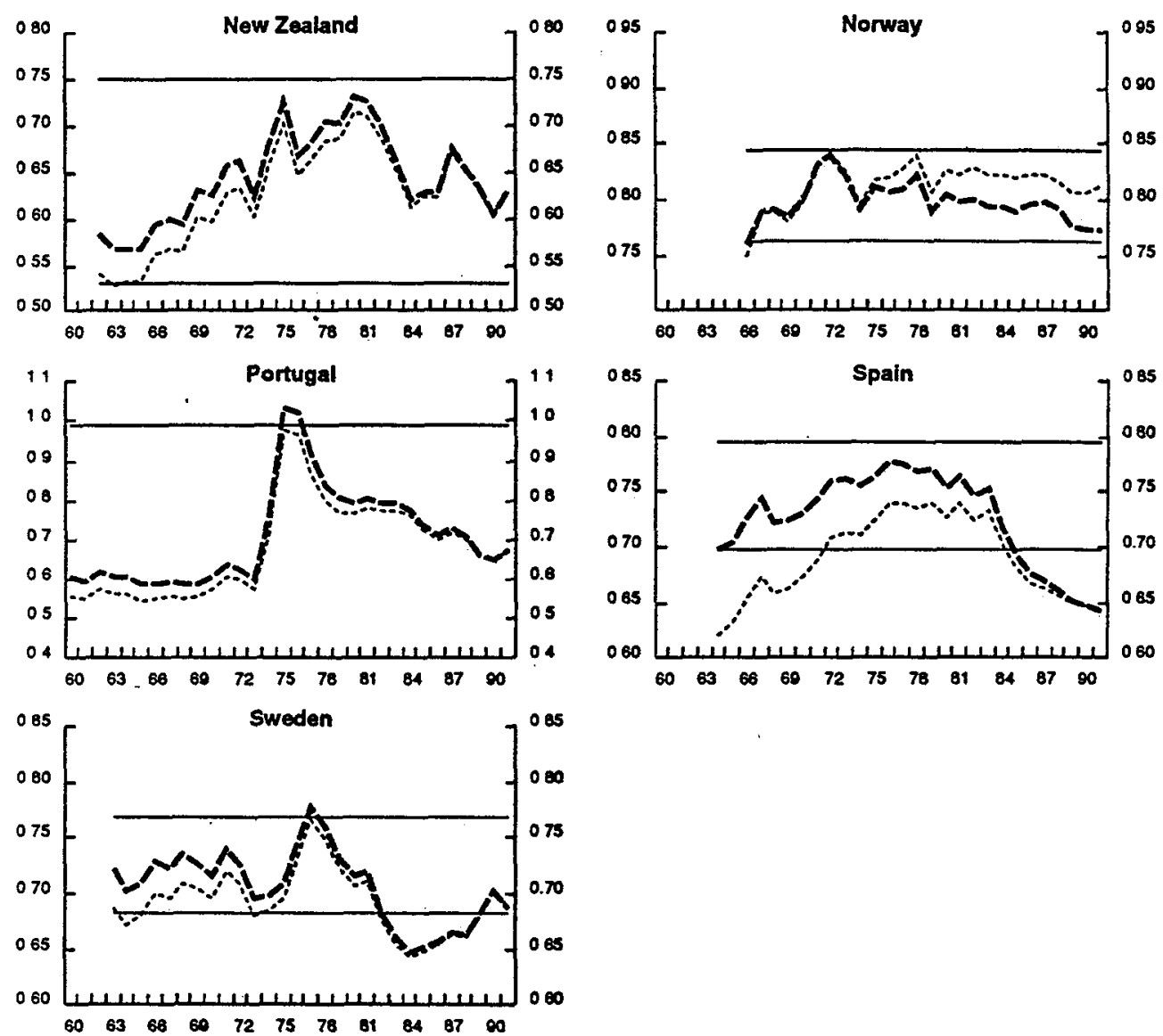

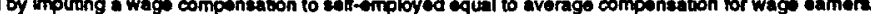
2 Calculated by imputing a wage componsation to sall-employed riaing from 70 par cont of averege compensation in 1960 to 100 per cont in 1900

3 Horizontal lines show fluctuation interval over the period up to and including 1980. Thay have been calculated as the mean wage share, baeed on the firz method, + - wo times ks standard doviation. 
Figure 6. Real wage and marginal product of labour (Indices, average from first year to $1980=100$ )

Real product wage

Cobb-Douglas

Marginal products of production functions

CES function (sigma $=1 / 3)$

calibrated for the period up to 1980
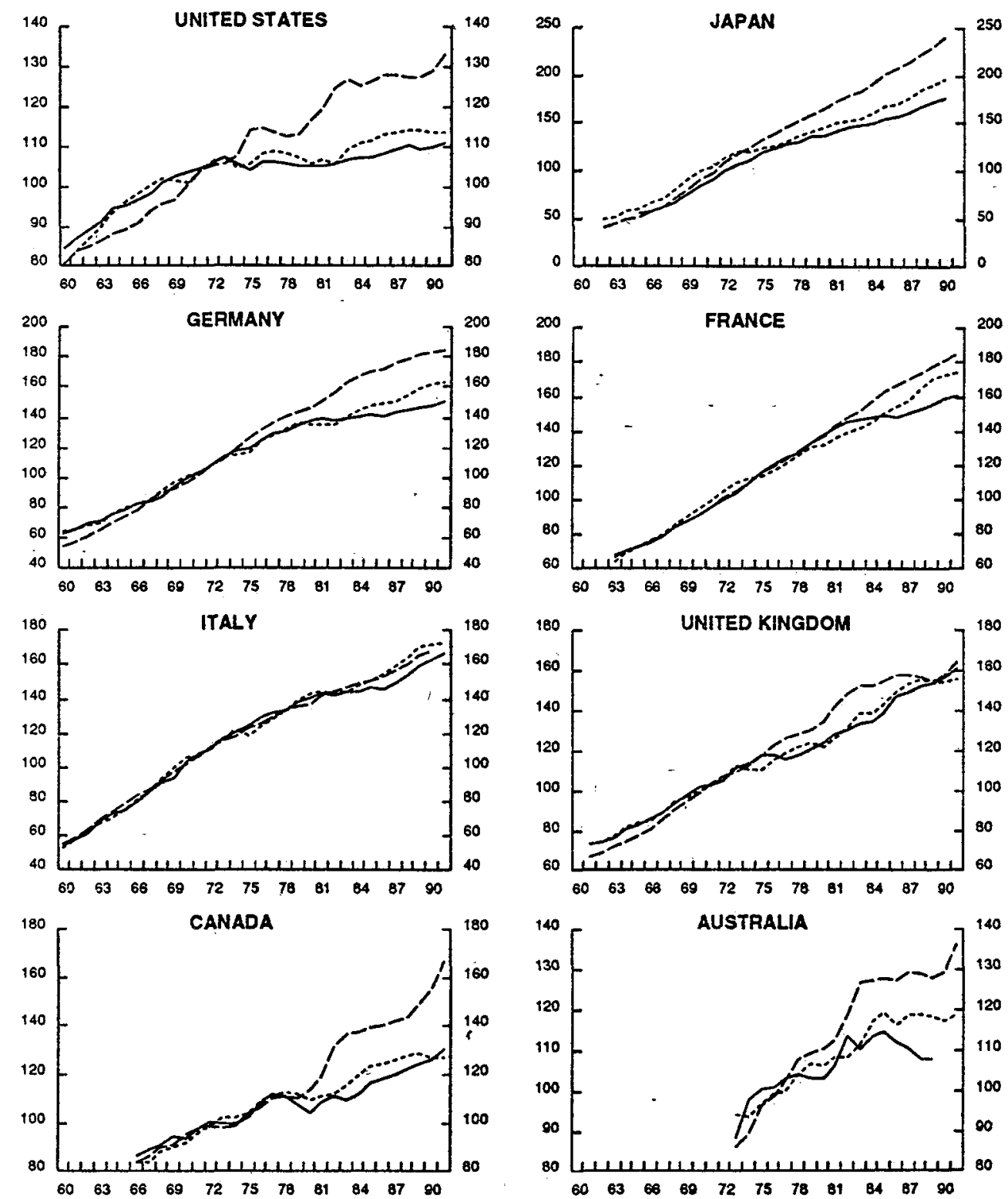
Figure 6 (continued)

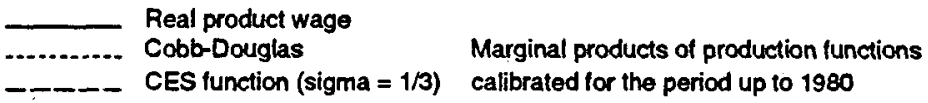
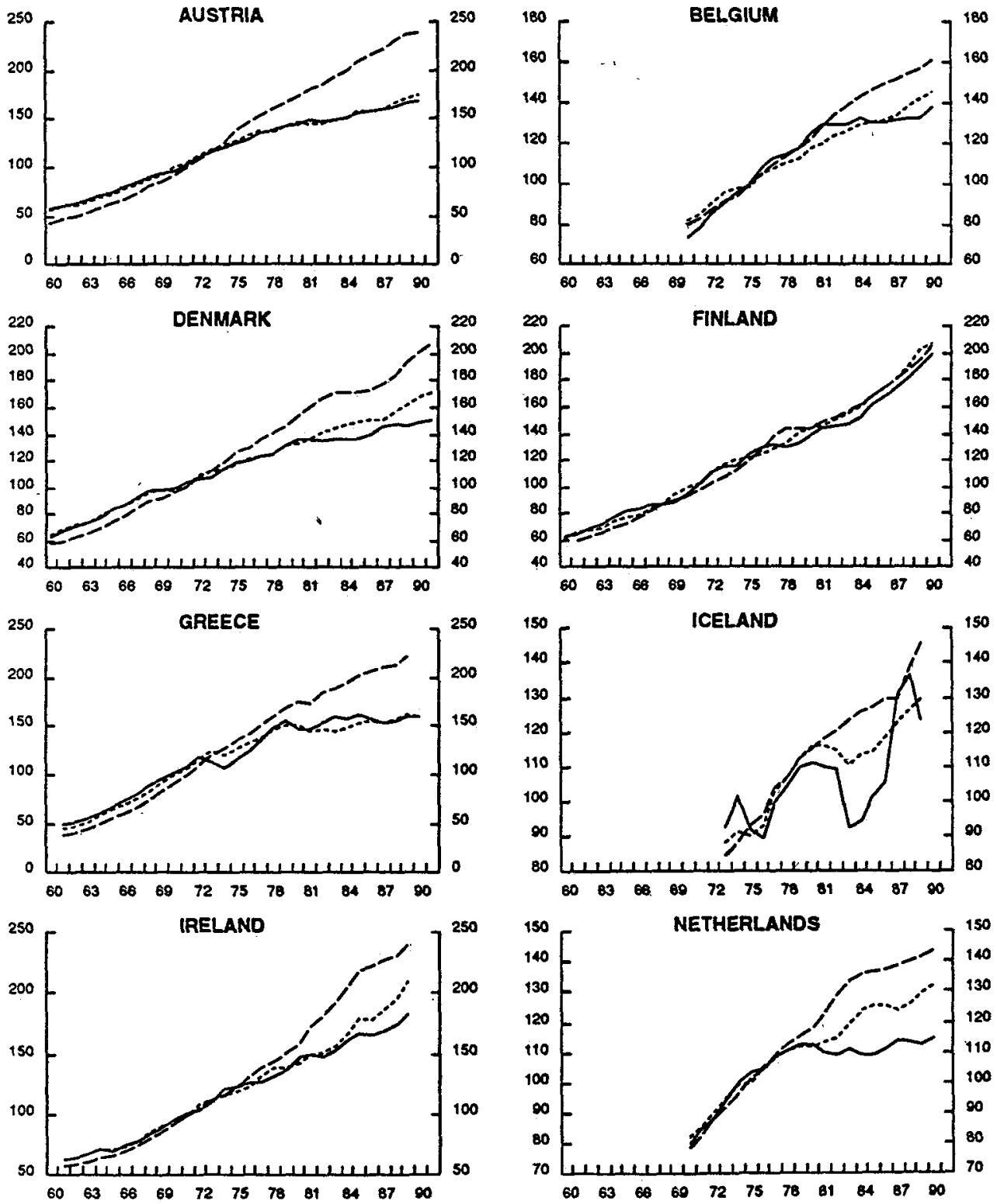
Flgure $\mathbf{6}$ (contInued)

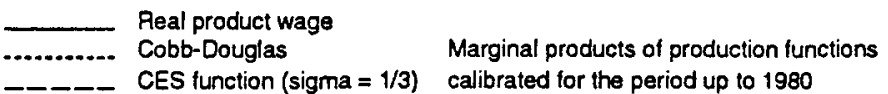
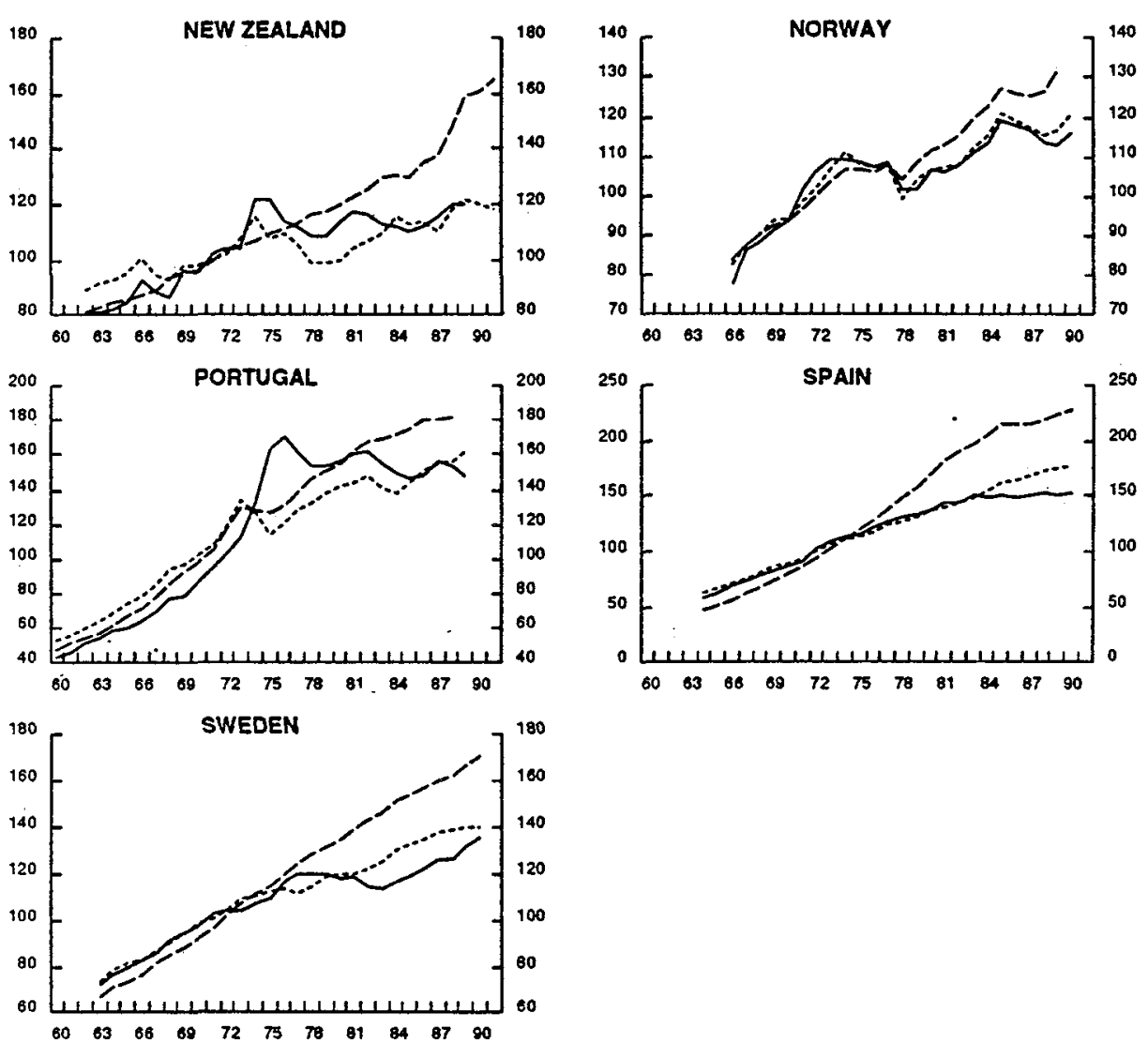
Figure 7. Impact of demography on the unemployment rate (1)
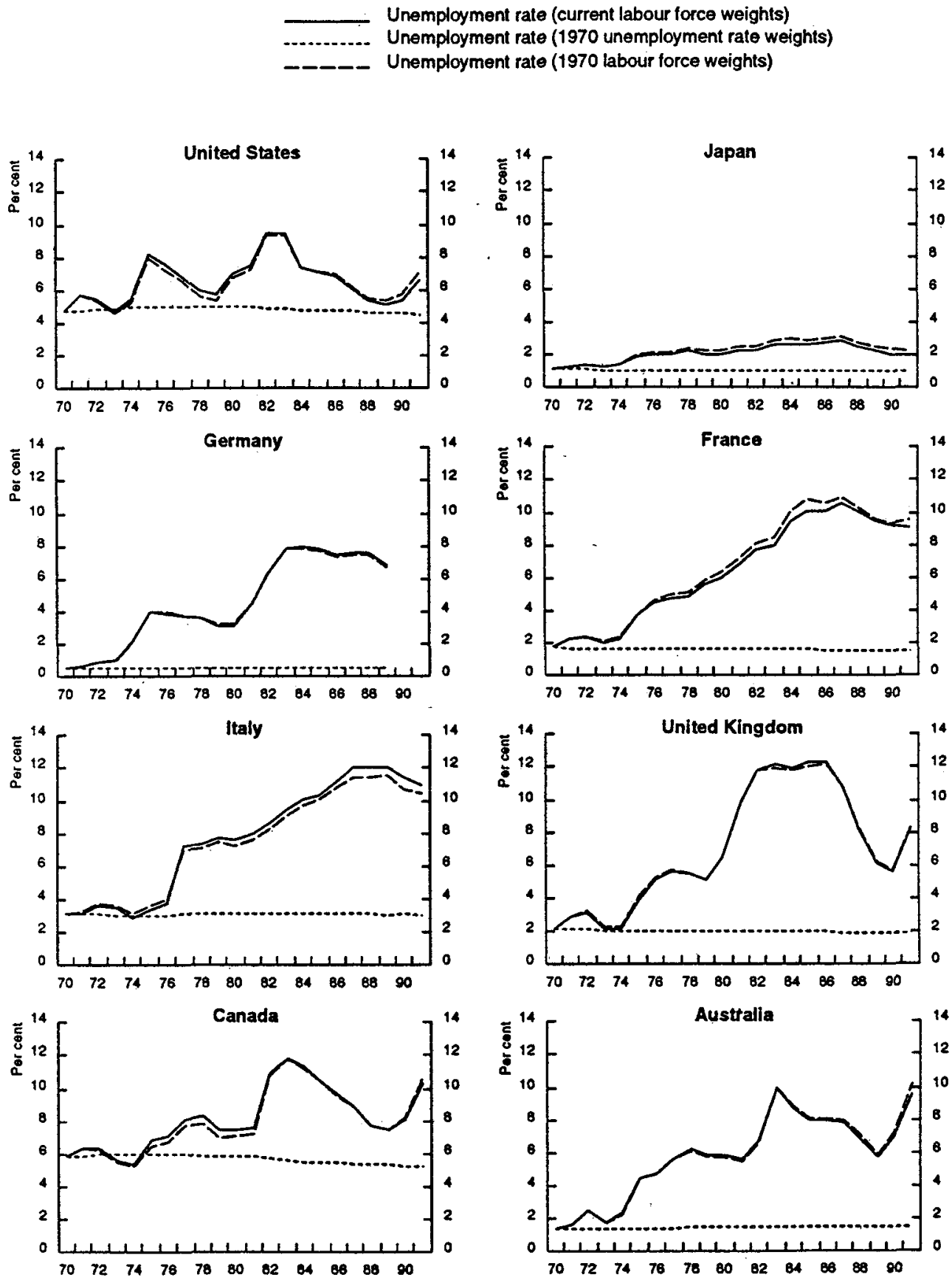

1 Scales differ in the casess of Iroland, Nothertands and Spain 
Figure 7 (continued) (1)
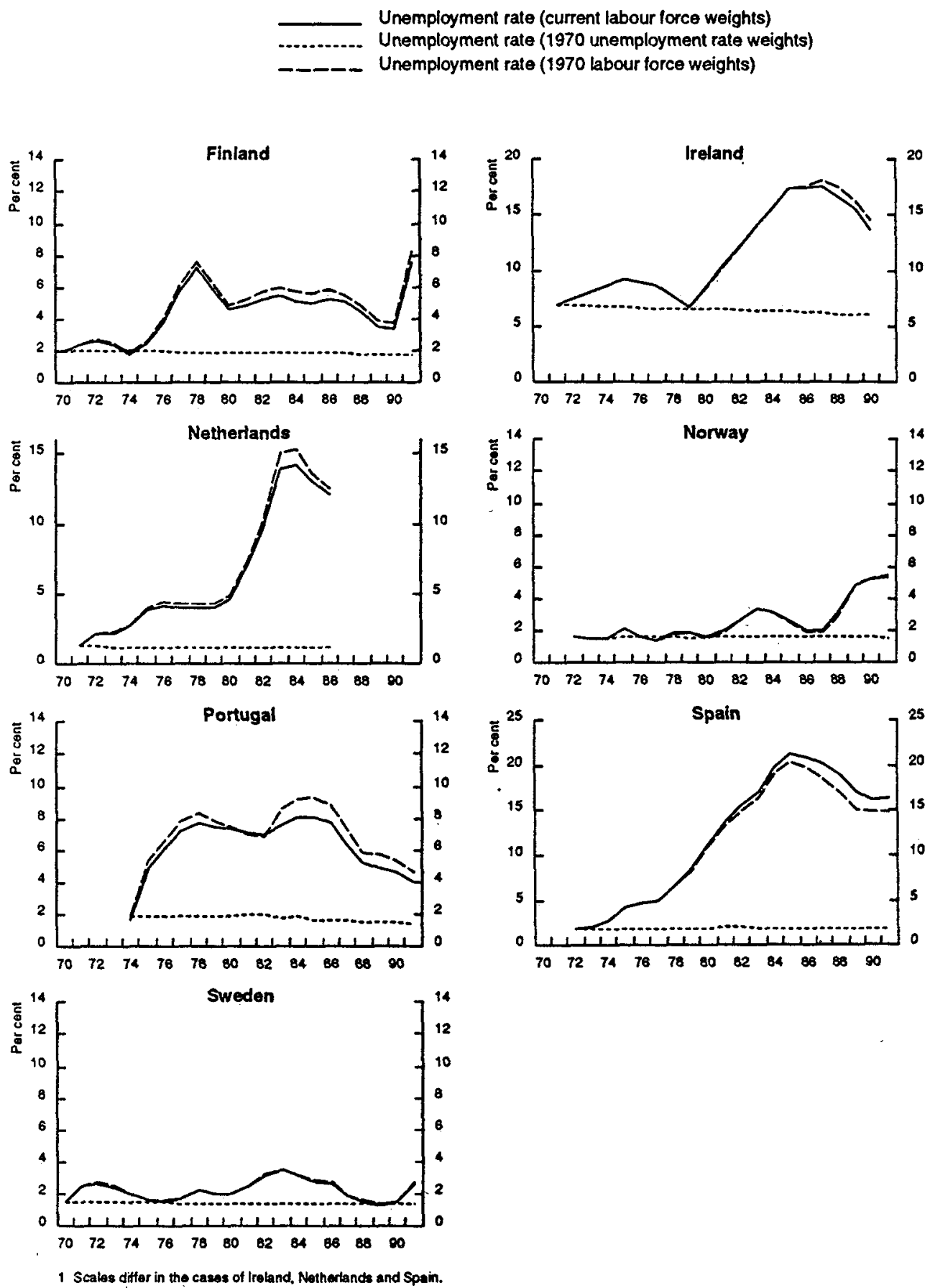
Figure 8. Unemployment rates for certaln cohorts relatlve to total unemployment rate (1).
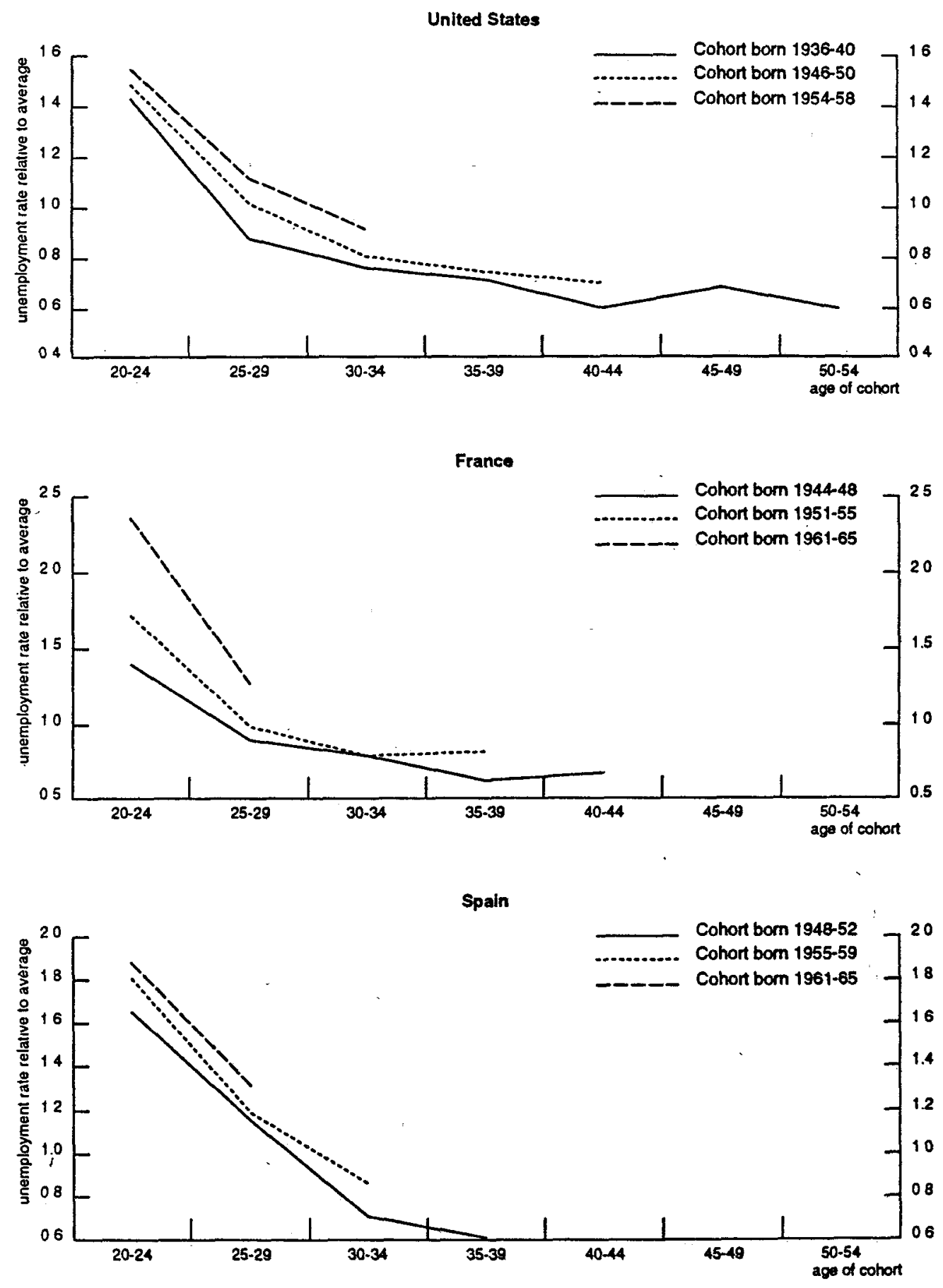

1 The diagram shows age-group specilic unemployment rates relative to overall unemployment rates for given population cohorts as these pass through different age brackets. 
Figure 9. Indicators of sectoral and regional employment change and turbulence (1)
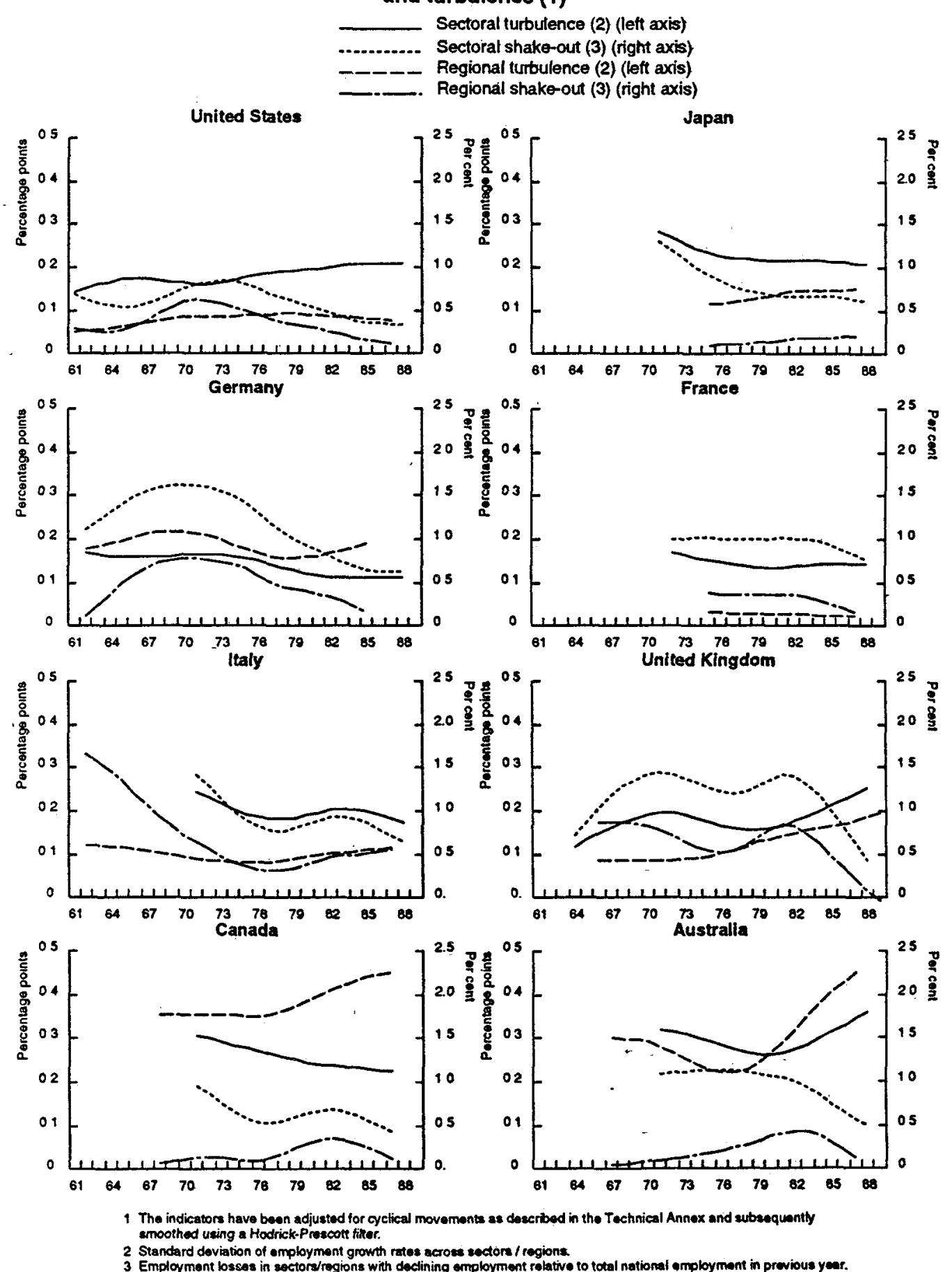

The indicators have beon adjusted for cy

Slanctard doviation of employment grouth rates acrose sectors

3 Employment losses in sectory/egions with declining employment ralativo to total national amployment in previous yeer. 
Figure 9 (continued) (1)
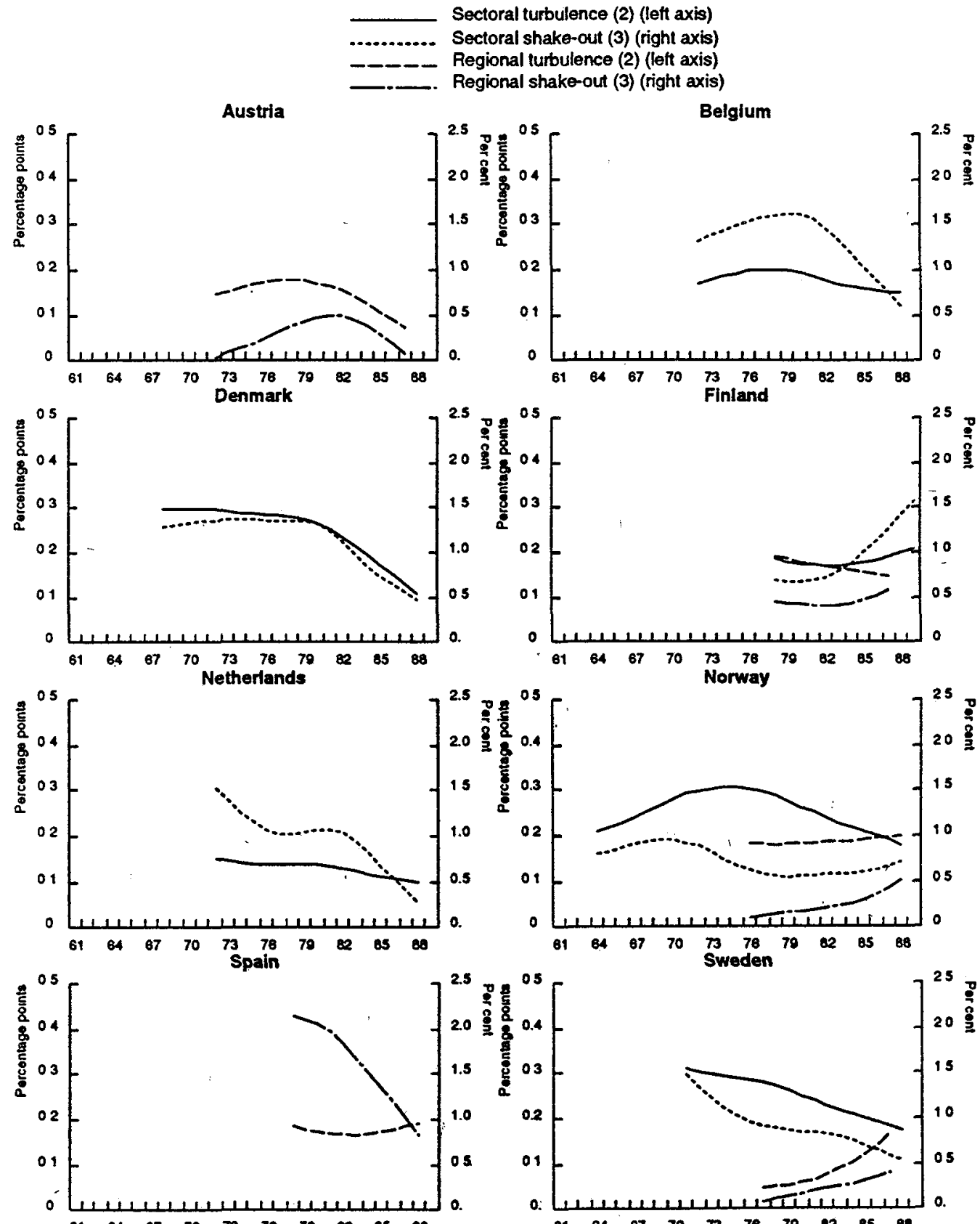

The indicators have been adjusted for cyclical movements as described in the Technical Annox and ruberequently smoothed using a Hodrick.P Prescott fiter.

Stanctard doviation of employment growth rates acrose cectors / regions.

3 Employment losess in sectors/regions with declining employment reletive to total national employment in previous year 
Figure 10. Seasonal variations of unemployment rates (1)
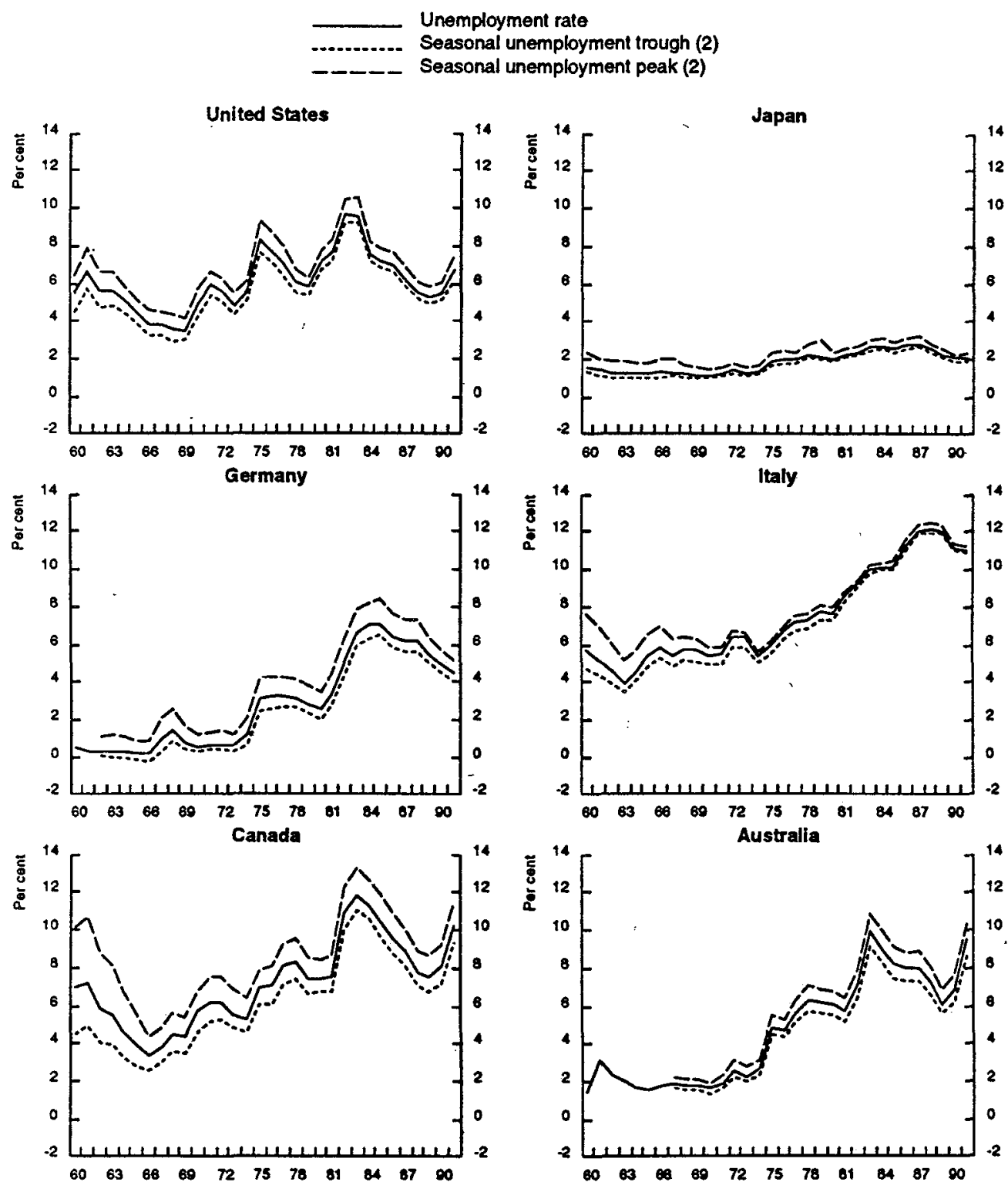

1. The ecale is dittereme in the case of lroband

2 The maximum nogative and positive doviationa between available monthly indicator of actual and wasonally adjusted 2 The maximum negative and postive doviations befween available monthy indicator of actual and wasonalif 
Flgure 10 (continued) (1)
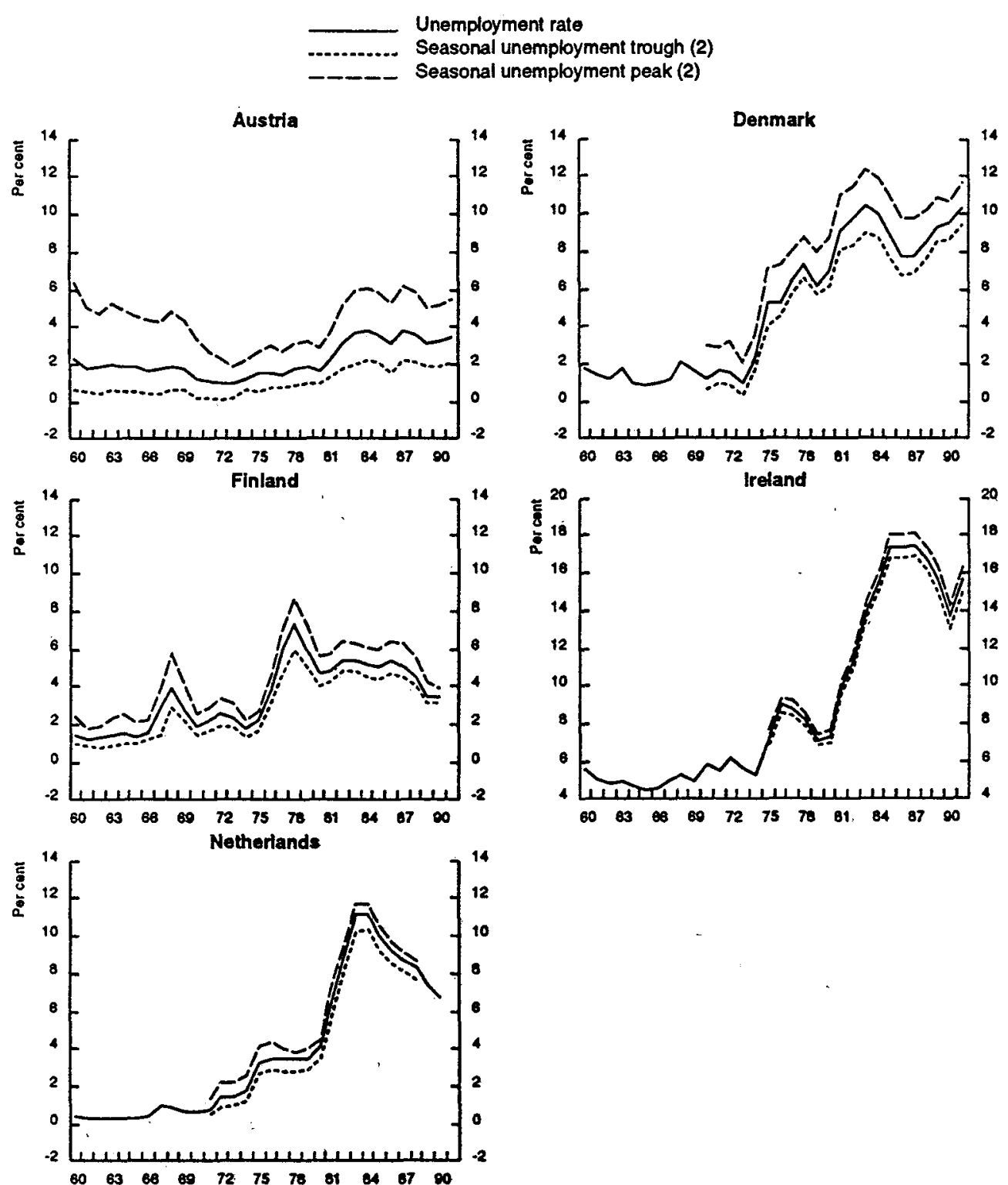

1 The scale is different in the case of lroind

1. The scabo is difiorent in the case of lroiand The maximum negative and positive devintions between aveileble monthy indicator of actual and seasonally 
Figure 11. Short-run real wage rigldity and unemployment Increase

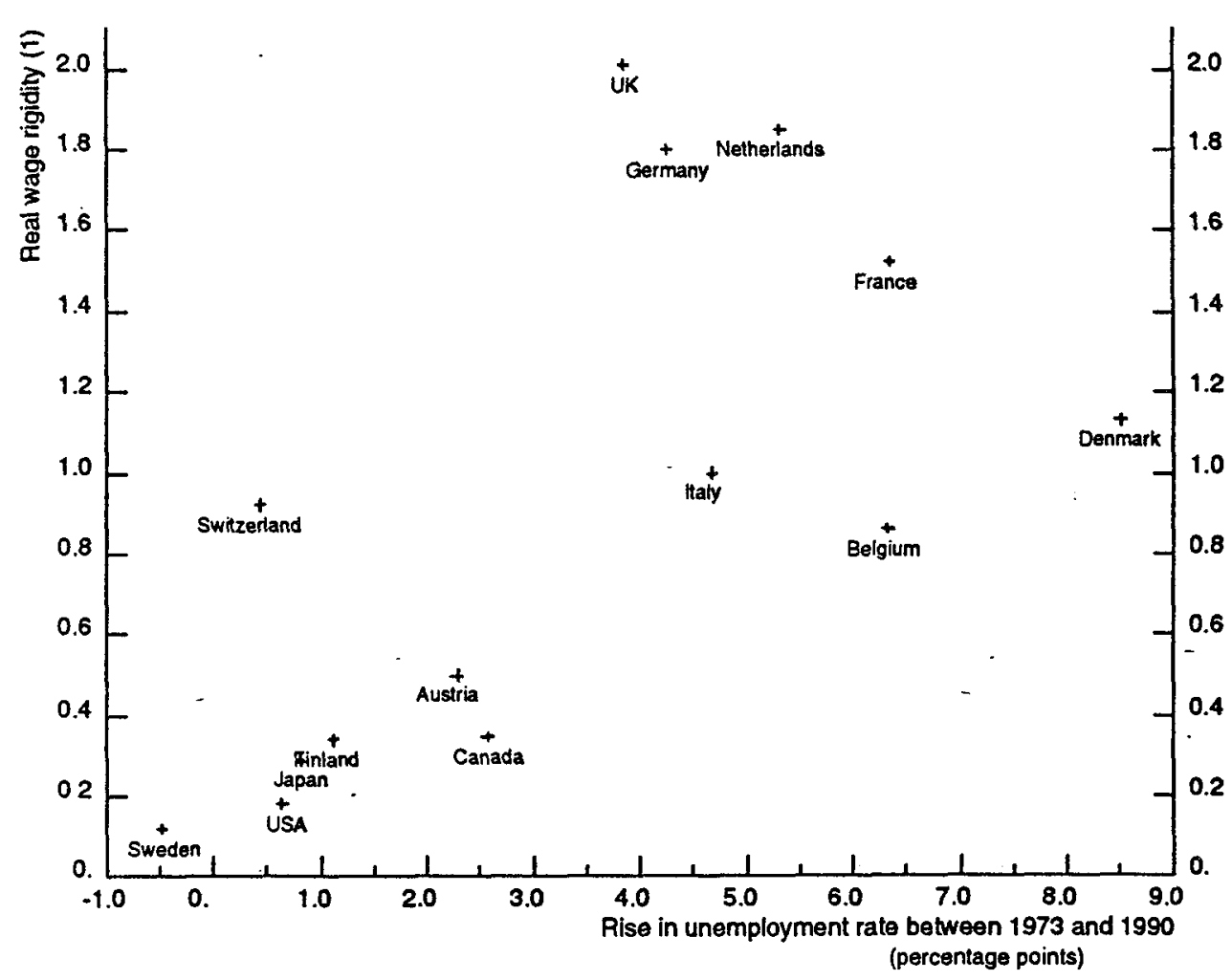

1. Short-run real wage rigidity is measured by the amount of additional unemployment (as per cent of the labour force) needed to offset the short-term wage impact of a one percentage point price shock.

Source: OECD, 1989. 
Figure 12. Real wage rigidity (1) and centrallsation of wage bargalning (2)

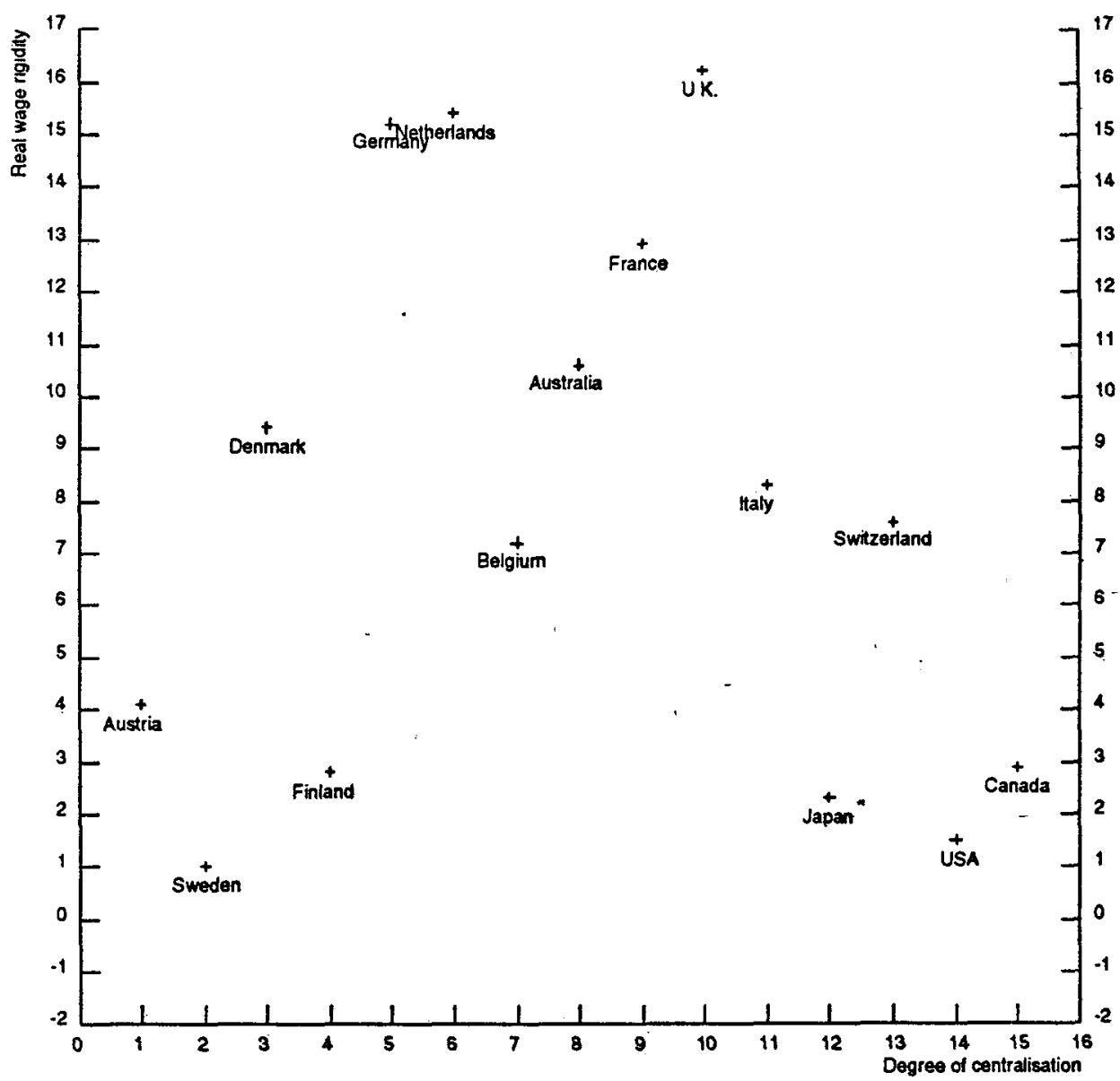

1. Short-run real wage rigidity as measured in OECD (1989).

2. Countries are ranked from the most centralised (close to the origin) to the least centralised. The ranking is that used in Calmfors and Drifill (1988).

Source: OECD,1989. 
Figure 13. Generosity of unemployment benefit systems and the unemployment rate
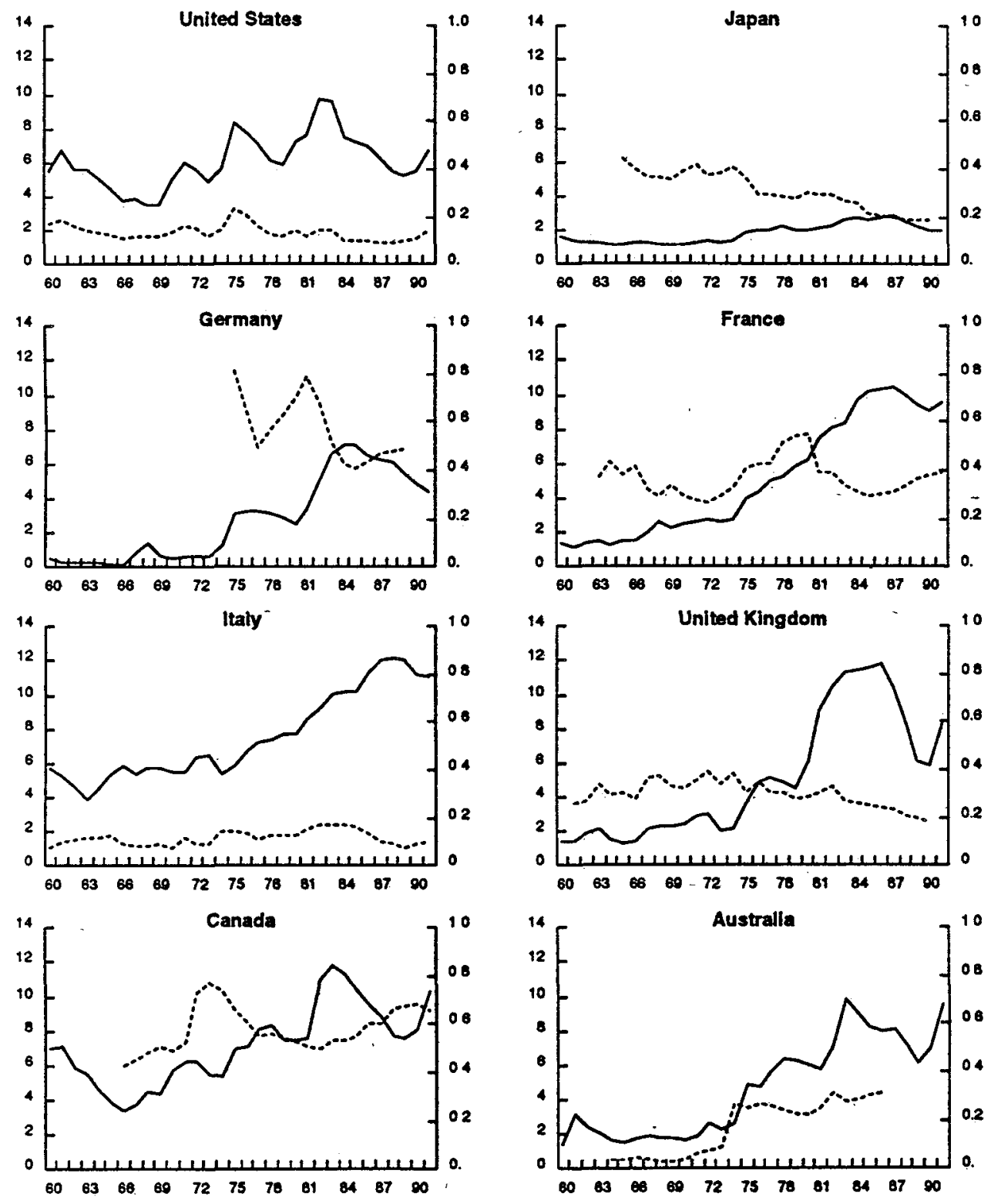

1 Defined as total sponding on ULUA programmes per unemployed panon divided by the sverage wage, which has been derived as the business ecetor wage bill (excluding employer contrbutions) divided by the number of business aector employece.

By dividing spending on UWUA programmes by botal unemployment instead of just benofie recipients, mapects of generosity such was

maximum duration and eligbility rules ave to some oxtomt taken into sccourx, though changes in theso aspects of generouity

may affect both the numernsor and the denominator of the generosity ratio. Scales are different in the caee of intand and Spain. Source: OECD Analytical Databases and Social Tranafor Database. 
Figure 13 (continued)

\section{Unemployment rate, per cent (left scale)}

Generosity indicator (1) (right scale)
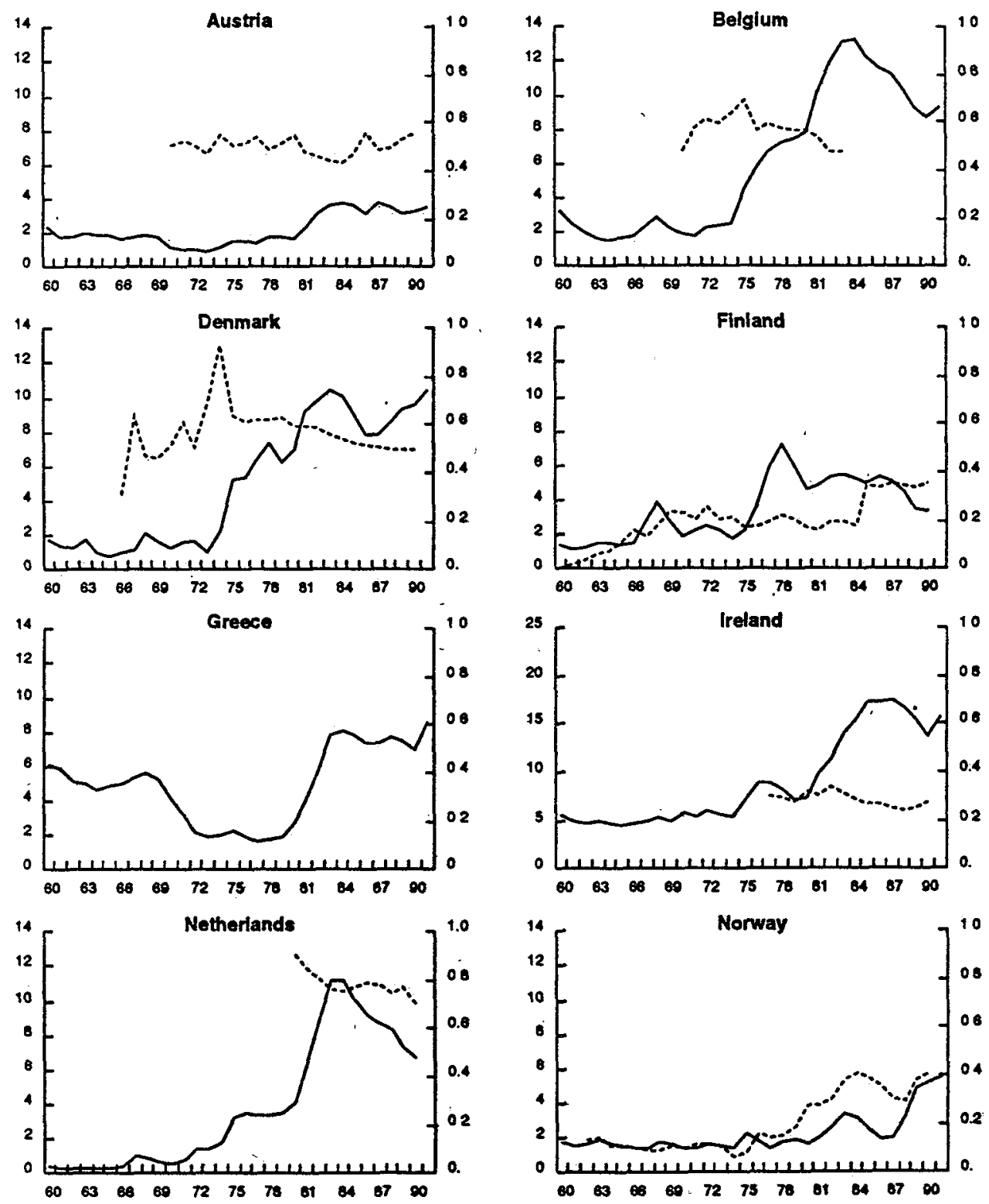

Defined ea total spending on UVUA progremmes per unemployed perion divided by the worege wege, which has beon dorived as the bus inoes esctor wege bill (oxeluding employer contributions) dvided by the number of busineses wector umployeces.

Ey dividing spending on UVRAA programmes by bolal unemployment inatoed of just bonefit recipionts, appects of generosity such a: maximum duration and eligbility rules sere to soms axtent taken into sccoum, though chenges in these aspecte of generovity may affect both the numerator and the denominator of the generesity ratio. Scales are different in the case of lrotand and Spain. Source: OECD Analytical Database and Sociel Traneter Datebase. 
Flgure 13 (continued)

Unemployment rate, per cent (left scale)

Generosity indicator (1) (right scale)
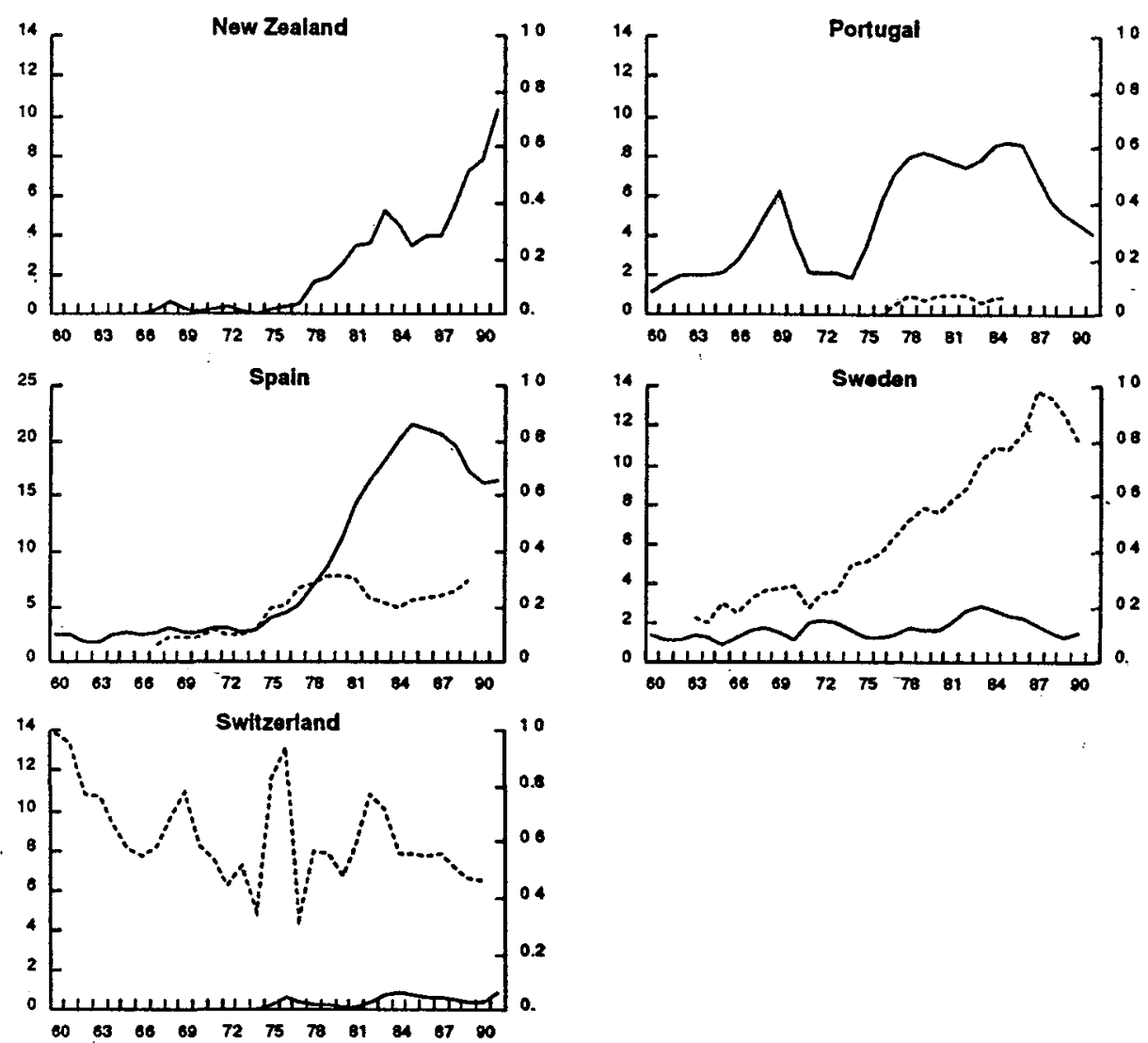

1 Defined es total spending on UIUA programmes per comomployed pereon divided by the everage wage, which has been derived as the business sector wage bill (oxctuding amployer contritutions) dvided by the nimber of business sector employees

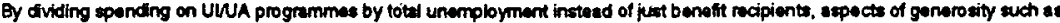

maximum duraton and oligibility nies aro to some extent taken into sccound, though changes in these aspects of generosity

may affect both the numerator end the denominator of the generosty ratlo Scales are difforent in the cases of trestand and Spain.

Source: OECO Analysicel Database and Social Trenstor Databese 


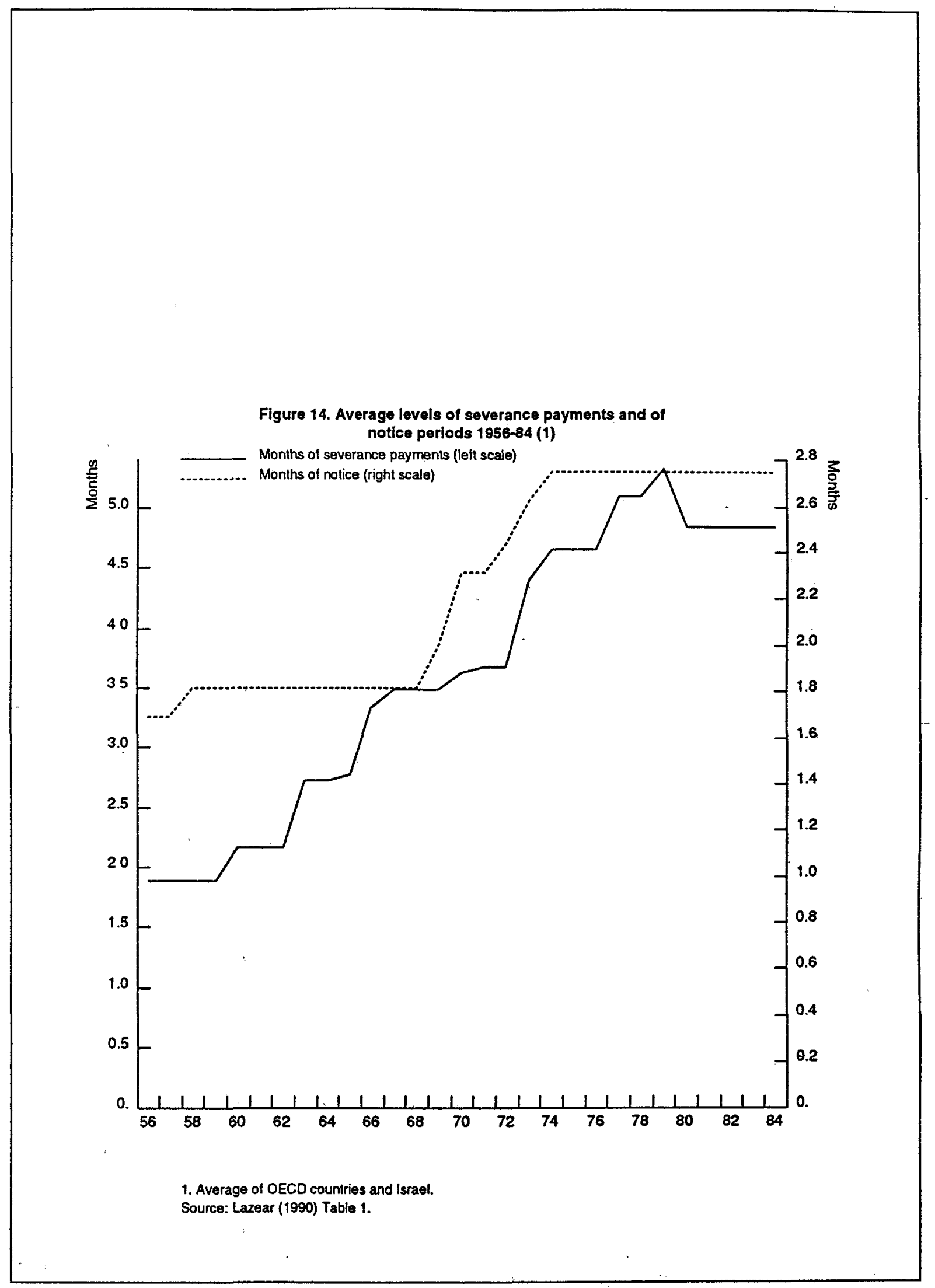


Figure 15. Trends In unemploment rates and annual working hours across countrles, 1970-91 (1)

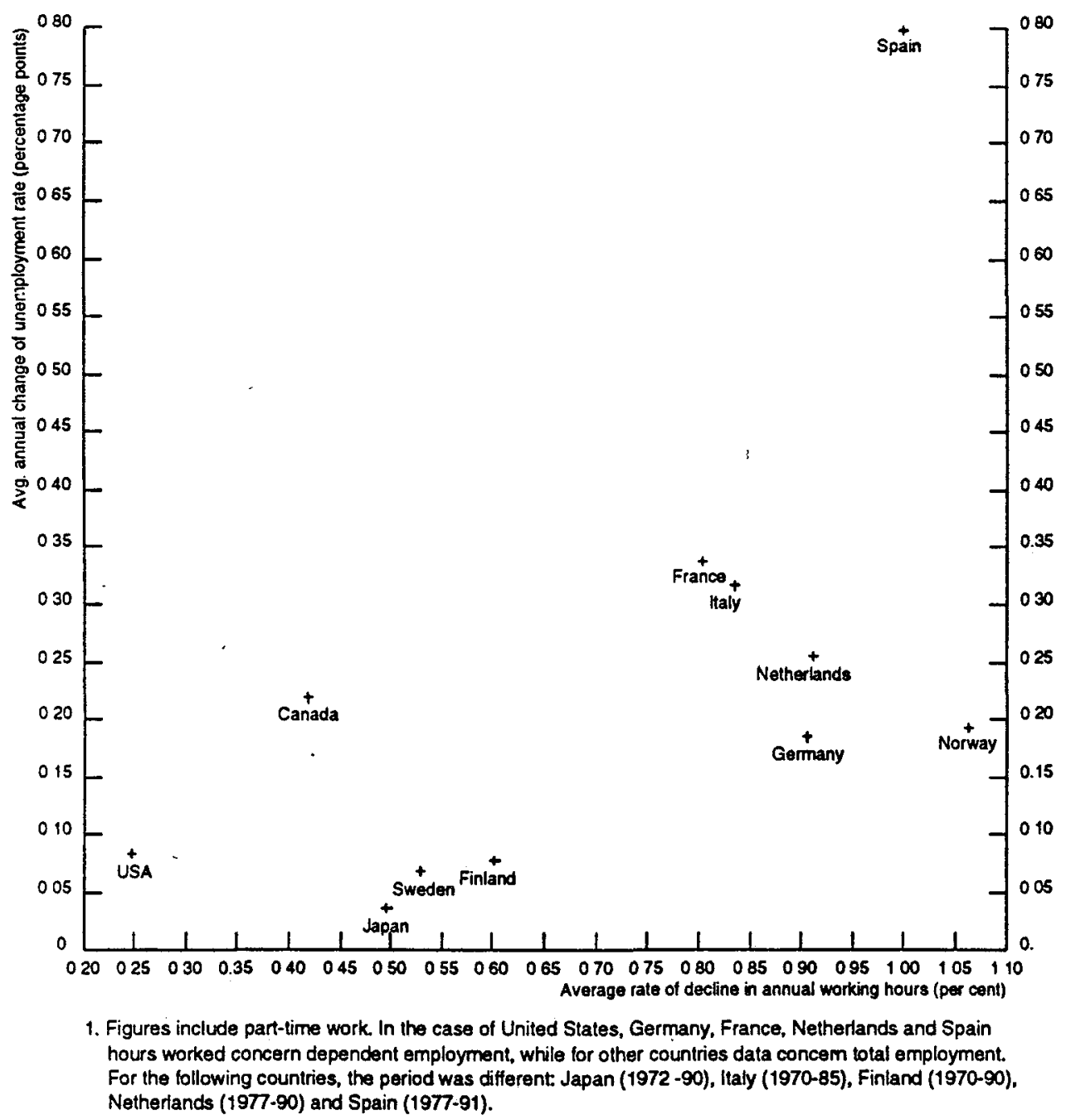


Figure 16. Relative minimum wage and the relation between youth and prime-age unemployment rates (1)
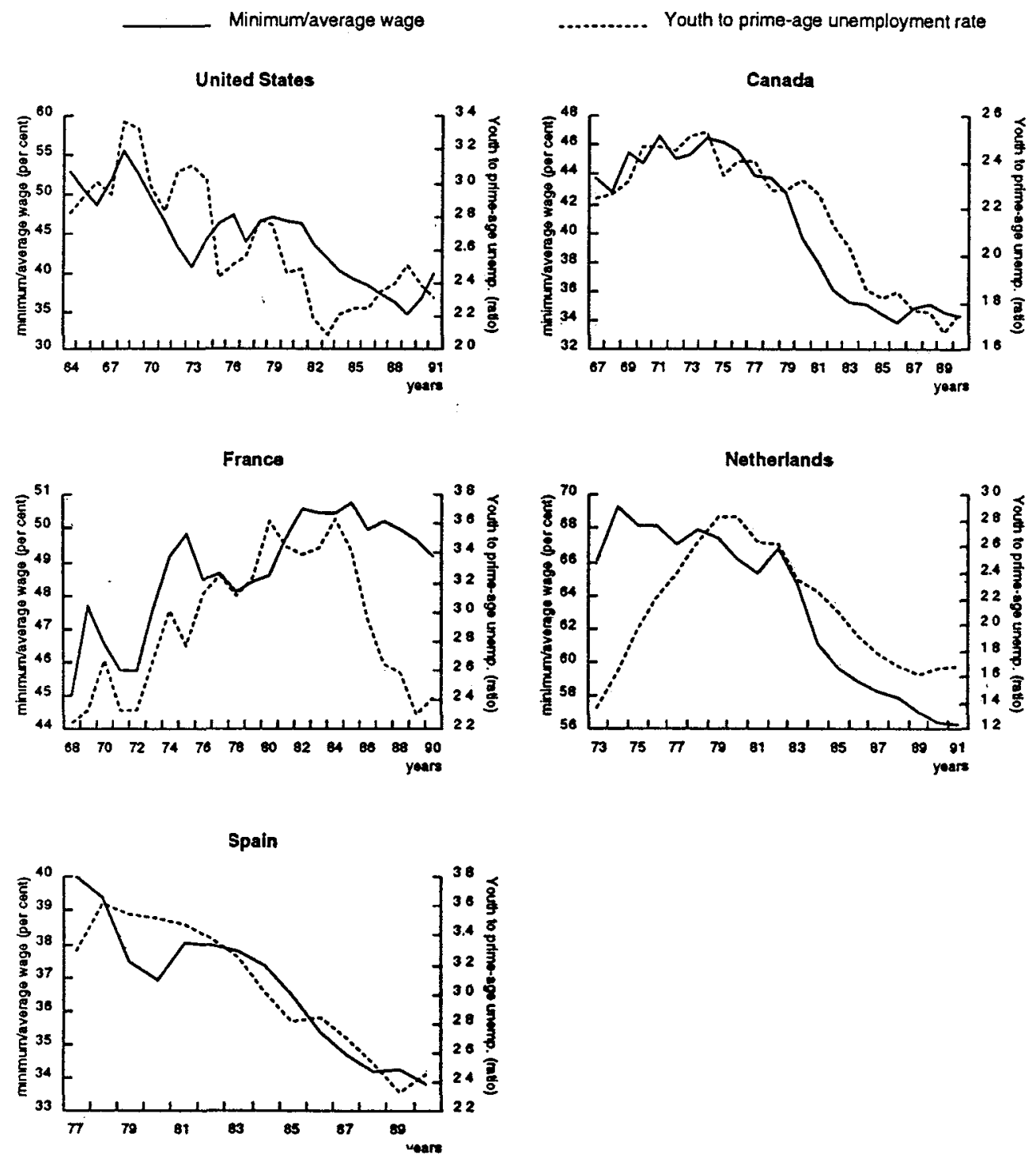

1. Youth is defined as 15 to 24 year of age except for USA and Spain, for which the definition is 16 to 24 . Prime age is defined as 25 to 54 year of age. 


\section{Technical Annex}

\section{Unemployment trends: calculation methods and results}

\subsection{The NAWRU indicator}

The unemployment trends presented in Figure 3 of the main text are based on simple calculations. This section first presents the methods used to compute the indicators, then discusses an alternative derivation of the Okun curves based on actual observations of capacity utilisation, and finally shows the curves in Figure 3 for the countries where the uniform scaling in the text diagram made reading difficult.

The NAWRU indicator is based on a simple linear definition of the NAWRU, as the unemployment rate above (below) which wages accelerate (decelerate):

(1) $\mathrm{D} \log \mathrm{W}=-\mathrm{a} *(\mathrm{U}-\mathrm{NAWRU}), \quad \mathrm{a}>0$

where $\mathrm{W}$ is the nominal wage level, $\mathrm{U}$ is the actual unemployment rate and $\mathrm{D}$ is the first-difference operator. If the parameter a were known, the NAWRU could be constructed based on observed data for the rate of wage inflation and the unemployment rate. The idea in the construction of the NAWRU indicator is that, using (1), an estimate of a can be generated on the basis of consecutive observations of unemployment and wage inflation, under the assumption that the NAWRU is constant between two consecutive periods:

(2) $a=-D^{2} \log W / D U$

Combining (1) and (2), an estimate of the NAWRU in any time period can be calculated as:

(3) $N A W R U=U-\left(D U / D^{2} \log W\right) * D \log W$

Using (3) directly to derive a time series for the NAWRU generally gives reasonable results, but the series contain some stochastic variation and, in the case of some countries, there are occasional large outliers ${ }^{t}$. To overcome these two problems, the outlying observations have been substituted by linear interpolation of the observations around them and the corrected series have been smoothed using the Hodrick-Prescott filter with a smoothing factor of $25^{2}$. In order to avoid end-point problems for the smoothing procedure, the calculations of the NAWRU were extended up to 1993, using the projections of wage inflation and unemployment contained in OECD Economic Outlook 51 (published in July, 1992).

For a few countries, some experimentation has been done with other inflation series and with introducing a lag structure in (1). The impression from these calculations is that the estimates of the trend NAWRU remain relatively unchanged but that both the number of outliers and general stochastic variation increase compared with the indicators used in Figure 3.

Experiments have also been carried out with a one-step procedure for filtering the unemployment rate, while taking into account the information contained in the series on wage inflation. The bivariate Laxton-Tetlow filter was applied, essentially filtering a series which is a weighted average of actual unemployment and an auxiliary series representing the NAWRU estimate based on wage inflation ${ }^{3}$. For the latter, series based on (3) as well as on (1) with different values of the a coefficient were used. In addition, different weights were explored. On the whole, the trends based on this procedure were similar 
to the trends shown in Figure 3 and the problem of aberrant observations when using (3) to generate the auxiliary NAWRU series remained present.

\subsection{The Beveridge-curve indicator}

In the case of the Beveridge-curve indicator, the method was altered slightly to take into account the prior that cyclical fluctuations are associated with a non-linear relationship between the vacancy rate and the unemployment rate. Changing trend unemployment may be interpreted as shifts in the b parameter of the following equation, while the curvature parameter $\mathrm{c}$ is assumed to be constant over time:

(4) $\mathrm{U}=\mathrm{b} * \mathrm{~V}^{-\mathrm{c}} \quad, \quad \mathrm{b}, \mathrm{c}>0$

Between consecutive years, trend unemployment is unlikely to change much and, assuming b constant, the c parameter can be calculated as:

(5) $c=-D \log U / D \log V$

The calculated series for the curvature parameter $c$ generally shows strong stochastic variation and occasional large outliers, when the vacancy rate is almost unchanged between consecutive years. In consequence, it was decided to use the median value of the calculated parameter in the derivation of the b parameter:

(6) $b=U^{*} V^{\text {med(-DIogUDlog } V)}$

Filtering $b$ with the Hodrick-Prescott filter to obtain a smooth series, the trend unemployment rate has subsequently been calculated bv inserting the smoothed $b$, the median $c$ and the average vacancy rate in (4).

As indicated by Figure 3, vacancy rates have not been used directly.' For the United States and Canada, vacancy data are not available and instead an index of job-offer advertisements in newspapers is used. This implies that trends over time may be adequately described by the available series but the levels cannot be interpreted. For this reason, and because the coverage of vacancy data differs from country to country, rendering cross-country comparisons less meaningful, it was decided to use the index of vacancy rates in Figure 3. A general warning may also be appropriate concerning the quality of vacancy data. As noted, their coverage differs across countries; but also within countries coverage may change over time. A prime example of this is Germany, where over the period 1970-85 the market share of total vacancies covered by official vacancy data fell from around 45 per cent to under 25 per cent. Franz(1991) presents evidence on "corrected" vacancy data that suggests a development in trend unemployment derived from the Beveridge curve which is closer to the trend measure based on the NAWRU indicator, in contrast to the trend presented in Figure 3. Another example is Finland, where the Employment Act of 1988 obliged employers to notify all vacancies at the public employment services, probably contributing to an outward shift of the Beveridge curve. As a final warning, the lack of projections for vacancies implies that the trend unemployment series based on the Beveridge curve is more susceptible to end-point problems than the NAWRU indicator.

\subsection{The Okun-curve indicator}

The Okun-curve indicator in Figure 3 has been constructed using methods identical to those used to construct the NAWRU indicator, substituting capacity utilisation for wage inflation. A main uncertainty in this case concerns the choice of indicator for capacity utilisation. The chosen indicator, the ratio of actual GDP to the phase average trend, has the advantage of being an indicator for the whole economy and of 
being available for all OECD countries. On the other hand, it is an "artificial" indicator (i.e. not based on direct observations).

In order to judge the sensitivity of the measured trend unemployment to using a different capacity measure, Figure Al shows both the Okun-curve indicator from Figure 3 (the left-hand charts) and a similar indicator based on capacity utilisation rates in manufacturing or industry according to survey results (the right-hand charts). The latter series is available only for countries where business surveys contain questions concerning capacity utilisation rates.

The overall impression from the two sets of charts is that they provide broadly the same picture. In certain cases, most visibly the United States, Canada and Spain, the charts based on the observed utilisation rates seem, however, to suggest less of a shift in the unemployment rate associated with normal capacity utilisation than the charts based on the "artificial" indicator. It is not clear to what extent this can be related to the more narrow sectoral coverage and to what extent it represents a real phenomenon, i.e. that the results based on the "artificial" capacity utilisation overestimate the upward shift of trend unemployment.

\subsection{Supplementary graphs}

In Figure 3 the various trend indicators were drawn to the same scale for most countries, in order to facilitate cross-country comparison of past experience. However, for countries where the unemployment rate has remained relatively low, this made some of the observations difficult to distinguish. Figure A2 show the same data with a different scaling for Japan, Austria, Iceland, Norway, Sweden and Switzerland.

\section{Cohort effects on age- and gender-specific unemployment rates}

Relative unemployment rates for different cohorts are shown in Figure 7 of the main text, suggesting that cohorts differ systematically with respect to unemployment risk. The figure, however, concerns only three countries and does not permit any conclusions as to whether the cohort effects reflect differences in the attributes of various cohorts or whether they reflect long-run effects of the degree of success or failure upon labour-market entry. A more systematic exploration of these issues, using simple regressions, is presented in Tables A1 and A2.

The regressions presented in Table Al illustrate the same points as Figure 7 but for more countries and disaggregated by gender. They are the result of estimating the following two equations:

$$
\begin{aligned}
& \text { UR25-29(t,g) }=c_{0}+c_{1} * \text { URTOT }(t, g)+c_{2} * \text { UR20-24(t-5,g) } \\
& \text { UR30-34(t,g) }=c_{0}+c_{1} * \text { URTOT }(t, g)+c_{2} * \text { UR20-24(t-10,g) }
\end{aligned}
$$

where the variables denote unemployment rates for the age groups indicated, $t$ is an index of time and $\mathrm{g}$ represents gender or total of the age group in question. Loosely speaking, the equation tests for the existence of effects on age-specific unemployment rates not only from total unemployment rates but also from the unemployment rate which the age group in question experienced at or shortly after entry into the labour market, which is taken to correspond to the age of 20-24 years. The choice of age brackets in (7) and (8) has been constrained by data availability ${ }^{4}$.

Problems of data availability also constrain the number of countries that can be covered, and breaks in the data series reduce estimation periods but, nevertheless, the results are relatively significant. In many cases, the unemployment rate upon entry to the labour market has a significant effect on subsequent 
age-specific unemployment rates. Of the $48 \mathrm{c}_{2}$ coefficients estimated, 21 are significantly positive, while 17 are positive but not significantly so. Only one coefficient, for 25-29 year olds in Finiand, comes out significantly with the wrong sign. Judged by the $c_{1}$ coefficient, the age group between 25 and 29 years experiences more than proportional variations in their unemployment rate, when the aggregate (including aggregate gender-specific) unemployment rate changes, with the estimates for France and Japanese males as the only exceptions. With Germany and Japanese and Swedish women as the exceptions, the opposite is the case for the age group between 30 and 34 .

The results reported in Table A1 strongly suggest the existence of cohort effects but give no indication of whether such effects are caused by attributes of the cohort, such as e.g. differences in education, or by differences in the degree of success upon labour-market entry, related e.g. to so-called scarring effects. To distinguish between the two causal mechanisms, equations (7) and (8) have been estimated with the lagged unemployment rate of the cohort being substituted by a lagged aggregate unemployment rate as the indicator of conditions on the labour market when the cohort in question entered. To the extent that the entry of a new cohort, with potentially different attributes from previous cohorts, is insufficient to materially affect the aggregate unemployment rate, any significant effect from lagged aggregate unemployment is likely to represent persistent effects of the success of entry.

Unlike in the case of lagged cohort-specific unemployment rates, where the lags were given by available age-groupings, it is not clear how much the aggregate (including aggregate gender-specific) unemployment rate should be lagged. Indeed, with labour-market entry occurring at different ages in different countries and also changing over time, there is considerable uncertainty associated with the choice of lag structure.

Two different approaches have been followed for choosing an appropriate lag of the aggregate unemployment rate and the results of both are reported in Table A2. In the first, it has been assumed that a fifth of each cohort enter each year between their 18th and 22nd year. This gives rise to a lag distribution of past aggregate unemployment rates which is relevant for each of the 5-year age groups for which observed unemployment rates are available. Since some of the lags involved in this specification are quite long, it has only been estimated for the age group between 25 and 29 years. The other approach just lags the aggregate unemployment rate corresponding to the centre of the lag distribution in the first approach, which implies respectively a lag of 7 and 12 years for the age groups 25-29 and 30-34. In favour of this approach may be said, that it is not necessarily just unemployment in the year of entry that is relevant for future unemployment but unemployment rates during the first years of the labour-market career's.

The results are less uniform than in the case of a lagged cohort-specific unemployment rates. For the first approach, i.e. the weighted lag structure of past aggregate unemployment rates, out of 21 coefficient estimates 9 are positive and significant. Not less than 5 are significant with the "wrong" sign. At best, these results would seem to support the hypothesis of persistent effects of early unemployment in the cases of United States, Spain, Sweden and (weakly) Portugal but to reject the hypothesis in the case of Japan and (resoundingly so) Germany. This may, of course, be a consequence of the highly stylistic assumptions behind the chosen lag structure.

In the estimations with the simple lag of aggregate unemployment rates, the hypothesis of permanent effects again receives support for the United States, Spain, Sweden and (weakly) Portugal but in this case also for Germany. For both Japan and Finland, the results go both ways but the negative findings tend to be the most significant. In sum, the finding of cohort effects in Table A1 strongly suggests that the patterns shown in Figure 7 are common across countries. The somewhat weaker findings in Table A2 suggest that the cohort effects in some cases may represent persistent effects of early unemployment, but that this may not be the whole explanation, with cohort-specific attributes potentially also playing a role. 


\section{Indicators of regional and sectoral employment change}

Indicators of regional and sectoral employment change are shown in Figure 8 of the main text and in Table 10 some of these indicators are used to illustrate that frictional unemployment may result in higher overall unemployment. The construction of the indicators is not straightforward and is therefore described below. In addition, some further regression results are presented to illustrate the potential role of labour-market friction in explaining total unemployment.

The indicators of sectoral employment change are based on the ISDB data base (Meyer-zu-Schlochtern, 1988 ) while the regional indicators are based on material collected for the preparation of OECD (1989) and OECD (1990). The two indicators, shake-out and turbulence, constructed for both the regional and sectoral dimension of employment change are, respectively, the decline in employment in sectors (regions) with falling employment relative to employment in the previous year and the weighted standard deviation of sectoral (regional) growth rates of employment. For all countries, the maximum number of sectors (regions) and the maximum number of observations have been used. The degree of disaggregation and the observation period therefore differ across countries. The level of regional disaggregation can be gauged from the number of regions as presented in Tables 4 and 5 of the main text, while the level of sectoral disaggregation varies between 25 sectors in Denmark and the Netherlands and 18 sectors in Japan and Norway.

In both the regional and sectoral dimension, the two indicators are heavily influenced by cyclical developments. Indeed, failure to control for such influences was the main criticism against the results reported in Lilien (1982), who purported to illustrate the influences going in the opposite direction, i.e. from sectoral employment shifts and associated friction to aggregate unemployment. Cyclical adjustment is not simple, however, if the hypothesis under examination concerns the influence of employment shifts on the aggregate economy, while seeking to eliminate the influence of aggregate economic fluctuations on employment shifts. Different approaches have been followed in the literature, including the use of money growth rates as an indicator for fluctuations originating at the aggregate level (Samson, 1990). Data constraints and the desirability of a common procedure across countries prevent more elaborate approaches in the current case. The simple procedure used here relies on changes in aggregate wage and price inflation as indicators of aggregate cyclical variations. This is clearly a questionable procedure when accommodated supply shocks lead to both sectoral and regional employment change and changes in the general rate of inflation.

For each of the two indicators and the two dimensions, equation (9) has been estimated:

(9) $\mathrm{I}=\mathrm{c}_{0}+\mathrm{c}_{1}{ }^{*} \mathrm{D} \log \mathrm{PCP}+\mathrm{c}_{2} * \mathrm{D} \log \mathrm{PCP}(+1)+\mathrm{c}_{3} * \mathrm{D} \log \mathrm{W}+\mathrm{c}_{4} * \mathrm{D} \log \mathrm{W}(+1)+$ res

I is the indicator of employment change for the dimension in question, PCP is the private consumption deflator and $\mathrm{W}$ the average business-sector wage. The leads in inflation have been included because aggregate fluctuations of activity could be expected to influence employment shifts directly, but inflation possibly with a lag. The equation residuals, res, represent the variation of employment change that is unrelated to aggregate inflation. To generate indicators of autonomous, structural employment change, the residuals have been substituted back into the estimated equation (9) with all other variables replaced by sample means. These indicators have subsequently been smoothed, using the Hodrick-Prescott filter, and the resulting main trends plotted in Figure 8.

The equation residuals from (9) have been used directly as independent variables in the equations for the impact of friction on overall unemployment:

$$
\mathrm{DU}=\mathrm{c}_{0}+\mathrm{c}_{1}{ }^{*} \text { res }+\mathrm{c}_{2}{ }^{*} \text { Lres }+\mathrm{c}_{3}{ }^{*} \mathrm{LU}
$$


where $\mathrm{L}$ is a lag operator. The results of this estimation are shown in Table 10 of the main text in the cases of the sectoral and regional shake-out indicators. Table A3 shows the corresponding results in the case of the turbulence indicators. The equation has also been estimated with added time trends, but since this does not seem to materially affect the $c_{1}$ and $c_{2}$ coefficients, the results are not reported.

The results using the turbulence indicator are generally very weak (Table A3). This conforms relatively well with the findings in the literature, which has focused almost exclusively on the turbulence indicator, and where results have typically been weak once data have been cyclically adjusted. With the available information, it is only possible to speculate about the possible causes for the different results with the shake-out and turbulence indicators. To the extent they are not an artificial product of the procedure for cyclical adjustment, the differences suggest that dispersion of employment growth rates may have larger impacts on total unemployment when absolute falls in sectoral or regional employment are involved. One reason may be that job shifts are more likely to involve an intermediate period of unemployment when they occur against the background of sectoral or regional employment contraction than if they take place between growing sectors. Another may be that mobility out of sectors and regions differ and is particularly low for the sectors and regions which typically contract from time to time.

\section{Causality between public and private sector wages}

The relationship between aggregate private sector and public sector wages is discussed in Section 3.3.6.1 of the main text. The empirical results underlying the conclusions presented in that section is given in Tables A4 and A5. The issue is to which extent it is possible to find a systeriatic relationship between public and private sector wages, with one sector tending to lead the other in terms of aggregate wages. Evidently, it is difficult to interpret time series for average wages in this way, and the method used here is relatively mechanistic. Moreover, it should be underlined that "leading" relationships at the aggregate level do not necessarily imply that the directions of the "lead" are the same for individual groups.

The data series used have been derived from annual national accounts and in both the case of the public and the private sector, the series is an implicit average wage rate, defined by dividing the wage sum by the number of employees. Thus, many sources of bias are involved in comparing these series, including possible differences in the development of part-time work in the two sectors. In addition, for some countries some non-wage elements of compensation may be included in the public sector wage sum, further complicating the picture.

These caveats should be kept in mind when interpreting the "causality" tests in Tables A4 and A5. Put simply, the tests presented in Table A4 focus on the medium-term causality links between public and private sector wages. The growth rate of each of the two series is regressed on its own lags and lags of the growth rate of the other series. If the lags of the other series are jointly significant, the other series is regarded as causing the first series. Thus, if the effect of one significant lag is offset by opposite signs on other lags, the medium-term relationship is not regarded as causal. The focus is, in other words, on the effects sustained after the three-year period considered.

Significant results are achieved for 11 out of 20 countries, mostly those for which the data period is relatively long. In all these cases causality is uni-directional. Moreover, with Australia as the sole exception, causality runs from private to public sector wages.

Table A5 shows the results of applying the concept of Granger causality to the same issue and they broadly confirm the conclusion reached above? ${ }^{7}$. Only for Australia, Austria, Belgium and Sweden were one of the lags of government wages significant and correctly signed in the equation for private sector wages. Of these countries, only in the cases of Australia and Belgium were private sector wages jointly 
insignificant in the determination of public sector wages, implying Granger causality. The other way round, i.e. Granger causality running from private to public sector wages, the test was accepted in the cases of United States, Japan, Germany, France, Italy, Canada, Austria, Denmark, Finland, Norway and Switzerland.

\section{Estimations of employment behaviour}

The adjustment of employment to changes in output and real wages was discussed in Section 3.3.7 of the main text. In order to illustrate the differences in adjustment speeds across countries, simple employment equations have been estimated and the main results are shown in Table A6. The estimated equations, with employment growth as the dependent variable (cf. bottom of Table A6), have been specified with an error-correction mechanism, based on profit-maximising behaviour and an underlying aggregate CES production technology. Constant returns to scale are assumed, implying that the long-run employment elasticity with respect to output is unity. Time trends are entered as proxies for labour-augmenting technical progress. The estimations are based on annual data, with the sample periods varying across countries depending on data availability.

Generally, the short-term employment response to changes in output is strongly significant, the only exceptions being Greece, Iceland and Portugal. More than half of the long-term employment response to output occurs within the first year in North America, Belgium, Denmark, Finland, Spain and Switzerland while the adjustment seems to be particularly slow in Japan, Italy, New Zealand and Sweden. The relative adjustment speeds generally conform well with the impression based on the indicator of employment responsiveness given in Table 7 of the main text.

The response to changes in real wages is much less well determined. The long-run response in the form of the elasticity of substitution can be determined from significant coefficient estimates in only eight countries. For two of these, Iceland and Netherlands, the short-term response was insignificant. The estimates found for elasticities of substitution may generally appear relatively low, which should be taken into account in assessing the share of long-term adjustment occurring within the first year. Nevertheless, they mostly fall within the range used for the construction of Figure 6 in the main text. 


\section{Notes}

1. This is typically the result of wage inflation remaining almost unchanged between two years, implying a denominator of (3) close to zero.

2. The observations that have been substituted by interpolation are: Japan (1990), Germany $(1967,1969)$, Italy (1965), United Kingdom (1992), Canada (1977), Australia (1976, 1982, 1989), Austria (1974), Denmark (1974, 1978, 1984), Finland (1988-93), Netherlands (1981), New Zealand (1975), Norway (1988-89), Sweden (1968, 1970, 1975), Switzerland (1975-76, 1991).

3. For a presentation of this filter, see Laxton and Tetlow (1992).

4. The unemployment rates of the age groups between 25 and 29 years and 30 and 34 years may, of course, affect the total unemployment rate. While this may bias the results for the $c_{1}$ coefficient, it should be noted that the age groups in question are a relatively small fraction of the total labour force and that some substitution would be expected to take place between cohorts.

5. Under the assumptions stated in the text, a fifth of this five-year age group entered the labour market seven years earlier, 16 per cent entered both 8 and 6 years earlier, 12 per cent both 9 and 5 years earlier, 8 per cent both 10 and 4 years earlier and 4 per cent both 11 and 3 years earlier.

6. A trade-off is involved in choosing the lag. For example, a lag of seven years is too long to represent relevant entry experience for those 25-year olds who entered the labour market later than their 18 th year. On the other hand, some of the 29 -year olds who entered the labour market very early may already have been positively or negatively "scarred" before becoming 22 .

7. One series is said to Granger-cause another if just one lag of the series enters significantly in the determination of the other series while all the lags of the other series are jointly insignificant in the determination of the first series.

8. Formally, government wages also Granger cause private wages in the United Kingdom, but the sign of the effect from government wages on private wages is perverse. 
Table Al. Cohort effects using lagged cohort unemployment

\begin{tabular}{|c|c|c|c|c|c|c|c|c|}
\hline Country & $\begin{array}{c}\text { Dependent } \\
\text { unemployment rate }\end{array}$ & Constant & $\begin{array}{l}\text { Total current } \\
\text { unemployment } \\
\text { rate of gender } \\
\text { or total }\end{array}$ & $\begin{array}{l}\text { 5-year lagged } \\
\text { unemployment } \\
\text { rate of cohort } \\
\text { and geader }\end{array}$ & $\begin{array}{l}\text { 10-year lagged } \\
\text { unemployment } \\
\text { rate of cohort }\end{array}$ & $\mathrm{R}^{2}$ & DW & $\begin{array}{l}\text { Estimation } \\
\text { period }\end{array}$ \\
\hline \multirow[t]{6}{*}{ United States } & Male, $25-29$ years & $-1.69 * * *$ & $1.27 * * *$ & $0.03 *$ & .. & 0.99 & 155 & $1960-91$ \\
\hline & Female, $25-29$ years & -0.35 & $1.06 * * *$ & 0.03 &.. & 0.94 & 142 & $1960-91$ \\
\hline & Total, $25-29$ years & $-1.70 * * *$ & $1.22 * * *$ & $0.06 * * *$ & .. & 099 & 1.33 & $1960-91$ \\
\hline & Male, $30-34$ years & $-107^{* *}$ & $0.92^{* * *}$ & .. & $0.04 * *$ & 0.99 & (1) & $1960-91$ \\
\hline & Female, $30-34$ years & $1.04^{* *}$ & $0.80 * * *$ & .. & -0.03 & 090 & 1.57 & $1960-91$ \\
\hline & Total, 30.34 years & $-0.87 * *$ & $0.93^{* * *}$ & .. & 0.03 & 0.99 & (1) & $1960-91$ \\
\hline \multirow[t]{6}{*}{ Japan } & Male, $25-29$ years & 0.12 & $089 * * *$ & 0.03 &.. & 0.96 & (1) & $1975-86$ \\
\hline & Female, $25-29$ years & -0.10 & $1.56^{* * *}$ & 008 & .. & 0.96 & 1.37 & $1968-91$ \\
\hline & Total, $25-29$ years & 006 & $1.02 * * *$ & $0.11 * *$ &.. & 0.98 & (1) & $1968-91$ \\
\hline & Male, $30-34$ years & -0.19 & $0.82^{* * *}$ & .. & 0.02 & 0.92 & 1.99 & 1972.91 \\
\hline & Female, $30-34$ years & 0.09 & $1.10^{* * *}$ & .. & 0.01 & 0.87 & 1.55 & $1972-91$ \\
\hline & Total, 30.34 years & -0.17 & $0.95 * * *$ & .. & 0.01 & 0.96 & 1.94 & $1972-91$ \\
\hline \multirow[t]{6}{*}{ Germany } & Male, 25-29 years & $-4.15^{* * *}$ & $1.46 * * *$ & $0.09 *$ & .. & 1.00 & (1) & $1975-86$ \\
\hline & Female, $25-29$ years & 0.94 & $1.23 * * *$ & -0.06 & .. & 0.93 & 0.94 & $1975-86$ \\
\hline & Total, $25-29$ years & -453 & $1.46^{* * *}$ & 0.05 & .. & 0.99 & (1) & $1975-86$ \\
\hline & Male, $30-34$ years & $-0.45 * * *$ & $1.03 * * *$ & .. & $0.02 * *$ & 1.00 & 2.44 & $1980-86$ \\
\hline & Female, 30-34 years & -0.02 & $1.03^{* * * *}$ & .. & $0.17^{* * *}$ & 100 & 2.22 & $1980-86$ \\
\hline & Total, $30-34$ years & $-0.36^{* *}$ & $1.04^{* * *}$ &. & $0.08 * *$ & 1.00 & 2.34 & $1980-86$ \\
\hline \multirow[t]{6}{*}{ France } & Male, 25-29 years & $-0.87 * *$ & $0.98 * * *$ & $0.25 * *$ & .. & 098 & 2.16 & $1973-81$ \\
\hline & Female, $25-29$ years & 0.55 & $0.76 * * *$ & 0.12 . & .. & 0.96 & 1.42 & $1973-81$ \\
\hline & Total, $25-29$ years & .0 .24 & $0.80 * * *$ & $0.23 * *$ & .. & 0.99 & 117 & $1973-81$ \\
\hline & Male, $30-34$ years & -4.25 & 043 & .. & 2.40 & 0.99 & 2.22 & 1978-81 \\
\hline & Female, $30-34$ years & 2.59 & 026 & .. & 0.57 & 0.96 & 3.22 & $1973-81$ \\
\hline & Total, $30-34$ years & -0.15 & $0.39 * *$ & .. & $0.80^{* *}$ & 1.00 & 3.15 & $1978-81$ \\
\hline \multirow[t]{6}{*}{ Finland } & Maie, $25-29$ years & $-1.45^{*}$ & $1.40^{* * *}$ & -0.06 & .. & 0.97 & (1) & $\lfloor 975-9 \mid$ \\
\hline & Female, $25-29$ years & -0.29 & $106 * * *$ & -0.00 & .. & 0.90 & 1.95 & $1975-91$ \\
\hline & Total, $25-29$ years & -031 & $1.31^{* * *}$ & $-0.14 * * *$ &.. & 097 & 1.41 & 1975.91 \\
\hline & Maie, 30.34 years & -0.17 & $0.92 * * *$ & .. & -0.02 & 0.98 & 2.78 & $1980-91$ \\
\hline & Fomale, $30-34$ years & -0.35 & $082 * * *$ & .. & $015^{* *}$ & 077 & 166 & $1980-91$ \\
\hline & Total. $30-34$ years & $.067 *$ & $0.92^{* * *}$ & .. & $0.05^{*}$ & 096 & 1.20 & $1980-91$ \\
\hline \multirow[t]{6}{*}{ Portugal } & Male, $25-29$ years & 1.39 & $110 * * *$ & -0.10 & .. & 083 & 1.78 & $1979-91$ \\
\hline & Female, $25-29$ years & -2.84 & $1.03 * * *$ & $0.24^{* *}$ & .* & 0.63 & 1.54 & $1979-91$ \\
\hline & Total, $25-29$ years & -1.44 & $1.23^{* * *}$ & 0.12 & .. & 0.66 & 1.39 & 1979.91 \\
\hline & Male, $30-34$ years & 0.03 & $0.67 * * *$ &.. & 0.05 & 096 & 359 & $1984-91$ \\
\hline & Femaie, $30-34$ years & 2.94 & $0.60^{* *}$ & .. & -0.00 & 0.94 & 3.46 & $1984-91$ \\
\hline & Total, $30-34$ years & $1.17 * *$ & $0,68^{* * * *}$ & .. & 0.02 & 0.99 & 258 & $1979-91$ \\
\hline \multirow[t]{6}{*}{ Spain } & Male, $25-29$ years & -0.50 & $1.25 * * *$ & $0.04 * * *$ & .. & 0.99 & 2.66 & $1977-91$ \\
\hline & Female, $25-29$ years & -2.05 & $1.14^{* * *}$ & $0.10 * * *$ & .. & 0.99 & 1.72 & $1977-91$ \\
\hline & Total, $25-29$ years & $-1.04 * *$ & $1.22 * * *$ & $0.08 * * *$ & .. & 1.00 & 2.30 & 1977.91 \\
\hline & Male, 30-34 years & .0 .05 & $0.80 * *$ & .. & 0.02 & 0.98 & 1.33 & $1982-91$ \\
\hline & Female, 30-34 years & $-10.00 * * *$ & $0.99 * * *$ & .. & $0.35 * * *$ & 0.98 & 1.53 & $1982-91$ \\
\hline & Total, $30-34$ years & -0.77 & $0.47^{* * *}$ & .. & $0.17 * * *$ & 0.98 & 1.55 & $1982-91$ \\
\hline \multirow[t]{6}{*}{ Sweden } & Male, 25-29 years & 0.49 & $1.14^{* * * *}$ & 0.01 & .. & 0.97 & (1) & $1968-86$ \\
\hline & Female, 25.29 years & $-0.66 * *$ & $1.14^{* * * *}$ & $0.14 * *$ & .. & 092 & 148 & $1968-86$ \\
\hline & Total, $25-29$ years & -0.37 & $1.10^{* * * *}$ & $0.12 * *$ & .. & 0.98 & (1) & 1968.86 \\
\hline & Male, $30-34$ years & $-0.41^{* * * *}$ & $0.86^{* * *}$ & .. & 0.05 & 0.97 & 2.33 & $1973-86$ \\
\hline & Female, $30-34$ years & $-0.54^{*}$ & $1.01 * * *$ & ..: & -0.01 & 0.88 & 1.41 & $1973-86$ \\
\hline & Total: $30-34$ years & $-0.46 * * *$ & $0.98 * * *$ & .. & -0.02 & 0.96 & 2.38 & $1973-86$ \\
\hline
\end{tabular}

1.

Estimated using Cochran-Orcutt adjustment for first-order autoconelation. 
Table A2. Cohort effects using lagged aggregate unemployment

\begin{tabular}{|c|c|c|c|c|c|c|c|c|c|}
\hline Conatry & $\begin{array}{l}\text { Dependent } \\
\text { unemployment } \\
\text { rate }\end{array}$ & Coostant & $\begin{array}{l}\text { Toual current } \\
\text { unemployment } \\
\text { rate of gender } \\
\text { or cotal }\end{array}$ & $\begin{array}{l}\text { Weighted average } \\
\text { of lagged unemployment } \\
\text { rates of gender } \\
\text { of total }\end{array}$ & $\begin{array}{l}\text { 7-year lagged } \\
\text { unemployment } \\
\text { rates of gender } \\
\text { or total }\end{array}$ & $\begin{array}{l}\text { 12-year lagged } \\
\text { unemployment } \\
\text { rates of gendet } \\
\text { or tolal }\end{array}$ & $\mathbf{R 2}$ & DW & $\begin{array}{l}\text { Estimation } \\
\text { period }\end{array}$ \\
\hline \multirow[t]{9}{*}{ United States } & Male, 25-29 years & $-186^{=m}$ & $129=$ & 005 & & & 098 & 161 & 1971.91 \\
\hline & Female. 25-29 years & $-113^{* *}$ & $100==$ & $019 * *=$ & & & 098 & 235 & $1971-91$ \\
\hline & Total, $25-29$ years & $-198=*$ & $121=$ & $015=\cdots$ & & & 099 & 188 & $1971-91$ \\
\hline & Make, 25-29 years & $-175^{*+\infty}$ & $127 * \ldots$ & & $006^{* *}$ & & 099 & 169 & $1967-91$ \\
\hline & Female, $25-29$ years & $.073^{\prime \prime}$ & $104=*=$ & & $011==*$ & . & 097 & 233 & $1967-91$ \\
\hline & Total, $25-29$ years & $-184^{* * *}$ & $122^{* * *}$ & & $011=0$ & & 099 & 207 & $1967-91$ \\
\hline & Male, 30-34 years & .029 & $091^{* * *}$ & & & 006 & 098 & (1) & 1972.91 \\
\hline & Female, $30-34$ years & -107 & $092 * 1 *$ & . & & $015 *$ & 094 & 214 & $1972-91$ \\
\hline & Total, 30-34 years & 003 & $094 * *=$ & & & 003 & 099 & (l) & $1972-91$ \\
\hline \multirow[t]{9}{*}{ Japan } & Male, 25-29 years & $126=0$ & $060^{* * *}$ & $-019=$ & . & & 084 & 200 & $1979-91$ \\
\hline & Female, 25-29 years & 066 & $126 * * *$ & 016 & & & 076 & 126 & $1979-91$ \\
\hline & Total, 25-29 years & $095=-=$ & $077^{* * *}$ & 006 & & . & 089 & 178 & 1979.91 \\
\hline & Male, $25-29$ years & $107 * * *$ & $062^{*=*}$ & & $-011=$ & & 081 & 208 & $1975-91$ \\
\hline & Fernale, $25-29$ years & 028 & $141=*$ & ; & 016 & & 087 & 126 & $1975-91$ \\
\hline & Total, 25.29 years & $070^{* * * *}$ & $084 * * *$ & . & $010^{*}$ & & 091 & 153 & $1975-91$ \\
\hline & Male, $30-34$ years & 036 & $072 * * *$ & & & .013 & 085 & 254 & $1980-91$ \\
\hline & Female, $30-34$ years & 084 & $082 * 0$ & : & & .004 & 070 & 243 & $1980-91$ \\
\hline & Tonal, 30-34 years & $050^{\circ}$ & $076=* *$ & . & & $-010^{\circ}$ & 092 & 264 & $1980-91$ \\
\hline \multirow[t]{9}{*}{ Germany } & Male, 25-29 years & $191^{\circ}$ & $149 * * *$ & $-135=*$ & & & 099 & 201 & $1981-86$ \\
\hline & Female, 25-29 years & 0.54 & $232 * * *$ & $-2.13^{* 0}$ & & & 095 & 303 & $1981+86$ \\
\hline & Total, $25-29$ years & $196^{*}$ & $179=0$ & $-173 * *$ & & . & 099 & 320 & $198 \mid-86$ \\
\hline & Make. 25.29 yeats & 006 & $100= \pm$ & & $042 \div=$ & . & 099 & 131 & $1977-86$ \\
\hline & Female. 25-29 years & 176 & $094=$ & & 027 & & 092 & 108 & 1977.86 \\
\hline & Total. 25.29 years & 083 & $094= \pm=$ & . & 042 & . & 097 & 107 & 1977.86 \\
\hline & Nale, $30-34$ years & -073 & $107^{* * *}$ & & . & $009=$ & 100 & 229 & $1982-80$ \\
\hline & Female, $30-34$ years & .012 & $103 \cdots$ & . & . & $056 *$ & 099 & 241 & $1982-86$ \\
\hline & Total, 30-34 years & .071 & $108= \pm$ & . & : & $030^{=1}$ & 100 & 243 & $1982-86$ \\
\hline \multirow[t]{3}{*}{ France } & Make. 25-29 years & 072 & I $51 *$ & . & -181 & & 0.97 & 174 & $|975-8|$ \\
\hline & Female. $25-29$ years & 113 & $=114^{m+\infty}$ & . & 089 & - & 095 & 200 & 1975-81 \\
\hline & Total, 25-29 years & 025 & $132=$ & · & -103 & & 097 & 170 & $1975-81$ \\
\hline \multirow[t]{9}{*}{ Finland } & Malç. 25-29 years & $136^{\circ}$ & $139 * * *$ & $-065 * * *$ & . & . & 098 & 186 & $|981-9|$ \\
\hline & Fernate, 25-29 years & -144 & $109 * *$ & $023^{*}$ & & $\cdots$ & 092 & 289 & $1981-91$ \\
\hline & Total, $25-29$ years & .058 & $129 * \cdots$ & .017 & - & & 096 & 169 & $1981-91$ \\
\hline & Male. 25-29 years & .030 & $142 *=$ & & $.033^{* * * *}$ & & 096 & 132 & 1977.91 \\
\hline & Female, $25-29$ years & .056 & $100 *$ & . & 006 & & 085 & 207 & 1977.91 \\
\hline & Total, $25-29$ years & .066 & $133^{=0 *}$ & . & $.017 * 0$ & & 096 & 152 & 1977.91 \\
\hline & Make, $30-34$ years & -023 & $092^{20.4}$ & . & - & 000 & 098 & 250 & $1982-91$ \\
\hline & Female, $30-34$ years & .026 & $0.77^{* a}$ &. & . & $016^{\circ}$ & 0.79 & $16 !$ & $1982-91$ \\
\hline & Total, 30-34 years & .059 & $092^{* * *}$ & . & . & 007 & 097 & 096 & $1982-91$ \\
\hline \multirow[t]{9}{*}{ Portugal } & Male, 25-29 years & -101 & 135 wnt & 0.15 & . & .. & 094 & 284 & $1985-91$ \\
\hline & Female, 25-29 years & .170 & $184=0$ & -012 & & $\therefore$ & 096 & (1) & $1985.9 !$ \\
\hline & Total, 25-29 years & $.5503^{* m}$ & $2.50=0=$ & 6630 & .. & . & 098 & (i) & $\mid 985-91$ \\
\hline & Male, $25-29$ years & 026 & $132=0$ & . & .018 & . & 084 & 155 & $1981-91$ \\
\hline & Fernale. 25-29 years & -349 & $130=0$ & . & $035 *$ & . & 081 & 147 & $1981-91$ \\
\hline & Total, $25-29$ years & .035 & $121=\cdots$ & .. & 015 & . & $0 \pi$ & 144 & 1981.91 \\
\hline & Mak. $30-34$ years & .012 & $078^{* *}$ & .. & . & 005 & 095 & 354 & $1986-91$ \\
\hline & Female, $30-34$ years & 873 & 008. & & $\because$ & .022 & 092 & 305 & $1986-91$ \\
\hline & Toal, 30-34 yeart & 194 & $062^{*}$ & .. & . & .003 & -099 & 188 & $|986-9|$ \\
\hline \multirow[t]{9}{*}{ Spain } & Make, 25-29 yearz & -2.16 & $132=$ & 015 & .. & . & 098 & 289 & 1983-91 \\
\hline & Feniale, 25-29 years & -001 & 1.09 "at. & $0.200=0$ & . & . & 096 & 280 & $1983-91$ \\
\hline & Tocal, 25-29 years & -2.05 & $127 * n$ & $019=$ & . & . & 094 & 265 & |983-91 \\
\hline & Make, 25-29 years: & -062 & $127=00$ &. & 009 & . & 099 & 2,53 & 1979.91 \\
\hline & Femake. 25-29 years & -403 & $127^{40+4}$ & .. & $0170=$ & . & 099 & 213 & 1979.91 \\
\hline & Tocal, $25-29$ years & $-187 * *$ & $128=\ldots *$ & . & $016^{* 1 *}$ & . & 099 & 246 & $1979-91$ \\
\hline & Make, 30-34 years & 185 & $072=00$ & .. & .. & -009 & 098 & 132 & 1984-91 \\
\hline & Femake, $30-34$ years & $-1741^{*}$ & $123^{m+\infty}$ & .. & .. & $1.27 * 0$. & 094 & (1) & $1984-91$ \\
\hline & Total, 30-34 years & $591^{\circ *}$ & $044^{* 00}$ & . & * & $026^{* *}$ & 086 & 248 & $1984-91$ \\
\hline \multirow[t]{9}{*}{ Sweden } & Make, $25-29$ years & $-263^{-00}$ & $149 * 0 *$ & $108=$ & - & .. & 098 & 167 & $1974-86$ \\
\hline & Female. 25-29 yeara & $-236^{* *}$ & $1.14 * \omega *$ & $096^{\circ 0}$ & . & . & 0.93 & 157 & 197486 \\
\hline & Total, $25-29$ years & $-2.58=0 *$ & 1.3300. & $105=0$ & . & - & 099 & 2.47 & $1974: 86$ \\
\hline & Make, 25.29 years & $-142 * *$ & $148 \cdots \cdots$ &. & $040=$ & .. & 094 & 144 & $1970-86$ \\
\hline & Female, 25-29 years & .054 & $1.19=0$ & .. & 012 & .. & 089 & 1.70 & $1970-86$ \\
\hline & Tocal, 25-29 year & -10600 & $134=0$ & . & $027 \div$ & - & 095 & 134 & $1970-86$ \\
\hline & Mak, 30-34 years & .026 & $0.92 * *$ & . &.. & .009 & 097 & 225 & $1975-86$ \\
\hline & Femake, $30-34$ years & $.077=0$ & $088=10$ & . & .. & $025-$ & 091 & 125 & $1975-86$ \\
\hline & Total, 30-34 years & $-044=$ & $093=0$ & .. & . & 002 & 097 & 200 & $1975-86$ \\
\hline
\end{tabular}

1 Estimated using Cochnn-Oreutt adjustument for first order antocomelanion. 
Table A3. Impact of friction on unemployment (1)

\begin{tabular}{|c|c|c|c|c|c|c|c|}
\hline \multirow[t]{2}{*}{ Country } & \multirow[t]{2}{*}{ Constant } & \multicolumn{2}{|c|}{$\begin{array}{l}\text { Coefficient on cyclically-adjusted } \\
\text { employment turbulence }\end{array}$} & \multirow{2}{*}{$\begin{array}{c}\text { Coefficient } \\
\text { of lagged } \\
\text { unemployment }\end{array}$} & \multirow[t]{2}{*}{ DW } & \multirow[t]{2}{*}{ R2 } & \multirow[t]{2}{*}{ Estimation period } \\
\hline & & Actual & One period lagged & & & & \\
\hline \multicolumn{8}{|c|}{ Panel A. Impact of sectoral employment turbulence } \\
\hline United States & 0.78 & -5.21 & -1.23 & -0.132 & 1.58 & 0.17 & $1962-88$ \\
\hline Japan & 0.37 & 0.85 & -0.32 & -0.137 & 1.87 & 0.17 & $1972-88$ \\
\hline Germany & 2.41 & 4.76 & -4.51 & $-0.413^{* *}$ & (2) & 0.31 & $1963-88$ \\
\hline France & 1.13 & -8.33 & 1.24 & -0.098 & (2) & 0.31 & $1973-88$ \\
\hline Italy & 0.24 & -0.38 & 0.57 & 0.019 & 1.89 & 0.01 & $1972-88$ \\
\hline United Kingdom & 1.62 & 0.42 & -0.32 & -0.237 & (2) & 0.13 & $1965-88$ \\
\hline Canada & 2.80 & -1.18 & -8.44 & -0.320 & (2) & 0.34 & $1972-87$ \\
\hline Australia & 1.25 & -3.12 & -4.44 & -0.166 & 1.90 & 0.29 & $1972-88$ \\
\hline Belgium & 4.61 & -12.05 & 2.37 & $-0.430^{*}$ & (2) & 0.36 & $1973-88$ \\
\hline Denmark & 1.18 & 3.60 & -2.60 & -0.122 & (2) & 0.24 & $1969-88$ \\
\hline Finland & 3.26 & -9.88 & 0.00 & $-0.680^{* *}$ & 1.77 & 0.53 & $1979-89$ \\
\hline Netherlands & 0.22 & $16.31^{* * *}$ & $18.01^{* * *}$ & 0.053 & (2) & 0.78 & $1973-88$ \\
\hline Sweden & 0.61 & 0.17 & -0.09 & -0.351 & (2) & 0.17 & $1972-88$ \\
\hline Norway & 0.62 & -1.00 & -0.64 & $-0.314^{*}$ & 1.53 & 0.17 & $1965-87$ \\
\hline \multicolumn{8}{|c|}{ Panel B. Impact of regional employment turbulence } \\
\hline United States & 1.22 & 2.07 & 6.48 & -0.201 & 1.59 & 0.15 & $1962-87$ \\
\hline Japan & 0.31 & 0.92 & $1.56^{* *}$ & -0.097 & (2) & 0.63 & $1976-87$ \\
\hline Germany & 0.46 & 1.33 & 0.98 & -0.056 & (2) & 0.05 & 1963-85 \\
\hline France & 0.43 & 43.03 & 12.54 & 0.022 & 1.76 & 0.32 & 1976-87 \\
\hline Italy & -0.17 & 0.32 & 2.08 & 0.068 & 1.93 & 0.07 & $1963-87$ \\
\hline United Kingdom & 1.38 & -2.21 & -1.40 & -0.226 & (2) & 0.13 & $1967-89$ \\
\hline Canada & 1.47 & -0.02 & 0.00 & -0.162 & 1.51 & 0.12 & $1969-87$ \\
\hline Australia & 0.45 & 0.41 & -2.79 & -0.034 & 2.03 & 0.16 & $1968-87$ \\
\hline Austria & 0.59 & -1.04 & -0.58 & -0.158 & (2) & 0.08 & $1973-87$ \\
\hline Finland & 5.47 & $-9.99 * *$ & $6.09^{*}$ & $-1.061^{* * *}$ & (2) & 0.98 & 1979-87 \\
\hline Norway & 1.34 & -3.86 & $12.48^{* *}$ & $-0.494^{*}$ & (2) & 0.58 & $1977-88$ \\
\hline Spain & 4.46 & $-21.46^{* *}$ & -9.84 & $-0.208 * * *$ & 2.06 & 0.83 & $1979-88$ \\
\hline Ṡweden & 0.14 & 1.49 & -4.40 & -0.111 & (2) & 0.36 & $1978-87$ \\
\hline
\end{tabular}

1. Based on estimates of the following equation:

DUR $=a+b^{*} E S+c^{*} E S(-1)+d^{*} U R(-1)$

where DUR is change in unemployment rate, ES is cyclically-adjusted employment turbulence and UR is the unemployment rate.

2. Has been estimated using the Coctrane-Orcutt method to deal with first-order autocorrelation. 
Table A4. Causality between public and private sector wages

\begin{tabular}{|c|c|c|c|}
\hline \multicolumn{4}{|c|}{ 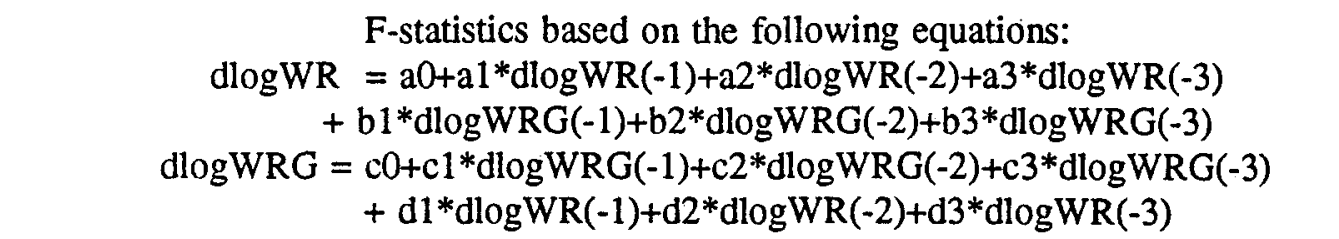 } \\
\hline & Period & H0: $\operatorname{sum}(b)=0$ & H0: $\operatorname{sum}(d)=0$ \\
\hline United States & $1967-89$ & 0.01 & $5.90 * *$ \\
\hline Japan & $1969-89$ & 0.50 & $3.68 *$ \\
\hline Germany & $1967-89$ & 0.76 & 0.00 \\
\hline France & $1974-89$ & 0.18 & 0.42 \\
\hline Italy & $1967-89$ & 0.34 & $5.74 * *$ \\
\hline United Kingdom & $1967-89$ & 0.50 & $4.03 *$ \\
\hline Canada & $1970-89$ & 0.54 & 0.10 \\
\hline Australia & $1968-89$ & $21.70^{* * *}$ & 0.59 \\
\hline Austria & $1974-89$ & 0.07 & 1.47 \\
\hline Belgium & $1974-89$ & 2.00 & 0.04 \\
\hline Denmark & $1970-89$ & 1.56 & $8.85^{* *}$ \\
\hline Finland & $1967-89$ & 1.55 & $8.40^{* * *}$ \\
\hline Netherlands & $1974-89$ & 0.81 & 0.00 \\
\hline New Zealand & $1969-89$ & 1.68 & 0.00 \\
\hline Norway & $1967-89$ & 0.01 & $6.32 * *$ \\
\hline Portugal & $1967-89$ & 0.36 & $3.84^{*}$ \\
\hline Spain & $1968-89$ & 0.30 & $12.45 * * *$ \\
\hline Sweden & $1967-89$ & 0.74 & 2.12 \\
\hline Switzerland & $1967-89$ & 0.84 & $8.64 * * *$ \\
\hline
\end{tabular}

* Rejected at 10 per cent level.

** Rejected at 5 per cent level.

*** Rejected at 1 per cent level. 


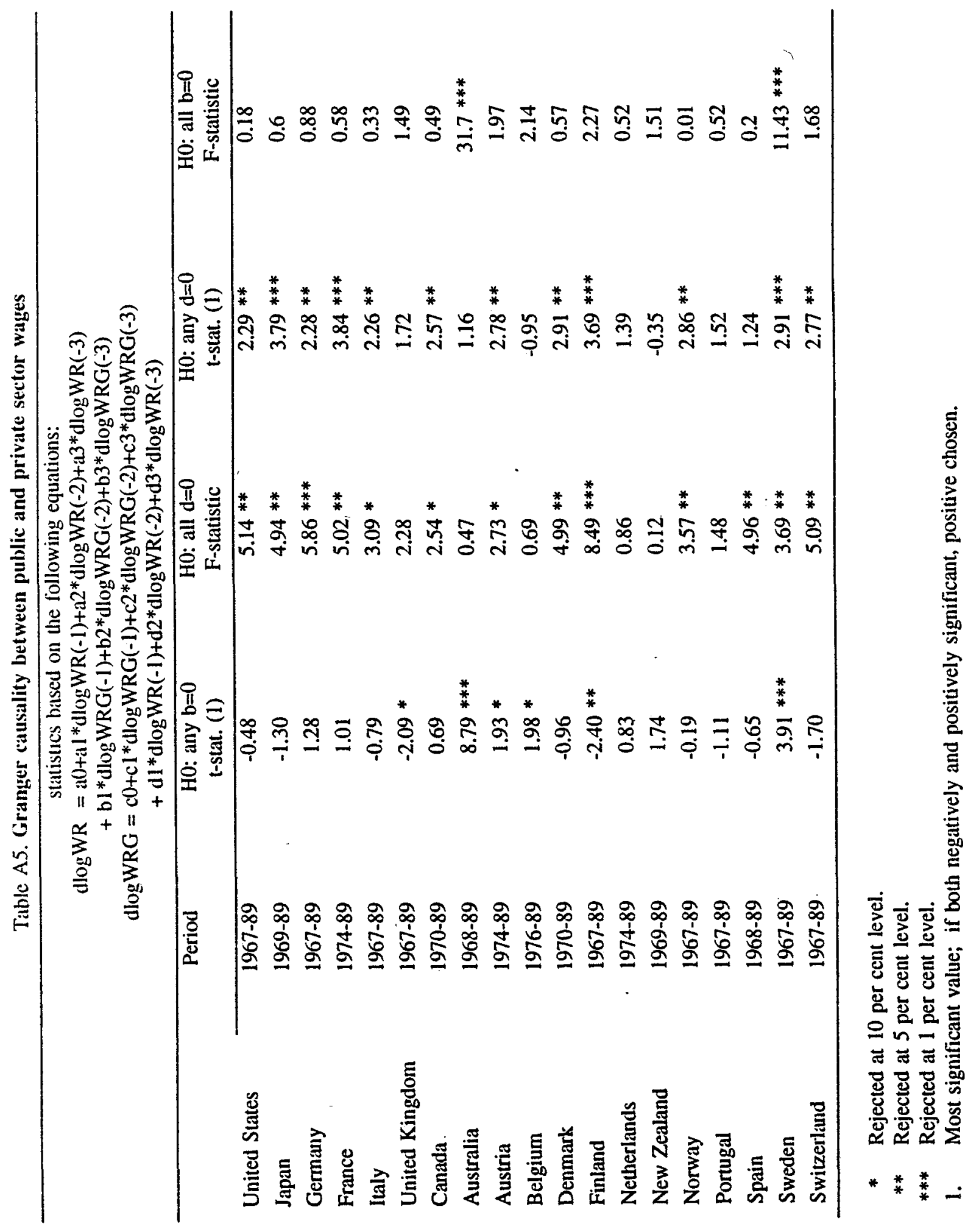


Table A6. Employment adjustment

Share of long-run employment response occurring in the first year in response to:

\begin{tabular}{|c|c|c|c|}
\hline & & \multirow{2}{*}{ of substitution } \\
\hline & Output change & Real wage change & \\
\hline United States & 60 & - & - \\
\hline Japan & 16 & -- & -- \\
\hline Germany & 52 & 56 & 0.48 \\
\hline France & 47 & $\cdots$ & - \\
\hline Italy & 26 & -- & $\cdots$ \\
\hline United Kingdom & 44 & 93 & 0.33 \\
\hline Canada & 66 & 71 & 0.39 \\
\hline Australia & 40 & 26 & 0.63 \\
\hline Austria & 35 & -- & -- \\
\hline Belgium & 55 & - & - \\
\hline Denmark & 65 & - & -- \\
\hline Finland & 52 & -- & -- \\
\hline Greece & -- & -- & $\cdots$ \\
\hline Iceland & - & - & 0.52 \\
\hline Ireland & 35 & 46 & 0.53 \\
\hline Netherlands & 45 & - & 0.29 \\
\hline New Zealand & 28 & -- & - \\
\hline Norway & 45 & - & - \\
\hline Portugal & -- & -- & -- \\
\hline Spain & 55 & 61 & 0.39 \\
\hline Sweden & 28 & - & -- \\
\hline Switzerland & 54 & $-\cdot$ & - \\
\hline Turkey & 24 & -- & -- \\
\hline
\end{tabular}

Note: The speeds of adjustment are based on estimated employment equations of the following form:

$$
\begin{array}{ll}
\Delta \log (\mathrm{L})= & \alpha_{0}+\alpha_{1} \Delta \log (\mathrm{L}(-1))+\alpha_{2} \cdot \log (\mathrm{Y})+\alpha_{3} \cdot \operatorname{\Delta log}(\mathrm{Y}(-1))+ \\
& \alpha_{1} \cdot \Delta \log (\mathrm{RW})+\alpha_{5} \cdot \log (\mathrm{Y}(-1) / \mathrm{L}(-1))+ \\
& \alpha_{6} \cdot \log (\mathrm{RW}(-1))+\alpha_{1} \cdot \mathrm{TIME}+\alpha_{6} \cdot \log (\mathrm{TMME}) \\
\text { where } \quad & \mathrm{L}=\text { employment, } \mathrm{Y}=\text { output, } \mathrm{RW}=\text { real product wage, all measured for the business sector. }
\end{array}
$$

The first column in the table contains the estimates of $\alpha_{2}$ while the second column corresponds to $\alpha_{4} /\left(\alpha_{d} / \alpha_{5}\right)$ and the third to $\alpha_{6} / \alpha_{5}$. Observations in the table are based on coefficients which were significant at least at the 10 per cent level. In the cases of the United States, Japan, France, Canada, Switzerland and Turkey, the estimated equation contained an extra term in the two-period lagged employment change. This was introduced to deal with problems of autocorrelation and in some cases reduced problems of structural stability. 
Figure A1. Okun curves and alternatlve measures of capacity utilization
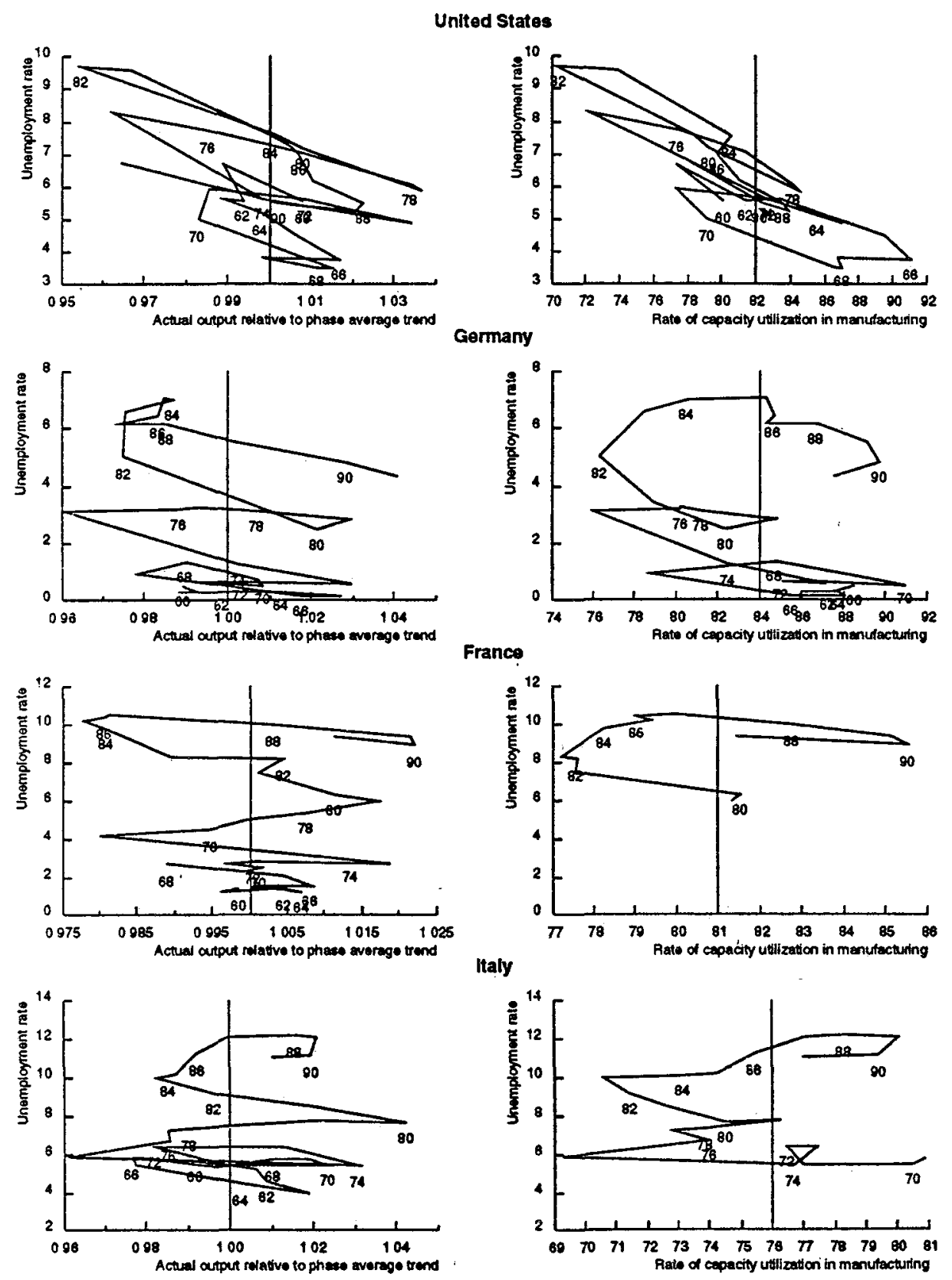
Figure A1 (continued)
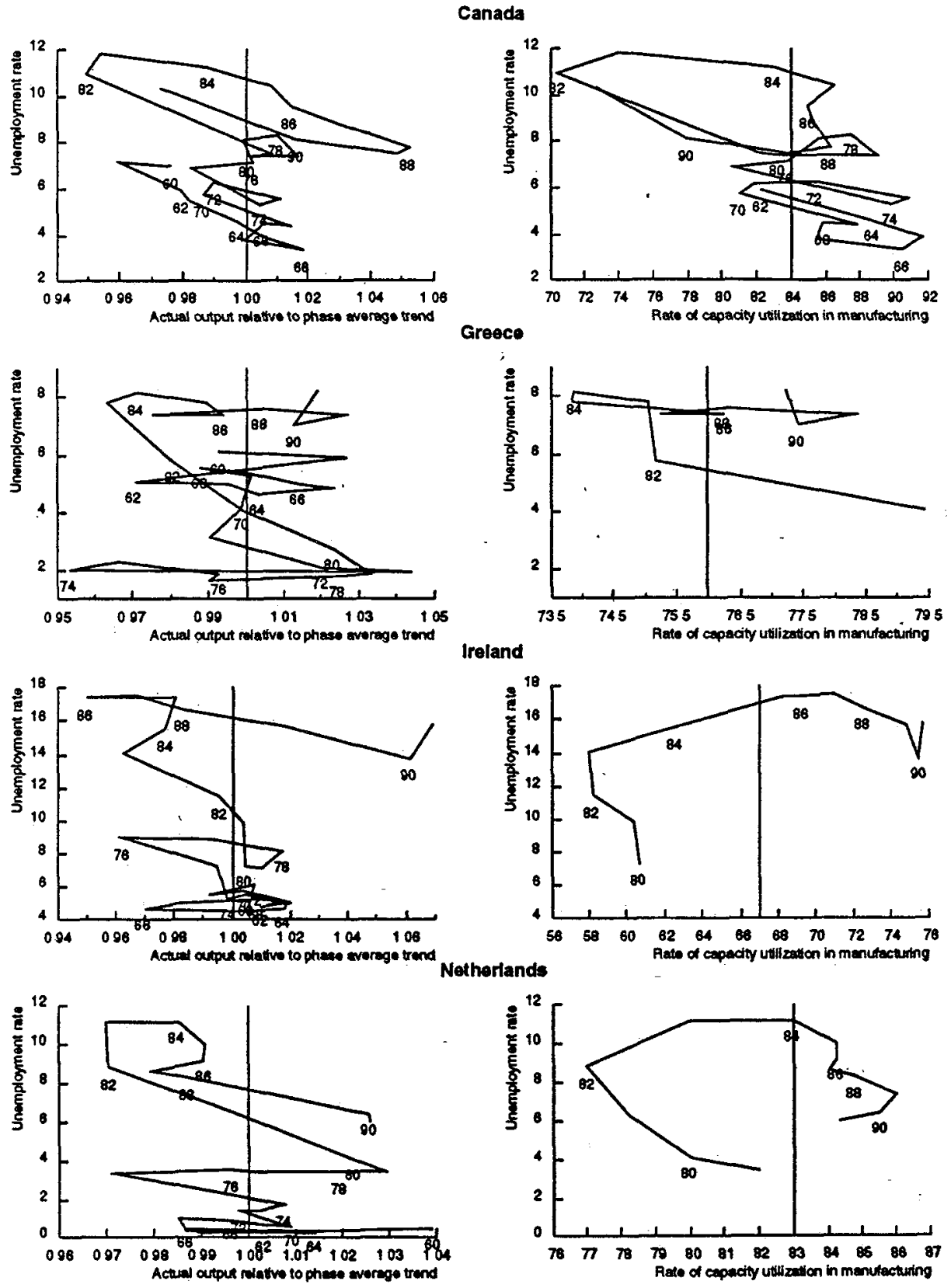
Figure A1 (continued)

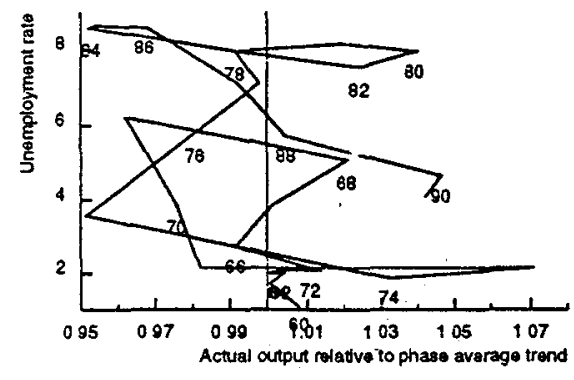

Portugal
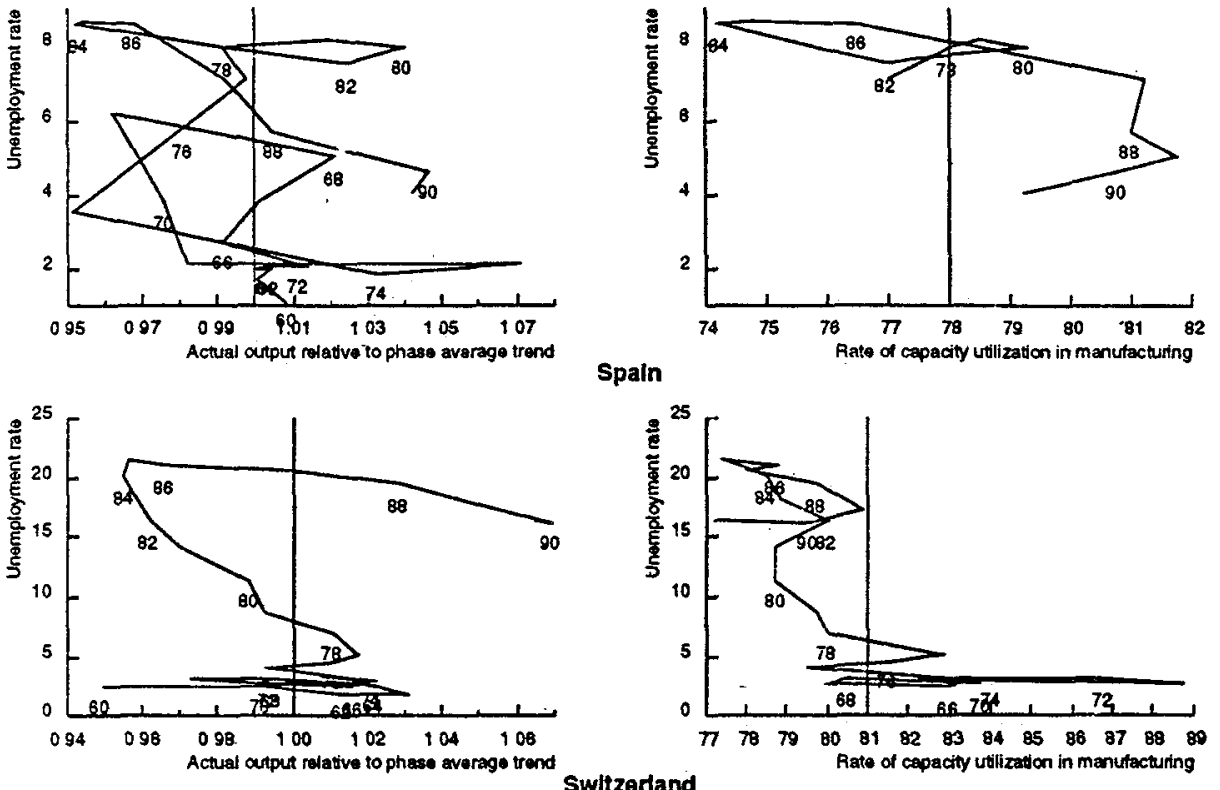

Spain
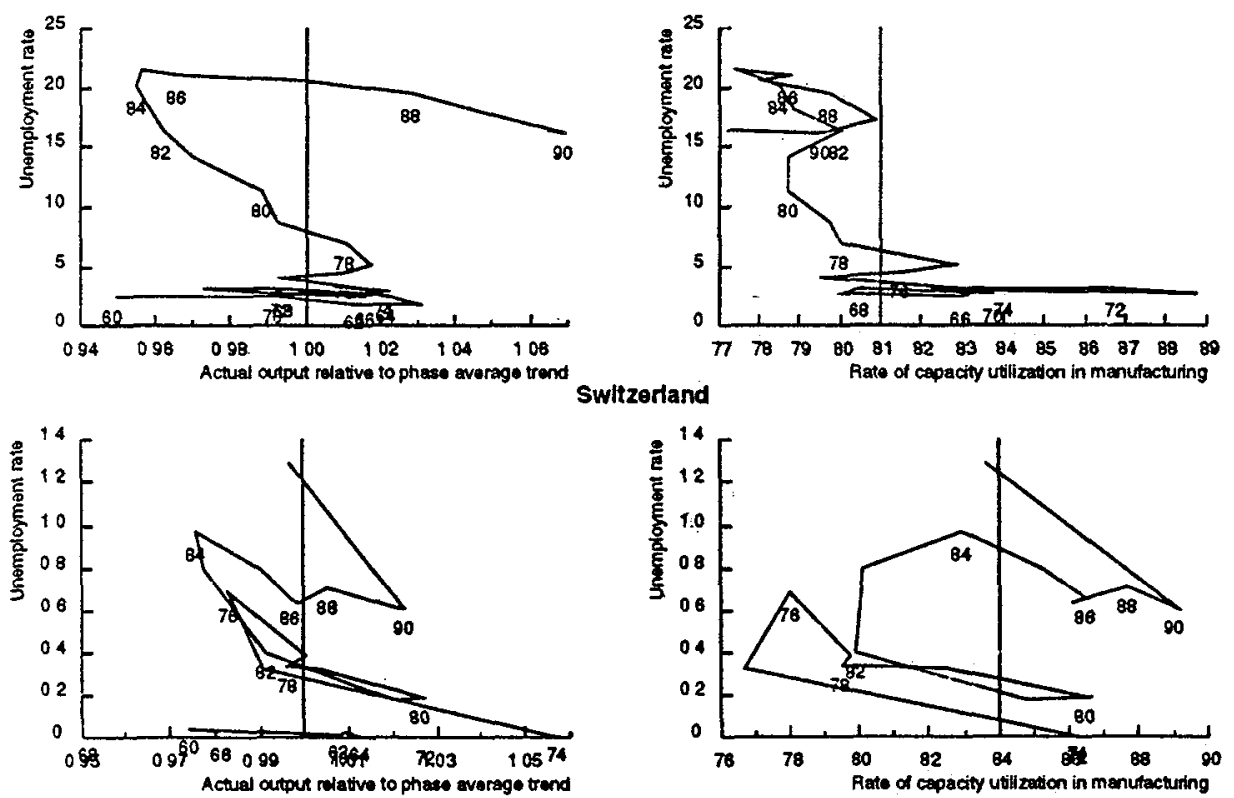


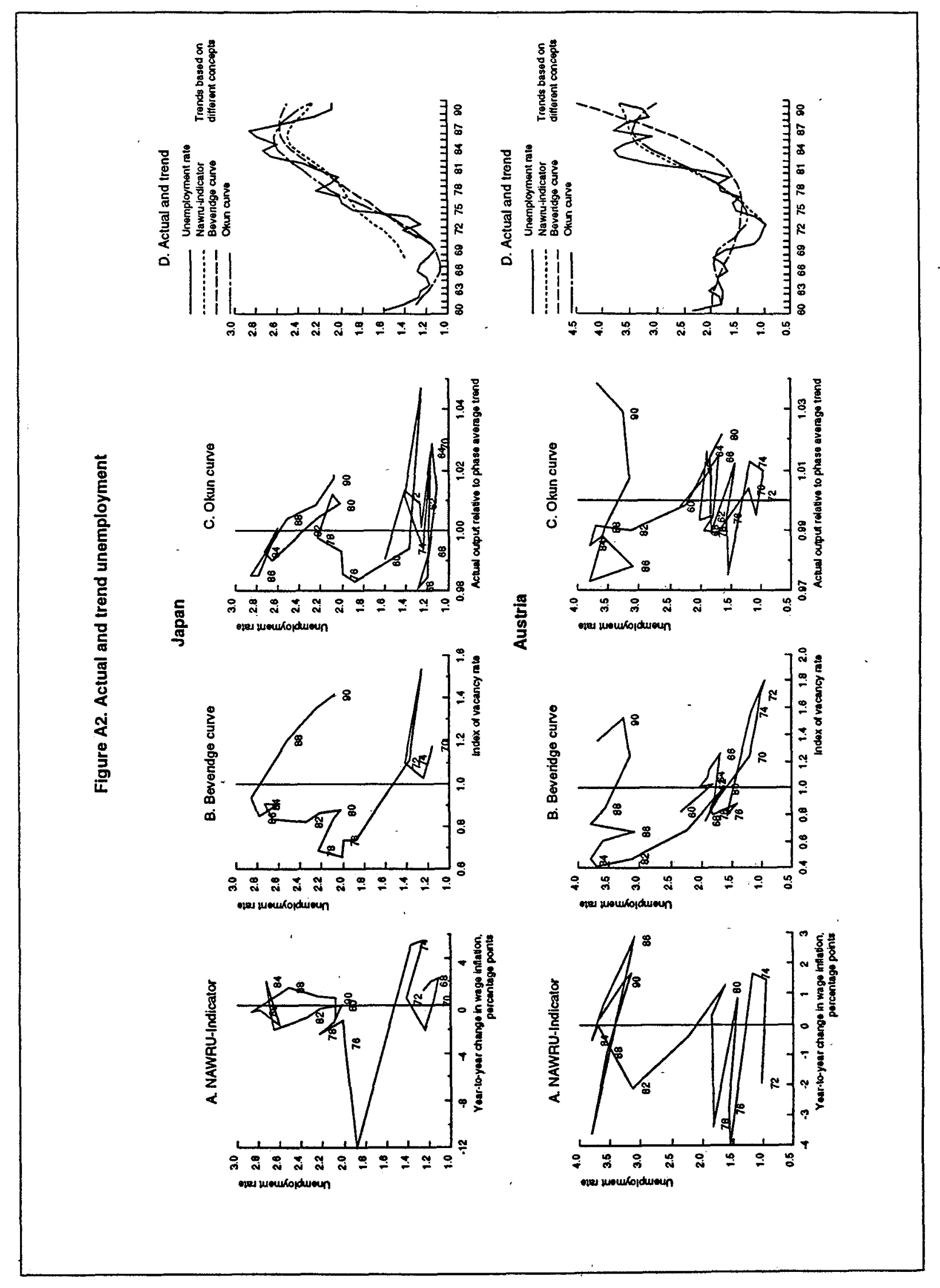




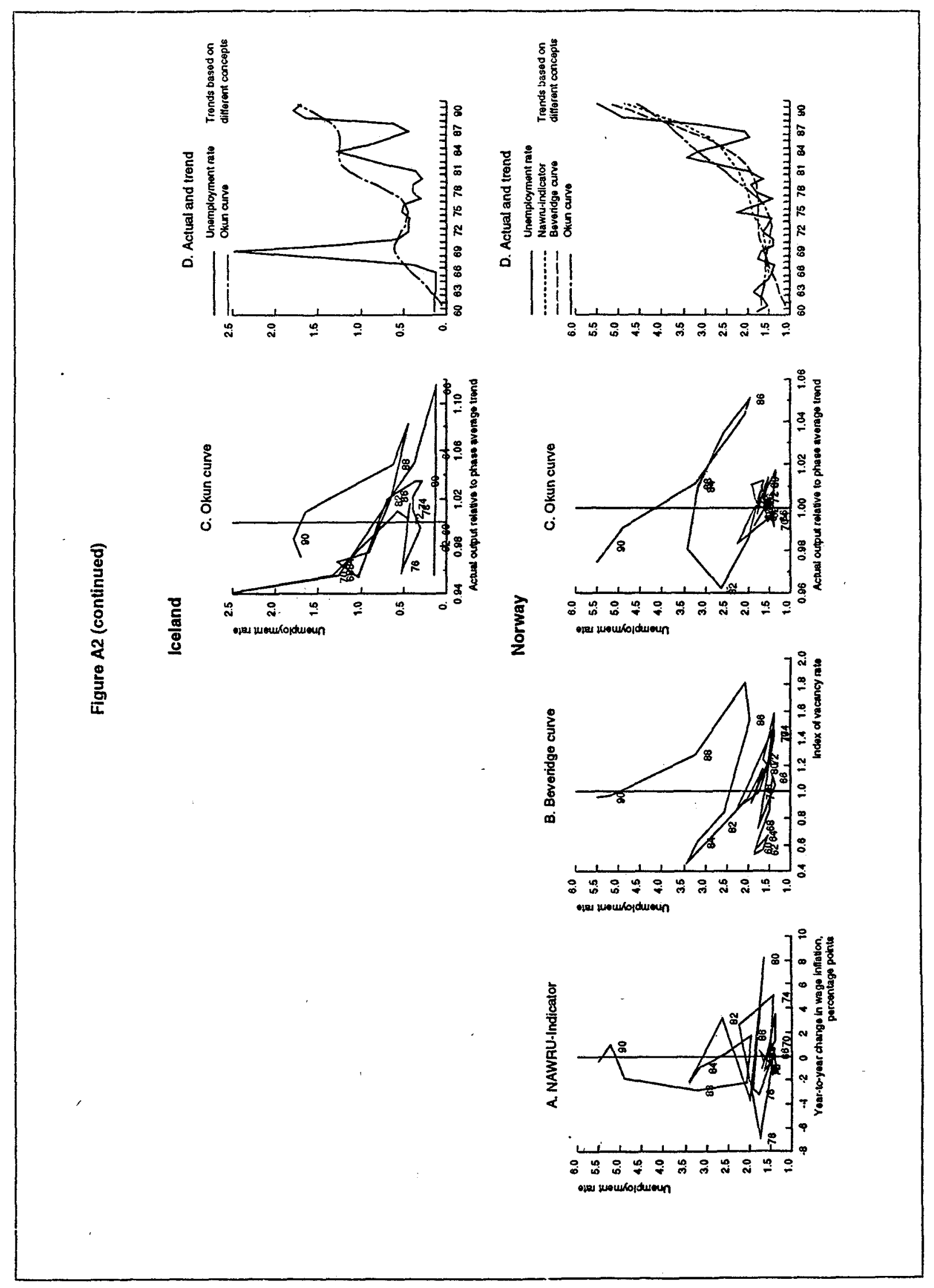




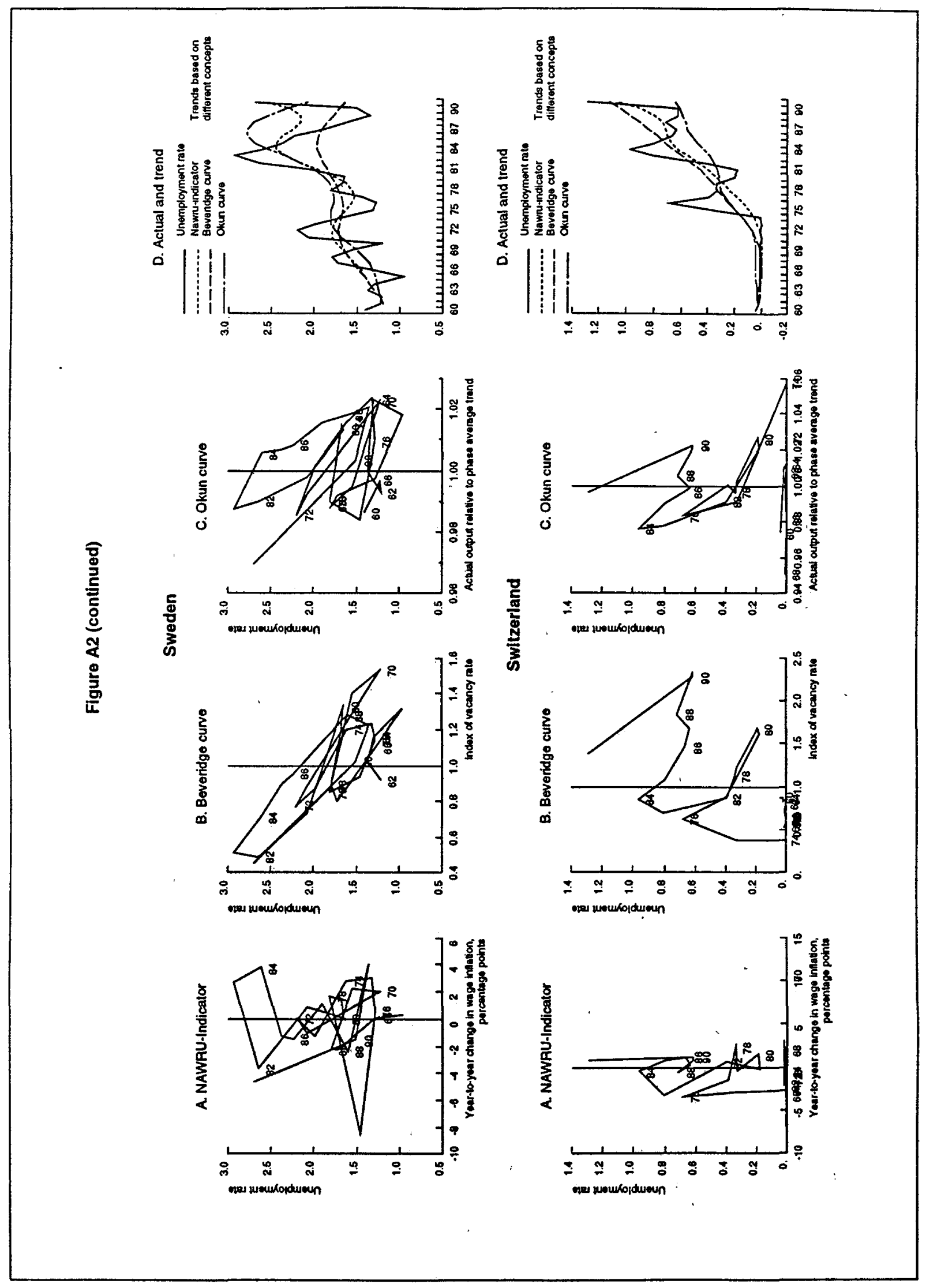




\section{References}

Abowd, J.M. and R.B. Freeman (1990), "The internationalisation of the U.S. labor market", NBER Working Paper series, No. 3321.

Abowd, J.M. and T. Lemieux (1991), "The effects of product market competition on collective bargaining agreements: The case of foreign competition in Canada", NBER Working Paper series, No. 3808.

Abraham, K.G. (1991), "Mismatch and labour mobility: some final remarks", in Schioppa (1991).

Abraham, K.G. and L.F. Katz (1986), "Cyclical unemployment: sectoral shifts or aggregate disturbances", Journal of Political Economy, 94/3.

Aghion, P. and P. Howitt (1991), "Unemployment -- A symptom of stagnation or a side-effect of growth?", European Economic Review, 35.

Albæk, K. and E.S. Madsen (1989), "Den solidariske lønpolitik og beskæftigelsen af lavtlønnede", Nationaløkonomisk Tidsskrift, Vol. 127/2.

Alogoskoufis, G.S. and A. Manning (1988), "Unemployment persistence", Economic Policy, October.

Andersen, P.S. (1992), "OECD countries experiences with disinflation", Reserve Bank conference on inflation and disinflation, Sydney.

Andersen, P.S. (1992a), "Taxes and labour market developments", Ministry of Finance, Copenhagen.

Atkinson, A.B.' and J. Micklewright (1991), "Unemployment compensation and labor 'ket transitions: a critical review", Journal of Economic Literature.

Attanasio, O.P. and F.P. Schioppa (1991), "Regional inequalities, migration and mismatch in : 1960-86", in Schioppa (1991).

Barro, R. (1988), "The persistence of unemployment", American Economic Review, Papers and proceedings.

Bazen, S. and J.P. Martin (1991), "The impact of the minimum wage on earnings and employment in France", OECD Economic Studies, No. 16.

Bean, C. (1992), "Identifying the causes of British unemployment", European Unemployment programme, Conference at Chelwood Gate.

Bean, C. (1992a), "European Unemployment: A survey", Centre for Economic Performance Discussion Paper, No. 71. 
Bentolila, S. and J.J. Dolado (1991), "Mismatch and internal migration in Spain, 1962-86", in Schioppa (1991).

Bentolila, S. and J.J. Dolado (1992), "Who are the insiders? Wage setting in Spanish Manufacturing firms", European Unemployment Programme, Conference at Chelwood Gate.

Björklund, A. and B. Holmlund (1986), "The economics of unemployment insurance: the case of Sweden", FIEF Working Paper, 24, Stockholm.

Bjørn, N.H. (1991), Persistent Effects of Early Unemployment -- The Case of Apprentices, Centre for Labour Economics, Aarhus School of Business.

Blanchard, O.J. and P. Diamond (1990), "The cyclical behaviour of the gross flows of U.S. workers", Brookings Papers on Economic Activity, 2.

Blanchard, O.J. and L.F. Katz (1992), "Regional evolutions", Brookings Papers on Economic Activity, 1.

Blanchard, O.J. and L.H. Summers (1988), "Beyond the natural rate hypothesis", American Economic Review, 78/2.

Bodo, G and P. Sestito (1991), Le Vie dello Sviluppo, Bologna: Societá Editrice In Molino.

Borjas, G.J., R.B. Freeman and L.F. Katz (1991), "On the labor market effects of immigration and trade", NBER Working Paper series, No. 3761.

Bound, J. and G. Johnson (1992), "Changes in the structure of wages in the 1980s: an evaluation of alternative explanations", American Economic Review, June.

Bruno, M. and J. Sachs (1985), The Economics of Worldwide Stagflation, Oxford.

Buechtemann, C.F., G. Rodgers and G. Standing (ed.) (1991), "Employment security and labour market behaviour: Interdisciplinary approaches and international evidence".

Burda, M. and C. Wyplosz (1990), "Gross labour market flows in Europe: some stylized facts", memo 90/51/EP, INSEAD, Fontainebleau.

Calmfors, L. (1993), "The extent of centralisation of wage bargaining and macroeconomic performance -- a survey", OECD Department of Economics Working Papers, (forthcoming).

Calmfors, L. and J. Driffill (1988), "Bargaining structure, corporation and macroeconomic performance", Economic Policy, Vol. 6.

Campbell, T.Y and P. Perron (1991), "Pitfalls and opportunities: what macroeconomists should know about unit roots", NBER.

Charette, M.F. and B. Kaufmann (1987), "Short-run variations in the natural rate of unemployment", Journal of Macroeconomics, Summer.

Christofides, L. and A. Oswald (1991), "Real wage determination and rent-sharing in collective bargaining agreements", Centre for Economic Performance Discussion Paper, No. 42. 
Clark, K. and L. Summers (1979), "Labor market dynamics and unemployment: a reconsideration", Brookings Papers on Economic Activity, 1.

Darby, J., J. Ireland and S. Wren-Lewis, "Interest rates, vintages and the natural rate", mimeo, International centre for macroeconomic modelling, University of Strathclyde.

Davis, S.J. (1992), "Cross-country patterns of change in relative wages", NBER Working Paper series, No. 4085.

Davis, S.J. and J. Haltiwanger (1990), "Gross job creation and destruction: microeconomic evidence and macroeconomic implications", NBER.

Drèze, J.H. and C.R. Bean (1990), Europe's Unemployment Problem, Cambridge, Mass.

ECin, P.-A. and B. Holmlund (1992), "The swedish wage structure: the rise and fall of solidarity wage policy", paper prepared for the NBER Conference on Differences and Changes in Wage Structures, Cambridge, Mass.

Edin P.-A. and B. Holmlund (1992a), "Wage behaviour and labor market programs in Sweden: evidence from micro data", European Unemployment Programme, Conference at Chelwood Gate.

Egebo, T. and A.S. Englander (1992), "Institutional commitments and policy credibility: A critical survey and empirical evidence from the ERM", OECD Economic Studies, No. 18.

Elmeskov, J. and K. Pichelmann (1993), "Unemployment and labour force participation -- trends and cycles", OECD Department of Economics Working Papers, No. 130.

Flanagan, R.J. (1988), "Unemployment as a hiring problem", OECD Economic Studies, No. 11.

Franz, W. (1991), "Match and mismatch on the German labour market", in Schioppa (1991).

Freeman, R. (1988), "Labour market institutions and economic performance", Economic Policy, April.

Glyn, A. and B. Rowthorn (1988), "West European unemployment: corporatism and structural change", American Economic Review, 78/2.

Groshen, E.L. and C. Drozdowski (1992), "The recent rise in the value of education: market forces at work", Federal Reserve bank of Cleveland Economic Commentary, August.

Grubb, W.N. and R.H. Wilson (1992), "Trends in wage and salary inequality, 1967-88", Monthly Labour Review, June.

Heylen, F. (1991), "Long-term unemployment in the OECD countries -- insiders, outsiders and labour market policy", paper for EALE Conference in Madrid.

Holmlund, B. (1991), "Unemployment persistence and insider-outsider forces in wage determination", OECD Department of Economics Working Papers, No. 92.

Holmlund, B. and H. Ohlsson (1992), "Wage linkages between private and public sectors in Sweden", Labour, 6(2). 
Holmlund, B. and J. Zetterberg (1991), "Insider effects in wage determination -- evidence from five countries", European Economic Review, 35.

Jackman, R., R. Layard and S. Savouri (1991), "Mismatch: a framework for thought", in Schioppa (1991).

Juhn, C., K.M. Murphy and R.H. Topel (1991), "Why has the natural rate of unemployment increased over time?", Brookings Papers on Economic Activity, 2.

Katz, L.F. and K.M. Murphy (1992), "Changes in relative wages, 1963-1987: supply and demand factors", Quarterly Joumal of Economics, February.

Katz, L.F., G.W. Loveman and D.G. Blanchflower (1993), "A comparison of changes in the structure of wages in four OECD countries", NBER Working Paper series, No. 4297.

Kostoris, F.P.S. (1991), "A cross-country analysis of the tax-push hypothesis", paper presented at the EALE conference in Madrid.

Kostoris, F.P.S. (1992), "Regional wage dynamics: the Italian case", European Unemployment Programme, Conference at Chelwood Gate.

Laxton, D. and R. Tetlow (1992), "A simple multivariate filter for the measurement of potential output", Bank of Canada Technical Report.

Layard, R., S. Nickell and R. Jackman (1991), Unemployment -- Macroeconomic Performance and the Labour Market, Oxford.

Lazear, E.P. (1990), "Job security provisions and employment", Quarterly. Journal of Economics, 105/3.

Leonard, J. and R. Schettkat (1991), "A comparison of job stability in Germany and the US", Labour.

Lilien, D.M. (1982), "Sectoral shifts and cyclical unemployment", Journal of Political Economy, 90/4.

Lindbeck, A. (1992), "Macroeconomic theory and the labour market", European Economic Review, 36.

Manning, A. (1992), "Productivity growth, wage setting and the equilibrium unemployment rate", Centre for Economic Performance Discussion Paper, No. 63.

Meyer-zu-Schlochtern, F.J.M. (1988), "An international sectoral data base for thirteen OECD countries", OECD Economics and Statistics Department Working Papers, No. 57.

Murphy, K.M. and F. Welch (1992), "The structure of wages", The Quarterly Journal of Economics, February.

Nickell, S., J. Vainomaki and S. Wadhwani (1992), "Wages, unions, insiders and product market power", Centre for Economic Performance Discussion Paper, No. 77.

OECD (1986), Employment Outlook, September.

OECD (1988), Employment Outlook, September.

OECD (1989), Employment Outlook, July. 
OECD (1989a), Economies in Transition -- Structural Adjustment in OECD Countries.

OECD (1990), Employment Outlook, July.

OECD (1990a), OECD Economic Surveys -- Italy.

OECD (1990b), OECD Economic Surveys -- Denmark.

OECD (1991), Employment Outlook, July.

OECD (1992), Employment Outlook, July.

OECD (1992a), Education at a Glance.

OECD (1992b), Structural Change and Industrial Performance -- A Seven Country Decomposition Study.

OECD (1993), OECD Economic Surveys -- Denmark.

OECD (1993a), Employment Outlook, July.

Pedersen, P.J. and N. Westergård-Nielsen (1993), "Unemployment: a review of the evidence from panel data", OECD Economics Studies, No. 20.

Phelps, E.S. (1992), "Foreign and domestic determinants of unemployment rates through real-interest and real-exchange rate channels", in Groupe International de politique économique de l'OFCE, La Désinflation compétitive, le mark et les politiques budgétaires en Europe.

Podgursky. M. (1992), "The industrial structure of job displacement, 1979-89", Monthly Labor Review, September.

Revenga, A.L. (1992), "Exporting jobs? the impact of import competition on employment and wages in U.S. manufacturing", The Quarterly Journal of Economics, February.

Risager, O. (1992), "Substitutionselasticiteten mellem faglærte og ufaglærte mænd i Danmark: Resultater of implikationer", in Ministry of Finance, Bilag til Finansredegørelse 92, Copenhagen.

Rowthorn, R.E. (1992), "Centralisation, employment and wage dispersion", The Economic Journal, 102, May.

Samson, L. (1990), "Sectoral shifts and aggregate unemployment: additional empirical evidence", Applied Economics, 22.

Schioppa, F.P. (ed.) (1991), Mismatch and Labour Mobility.

Schioppa, F.P. (1991a), "A cross-country comparison of sectoral mismatch in the 1980s", in Schioppa (1991).

Smith, N. (1991), "Labour supply, unemployment and taxes in Denmark", mimeo, University of Aarhus. 
Tease, W., A. Dean, J. Elmeskov and P. Höller (1991), "Real interest rate trends: the influence of saving, investment and other factors", OECD Economic Studies, No. 17.

van den Heuvel, K. (1992), "Minimumbeloningen in de Europese Gemeenschap", Onderzoeksmemorandum AEI, No. 2.

Verreydt, E and J. Waelbroeck (1982), "European Community protection against manufactured imports from developing countries: a case study in the political economy of protection", in J. Bhagwati (ed.), Import Competition and Response, University of Chicago Press:

Weithers, T.M. and E.J. Sullivan (1991), "Demographic effects on the natural rate of unemployment or baby booms and unemployment", Economics Letters, 37.

Williamson, O.E. (1992), "The economic analysis of institutions and organisations -- in general and with respect to country studies", mimeo, University of California at Berkeley.

Wood, A. (1991), "The factor content of North-South trade in manufactures reconsidered", Weltwirtschaftliches Archiv, Vol. $27 / 4$. 


\section{ECONOMICS DEPARTMENT}

\section{WORKING PAPERS}

A complete list of Working Papers is available on request.

131. Centralisation of Wage Bargaining and Macroeconomic Performance: A Survey (September 1993) Lars Calmfors

130. Unemployment and Labour Force Participation -- Trends and Cycles (June 1993) Jørgen Elmeskov and Karl Pichelmann

129. Trends and cycles in Labour Productivity in the Major OECD Countries (June 1993) Giuseppe Nicoletti and Lucrezia Reichlin

128. International Integration of Financial Markets and the Cost of Capital (March 1993) Mitsuhiro Fukao

127. The International Spillovers of Capital Income Taxation: An Applied General Equilibrium Analysis (January 1993) François Delorme, Lawrence H. Goulder and Philippe Thalmann

126. The Future of Capital Income Taxation in a Liberalised Financial Environment (January 1993) David Carey, Jean-Claude Chouraqui and Robert P. Hagemann

125. Global Effects of the European Carbon Tax

(December 1992) Giuseppe Nicoletti and Joaquim Oliveira Martins

124. The Chinese Economic Area: Economic Integration Without a Free Trade Agreement (July 1992) Randall Jones, Robert King and Michael Klein

123. New Issues: The OECD's Second Survey of the Macroeconomic Costs of Reducing $\mathrm{CO}_{2}$ Emissions (July 1992) Peter Hoeller, Andrew Dean and Masahiro Hajafuji

122. Costs of Reducing $\mathrm{CO}_{2}$ Emissions: Evidence from Six Global Models (July 1992) Andrew Dean and Peter Hoeller

121. Results for the OECD Comparative Modelling Project from the WHALLEY-WIGLE Model (July 1992) John Whalley (University of Western Ontario) and Randall Wigle (Wilfrid Laurier University)

120. OECD's Indicators of International Trade and Competitiveness (July 1992) Martine Durand, Jacques Simon and Colin Webb

119. Les indicateurs de compétitivité et de commerce internationaux de l'OCDE (July 1992) Martine Durand, Jacques Simon and Colin Webb

118. The Cost of Reducing $\mathrm{CO}_{2}$ Emissions: A comparison of Carbon Tax Curves with GREEN (July 1992) Joaquim Oliveira-Martins, Jean-Marc Burniaux, John P. Martin and Giuseppe Nicoletti

117. Adjustment under Fixed Exchange Rates : Application to the European Monetary Union (July 1992) A. Steven Englander and Thomas Egebo

116. GREEN: A Multi-sector, Multi-region, Dynamic General Equilibrium Model for Quantifying the Costs of Curbing $\mathrm{CO}_{2}$ Emissions: A Technical Manual (May 1992) Jean-Marc Burniaux, John P. Martin, Giuseppe Nicoletti and Joaquim Oliveira-Martins 
115. The Costs of Reducing $\mathrm{CO}_{2}$ Emissions: Evidence from Green

(May 1992) Jean-Marc Burniaux, John P. Martin, Giuseppe Nicoletti and Joaquim Oliveira-Martins

114. Carbon Taxes and $\mathrm{CO}_{2}$ Emissions Targets: Results from the IEA Model

(April 1992) E. Lakis Vouyoukas, IEA

113. Use of the Edmonds-Reilly Model to Model Energy-Related Greenhouse Gas Emissions

(April 1992) D.W. Barns, J.A. Edmonds and J.M. Reilly, Pacific Northwest Laboratory, Washington, D.C.

112. The Welfare Effects of Fossil Carbon Restrictions: Results from a Recursively Dynamic Trade Model (April 1992) Thomas Rutherford, University of Western Ontario

111. Global 2100: Alternative Scenarios for Reducing Carbon Emissions

(April 1992) Alan S. Manne, Stanford University

110. Energy Taxation and Price Distortions in Fossil Fuel Markets: Some Implications for Climate Change Policy

(April 1992) Peter Hoeller and Jonathan Coppel

109. The Information Content of Interest Rate Spreads Across Financial Systems (April 1992) Frank Browne and Warren Tease

108. Is there a future for capital income taxation? (March 1992) Jack M: Mintz

107. A "Credit Crunch"? The Recent Slowdown in Bank Lending and its Implications for Monetary Policy (March 1992) Paul Francis O'Brien and Frank Browne

106. Energy Prices, Taxes and Carbon Dioxide Emissions (July 1991) Peter Hoeller and Markku Wallin

105. Savings Trends and Measurement Issues (July 1991) Jeffrey Shafer, Jorgen Elmeskov and Warren Tease

104. GREEN - A Multi-Region Dynamic General Equilibrium Model for Quantifying the Costs of Curbing $\mathrm{CO}_{2}$ Emissions: A Technical Manual

(June 1991) J.M. Burniaux, J.P. Martin, G. Nicoletti, J. Oliveira-Martins

103. The Costs of Policies to Reduce Global Emissions of $\mathrm{CO}_{2}$ : Initial Simulation Results with GREEN (June 1991) J.M. Burniaux, J.P. Martin, G. Nicoletti, J. Oliveira-Martins

102. Patterns of Recoveries for the Major Seven OECD Countries (June 1991) Marco Mira d'Ercole

101. P-Star as an Indicator of Inflationary Pressure (March 1991) Peter Hoeller and Pierre Poret

100. Old Age Income Maintenance

(April 1991) Murray Petrie, Peter Sturm

99. The Measurement of Output and Factors of Production for the Business Sector in the 24 OECD Member Countries

(March 1991) Mark Keese, Gerard Salou, Pete Richardson

98. Macroeconomic Consequences of Financial Liberalisation: A Summary Report

(February 1991) Adrian Blundell-Wignall and Frank Browne 


GENERAL DISTRIBUTION

\section{ECONOMICS DEPARTMENT}

\section{WORKING PAPERS}

This series of Working Papers is designed to make available, to a wider readership, selected studies which the Department has prepared for use within OECD. Authorship is generally collective, but main individual authors are named. The Papers are generally available in their original language, English or French, with a summary in the other.

The views expressed in this paper are those of the authors, and do not necessarily reflect those of the OECD or of the governments of its Member countries.

Comment on the Papers is invited, and may be sent to OECD, Economics Department, 2 rue André Pascal, 75775 Paris Cedex 16, France. Additional copies of the Papers on a limited basis can be forwarded on request. 